\title{
NSP-reticulons : characterization and use for the detection of neuroendocrine differentiation in lung cancer
}

Citation for published version (APA):

Senden, N. H. M. (1995). NSP-reticulons : characterization and use for the detection of neuroendocrine differentiation in lung cancer. [Doctoral Thesis, Maastricht University]. Datawyse / Universitaire Pers Maastricht. https://doi.org/10.26481/dis.19951215ns

Document status and date:

Published: 01/01/1995

DOI:

10.26481/dis.19951215ns

Document Version:

Publisher's PDF, also known as Version of record

\section{Please check the document version of this publication:}

- A submitted manuscript is the version of the article upon submission and before peer-review. There can be important differences between the submitted version and the official published version of record.

People interested in the research are advised to contact the author for the final version of the publication, or visit the DOI to the publisher's website.

- The final author version and the galley proof are versions of the publication after peer review.

- The final published version features the final layout of the paper including the volume, issue and page numbers.

Link to publication

\footnotetext{
General rights rights.

- You may freely distribute the URL identifying the publication in the public portal. please follow below link for the End User Agreement:

www.umlib.nl/taverne-license

Take down policy

If you believe that this document breaches copyright please contact us at:

repository@maastrichtuniversity.nl

providing details and we will investigate your claim.
}

Copyright and moral rights for the publications made accessible in the public portal are retained by the authors and/or other copyright owners and it is a condition of accessing publications that users recognise and abide by the legal requirements associated with these

- Users may download and print one copy of any publication from the public portal for the purpose of private study or research.

- You may not further distribute the material or use it for any profit-making activity or commercial gain

If the publication is distributed under the terms of Article $25 \mathrm{fa}$ of the Dutch Copyright Act, indicated by the "Taverne" license above, 


\section{NSP-RETICULONS}

CHARACTERIZATION AND USE FOR THE DETECTION OF NEUROENDOCRINE DIFFERENTIATION IN LUNG CANCER 
Publication of this thesis was financially supported by:

University of Limburg

Centocor (USA)

DAKO A/S (Denmark)

(C) NHM Senden, Maastricht, 1995

CIP-DATA KONINKLUJKE BIBLIOTHEEK, DEN HAAG

Senden. Nicole Hubertuna Matra

NSP.reticalons : characterization and use for the detection of netroendocrine differentiation in hung cancer / Nicole Hubortina Maria Senden, - Maastricht

Universitabre Pers Mastriclnt. - Jll.

Thesis Rijksuniversiteit Limburg Massitricht, - With ref. With summary in Dutcht.

ISBN $90-5278-205-9$

Subject hesdings: NSP-reticulans / neuroendocrinc differentiation / lung cancer.

Cover illustration: Immunocytochemical localization of NSP-C to the endoplasmic reticulum 


\section{NSP-RETICULONS \\ CHARACTERIZATION AND USE FOR THE DETECTION OF NEUROENDOCRINE DIFFERENTIATION IN LUNG CANCER}

Proefschrift

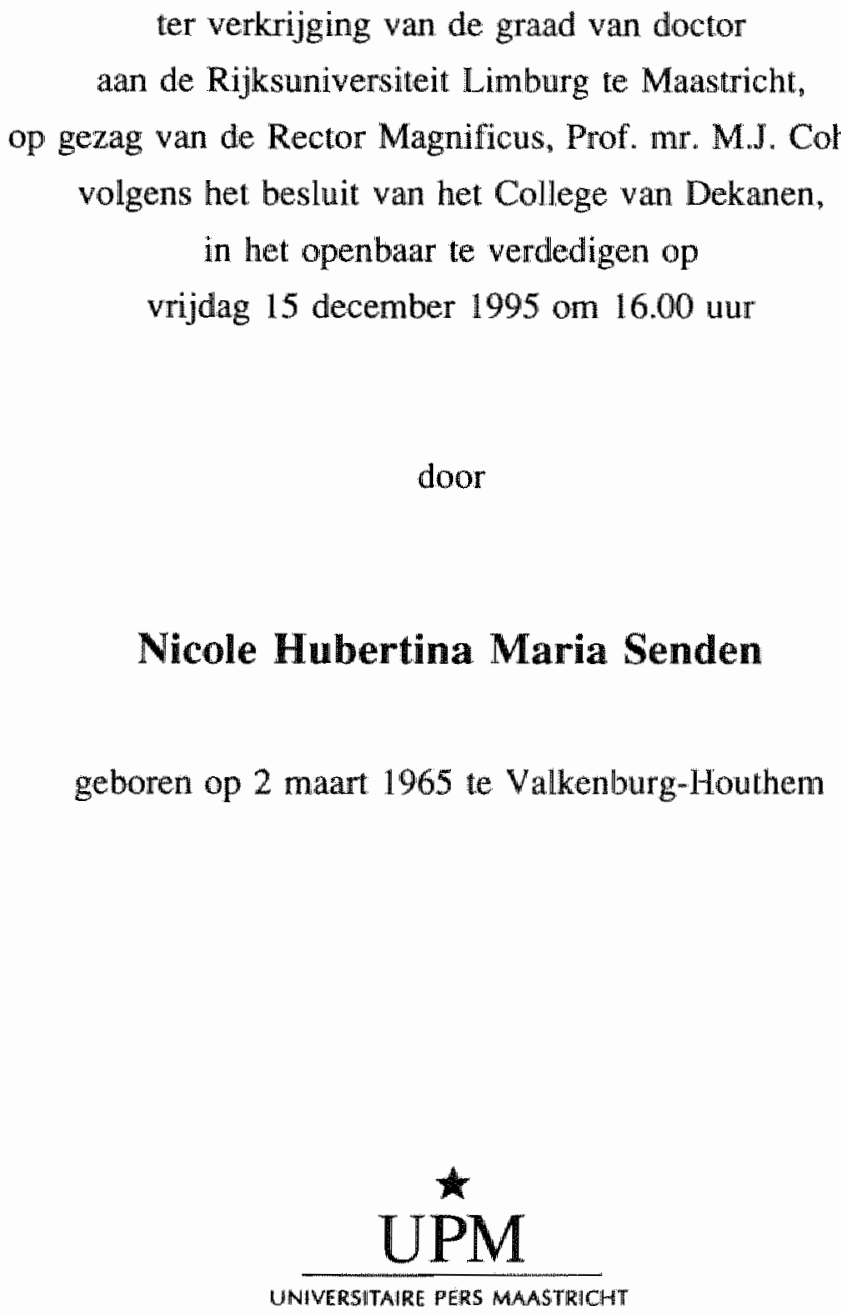




\section{Promotor:}

Prof. dr. F.C.S. Ramaekers

\section{Co-promotor:}

Dr. J.L.V. Broers

\section{Beoordelingscommissie:}

Prof. dr. E.F.M. Wouters (voorzitter)

Prof. dr. J.W. Arends

Prof. dr. F.T. Bosman (Erasmus Universiteit Rotterdam)

Prof. dr. H.F.P. Hillen

Dr. R.J.A.M. Michalides (Nederlands Kanker Instituut, Amsterdam)

The investigations described in this thesis were carried out at the Department of Molecular Cell Biology \& Genetics, University of Limburg, Maastricht, The Netherlands. Part of the research was performed at the Laboratory for Molecular Oncology, Center for Human Genetics, University of Leuven, Belgium. The project was financially supported by the Netherlands Cancer Foundation. 
To all of you who have contributed in any way.........thank you!

Ter herinnering aan oma voor pap en mam 



\section{CONTENTS}

List of abbreviations

General Introduction

Chapter 1

Cluster-10 lung cancer antibodies recognize NSPS, novel neuroendocrine proteins associated with membranes of the endoplasmic reticulum.

In J Cancer supplement 8: 84-88, 1994

\section{Chapter 2}

NSP-encoded reticulons, neuroendocrine proteins of a novel gene family associated with membranes of the endoplasmic reticulum.

$J$ Cell Sci 107: 2403-2416, 1994

Chapter 3

Subcellular localization and supramolecular organization of neuroendocrinespecific protein B (NSP-B) in small cell lung cancer.

Eur I Cell Biol 65: $341-353,1994$

\section{Chapter 4}

Neuroendocrine-specific protein C (NSP-C): subcellular localization and differential expression in relation to NSP-A.

Eur $J$ Cell Biol, in press, 1996

\section{Chapter 5}

NSP-encoded reticulons are neuroendocrine markers of a novel category in human lung cancer diagnosis.

Cancer Res 54: 4769-4776, 1994

\section{Chapter 6}

NSP-reticulons as independent markers for non-small cell lung cancer with neuroendocrine differentiation.

Submitted for publication

\section{Chapter 7}

A comparison of NSP-A and NSP-C with other neuroendocrine markers in neoplasms of the lung.

Submitted for publication

\section{Summary}

Samenvatting

Color illustrations 


\begin{tabular}{|c|c|}
\hline APUD & amine precursor uptake and decarboxylation \\
\hline Q-Gal & B-gatactosidase \\
\hline BSA & bowine serum albumin \\
\hline $\mathrm{CgA}$ & chromogranin A \\
\hline$C K-B B$ & brain isoenzyme of creatin kinase \\
\hline CK & cytokeratin \\
\hline $\mathrm{DCV}$ & dense core vesicle \\
\hline DDC & L-dopa decarboxylase \\
\hline ELISA & enzyme-linked immunosorbent assay \\
\hline EM & electron microscopy \\
\hline ER & endoplasmic reticulum \\
\hline FITC & fluorescein isothiocyanate \\
\hline GRP & gastrin-releasing peptide \\
\hline GST & glutathion Si-transferase \\
\hline $\mathbb{I F P}$ & intermediate filament protein \\
\hline $\operatorname{Ig}$ & irrmunoglobulin \\
\hline $\mathrm{kb}$ & kilobase \\
\hline kbp & kilobasepairs \\
\hline $\mathrm{kDa}$ & kiloDalton \\
\hline LCLC & large cell lung carcinoma \\
\hline mab & monocllonal antibody \\
\hline$M w$ & molecular weight \\
\hline NCAM & neural cell adhesion molecule \\
\hline $\mathrm{NE}$ & neuroendocrine \\
\hline NF & neurofilament \\
\hline NGS & normal goat serum \\
\hline non-SCLC & non-small cell lung cancer \\
\hline non-SCLC-NE & non-SCLC with neuroendocrine characteristics \\
\hline $\mathrm{NSE}$ & neuron-specific enolase \\
\hline PBS & phosphate buffered saline \\
\hline SCLC & small cell lung cancer \\
\hline $\mathrm{SCLC} \cdot \mathrm{C}$ & classic type SCLC \\
\hline SCLC - V & variant type SCLC \\
\hline SDS & sodium dodecyl sulphate \\
\hline SDS-PAGE & SDS-polyacrylamide gel electrophoresis \\
\hline Syn & synaptophysin \\
\hline SP-A & surfactant protein-A \\
\hline TRITC & tetramethylrhodamin isothiocyanate \\
\hline
\end{tabular}




\section{GENERAL INTRODUCTION}

\section{The diffuse neuroendocrine system}

The diffuse neuroendocrine (NE) system consists of a variety of NE cells, which can be identified by the presence of certain enzymes, peptides and amines, as well as secretory organelles, and which occur in many classical endocrine organs and in other tissues with endocrine features (see Table 1) [1]. These cells were already identified in the late 19th and early 20th century [2-5]. In 1938, Friedrich Feyrter described the existence of populations of endocrine cells in the epithelium of many organs, including the lung [6]. Historically, these cells of the diffuse NE system have been given different names, either according to their morphology (for example clear cell) [7], after the authors that described them (for instance Feyrter cell or Kultschitzky cell) $[8,9]$, according to their histochemical properties (e.g. argyrophil cell or chromaffin-type cell) $[10,11]$, or according to their content (e.g. small granule cell or dense-core granulated cell) $[12,13]$. Pearse [14-18] was the first to group these cells on the basis of their common morphological , functional and embryological characteristics. These common characteristics included the presence of dense-core (neurosecretory) vesicles and amine precursor uptake and decarboxylation (APUD) properties. Pearse [16] postulated that all cells of the diffuse NE system were of neural crest origin. Embryological data have, however, rejected the theory of neural crest origin for all NE cells $[19,20]$, leaving only cells of the adrenal medulla, extra-adrenal paraganglia, the myenteric plexus and sympathic ganglia, and probably also thyroid C-cells as neural crest derivatives [20-22]. The NE cells of the bronchopulmonary and gastrointestinal tract have now been shown to be most likely of endodermal origin [1].

\section{Neuroendocrine differentiation in the lung}

In addition to its major function in respiration, the lung also acts as an endocrine organ $[23,24]$. Solitary NE cells and neuroepithelial bodies are present in the fetal and adult lung, and are capable of producing a variety of biologically active substances. These include serotonin [25], gastrin-releasing peptide (GRP) or bombesin [26], the Cflanking peptide of pre-proGRP/bombesin [27], calcitonin [28] and calcitonin generelated peptide [29]. The endocrine aspects of the lung become often pronounced in disease situations. For instance, many neoplasms of the lung exhibit NE characteristics and are often accompanied by paraneoplastic endocrine syndromes [30].

\section{Lung Cancer}

The bronchial epithelium is the most common site for carcinogenesis in the lung. Four main histological types of lung carcinomas can be distinguished, i.e. small cell lung cancer (SCLC), squamous cell carcinoma, adenocarcinoma and large cell carcinoma [31], each with distinct biological characteristics. The latter three are collectively 
called non-SCLC. Major clinical and therapeutical differences exist between SCLC and non-SCLC. SCLC is more susceptible to chemotherapy, while for non-SCLC surgery is the major curative therapy. The NE neoplasms of the lung comprise a scalla of tumor types $[32,33]$, of which carcinoids and SCLC are considered to be the two ends of a spectrum; at one end carcinoid tumors with distinct NE features and good prognosis and at the other end the highly malignant SCLCs, with more restricted NE phenotypes. Between these, several intermediate tumor types exist in terms of NE characteristics and malignant behaviour. Several authors have proposed criteria for classification and nomenclature of these intermediate types, such as atypical carcinoid [34], welldifferentiated NE tumor [35], large-cell NE carcinoma [36], bronchopulmonary Kulchitzky carcinoma [37] and NE carcinoma [38]. A considerable fraction of lung tumors exhibits histologic heterogeneity, thus complicating diagnosis. From an oncodevelopmental viewpoint the observed heterogeneity implies that such bronchopulmonary malignancies may arise from pluripotent epithelial (stem) cells, still capable of diverging into a variety of phenotypes [39]. This suggestion is strengthened by electron microscopical studies which show that markers for NE-, adeno-, and/or squamous cell differentiation can be found within the same tumor cell $[40,41]$. In this respect, also the spectrum of bronchopulmonary tumors exhibiting NE differentiation has continued to extend in the literature, since many authors reported on the finding of NE markers, such as dense core vesicles, peptide/amine hormone production and immunocytochemical markers in histologically non-SCLC [42-50]. Whether the presence of NE features in these non-SCLC is of influence on the malignant behaviour and respons to chemotherapy, remains to be answered. Some studies have indeed have shown a worse prognosis and/or a significantly higher chemotherapy respons rate in the non-SCLCs with NE characteristics as compared to typical non-SCLC [51-57]. Other studies, however, have shown no correllation between the presence of NE differentiation and survival rates $[47,58]$.

\section{Markers of neuroendocrine differentiation in lung cancer}

A number of methods is available to demonstrate NE differentiation in pulmonary neoplasms. The detection of dense core vesicles using electron microscopy remains one of the most definitive methods for identifying NE cells. Their presence in histologically non-SCLC is usually a strong indicator for NE differentiation [45], although such vesicles can be very scanty in poorly differentiated pulmonary tumors [43], can be confused with other cytoplasmic organelles and are even detected in a small number of non-NE tumors [59]. Histochemical stauning methods, that are related to the presence of dense core granules in the cell, include the argyrophyl (or Grimelius) technique [60], based on staining of components of dense core vesicles, responsible for storage and handling of amines [61], and the argentafin reaction [62] reflecting the presence of serotonin [63]. Both techniques lack, however, sensitivity and specificity in detecting NE cell types [1], and the argyrophyl reaction is not very useful in poorly differentiated neoplasms and small cell carcinoma because of the limited number of dense core vesicles present in such tumors [43].

Enzyme(cyto)chemical procedures frequently used include those for the detection of Ldopa decarboxylase (DDC), which is the key enzyme in amine production of NE cells. High levels of DDC-activity have been found in carcinoids, SCLC and in a subgroup 
of non-SCLC, but in general not in typical non-SCLC solid tumors and cell lines derived therefrom $[43,64]$. However, DDC-activity can also be found in non-NE tissues and tumors $[43,65]$. Furthermore, increased serum levels of the brain isoenzyme of creatine kinase (CK-BB) have been found in patients with SCLC and in SCLC cell lines [66-68]. Although CK-BB has little diagnostic value due to its lack of sensitivity and specificity [69], some studies indicate that CK-BB isoenzymes may provide useful prognostic information in patients with SCLC with extensive disease $[67,70]$. In recent years these assays are supplemented with immunocytochemical methods. The availability of (monoclonal) antibodies for the identification of markers of NE differentiation has facilitated the recognition of NE features in tissues. The antibodies to NE markers can be divided into two subgroups, i.e. those recognizing specific peptides or amine products, and those recognizing other features shared by all cells of the diffuse NE system (general markers). An overview of the expression of specific (hormone) peptides and amines in NE tissues and their tumors is presented in Table 1. Antibodies to specific NE markers, that have been succesfully applied in normal or neoplastic lung, include those to GRP, calcitonin, calcitonin gene-related peptide and serotonin, as well as markers to substances that are ectopically produced in lung tumors, such as adrenocorticotropic hormone, antidiuretic hormone, B-endorphin, somatostatin, vasoactive intestinal polypeptide and growth hormone. General markers include components of secretory vesicles, membrane proteins or cytoplasmic enzymes and are widely used in the immunocytochemical detection of NE differentiation. The markers applied in this study are:

Neuron-specific enolase (NSE): NSE, also known as gamma-enolase, is the most acidic isoform of the glycolytic enzyme enolase. The reactivity of antibodies to this constituent of NE cell types does not depend on the presence of neurosecretory vesicles. Originally, it has been reported to be a specific marker for nervous tissue, as well as normal and neoplastic cells of the diffuse NE system [71-74]. However, later studies $[75,76]$ demonstrated a low specificity of NSE as neuronal and NE marker, since it could be found also in several other types of tissue, including smooth muscle, myoepithelial cells, renal tubular cells, lymphocytes, bronchial epithelium, and type II alveolar lining cells. While antibodies to NSE are claimed to be useful in lung cancer diagnosis because of their high sensitivity for NE differentiation $[44,73,74,77]$ their specificity is so low $[44,74]$, that they should only be used in combination with other markers. Elevated serum levels of NSE have been found in patients with SCLC [78,79] and correlated well with tumor burden [80]. Serum NSE levels have proven useful in monitoring the clinical course of patients with SCLC since enzyme levels tend to decrease with treatment response and to elevate in case of relapse $178-80$; for conflicting data see 81 ].

Neural cell adhesion molecule (NCAM): NCAM comprises a family of closely related sialoglycoproteins, which are involved in cell-cell interactions or cell-matrix adhesion [82-84]. Antibodies to NCAM were grouped as cluster-1 by the International Workshops on Lung Tumor and Differentiation Antigens [85-87]. The tissue distribution of NCAM is in general confined to neural and NE tissues, such as central and peripheral nerve tissue or pancreatic islet cells and to neural and NE malignancies, such as SCLCs and neuroblastomas $[46,55,85,88,89]$. However, expression of NCAM 
has also been found in non-NE cells, such as Leydig cells of testis, follicular cells of the thyroid and smooth muscle cells $[85,89,90]$. Moreover, some authors dispute the specificity of NCAM, since it has been detected in cells lacking dense core vesicles [55]. In lung cancers, NCAM can be detected in carcinoids, SCLC and in a subset of non-SCLC and not in non-SCLC $[50,51,89,90]$.

Leu-7: The Leu-7 antigen is a glycoprotein present on natural killer cells, but also found in the nervous system and in the diffuse NE system [91]. Epitopes, similar to those detected in Leu-7 were recognized in myelin-associated glycoprotein [92], and in a dense core vesicle matrix constituent [93]. For the detection of NE lung tumors it can be useful, because of its specific reactivity with carcinoids and a considerable percentage of SCLC $[38,44,94,95]$. In non-SCLC it has been reported in a fraction of cases ranging from 10 to $30 \%[48,49,52]$.

Chromogramins/secretogranins: The chromogranins/secretogranins are a family of three acidic proteins of various sizes that are located in the soluble fraction of dense-core vesicles in neural and NE cell types [96]. They have been subdivided into chromogranin A and B (identical to secretogranin I) and chromogranin C (identical to secretogranin II). The function of these proteins is still unknown, although it has been suggested that they are involved in packaging and/or processing of certain peptide hormones and neuropeptides [97], play a role in binding intragranular calcium or may serve as hormone precursors $[98,99]$. The antibodies to chromogranin A are very specific for NE differentiation, but their immunoreactivity is dependent on neurosecretory vesicle density. Carcinoids of the lung usually stain strongly for chromogranin $A$, while SCLC with sometimes sparse neurosecretory granules, show infrequent immunostaining with antibodies to this constituent $[38,44,48,49,74,100]$. In a small proportion of histologically non-SCLC the presence of chromogranin A is detected $[44,48,49,74]$. In lung cancer cell lines chromogranin $A$ is detected in cases with high dense core vesicle concentrations and is therefore generally not found in variant SCLC cell lines [64].

Synaptophysin: Synaptophysin is an integral membrane protein of the small, electrontranslucent, neurosecretory vesicles of neural and NE cells [96]. It is a possible candidate for a fusion pore protein, neccesary for the rapid release of neurotransmitters [101]. Like chromogranin A, antibodies to synaptophysin are very specific in detecting $\mathrm{NE}$ differentiation in the lung. Immunoreactivity has been found by some authors across the whole spectrum of NE neoplasm [102,103], while others describe a more restricted occurrence in NE tumors [38]. Synaptophysin is expressed in most but not all classic and variant SCLC cell lines [64].

Neurofilament proteins: The three mammalian neurofilament proteins (approximate molecular weights 68,160 and $200 \mathrm{kDa}$ ) are members of the intermediate filament protein family and to a large extent specifically expressed in neuronal cells $[104,105]$. However, neurofilament antibodies have been found to be reactive with a range of NE tumors next to their positivity in neural neoplasms. Lung carcinoids can express neurofilaments next to cytokeratins [106], while in SCLC, only a subset of the cases express these proteins $[50,107]$. Also in SCLC cell lines neurofilaments are observed 
to a certain extent, with variant SCLC cell lines exhibiting the most pronounced expression $[108,109]$, while only sporadic expression was found in non-SCLC cell lines [108]. In non-SCLC tumors, especially in poorly differentiated squamous cell carcinomas and adenocarcinomas, neurofilaments can be occassionally observed $[50,110]$.

Since most markers used for the detection of NE differentiation exhibit either a poor specificity or a restricted sensitivity the use of a panel of markers for the diagnosis of NE tumors is advised [33,111]. Also the search for new markers continues in an attempt to find better indicators for the NE differentiation pathway.

\section{SCOPE OF THIS THESIS}

In our search of additional markers for NE differentiation, we have concentrated on the protein products of the recently identified neuroendocrine-specific protein (NSP)gene. The studies described in this thesis aim at a further characterization of the protein products of the NSP-gene, known to produce three transcripts [112]. The expression of this gene, giving rise to NSP-A, NSP-B and NSP-C, is found to be mainly restricted to neural and NE tissues and cells. The tissue distribution and subcellular localization of this family of NE-related constituents was examined.

After having defined their cell biological properties, the validity of NSP-A and NSP-C as NE markers in lung cancer was established by comparing their expression to that of conventional NE markers. For this purpose solid lung cancer specimens, as well as lung cancer cell lines were used. 
Table 1.

Tissues and neoplasms of the diffuse neuroendocrine system

\begin{tabular}{|c|c|c|}
\hline Tissues/cells & Neoplasms & Hormones and amines \\
\hline adrenal medulla & $\begin{array}{l}\text { pheochromocytoma } \\
\text { neuroblastoma } \\
\text { ganglioneuroma }\end{array}$ & $\begin{array}{l}\text { enkephalins, catecholamines, VIP, } \\
\text { somatostatin }\end{array}$ \\
\hline bronchopulmonary tree & neuroendocrine tumor & $\begin{array}{l}\text { GRP, ACTH, endorphin, calcitonin, } \\
\text { catecholamines, serotonin }\end{array}$ \\
\hline gastrolintestinal tract & $\begin{array}{l}\text { neuroendocrine adenoma } \\
\text { and carcinoma including } \\
\text { carcinoid }\end{array}$ & $\begin{array}{l}\text { gastrin, GRP, VIP, secretin, entero- } \\
\text { glucagon, PP, serotonin, catecholami- } \\
\text { nes, cholecystokinin, insulin, glucagon, } \\
\text { somatostatin }\end{array}$ \\
\hline adenohypophysis & $\begin{array}{l}\text { adenoma } \\
\text { carcinoma }\end{array}$ & $\begin{array}{l}\text { ACTH, GH, FSH, LH, PRL, TSH, } \\
\text { B-endorphin, calcitonin, catechola- } \\
\text { mines, MSH }\end{array}$ \\
\hline hypothalamus & hamartoma & $\begin{array}{l}\text { anterior pituitary releasing hormones, } \\
\text { vasopressin, oxytocin, dopamine }\end{array}$ \\
\hline melanocytes & melanoma & miscellaneous peptides, amines \\
\hline Merkel cells of skin & $\begin{array}{l}\text { neuroendocrine (Merkel } \\
\text { celly or trabecular } \\
\text { carcinoma }\end{array}$ & calcitonin, catecholamines, PP, VIP \\
\hline pancreatic islets & $\begin{array}{l}\text { adenoma } \\
\text { carcinoma }\end{array}$ & $\begin{array}{l}\text { insulin, PP, glucagon, VIP, gastrin, } \\
\text { catecholamines, serotonin, somatostatin }\end{array}$ \\
\hline paraganglion & paraganglioma & enkephalin, catecholamines, VIP \\
\hline parathyroid cells & adenoma and carcinoma & parathyroid hormone, catecholamines \\
\hline thyroid $C$ cell & medullary thyroid carcinoma & $\begin{array}{l}\text { calcitonin, somatostatio, ACTH, } \\
\text { CGRP, catecholamines }\end{array}$ \\
\hline $\begin{array}{l}\text { miscellaneous neuroendocrine } \\
\text { cells in breast, cervix, } \\
\text { kidney, larynx, ovary, } \\
\text { paranasal simus, prostate, } \\
\text { testis, thymus }\end{array}$ & $\begin{array}{l}\text { neuroendocrine adenoma, } \\
\text { carcinoma and mixed tumors }\end{array}$ & $\begin{array}{l}\text { miscellaneous peptides, serotonin, } \\
\text { catecholamines }\end{array}$ \\
\hline
\end{tabular}

"Abbreviations: VIP, vasoactive intestinal polypeptide; GRP, gastrin-releasing peptide; ACTH, adrenocorticotropin; PP, pancreatic polypeptide; GH, growth hormone; FSH, follicle-stimulating hormone; LH, luteinizing hormone; PRL, prolactin; TSH, thytoid stimulating hormone; MSH, melanocyte-stimulating hormone; CGRP, calcitonin gene-related peptide.

Adapted from R.V. Lloyd, Endocrine Pathology, Springer Verlag, New York, 1990. 


\section{REFERENCES}

1. Lloyd RV. Endocrine Pathology. Springer Verlag, New York, 1990

2. Heidenhain R. Untersuchungen über den Bau der Labdrüsen. Arch Mikrosk Anat 6 : $368-406,1870$.

3. Kultschitzky N. Zur frage über den bau des darmkanals. Arch Mikrosk Anat 49: 7-35, 1897.

4. Masson P. La glande endocrine de l'intestin chez l'homme. CR Acad Sci (Paris) 158: 59.61, 1914.

5. Hamperl H. Was sind argentaffine zellen? Virchows Arch Pathol Anat 286: 811-833, 1932.

6. Feyrter F. Uber diffuse endokrine epitheliale Organe. JA Barth, Leipzig, 1938.

7. Fröhlich $\mathbf{F}$. Die Helle Zelle der Bronchialschleimhaut und ihre Beziehungen zum Problem der Chemoreceptoren. Frankfurter Z Pathol 60:517-559, 1949.

8. Moosavi H, Smith P, Heath D. The Feyrter cell in hypoxia. Thorax 28: 729-741, 1973.

9. Bensch KG, Gordon GB, Miller LR. Studies on the bronchial counterpart of the Kultschitzky (argentaffin) cell and innervation of bronchial glands. J Ultrastruc Res 12:668-686, 1965.

10. Lauweryns JM, Peuskens JC. Argyrophil (kinin and amine producing?) cells in human infant airway epithelium. Life Sci 8: 577-585, 1969.

11. Basset F, Poirier J, Le Crom M, Turiaf J. Etude ultrastructurale de l'epithelium bronchiolaire humaine. Z Zellforsch Mikroskop Anat 116:425-442, 1971 .

12. MCDowell EM, Barrett LA, Trump BF, Observations on small granule cells in adult human bronchiall epithelium and in carcinoid and oat cell tumours. Lab Invest 34: 202-206, 1976.

13. Jeffery PK, Corrin B. Structural analysis of the respiratory tract. In: Immunology of the lung and upper respiratory tract. J. Bienenstock (ed), Mcgraw Hill, New York, pp 1-27, 1984.

14. Pearse AGE. Common cytochemical properties of cells producing polypeptide hormones with particular reference to calcitonin and the thyroid $\mathrm{C}$ cells. Vet Rec 79: 587-590, 1966.

15. Pearse AGE. Common eytochemical and ultrastructural characteristics of cells producing polypeptide hormones (The APUD series) and their relevance to thyroid and ultimobranchial $C$ cells and calcitonin. Proc R Soc Lond Ser B Biol Sci 170: 71-80, 1968.

16. Pearse AGE. The cytochemistry and ultrastructure of polypeptide hormone-producing cells of the APUD series and the embryologic, physiologic and pathologic implications of the concept. J Histochem Cytochem 17: 303-313, 1969.

17. Pearse AGE, Takor Takor T. Neuroendocrine embryology and the APUD concept. Clin Endocrinol suppl 5: 229-244, 1976.

18. Pearse AGE, Polak J. The diffuse neuroendocrine system and the APUD concept. In: Gut Hormones. SR Bloom (ed), Churchill Livingstone, Edinburgh, pp 33-39, 1978.

19. Fontaine J, Le Douarin NM. Analysis of endoderm formation in the avian blastoderm by the use of quaillochick chimeras. J Embryol Exp Morphol 41: 209-222, 1978.

20. Le Douarin NM. The neural crest. Cambridge University Press, Cambridge, England, 1982.

21. Le Douarin NM, Teillet MA. The migration of neural crest cells to the wall of the digestive tract in the avian embryo. J Embryol Exp Morphol 30: 31-48, 1973

22. Holm R, Sobrinho-Simoes M, Nesland JM, Sambade C, Johannessen JV. Medullary thyroid carcinoma with thyroglobulin immunoreactivity. A special entity? Lab Invest 57: 258-268, 1987.

23. Gosney JR. Pulmonary endocrine pathology. Butterworth-Heinermann, Oxford, 1992.

24. Ryan JW. Processing of endogeneous polypeptides by the lung. Ann Rev Physiol 44: 269-274, 1982.

25. Lauweryns JM, de Bock $V$, Verhofstad AAJ, Steinbusch HWM. Immunohistochenical localization of serotonin in intrapumonary neuroepithelial bodies. Cell Tissue Res 226:215-223, 1982.

26. Wharton J, Polak JM, Bloom SR, Ghatei MA, Solcia E, Brown MR, Pearse AG. Bombesin like immunoreactivity in the lung. Nature 273: 769-770, 1978.

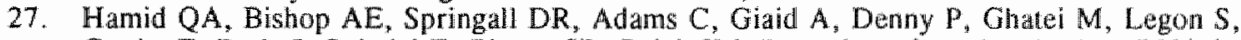

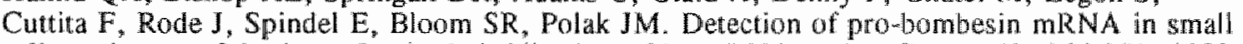
cell carcinoma of the lung: In situ hybridisation with a CRNA probe. Cancer 63: 266-271, 1989.

28. Becker KL, Monaghan KG, Silva OL. Immunocytochemical localization of calcitonin in Kulchitsky cells of human lung. Arch Pathol Lab Med 104: 196-198, 1980.

29. Johnson DE, Wobken JD. Calcitonin gene-related peptide immunoreactiwity in airway epithelial cells of the human fetus and infant. Cell Tissue Res 250:579-583, 1987.

30. Greco FA, Hainsworth $J$, Sismani A, Richardson R, Hande KR, Oldham RK. Hormone production and paraneoplastic syndromes. In: Small Cell Lung Cancer. FA Greco, RK Oldham and PA Bunn (eds), Grune \& Stratton, New York, pp 117-223, 1981. 
31. The World Healh Organization histological typing of Iung tumours. Am J Clin Pathol 77 : 123-136, 1982,

32. Sheppard MN. Neuroendocrine tumours of the lung. In: Diagnostic histopathology of neuroendacrine tumours. IM Polak (ed), Churchill Livingstone, Edinburgh, pp 151-165, 1993.

33. Linnola RI, Aisner SC. Pathology of lang cancer: an exercise in classification. In: Lung Cancer. BE Johnson and DH Johnson (eds), Wiley-Liss, New York, pp 73-95, 1995.

34. Arrigoni MG, Wooner $L B$, Bernatz PE. Atypical carcinoid tumours of the lung. Thoracic Cardiovase \$urg 64: $413-421,1972$.

35. Warren VH, Gould VE. Neuroendocrine neoplasms of the lung. A 10 year perspective of their classification. Zentralts Pathol 139: 107-113, 1993.

36. Travis WD, Linnoila RI, Tsokos MG, Hitchoock CL, Cutler GB, Nieman L, Chrousos G, Pass H, Doppman J. Neuroendocrine tumors of the lung with proposed criteria for large cell neuroendocrine carcinoma. An ultrastructural, immunohistochemical, and flow cytometric study of 35 cases. Am J Surg Pathol 15: 529-553, 1991.

37. Paladugu RR, Benfield JR, Pak HY, Ross RK, Teplitz RL. Bronchopulmonary Kulchitzky cell carcinomas. A new classiffcation scheme for typical and atypical carcinoids. Cancer 55: 1303$1311,1985$.

38. De Bruine AP, Bosman FT. Neuroendocrine tumours in the respiratory tract. Acta Histoch suppl XXXVIII: $99-105,1990$.

39. McDowell EM, Harris CC, Trump BF. Hisiogenesis and morphogenesis of bronchial neoplasms. In: Morphogenesis of lung cancer. Y Shisomato, MR Melamed and P Nettesheim (eds), CRC Press, Boca Raton, FL, Vol II, pp 1-37, 1982.

40. McDowell EM, Trump BF. Pulmonary small cell carcinoma showing tripartite differentiation in individual cells. Hum Pathol 12: 286-294, 1980.

41. Mooi WJ, Dingemans KP, Wagenaar SSc, Hart AAM, Wagenvoort CA. Ultrastructural heterogeneity of lung carcinomas: representativity of samples for electron microscopy in tumor dassification. Hum Pathol 21: 1227-1234, 1990.

42. Neal MH, Kosinski $R$, Cohen P, Ohrenstein JM. Atypical endocrine tumors of the lung: A histologic, ultrastructural and clinical study of 19 cases. Hum Pathol 17: 1264-1277, 40.

43. Gazdar AF, Helman LJ, Israel MA, Russell EK, Linnoila RI, Mulshine JL, Schuller HM, Park JG. Expression of neuroendocrine cell markers L-dopa decarboxylase, chromogranin A, and dense core granules in human tumors of endocrine and nonendocrine origin. Cancer Res 48: 4078-4082, 1988.

44. Linnoila RI, Mulshine IL, Steinberg SM, Funa K, Matthews MJ, Cotelingam JD, Gazdar AF. Neuroendocrine differentiation in endocrine and non-endocrine lung carcinomas. Am Clin Pathol 6: 641-652, 1988 .

45. Mooi WJ, Dewar A, Springall DR, Polak JM, Addis BJ. Non-small cell lung carcinomas with neuroendocrine features. A light microscopic, immunohistochemical and ultrastructural study of 11 cases. Histopathol 13: 329-337, 1988.

46. Mooi WJ, Wagenarar SiSc, Schol D, Hilgers J. Monoclonal antibody $123 \mathrm{c} 3$ in lung tumour classification: immumohistology of 358 resected lung tumours. Mal Cell Probes $2: 31-37,1988$.

47. Graxiano SL, Tatum AH, Newmann NB, Oler A, Kohman LJ, Veit LJ, Gamble GP, Coleman

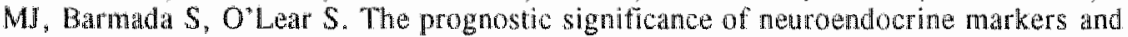
carcinoembryonic antigen in patients with resected stage I and II non-small cell lung cancer. Cancer Res 54: 2908-2913, 1994.

48. Kiriakogiani-Psarapoulou $\mathrm{P}$, Malamou-Mitsi V, Martinopoulou U, Legaki S, Tarnvakis $N$, Vretou $E$, Fountzilas $G$, Skarlos D, Kosmidis P, Pavlidis $\mathbb{N}$. The value of nenroendocrine markers in non-small cell lung cancer: a comparative immunohistopathologic study. Lung Cancer 1. $1: 353-364,1994$.

49. Loy TS, Darkow GVD, Quesenberry JT. Immunostaining in the diagnosis of pulmonary meuroendocrine carcinomas. An immunohistochemical study with ultrastructural correlations. Am J Surg Pathol 19: 173-182, 1995.

50. Broers JLV, Klein Rot M, Oostendorp T, Huysmans A, Wagenaar SSc, Wiersma van Tiburg AIM, Vooijs GP, Ranaekers FCS. Immunosytochemical detection of lung cancer heterogeneity using antibodies to epithelia', neuronal, and neuroendocrine antigens. Cancer Res 47: $3225-3234,1987$

51. Berendsen HH, De Leij L, Poppena S, Postmus PE, Boes A, Sluiter HI. Clinical characterization of non small cell lung cancer tumors showing neuroendocrine differentiation features. J Clin Oncol 7: 1614 1620, 1989.

52. Graziano SL, Mazid R, Newman N, Tatum A, Oler A, Mortimer JA, Gullo JJ, DiFino SM, 
Scalzo AJ. The use of neuroendocrine immunoperoxidase markers to predict chemotherapy response in patients with non-small-cell lung cancer. J Clin Oncol 7: 1398-1406, 1989.

53. Skov BG, Sorensen BJ, Hirsch FR, Larsson LI, Hansen HH. Prognostic impact of histologic demonstration of chromogranin $A$ and neuron-specific enolase in pulmonary adenocarcinonat. Ann Oncol 2: 355-360, 1991.

54. Souhani RL. Neuroendocrine phenotype, chemosensitivity and prognosis in ademocarcinoma of the lung. Ann Oncol 2: 323-324, 1991.

55. Kibbelaar RE, Moolenaar KEC. Michalides RJAM, Van Bodegom PC, Vanderschueren RGJRA. Wagenaar SS, Dingemans KP, Birter-Suermann D, Dalesio $O$, van Zandwijk $N$, Mooi WJ. Neural cell adhesion molecule expression, neuroendocrine differentation and prognosis in lung carcinoma. Eur J' Cancer 27: 431-435, 1991.

56. Carles J, Rosell $\mathbb{R}$, Ariza A, Pellicer I, Sanchez JJ, Fernandez-Vasalo G, Abad A, Barnadas A. Neuroendocrine differentiation as aprognostic factor in non-small cell lung cancer. Lung Cancer 10: $209-219,1993$.

57. Shaw GL, Gazdar AF, Phelps R, Linnoila RI, Thde DC, Johnson BE, Oie HK, Pass HI, Steinberg SM, Ghosh BC, Walsh TE, Nesbitt JC, Cotelingham JD, Minna JD, Mulshine JL. Individuallized chemotherapy for patients with non-small cell lung cancer determined by prospective identification of neuroendocrine markers and in vibro drug sensitivity testing. Cancer Res 53: 5181-5187, 1994.

58. Sundaresan V, Reeve JG, Stenning S, Stewart S, Bleehen NM. Neuroendocrine differentiation and clinical behaviour in non-small cell lung tumours. Br J Cancer 64: 333-338, 1991.

59. Dardick 1, Rippstein P, Perkins $G$. Reliability of criteria for ultrastructural identification of netroendocrine granules. Ultrastruc Pathol 17:37-47, 1993.

60. Grimelius $\mathbb{L}$. The argyrophyl reaction in islet cells of adult human pancreas studied with a new silver nitrate procedure. Acta Soc Med Upsaliensis 73: 271-294, 1968.

61. Solcia E, Capella C, Buffa R, Frigerio B. Histochemical and ultrastructural studies on the argentaffin and argyrophyl cells of the gut. In: Chromaffin, enterochromaffin and related cells. RE Coupland and T Fujita (eds), Elsevier, New York, pp 209-225, 1976.

62. Singh 1. A modification of the Masson-Hamperl method for staining of argentaffin cells. Anat Anz 115: 81-82, 1964 .

63. Erspamer $\mathrm{V}$, Asero B. Identification of enteramine, the specific hormone of the enterochromaffin cell system, as 5-hydroxytryptamine. Nature $\| 69: 800-801,1952$.

64. Jensen SM, Gazdar AF, Cuttitta F, Russell EK, Linnoila RI. A comparison of synaptophysin, chromograrin and $\mathbb{L}$-dopa decarboxylase as markers for neuroendocrine differentiation in lung cancer cell lines. Cancer Res 50: 6068-6074, 1990.

65. Christenson $\mathrm{JG}_{3}$, Dairman $\mathrm{W}$, Udenfriend $\mathrm{S}$. On the identity of DOPA decarboxylase and 5 hydroxytryptophan decarboxylase. Proc Natl Acad Sci USA 69: 343-347, 1972.

66. Gazdar AF, Zweig MH, Carney DN, Van Steirteghen AC, Baylin SB, Minna JD. Levels of creatine kinase and its BB isoenzyme in lung cancer specimens and cultures. Cancer Res 41: 2773-2777, 1981.

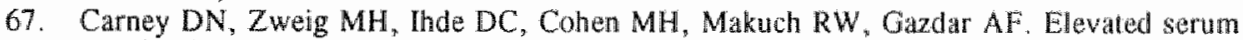
creatine kinase $\mathrm{BB}$ levels in patients with small cell lung cancer. Cancer Res 44: 5399-5403, 1984.

68. Bepler $\mathcal{G}$, Jaques $G$, Koehler $A$, Gropp $C$, Havemann $K$. Markers and characteristics of human SCLC cell لines, J Cancer Res Clin Oncol 113:253-259, 1987.

69. Rubery ED, Doran JF, Thompson RJ. Brain-type creatine kinase BB as a potential tumour marker-serum lewels measured by radioimmunoassays in 1015 patients with histologically confirmed malignancies. Eur $J$ Clin Oncol 18: 951-956, 1981.

70. Jaques $G$, Bepler $G$, Holle $R$, Wolf $M$, Hannich $T$, Gropp $C$, Havemann $K$. Prognostic value of pretreatment carcinoembryonic antigen, neuron-specific enolase, and creatine kinase-BB levels in sera of patients with small-cell Jung cancer. Cancer $62: 125-134,1988$.

71. Schmechel D, Marangos PJ, Brightman M. Neuron specific anolase is a molecular marker for peripheral and central neuroendocrine cells. Nature 276: 834-836, 1978.

72. Sheppard MN, Marangos PJ, Bloom SR, Polak JM. Neuron specific enolase: a marker for the early development of nerves and endocrine cells in the human lung. Life Sci 34: 265-271, 1984.

73. Sheppard MN, Corrin B, Bennett MH, Marangos PJ, Bloom SR, Polak JM. Immunocytochemicall localization of neuron specific enolase in small cell carcinomas and carcinoid tumours of the lung. Histopathology 8: 171-181, 1984.

74. Said JW, Wimadalal S, Nash G, Shintaku P, Heusser RC, Sassoon AF, Lloyd RV. Immunoreactive neuron-specific enolase, bombesin and chromogranin as markers for neuroendocrine 
lung twmors. Hum Pathol 16: 236-240, 1985 .

75. Hamoto $H$, Takahashi $Y$, Koshikawa $T$, Nagura $H$, Kato K. Immunohistochemical localization of gamma enolase in normal human tissues other than nervous and neuroendocrine tissues. Lab Invest $52: 257-262,1985$.

76. Pahman $S$, Esscher $T$, Nilsson $K$. Expression of $\gamma$ subunit of enolase, neuron specific enolase in human non-endocrine tumorg and deriwed cell lines. Lab Invest 54: 554-560, 1986.

77. Addis BJ, Hamid Q, Ibrahim NBN, Fahey M, Bloom SR, Polak IM. Immunohistochenical markers of small cell carcinoma and related neuroendocrine tumours of the lung. $\mathrm{I}$ Pathol 153 : $137-150,1987$.

78. Carney DN, Marangos PJ, Thde DC, Bunn PA, Cohen MH, Minna JD. Serum neurom-specific enolase: marker for disease extent and response to therapy of small-cell lung cancer. Lancet 1: $583-585,1982$.

79. Splinter TAW, Cooper EH, Kho GS, Osterom $\mathbb{R}$, Peake MD. Neuron-specific enolase as a guide to the treatment of small cell lung cancer. Eur J Cancer Clin Oncol 23: 171-176, 1987.

80. Esscher T, Steinholte L, Bergh J, Nou E, Nilsson K, Pahlman S. Neurone-specific enolase: a ugeful diagnostic serum marker for small cell carcinoma of the lung. Thorax 40: 85-90, 1985 .

81. Johnson DH, Greco FA. Biomarkers of small cell lung cancer. In: Lung Cancer Differentiation. Implications for diagnosis and treatment. SD Bernal and PJ Hesketh (eds), Marcel Dekker Inc., New York, pp 217-252, 1992.

82. Rougon $\mathrm{G}$, Deagostini-Bazin H, Hirn M, Goridis C. Tissue- and developmental stage specific forms of a neural cell surface antigen linked to differences in glycosylation of a common polypeptide. EMBO J 1: $1239-1244,1982$.

83. Cunningham BA, Hemperly JJ, Murray BA, Prediger EA, Brackenbury $R$, Edelman GM. Neural cell adbesion molecule: structure, immunoglobulin-like domains, cell surface modulation, and altermative RNA splicing. Science (Wash DC) 236: 799-806, 1987.

84. Rutishauer U, Acheson A, Hall AK, Mann DM, Sunshine J. The neural cell adhesion molecule (NCAM) as a regulator of cell-cell inteactions. Science (Wash DC) 240:53-57, 1988.

85. Stahel RA, Gilks WR, Lehmann H-P, Schenker T. Third International Workshop on Lung Tumor and Differentiation Antigens: overview of the results of the central data analysis. Int $J$ Cancer suppl 8: 6-26, 1994.

86. Beverly PCL, Souhami RL, Bobrow L. Results of central data analysis. Lung Cancer $4: 15-36$, 1988.

87. Bewerly PCL, Olabrian Y, Ledermann JA, Bobrow LG, Souhami RL. Results of central data analysis. Br J Cancer 63, suppl XIV: 10-19, 1991.

88. KKibbelaar RE, Moolenaar CEC, Michalides RJAM, Bitter-Suermann D, Addlis BJ, Mooi WJ. Expression of the embryonal neural cell adhesion molecule N-CAM in lung carcinoma. Diagnostic usefuness of monoclonal antibody 735 for the distimction between small cell lung cancer and non-small cell lung cancer. \& Pathol 159: 23-28, 1989.

89. Broers JLV, Mijnheere EP. Klein Rot $M$, Schairt $G$, Sijlmans A, Boerman OC, Ramaekers FCS. Novel antigens characteristic of neuroendocrine malignancies. Cancer $67: 619-633,1991$.

90. Schol DJ, Mooi WJ, van der Gugten AA, Wagenaar SSc, Hilgers I. Monoclonal antibody $123 \mathrm{c3}$, dentifying small cell lung carcinoma phemotype in lung tumours, recognizes mainly, but not exclusively, endocrine and neuron-supporting normal tissues. Int $J$ Cancer suppl $2: 34-40$,
1988 .

91. Bum P, Linnoila 1, Minna J, Carney D, Gazdar A. Small cell lung cancer, endocrine cells of the fatal bronchus, and other neuroendocrine cells express the Leu-7 antigenic detarminant present on matural killer cells. Blood 65: 764-768, 1985.

92. MeGarry R, Helfand $S$, Quarles $R$, Roder J. Recognition of myelin-associated glycoprotein by the monodonal antibody HNK-1. Nature (Lond) $306: 376-378,1983$.

93. Tischler AS, Mobtaker H. Marn K, Numemacher G, Jason WJ, Dayal Y, Delellis RA, Adelmarn L, Wolfe HJ. Anti-lymphocyte antibody Leu-7 (HNK-1) recognized a constituent of neutoendocrine granule matrix. J Histochem Cytochem 34: 1213-1216, 1986.

94. Tsutsumi $Y$. Leum immunoreactivity as histochemical marker of paraffin-embedded neuroendocrine tumours of the lung. Acta Histochem Cytochem 17: 15-22, 1984.

95. Doria MI, Montag AG, Franklin WA. Immunophenotype of small cell carcinoma. Expression of

96. Wiedentmann B, Huttner WB. Synaptophysin and cheloid antigens. Cancer 62: 1939-1945, 1988, constituents of distinct types of neuroendocrine vesiclogranins/secretogranins - widespread Virchows Archiv B Cell Pathol 58: 95-121, 1989.

97. Rosa $P$, Fumagalli $G, Z$ Zanini $A$. Huttmer $W B$. The major tyrosine-sulfated protein of the bovine 
anterior pituitary is a secretory proten present in gonadotrophs, thyrotrops, mammotrophs and corticotrophs. ICell Biol 100: $928-937,1985$.

98. Eiden LE. Is chromogranin a prohormone? Nature 325: $301,1987$.

99. lacangelo AL, Fischer-Colbrie $\mathbb{R}$, Koller KJ, Brownstein MJ, Lee EE. The sequence of porcine chromogranin A messenger RNA demonstrates that chromogranin A can serve as the precursor for the biologically active hormone, pancreastatin. Endocrinol $122: 2339-2341,1988$.

100 Tötsch M, Müller LC, Hittmair A, Offner D, Gibbs A, Schmid KW. Immunohistodnemical demonstration of chromogranins $A$ and $B$ in neuroendocrine tumors of the lung. Hum Pathol 23: 312-316, 1992 .

101 Leube RE. Expression of the synaptophysin gene family is not testicted to neuronal and neuroendocrine differentiation in rat and human. Differentiation 56:163-171, 1994.

102. Lee 1. Gould VE, Moll R, Wiedenmann B, Franke WW. Synaptophysin expressed in the bronchopulmonary tract: neuroendocrine cells, neuroepithelial bodies and neuroendocrine neoplasms. Differentiation 34: 115-125, 1987.

103. Gould VE, Lee 1, Warren WH. Immunohistochemical evaluation of neuroendocrine cells and neoplasms of the lung. Path Res Pract 183: 200-213, 1988.

104. Franke WW, Schmid E, Osborn M, Weber K. Different intermediate-sized filaments distinguished by immunofluorescence microscopy. Proc Natl Acad Sci USA 75: 5034-5038, 1978.

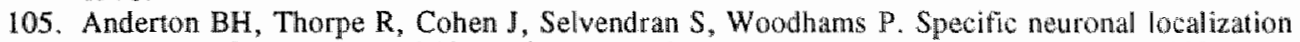
by immunofluorescence of $10 \mathrm{~nm}$ filament polypeptides. J Neurocytol $9: 835-844,1980$.

106. Lehto VP, Miettinen M, Dahl D, Virtanen I. Bronchial carcinoid cells contain neural-type intermediate fillaments. Cancer 54: 624-628, 1984.

107. Lehto VP, Stenman S, Miettinen M, Dahl D, Virtanen I. Expression of a neural type of intermediate fillaments as a distinguishing feature between oat-cell carcinoma and other lung cancers. Am J Pathol 110:113-118, 1983.

108. Bergh J, Nilsson K, Dahl D, Anderson L, Virtanen 1, Lehto VP. Expression of intermediate filaments in established human Jung cancer cell lines - an indicator for differentiation and derivation. Lab Invest 51: 307-316, 1984.

109. Broers JLV, Carney DN, Klein Rot M, Schaart G, Lane EB, Vooijs GP, Ramaekers FCS. Intermediate filament proteins in classic and variant types of small lwcell lung carcinoma cell lines." a biochemical and immunochemical analysis using a panel of monoclonal and polyclonal antibodies. J Cell Sci 3: 37-60, 1986.

110. Van Muijen GNP, Ruiter DJ, van Leeuwen C, Prins FA, Rietsema K, Warnaar SO. Cytokeratin and neurofilament in lung carcinomas. Am J Pathol 116:363-369, 1984.

111. Wagenaar SSc, Tazelaar HD. Ten years after the WHO classiffication for lung cancers: where are we? Lung Cancer 11 suppl 3: 39-43, 1994.

112. Roebroek AJM, van de Velde HJK, wan Bokhoven A, Broers JLV, Ramaekers FCS, Van de Ven WJM. Cloning and expression of altermative transcripts of a novel neuroendocrine-specific gene and identification of its 135-kDa translational product. II Biol Chem 268: 13439-13447, 1993. 



\title{
CHAPTER 1
}

\section{CLUSTER-10 LUNG CANCER ANTIBODIES RECOGNIZE NSPS, NOVEL NEUROENDOCRINE PROTEINS ASSOCIATED WITH MEMBRANES OF THE ENDOPLASMIC RETICULUM}

Nicolle HM Senden, Helgi JK van de Velde, Jos LV Broers, Erika Dr Timmer, Anton JM Roebroek, Wim JM Van de Ven, Frans CS Ramaekers

Int $J$ Cancer supplement 8: 84-88, 1994

\begin{abstract}
We have identified a novel gene (the NSP-gene) encoding three transcripts and coding for three neuroendocrine-specific proteins (NSPs), by screening a cDNA expression library of the small cell lung cancer (SCLC) cell line NCI-H82 with the cluster-10 lung cancer antibodies RNL-2 and RNL-3. The three transcripts code for NSPs with apparent molecular weights (Mw) of $135 \mathrm{kDa}$ (NSP-A), $43-45$ and $35 \mathrm{kDa}$ (NSP-B) and $23 \mathrm{kDa}$ (NSP-C). NSP-A and NSP-B are recognized by antibodies RNL-2 and RNL-3, while second generation antibodies, specifically recognizing NSP-A and NSP$C$, have been produced after immunization with a hybrid protein obtained after bacterial expression of the largest NSP transcript or with a synthetic peptide specific for NSP-C. The NSPs exhibit a highly restricted distribution pattern and are found mainly in neural and neuroendocrine (NE) cell types, and in NE tumors. Of the different types of lung tumors, mainly SCLCs and carcinoids were positive in immunocytochemical assays using the anti-NSP antibodies, while non-SCLCs were in general negative. The subcellular distribution of the NSPS was studied in human SCLC cell lines. They do not colocalize with components typical of NE granules, such as synaptophysin and chromogranin. The use of NSP antibodies in the immunofluorescence technique applied to cultured SCLC cells, made it obvious that these proteins localize in the endoplasmic reticulum (ER). Cell fractionation procedures, monitored by immunoblotting assays, indicated an association of the NSPs with the microsomal fraction, from which they could be solubilized with Triton X-100. Gel filtration studies with this solubilized fraction revealed that NSPs form supramolecular aggregates with a Mw of more then $500 \mathrm{kDa}$.
\end{abstract}


In our study of the biological behaviour of small cell lung cancer (SCLC), and in particular of its most agressive form, the variant type of SCLC [1,2] we have searched for differences in the molecular composition between the classic and variant type of SCLC. The approach that was initially chosen included the preparation of variant type SCLC specific monoclonal antibodies (mabs). In this way two antibodies, designated RNL-2 and RNL-3, were obtained and tested for reactivity using a large panel of lung cancer cell lines, as well as normal and malignant human tissues. Special emphasis was placed on tissues and tumors with NE features. From these studies it became obvious that the mabs RNL-2 and RNL-3, which have been grouped as cluster-10 antibodies during the Third International Workshop on Lung Tumours and Differentiation Antigens, organized by the International Association for the Study of Lung Cancer (Zürich, September 1993), recognized NE-related cellular constituents, which could be identified in immunoblotting as a group of 3 to 4 proteins with $\mathrm{Mw}$ varying from 35 to $135 \mathrm{kDa}$. After detailed molecular analysis, these proteins were found to be derived from one gene, which we designated the neuroendocrine-specific protein (NSP)-gene. Here, we present a review of our studies on the products of this NSP-gene $[3,4,5]$.

\section{The NSP-gene, its transcripts and neuroendocrine-specific expression pattern}

Screening of a prokaryotic cDNA expression library of the variant SCLC cell line NCI-H82, using a mixture of mabs. RNL-2 and RNL-3, revealed five cDNAs. Using the largest CDNA as molecular probe in Northern blot analysis of SCLC cells and carcinoid tissue, we identified three transcripts of different length. These three transcripts with an estimated size of $3.4,2.3$, and $1.8 \mathrm{~kb}$ (Fig. 1) showed identical 3'-end sequences, but unique 5'-end sequences. Comparison of the cDNA sequences of these transcripts revealed that the unique 5 '-end sequences of the $2.3 \mathrm{~kb}$ transcript comprised 41 nucleotides and those of the $1.8 \mathrm{~kb}$ transcript at least 88 nucleotides (Fig. 1).

Southern blot analysis, sequencing and YAC cloning experiments indicated that the various transcripts originate from a single gene. The NSP-gene has recently been mapped by fluorescence in situ hybridisation analysis to human chromosome 14q21q22 [6].

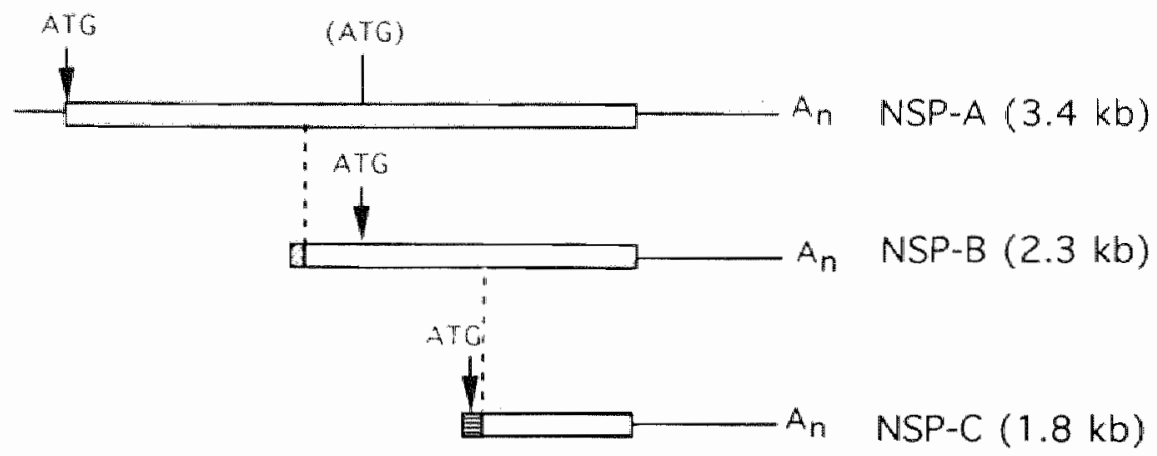

Fingure 1. Schematic representation of the NSP transcripts of $3.4 \mathrm{~kb}, 2.3 \mathrm{~kb}$ and $1.8 \mathrm{~kb}$. The open lieading frames in the three cDNAs are represented as boxes. Unique 5 '-end sequences in the $2.3 \mathrm{~kb}$ and $1.8 \mathrm{~kb}$ transcripts are represented as at shaded box. Regions that are identical in the three transcripts are linked via broken lines. The relative positions of the predicted translation initiation are
indicated. 
Northern blot analysis of mRNA from NCI-H82 cells revealed very high levels of the $2.3 \mathrm{~kb}$ transcript and low levels of the $3.4 \mathrm{~kb}$ transcript. Two out of four other SCLC cell lines and a primary carcinoid lung tumor showed the presence of either one or both of the 3.4 and $1.8 \mathrm{~kb}$ transcripts. Expression of the 3.4 and $1.8 \mathrm{~kb}$ transcript was also found in two human neuroblastoma cell lines, in two mouse pituitary adenoma cell lines, in a rat medullary thyroid carcinoma cell line and a rat pheochromocytoma cell line. In human parathyroid and thyroid, weak expression of only the $3.4 \mathrm{~kb}$ transcript could be detected. No NSP-mRNA has been observed in three non-NE human cell lines, i.e. a larynx carcinoma cell line, an orall carcinoma cell line and a pharynx carcinoma cell line. In mouse brain, testis and ovary expression of two NSP transcripts were found, corresponding to human 3.4 and $1.8 \mathrm{~kb}$ mRNA. Mouse liver, spleen, heart, kidney and lung were negative. In rat pituitary transcripts of $3.4 \mathrm{~kb}$ and $1.8 \mathrm{~kb}$ were detected.

\section{NSPs and anti-NSP antibodies}

Nucleotide sequence analysis of the three different NSP transcripts revealed open reading frames for proteins of 776 (calculated Mw of $84 \mathrm{kDa}$ ), 356 (calculated Mw of $39 \mathrm{kDa}$ ) and 208 (calculated $\mathrm{Mw}$ of $25 \mathrm{kDa}$ ) amino acids, respectively. Although the calculated $\mathrm{Mw}$ of the protein deduced from the $3.4 \mathrm{~kb}$ sequence $(84 \mathrm{kDa})$ differed significantly from the $\mathrm{Mw}$ based on the observed electrophoretic mobility (135 kDa), transfection of the complete coding sequences of the $3.4 \mathrm{~kb}$ transcript into COS- 1 cells, followed by immunoprecipitation of the produced protein, revealed the production of a $135 \mathrm{kDa}$ protein. Similarly, immunoprecipitation of proteins from COS- 1 cells transfected with the middle transcript, using RNL-2, resulted in protein bands ranging from 45 to $35 \mathrm{kDa}$. An explanation for the apparent discrepancy in calculated and estimated Mw of in particular NSP-A can be found in the fact that the NSPs each contain an amino-terminal region with a relatively high number of negatively charged residues. These properties may lead to a lower mobility in SDS gels and do also explain the low isoelectric pH of NSPs, i.e. a calculated pI of 4.93 for NSP-B and a calculated pI of 4.35 for NSP-A. Also, NSP-A and NSP-B appeared to be highly phosphorylated, preferentially on serine residues. NSP-A was shown not to be glycosylated. The smallest transcript codes for a $23 \mathrm{kDa}$ protein, designated NSP-C. NSP-C was found not to be phosphorylated.

A typical feature found in all three NSPS is that the common C-terminal domain contains two large hydrophobic regions, probably representing membrane spanning domains. Although the NSPs do not exhibit any apparent amino acid sequence homology to known proteins, they share some structural features with other NE

proteins, for instance the synaptic vesicle associated protein amphiphysin [7] and chromogranin A and B [8]. NSP-A and NSP-B are recognized by antibodies RNL-2 and RNL-3 as concluded from the fact that both antibodies revealed four 35 to $45 \mathrm{kDa}$ proteins (including a 43 to 45 triplet) and the $135 \mathrm{kDa}$ protein in Western blot analysis of the SCLC cell line NCI-H82 (Fig. 2). Competition binding assays showed that the two antibodies recognize different epitopes of these proteins. In another SCLC cell line, i.e. SCLC-2 $1 \mathrm{H}$ only the $135 \mathrm{kDa}$ protein, but not the 43 to 45,35 or $23 \mathrm{kDa}$ NSPs, could be detected. RNL-2 and RNL-3 showed neither reactivity with the NSP-C protein nor with the COS-1 cells transfected with the NSP-C transcript, indicating that these two reagents do not recognize NSP-C epitopes. Second generation mouse mabs 


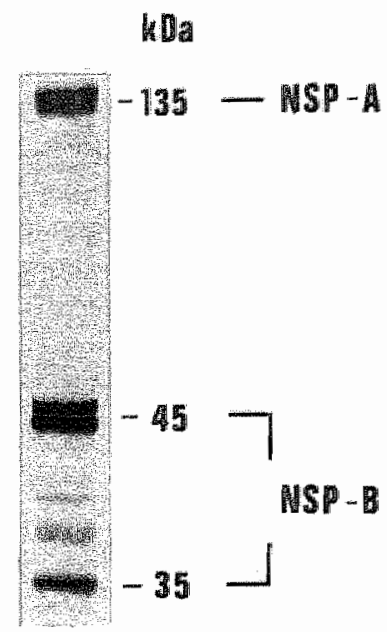

Figure 2. NSP-A (135 KDa) and NSP-B (43-45 kDa triplet, $35 \mathrm{kDa})$ as recognized in an NCI-H82 cell Iysate using immunoblotting with RNL-2 and a mixture of MON 160 , MON-161 and MON-162.
MON-160, MON-161 and MON-162 were produced after immunization with a partially purified, bacterially expressed NSP-A hybrid protein. Because of their exclusive reactivity with the $135 \mathrm{kDa}$ protein in immunoblots of $\mathrm{NCI}-\mathrm{H} 82$ and reactivity with different fusion proteins, these second generation antibodies apparently recognize different epitopes located at the unique amino-terminal part of NSP-A. These antibodies did also detect the $135 \mathrm{kDa}$ protein in other SCLC cell lines and showed tissue distribution patterns similar as those observed for RNL-2 and RNL-3. Using the NSP-A hybrid protein we produced a polyclonal rabbit antiserum POL-1, that was shown to react with NSP-A and NSP-B in NCIH82. A rabbit NSP-C antiserum POL-8 was raised against a synthetic peptide consisting of the twenty amino-terminal residues of deduced NSP-C. This antiserum reacted strongly with the NSP-C fusion protein in immunoblotting, in COS-1 cells expressing the $1,8 \mathrm{~kb}$ NSP-C transcript, in SCLC$21 \mathrm{H}$ celis and in rat brain. On basis of the results described above the epitopes for the different antibodies can be mapped to regions of the different NSPs as shown in Fig. 3

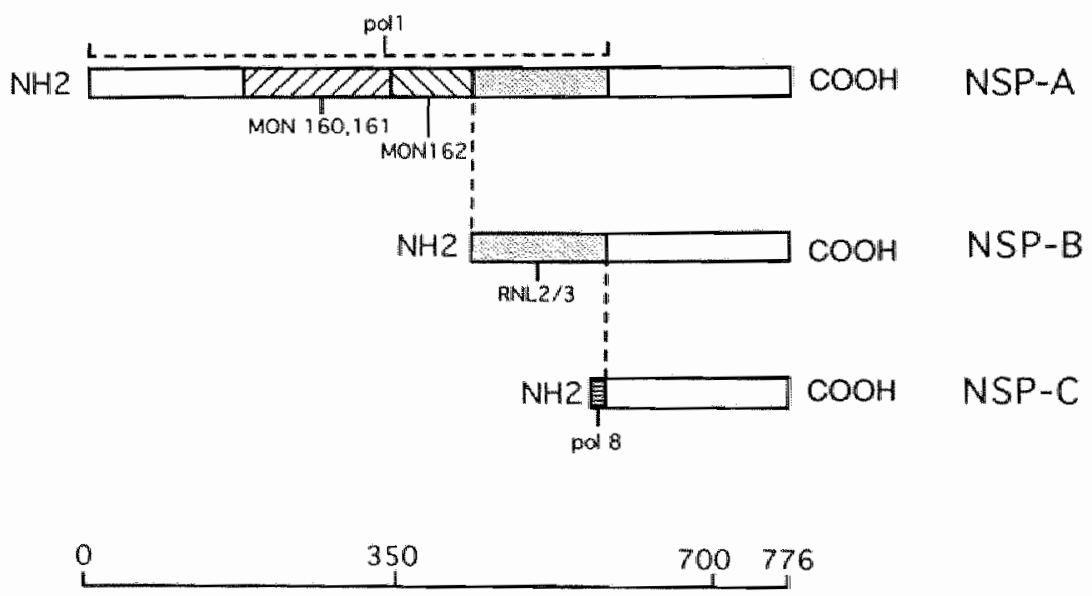

Figure 3. Schematic representation of the deduced domain structure of the three NSP-gene encodad proteins, NSP-A, NSP-B and NSP-C and mapping of the epitopes recognized by the different NSP antibodies used in this study. Regions that are identical in the three proteins are linked via broken lines. The unique amino-terminal region ( 20 amino acid residues long) of NSP-C is represented by a
shaded box. 


\section{Localization and supramolecular organization of NSPS}

To define their subcellular localization in lung cancer cells, we studied the distribution of NSPs in different soluble and membranous fractions of SCLC cell lines NCI-H82, NCI-H524 and SCLC-21H. A minor amount of NSPS was found in the PBS soluble fraction of these cells, but the main NSP fraction was found in the $4400 \mathrm{~g}$ pellet and in the $100,000 \mathrm{~g}$ microsomal fraction. These results indicated that the NSPs are associated with membranous components. They could be solubilized from these membranous fractions with Triton $X-100$. These experiments revealed also a codistribution of the individual NSPs in these subcellular compartments. Gel filtration experiments, using the PBS soluble or Triton X-100 soluble fraction of SCLC cell homogenates, showed that the NSPs are aggregated into large proteinaceous complexes with a Mw of more then $500 \mathrm{kDa}$. Immunofluorescence studies of cell cultures were performed to elucidate the subcellular localization of these NSP aggregates. In adherent cells of SCLC cell lines NCI-H82 and NCI-H524, strong perinuclear staining and a uniform staining of a fibro-granular network, spanning the whole cytoplasm, was observed (Fig. 4A). A similar staining pattern of a lace-like network, seen most clearly in the cellular periphery, could be demonstrated in COS-1 cells transfected with NSP-A, NSP-B and NSP. C cDNA constructs using antibodies RNL-2, RNL-3 (Fig. 4B), a mixture of MON160 , MON-161 and MON-162 or POL-8. This typical staining pattern suggested that the NSPs might be associated with either cytoskeletal or membranous structures in the cell. Colocalization studies with antibodies to microfilaments, microtubules, intermediate filaments such as cytokeratins, vimentin, neurofilaments, showed a partial overlap in the staining pattern of microtubules and NSPS.
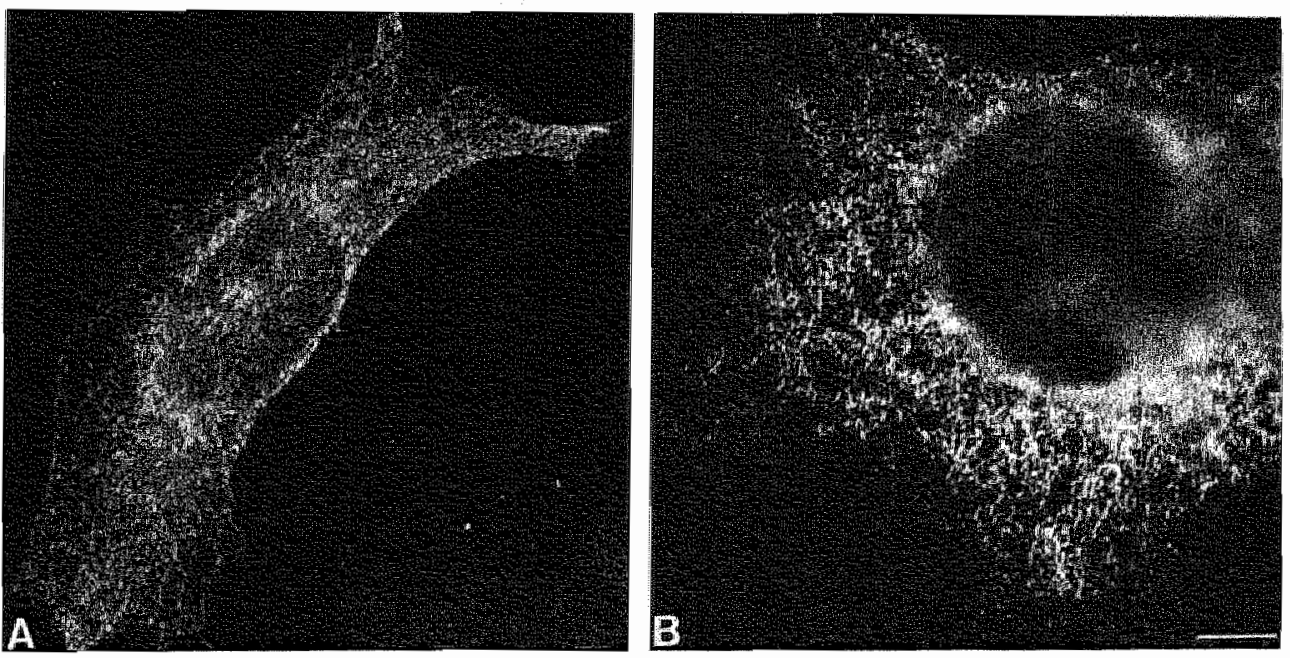

Figure 4. Immunofluorescence microscopy with antibody RNL-3 reweals that NSPs are localized in the endoplasmic reticulum (ER) of NCT-H524 cells (A) and migrate to the ER of COS 1 cells after transfection with the NSP-B construct (B; RNL-2). Bar (A) $8.5 \mu \mathrm{m}$; (B) $10.5 \mu \mathrm{m}$. 
The results of double immunofluorescence studies with antibodies to proteins known to occur in the ER (such as $\mathrm{Ca}^{2+}$-ATPase) clearly showed that NSPs are localized on this membranous structure, in accordance with the observation that the NSPS are associated with the microsomal cell fraction. From analysis of deletion mutants it appeared that the hydrophobic carboxy-terminal portion of the NSPs is critical for the observed membrane binding. Double-label immunofluorescence studies with antibodies to synaptophysin excluded an association of NSPs with small NE vesicles. Staining with chromogranin antibodies revealed that the cells tested do not contain dense core secretory granules. We conclude that the NSPs form, membrane-anchored aggregates in the ER of NE cells.

\section{Tissue distribution of NSPS}

In normal tissues, reactivity with RNL-2 and RNL-3 antibodies was observed in brain Purkinje cells (Fig. 5A), pancreatic islet cells (Fig. 5B), cells in the pituitary gland and some (peripheral) nerve fibers. Spleen reticular fibres seem to be stained, while the prostatic epithelium and some suprabasal cells of the tongue epithelium were also positive with RNL-2 and RNL-3. In lung, only positive staining was observed in the (sero)-mucous glands. No reactivity was seen in the gastrointestinal tract, nor in thyroid and adrenal gland. Analysis of lung carcinomas showed a positive reaction in part of the NE tumor types i.e., in 5 out of 14 SCLC cases (Fig. 5C) and in 6 out of 8 carcinoid cases (Fig. 5D). In general, no positive reaction was seen in squamous cell carcinomas, adenocarcinomas or large cell carcinomas of the lung. However, in a few cases of poorly differentiated squamous carcinomas and in one case of a large cell carcinoma, focal positivity was seen. In non-pulmonary human tumors a staining reaction was observed in a subset of NE tumors, such as pituitary adenomas (Fig. 5E) and insulinomas (Fig. SF). Some other malignancies, such as medullary Schwannoma, prostate carcinomas, thyroid carcinomas and melanomas, were positive. From these data, we conclude that the antibodies recognize a subset of NE tissues and tumors.

Altogether, the NE specific expression pattern found in the Northern- and Western blot studies are in accordance with the results of the immunohistochemical studies.

Species cross-reactivity of the antibodies RNL-2 and RNL-3 was restricted to rabbit brain and rhesus monkey. They were negative in rat, chicken and hamster tissues. Second generation antibodies MON-160, MON-161 and MON-162 showed a broader species cross-reactivity, and appeared to cross-react with hamster, mouse and rat cell lines.

\section{DISCUSSION}

We have identified a novel neuroendocrine-specific protein-gene (NSP-gene) encoding a family of proteins with NSP-A $(135 \mathrm{kDa})$, NSP-B $(35,43-45 \mathrm{kDa})$ and NSP-C (23 $\mathrm{kDa}$ ) as its main, known members. The NSP- gene products showed prevalent expression in NE and neural tissues and tumors. The various antibodies to the NSPs, in particular, may therefore become useful for the immunocytochemical recognition of NE cancers. Within the group of SCLC, however, only some of the tumors were found to react with the different NSP antibodies. Our initial aim was directed towards the production of mabs specific for the variant type of SCLC. 

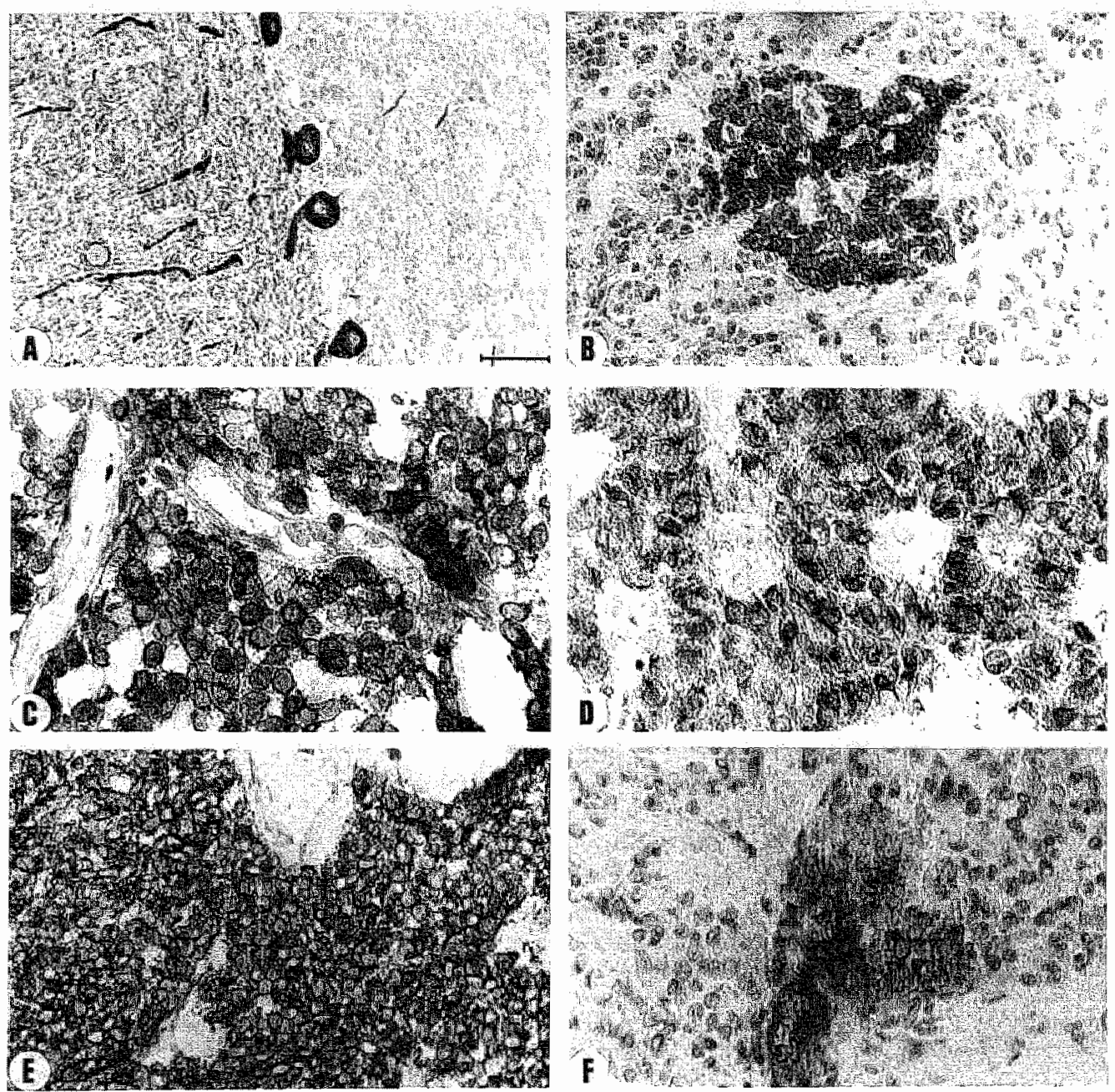

Figure 5. Immunoperoxidase staining patterns of human neural and neuroendocrine tissues and tumors, after incubation with antibodies RNL-2 or RNL-3. (A) Brain Purkinje cells; (B) pancreatic islet cells; (C) small cell lung cancer; (D) lung carcinoid; (E) pituitary adenoma; (F) insulinoma. Bar (A) $40 \mu \mathrm{m}$; B) $53.5 \mu \mathrm{m}$; (C,D) $22 \mu \mathrm{m}$; (E) $20 \mu \mathrm{m}$; (F) $23.5 \mu \mathrm{m}$.

Although our selection procedures were designed to obtain such antibodies, we must conclude that in fact none of the first or second generation antibodies makes a clear cut separation between the classic- and variant-type of SCLC in cell cultures. It remains to be established whether the positively reacting subset of SCLC behaves differently, either clinically or biologically, from NSP-negative SCLC. Also, NSP antibodies can detect the presence of small populations of NE cells in non-NE tumors. In the group of non-SCLC about 10 to $20 \%$ of the tumors exhibit NE characteristics, which appears to 
correlate with poor prognosis [9]. In addition to their application in immunocytochemical assays, the NSP antibodies may well prove useful in serum assays of patients with NE neoplasia. Our preliminary results with RNL-2 and RNL-3, when tested on sera from such patients using a sandwich assay, were negative (data not shown). However, the fact that these two antibodies react most strongly with NSP-B, which has not been found in human solid NE tumors and to a lesser extent with NSP-A, might explain these negative results. Future studies will focus on the usefulness of the second

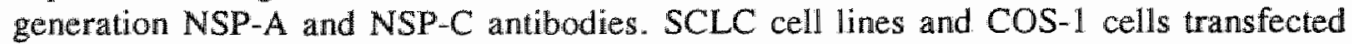
with the different CDNA constructs were used to elucidate the localization and supramolecular organization of the newly identified NE proteins. Immunofluorescence and differential centrifugation studies revealed that NSP aggregates, are associated with the ER. Cell fractionation revealed a strong association of the NSPs with the microsomal fraction, to which they are bound by the hydrophobic carboxy-terminal portion of the NSPs. Despite their NE appearance, NSPs have not been found to be associated with NE vesicles. However, NSPs show some structural similarities with chromogranin $A$ and $B$, such as abundant acidic amino acid regions [8]. The NSPS exhibit even more structural resemblance with the synaptic vesicle associated protein amphiphysin [7]. Like amphiphysin, the NSPs are very acidic, rich in proline residues, contain potential sites for phosphorylation, lack a signal peptide and possess a hydrophobic stretch in the carboxy-terminal part. Our findings indicate that the NSPs are novel, membrane-anchored components of the ER, particularly expressed in cell types with NE differentiation. Whether the NSP aggregates, observed after gel filtration studies, are heterogeneous or homogeneous in composition remains to be established.

\section{Acknowledgements}

We would like to thank Dr G Bepler (Duke University Medical Center, Dept of Medicine, Durham, NC, USA), Dr D Carney (Mater Misericordiae Hospital, Dept of Medical Oncology, Dublin, Ireland) and $\mathrm{Dr} \mathrm{L}$ de Ley (Department of Clinical Immunology, University of Groningen, The Netherlands) for providing cell lines; Dr A Beckers and Dr A Stevenaert (Department of Endocrinology, Sart Tilman, University of Liege, Belgjum) for providing pituitary adenomas; Dr $\mathrm{K}$ Campbell (Howard Hughes Medical Institute, Iowa City, Iowa, USA) for the antiserum against SERCA2b, Dr M Borgers (Janssen Pharmaceutica, Beerse, Belgium) for the antiserum to tubulin and Dr J Askau (DAKO A/S, Glostrup, Denmark) for the antiserum against synaptophysin. This work was supported by the Netherlands Cancer Foundation, grant no. IKL 90-09 and in part by the "Nationaal Fonds voor Wetenschappelijk Onderzoek (NFWO) and the "Geconcerteerde Onderzoekacties 1992-1996". Helgi JK van de Velde is a Research Assistant of the Belgian National Fund for Scientific Research

\section{REFERENCES}

1. Carney DN, Gazdar AF, Bepler G, Guccion JG, Marangos PJ, Moody TW, Zweig MH, Minna ID. Establishment and identification of small cell lung cancer cell lines having classic and variant features. Cancer Res 45; 2913-2923, 1985.

2. Gazdar AF. Advances in the biology of lung cancer. Clinical significance of neuroendocrine differentiation. Chest suppl 96: 39-41, 1989.

3. Broers JLV, Mijnheere EP, Klein Rot M, Schaart G, Sijlmans A, Boerman OC, Ramaekers FCS Novel antigens characteristic of neuroendocrine malignancies. Cancer 67: 619-633, 1991 .

4. Roebroek AJM, van de Velde HJK, van Bokhoven A, Broers JLV, Ramaekers FCS, Van de Ven WJM. Cloning and expression of alternative transcripts of a novel neuroendocrine-specific gene 
and identification of its 135-kDa translational product. J Biol Chem 268: 13439-13447, 1993.

5. Van de Velde HJK, Roebroek AJM, Senden NHM, Ramaekers FCS, Van de Ven WJM. NSPencoded reticulons, neuroendocrine proteins of a novel gene family associated with membranes of the endoplasmic reticulum. I Cell Sci 107: 2403-2416, 1994.

6. Kools PFJ, Roebroek AJM, van de Velde HJK, Marynen $\mathbb{P}$, Bullerdiek $\mathfrak{J}_{\text {, Van }}$ de Ven WJM. Regional mapping of the thuman NSP gene to chromosome region $14 \mathrm{q} 21-q 22$ by fluorescence in situ hybridization analysis. Cytogenet Cell Genet $66: 48-50,1994$.

7. Lichte B, Veh RW, Meyer HE, Kilimann MW. Amphiphysin, a novel protein associated with

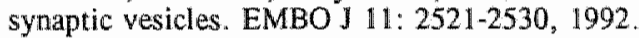

8. Wiedenmann B, Huttner WB. Synaptophysin and chromogranins/secretogranins - widespread constituents of distinct types of neuroendocrine wesicles and new tools in tumor diagnosis.

Virchows Arch Cell Path 58: 95-121, 1989.

9. Linnoila RI, Mulshine JL, Steinberg SM, Funa K, Matthews MJ, Cotelingam JD, Gazdar AF". Neuroendocrine differentiation in endocrine and nonendocrine lung carcinomas. Am $\mathrm{J}$ Clin Path 90: $641-652,1988$. 


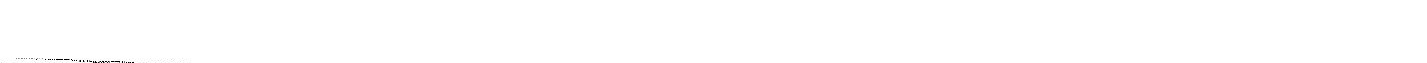




\title{
CHAPTER 2
}

\section{NSP-ENCODED RETICULONS, NEUROENDOCRINE PROTEINS OF A NOVEL GENE FAMILY ASSOCIATED WITH MEMBRANES OF THE ENDOPLASMIC RETICULUM}

\author{
Helgi JK van de Velde, Anton JM Roebroek, Nicole HM Senden, \\ Frans CS Ramaekers, Wim JM Van de Ven \\ $J$ Cell Science 107: 2403-2416, 1994
}

\begin{abstract}
The novel NSP-gene was previously shown to encode, among a variety of neuroendocrine (NE) cell types, two $3^{\prime}$ - overlapping transcripts, a $3.4 \mathrm{~kb}$ one for NSP-A (776 amino acids) and a $1.8 \mathrm{~kb}$ one for NSP-C (208 amino acids). The deduced proteins, which were predicted to possess distinct amino-terminal regions, appeared to exhibit some architectural resemblance to known NE proteins. In this study the biochemical characterization and subcellular localization of the two proteins is addressed. In vitro translation of NSP-A and NSP-C RNA produced proteins of about 135 and $23 \mathrm{kDa}$, respectively. Proteins of similar molecular weights were also detected in immunoprecipitation and Western blot analyses of neural and endocrine cells using specific antiNSP-A or -C antisera; some heterogeneity of NSP-A was observed. NSP-A, but not NSP-C, appeared to be highly phosphorylated and preferentially on serine residues. In immunocytochemical studies, we demonstrated that NSP-A and $-\mathrm{C}$ are associated with the endoplasmic reticulum (ER); NSP-A was found to colocalize with SERCA2b, a membrane-associated $\mathrm{Ca}^{2+}$-ATPase of the ER. In Purkinje cells, we found NSP-A immunostaining in the perikaryon, the extensive dendritic tree and the axon, suggesting association also with the smooth ER. Biochemical studies of NSP-A provided evidence that NSP-A is strongly associated with microsomal membranes and analysis of deletion mutants of NSP-A revealed that the hydrophobic carboxy-terminal portion of the protein, which is also present in NSP-C, is critical for membrane binding. Through database searches, finally, we found two different NSP-related sequences, one in a sequenced region of human chromosome 19, and the second in a human, pancreatic islet-derived partial cDNA, suggesting that the NSP-gene is the prototype of a larger gene family. The results of our studies seem to indicate that the NSPS are novel, membrane-anchored components of the ER for which we propose the name NSPreticulons.
\end{abstract}




\section{INTRODUCTION}

Recent endeavors to dissect molecularly the secretory pathway in eukaryote cells have revealed the structural and functional complexity of this dynamic supramolecular system and provided insight into the diversity of molecular components (for a recent review, see reference 1). A rather central structure of the secretory pathway is the elaborate endomembrane system of the cell, with the multifunctional ER as a major constituent. In general, newly synthesized secretory proteins and a variety of resident proteins of the pathway enter it at the rough ER (RER) after being targeted to and translocated across the RER membrane [2]. Subsequently, the proteins may be sorted selectively to different membrane-delimited organelles including the Golgi apparatus, endosomes, lysosomes, and secretory vesicles. Such transport is thought to be governed, at least in part, by sequential formation and fusion of shuttle vesicles [3]. Sorting is assumed to depend on different signals and mechanisms, and also to include recycling of proteins and membrane structures [4]. Some proteins travel onwards through the pathway all the way to the plasma membrane at the cell surface, where they are finally secreted in a constitutive or regulated fashion. During their flow through the secretory pathway, proteins may be subjected to various processes of posttranslational modification, e.g. endoproteolytic processing of proproteins [5], some of which have already begun in the ER (e.g. removal of signal peptide). Dissection of the supramolecular structures of this pathway into the individual components from which they are built will contribute to the unravelling of the intricate processes involved.

In this context, we have focussed our studies on genes that display neuroendocrinespecific expression patterns. Recently, a novel gene that appeared to be expressed specifically in neural and endocrine tissues was identified by us [6]. This so-called NSP-gene has recently been mapped by fluorescence in situ hybridization analysis to human chromosome 14q21-q22 [7]. Transcription of the gene was shown to result in overlapping mRNAs of $3.4 \mathrm{~kb}$ and $1.8 \mathrm{~kb}$. Northern blot analysis of various neural and endocrine tissues revealed differential expression of these NSP mRNAs. In the small cell lung carcinoma (SCLC) cell line NCI-H82, expression of high levels of a NSP transcript of $2.3 \mathrm{~kb}$ was found as well; so far, this transcript has been uniquely found in NCI-H82 cells. cDNAs corresponding to the $3.4 \mathrm{~kb}$ and $1.8 \mathrm{~kb}$ NSP mRNAs were isolated and nucleotide sequence analysis revealed that the $3.4 \mathrm{~kb}$ mRNA possessed an open reading frame for a protein of 776 amino acid residues (NSP-A) and that the $1.8 \mathrm{~kb}$ mRNA could code for a protein of 208 residues (NSP-C). The $2.3 \mathrm{~kb}$ NSP transcript in NCI-H82 cells appeared to have an open reading frame for 356 amino acids (NSP-B). Except for the first 20 amino-terminal residues, the deduced amino acid sequence of NSP-C was identical to that of NSP-A; furthermore, the common carboxy-terminal parts appeared to contain two large hydrophobic regions. Transfection of the complete coding sequences of the $3.4 \mathrm{~kb}$ transcript into COS-1 cells resulted in the production of a protein with an apparent molecular weight (Mw) of about $135 \mathrm{kDa}$ (NSP-A). On the basis of its deduced amino acid sequence, this protein was predicted to be highly negatively charged (calculated pI of 4.35), to be rich in proline and serine and to contain multiple potential phosphorylation sites. Such architectural features have been described for other NE proteins, e.g. the synaptic vesicle-associated protein amphiphysin. Amphiphysin is very acidic (predicted pl 4.39) and rich in proline residues; it contains potential sites for phosphorylation by various 
protein kinases, and possesses a hydrophobic stretch (potential membrane anchor) in its carboxy-terminal half [8]. Like amphiphysin, the two NSPs also lack a signal peptide. The predicted architectural similarities between NSP-A and synaptic vesicle-associated amphiphysin raised the question as to whether the postulated NSPs are associated with a particular compartment of the NE secretory pathway and, therefore, constitute novel components of it. Here, we report on the biosynthesis and biochemical characterization of NSP-A and NSP-C. In immunofluorescence as well as biochemical studies, the association of the NSPs with membranes of the ER was established. Evidence was obtained that membrane association is rather strong and, from analysis of deletion mutants of NSP-A, it appeared that the hydrophobic carboxy-terminal portion of the proteins is critical for the observed membrane binding. Finally, a search of nucleotide and protein databases was performed in an attempt to identify known sequences with similarity to NSP. NSP-related sequences were found in close proximity to the ERCCl locus on human chromosome $19 \mathrm{q} 13.3$ and in a human pancreatic islet-derived partial CDNA, suggesting that NSP is the prototype of a larger gene family.

\section{MATERIALS AND METHODS}

\section{Cell lines.}

Cell lines, used in this study, included the rat pancreatic islet tumor cell line RIN1027 $\mathrm{B} 2$, the rat medullary thyroid carcinoma cell line $6-23$, the mouse pituitary adenoma cell line AtT-20, the human lung carcinoma cell lines GLC-1, SCLC-21H, NCI-H82 and $\mathrm{NCl}-\mathrm{H} 520$, the monkey kidney cell line COS-1, and the pig kidney cell line PK(15). RIN1027 B2 cells were grown in DMEM/Ham's F12 (1/1) medium supplemented with $10 \%$ fetal bovine serum (Gibco-BRL). The origin and growth conditions of the other cell lines have been described before [6].

\section{NSP cDNA clones and derived DNA constructs for eukaryote expression.}

Cloning and analysis of NSP cDNAs corresponding to NSP mRNAs have been described previously [6]. pAB124 consists of a $3.0 \mathrm{kbp} \mathrm{NSP} \mathrm{CDNA}$, which is cloned into pUC18 (EcoRI site), corresponds to the $3.4 \mathrm{~kb} \mathrm{NSP} \mathrm{mRNA}$, and encodes NSP-A (776 amino acids). pAB49 and pAB60 consist of a $1.4 \mathrm{kbp} \mathrm{NSP} \mathrm{CDNA,} \mathrm{which} \mathrm{is}$ cloned into the ECORI site of pUC18 or PSP65, respectively; the CDNA corresponds to the $1.8 \mathrm{~kb}$ NSP mRNA and encodes NSP-C (208 amino acids). For expression in COS-1 cells of NSP cDNA constructs encoding NSP-A or NSP-C, the complete coding regions of corresponding cDNAs (isolated as Sall fragments from pAB124 or pAB60 respectively; one $S a / l$ site from polylinker) were cloned into the Xhol site of $\mathrm{PSVL}$. The resulting clones were named $p S V L-N S P-A$ and pSVL-NSP-C. PSVL-NSP-A DNA was used to generate deletion mutants. Mutants pSVL-NSP.AD424-end and pSVLNSP-A $\triangle 559$-end were obtained by inserting oligomer 5'-GTAGATCTACGC-3' into the KspI or oligomer 5'-TCGACATAGAGATCTCTATG-3' into the Xhol site, respectively. The sequence of the palindromic oligomers contained an in-frame stop codon and a $B g / I I$ site. It should be noted that as a consequence of the oligomer used, mutant PSVL-NSP-A $\triangle 559$-end has an oligomer-derived threonine at its carboxyterminus. Since upstream of the $K s p I$ and $X h o l$ sites, a unique BgllI site was present in pSVL-NSP-A, digestion of DNA of mutants pSVL-NSP-A $\triangle 424$ end and pSVL-NSP- 
A $\triangle 559$-end with $B g / I$ and subsequent religation resulted in the deletion mutants $p S V L$ NSP-A $\triangle 182-422$ and pSVL-NSP-A $182-557$, respectively (see Fig. 9). In mutant PSVL-NSP-A $\triangle 182-422$, there is one non-NSP residue (Tyr) at the site of fusion of the NSP parts, and in pSVL-NSP-A $\triangle 182-557$, there are two such residues (Ser-Met). In the pSVL constructs, expression of the NSP cDNAs is under control of the SV40 late promoter. Transfection was performed as described previously [6] and NSP-related protein biosynthesis was studied $36 \mathrm{~h}$ after transfection.

To transiently express NSP CDNAs under control of the middle promoter of the human cytomegalovirus, cDNAs were cloned into pHCMVA ${ }_{\mathrm{n}}$. pHCMV-NSP-C was obtained

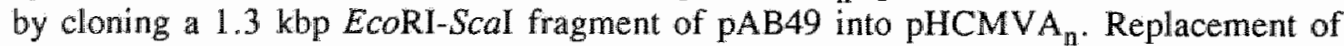
a $1.2 \mathrm{kbp}$ EcoRI-Sall fragment of pHCMV-NSP-C by a $3.0 \mathrm{kbp}$ EcoRI-SaII fragment of $\mathrm{pAB} 124$ resulted in $\mathrm{pHCMV}$-NSP-A. Transfection was carried out as described for the $\operatorname{COS}-1$ cells.

Expression of NSP cDNAs was also studied in PK(15) cells using recombinant vaccinia virus V.V.:T7 which encodes T7 RNA polymerase. In this system, expression of lipofected cDNAs is controlled by $T 7$ polymerase encoded by $V$.V.:T7. Procedures used here were described in detail previousiy [9]. NSP CDNAs encoding NSP-A or NSP-C were obtained by cloning appropriate NSP cDNA fragments downstream of the $T 7$ promoter in $\mathrm{pGEM}-3 \mathrm{Zf}(+)$ and the resulting clones were designated $\mathrm{pGEM}-\mathrm{NSP}-\mathrm{A}$ and $\mathrm{PGEM}-\mathrm{NSP}-\mathrm{C}$, respectively. RNA resulting from in vitro transcription of these clones were used in in vitro translation experiments in which a lysate of reticulocytes was used as a cell-free translation system.

\section{Antibodies, Western blot and immunoprecipitation analyses}

Rabbit polyclonal antiserum POL-1 was raised against BGal-NSP-A (6-776), a bacterially produced hybrid protein which consisted of BGal sequences fused to NSP-A sequences (residues 6-776) [6]. Control experiments revealed that POL-1 did not react with NSP-C. Rabbit antiserum POL 8 was raised against the synthetic peptide MQATADSTKMDCVWSNWKSQ, which represents the first twenty amino acid residues of deduced NSP-C; this amino acid sequence is not present in NSP-A. The synthetic peptide was purchased from Research Genetics; it was synthesized as a multiple antigen peptide, consisting of single units on a branching lysyl matrix using a solidphase peptide synthesis method [10]. Anti-NSP-A monoclonal antibodies (mabs) MON$160, \mathrm{MON}-161$, and MON-162 were obtained upon immunization of mice with partially purified BGal-NSP-A(6-776) using procedures as previously described [11]. In Fig. $1 \mathrm{~B}$, the protain regions harboring the epitopes recognized by the anti-NSP mabs have been depicted. Epitope region $A$ includes amino acid residues 174 to 337 and is recognized by MON-160 and MON-161. Epitope region $B$ includes residues 338 to 422 and is recognized by MON-162. MON-160, MON-161, and MON-162 also react with proteins encoded by rat and mouse NSP. Epitope mapping studies were performed using a panel of hybrid BGal-NSP hybrid proteins containing various portions of NSP-A [12]. Mabs RNL-2 and RNL-3, which were raised against NCIH82 lung carcinoma cells [13], have been shown to recognize NSP-A and NSP-B [13,6]. A mouse mab raised against SERCA2b [14], a $\mathrm{Ca}^{2+}-\mathrm{ATP}$ ase of the ER, was also used in this study.

Westem blot analysis was performed as described before [6,11,15). To label cells for immunoprecipitation analysis, culture medium was removed and cells were incubated 
for $30 \mathrm{~min}$ in methionine-free DMEM or in phosphate-free DME (GIBCO-BRL). Subsequently, cells were labelled for $6 \mathrm{~h}$ in the presence of $\left[{ }^{35} \mathrm{~S}\right]$ methionine (50 $\mu \mathrm{Ci} / \mathrm{ml}$, specific activity $>800 \mathrm{Ci} / \mathrm{mmol}$ ) or for $16 \mathrm{~h}$ in the presence of $\left[{ }^{32} \mathrm{P}\right]$ orthophosphate $(0.5 \mathrm{mCi} / \mathrm{ml}$, carrier-free, Amersham). After cell lysis, labelled NSPencoded polypeptides were immunoprecipitated using an appropriate antiserum or monoclonal antibody mixture, as previously described [6], and then analyzed by SDSPAGE [16], using a $7.5 \%$ (for NSP-A) or $12.5 \%$ (for NSP-C) polyacrylamide gel. To $\left[{ }^{32} \mathrm{P}\right]$-labelled lysates, pyrophosphate $(10 \mathrm{mM})$, microcystin $(200 \mathrm{nM})$, sodium vanadate $(200 \mu \mathrm{M})$, sodium fluoride $(10 \mathrm{mM})$ and $B$-glycerol $(20 \mathrm{mM})$ were added as phosphatase inhibitors before immunoprecipitation analysis.

\section{Phosphoamino acid analysis}

Phosphoamino acid analysis of ${ }^{32}$ P-labelled NSP-A was performed essentially as described by Kamps and Sefton, (1989) [17]. Briefly, ${ }^{32}$ P-labelled NSPs, immunoprecipitated from RIN1027 B2 or NCI-H82 cells, were size-fractionated via SDSPAGE and transferred electrophoretically onto Immobilon membranes (Millipore). After autoradiography, regions containing NSPs were excised and subjected to acid hydrolysis $\left(6 \mathrm{M} \mathrm{HCl}\right.$ for $1 \mathrm{~h}$ at $\left.110^{\circ} \mathrm{C}\right)$. After concentration by heat evaporation, phosphoserine, phosphothreonine, and phosphotyrosine were added as markers. Phosphoamino acids were then separated by two-dimensional electrophoresis on cellulose-coated TLC-plates (Merck) using the following conditions: first dimension, a $1 \mathrm{~h}$ run at $800 \mathrm{~V}$ in a $7.8 \%$ acetic acid/2.2\% formic acid buffer ( $\mathrm{pH} 1.5)$; second dimension, a $1 \mathrm{~h}$ run at $600 \mathrm{~V}$ in a $5 \%$ acetic acid/0.5\% pyridin buffer $(\mathrm{pH} 3.5$ ). Non-radioactive phosphoamino acid markers were visualised via incubation with ninhydrin.

\section{Immunofluorescence}

Transfected COS-1 cells and adherent NCI-H82 cells were grown for 48 h on poly-Llysine coated sterile glass slides. After removal of the medium, cells were first washed twice in phosphate-buffered saline (PBS), thereafter fixed in $4 \%$ paraformaldehydePBS for $10 \mathrm{~min}$, and then gently permeabilized for $2 \mathrm{~min}$ with PBS/0.02 \% saponin. Subsequently, cells were incubated for $1 \mathrm{~h}$ with appropriate antibodies. After three subsequent washes in PBS $/ 0.1 \%$ Tween, cells were incubated for $1 \mathrm{~h}$ with FITCconjugated rabbit anti-mouse or swine anti-rabbit (Dako) antiserum. For double-colourimmunofluorescence studies, a mixture of FITC-conjugated goat anti-mouse F(ab') antiserum (Dako) and TRITC-conjugated goat anti-rabbit antiserum (Sigma) was used; in control experiments, the species-specificity of these second antibodies had been checked. After three washes in PBS/0.1 \% Tween, preparations were mounted in Citifluor (Laborimpex). All experiments were performed at room temperature. Preparations were studied using a Zeiss Axiophot U.V. microscope with a Zeiss FITCor Omega dual bandpass-fillter. Pictures were taken on a Scotch CHROME 640-T film.

\section{Preparation and analysis of microsome fractions.}

For preparation of microsome fractions of RIN1027 B2 cells, a modification of the procedure described by Verboomen et al., (1992) [18] was used. Briefly, harvested cells were incubated for $10 \mathrm{~min}$ in a hypo-osmotic solution and then homogenized in a Dounce homogenizer using a tight-fitting glass pestle. Subsequently, homogenates were 
centrifuged at $10,000 \mathrm{~g}$ for $20 \mathrm{~min}$. The supernatant was further centrifuged at $100,000 \mathrm{~g}$ for $1 \mathrm{~h}$. The resulting microsome-containing pellet was resuspended in 0.25 $M$ sucrose. Protein concentrations were determined using the Biorad Protein Assay. To elucidate the distribution of NSPs after such cell fractionation, equal amounts of proteins or equal portions of fractions were size-fractionated by SDS-PAGE and studied by Western blot analysis using a mixture of MON-160, MON-161, and MON162. For further anallysis of the microsome fraction, equal amounts of the microsome fraction were again spun down at $100,000 \mathrm{~g}$ for $15 \mathrm{~min}$ and the pellets were resuspended in $0.5 \mathrm{M} \mathrm{KCl} / 0.25 \mathrm{M}$ sucrose, in $100 \mathrm{mM} \mathrm{Na}_{2} \mathrm{CO}_{3}$ (pH 11.5) or in $1 \%$ Triton X$100 /$ PBS. After a $30 \mathrm{~min}$ incubation on ice, samples were centrifuged at $100,000 \mathrm{~g}$ for 15 min. NSPs in pellets and supernatants were detected by Western blot analysis.

\section{RESULTS}

In vitro translation of NSP-A and -C RNA in a cell free system produces proteins of 135 and $23 \mathrm{kDa}$, respectively.

In previous studies, we have characterized cDNAs corresponding to three transcripts $(3.4,2.3$, and $1.8 \mathrm{~kb})$ of the novel NSP-gene [6]. Analysis of cDNAs corresponding to the physiological transcripts of $3.4 \mathrm{~kb}$ and $1.8 \mathrm{~kb}$ revealed that they have extensive sequence overlap starting at their 3'-ends. cDNAs corresponding to the $2.3 \mathrm{~kb}$ NSP transcript were not studied here, since the transcript has been found sofar only in cells. of the NCI-H82 lung carcinoma cell line. The interrelationships and relevant features of the three NSP transcripts are schematically represented in Fig. IA; characteristics of the corresponding deduced proteins, NSP-A, NSP-B and NSP-C are given in Fig. IB. No information was available as to what could be the function(s) of the NSPs. However, architectural resemblance to other NE proteins, such as for example the synaptic vesicle-associated protein amphiphysin [8], prompted studies which aimed at finding a possible association of the NSPs with a particular subcellular compartment and, in this way, at finding clues about possible functions of the proteins. To facilitate biochemical characterization of NSP-A and NSP-C and resolution of questions regarding their biosynthesis, post-translational modification, and subcellular localization, we first generated specific anti-NSP-A and anti-NSP-C antibodies (see Materials and Methods). The epitope regions recognized by the warious monoclonal anti-NSP-A antibodies are indicated in Fig. 1B. In the initial characterization of the primary translation products of the NSP-A and NSP-C transcripts, the corresponding RNAs were obtained via in vitro transcription of pGEM-NSP-A and pGEM-NSP-C DNA and these were subsequently translated using a reticulocyte lysate as a cell-free translation system. NSP A RNA appeared to encode a protein of about $135 \mathrm{kDa}$ (Fig. 2, lane 3), which could efficiently be immunoprecipitated by the anti-NSP-A polyclonal antibody POL-1 but not by POL-8, a monospecific anti-NSP $\cdots$ antiserum (data not shown). The electrophoretic mobility of the in vitro translation product appeared to be similar to that of the NSP-A protein immunoprecipitated from the human small cell lung carcinoma cell line NCI-H82 [6], from COS-1 cells expressing NSP-A upon transfection of pSVL-NSP-A DNA [6], and from V.V.:T7-infected PK(15) cells expressing NSP-A upon lipofection of pGEM-NSP-A DNA (Fig. 2, lane 5). This suggests that, in vivo, NSP-A is not subjected to extensive endoproteolytic 
processing or glycosylation. However, it should be noted that the NSP.A protein bands obtained through immunoprecipitation frequently showed some tailing towards slightly higher Mw products (discussed in detail below). As far as $N$-glycosylation is concerned, NSP-A contains two potential glycosylation sites. However, no detectable differences in electrophoretic mobility could be observed between NSP-A produced by NCI-H82 cells grown in the presence or absence of the $N$-glycosylation inhibitor tunicamycin (data not shown). In vitro translation of NSP-C RNA appeared to result in the production of a single protein of about $23 \mathrm{kDa}$ (Fig. 2, lane 2).

A

NSP-transcripts

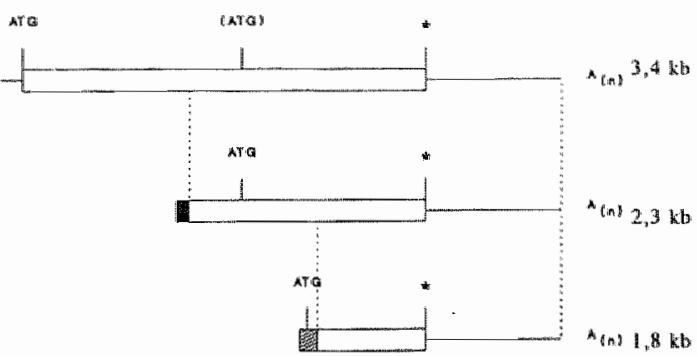

B

NSP-reticulons
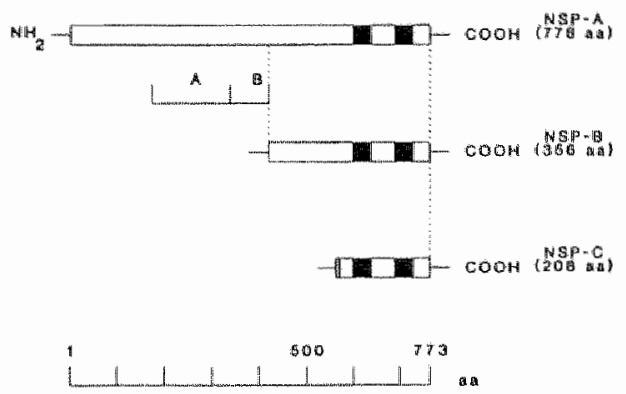

Figure 1. (A) Schematic representation of the NSP transeripts of $3.4 \mathrm{~kb}, 2.3 \mathrm{~kb}$ and $1.8 \mathrm{~kb}$. The open reading frames in the three cDNAs are represented as boxes; established $5^{\circ}$ - and $3^{\prime \prime}$-untranslated sequences as lines. Unique $5^{7}$-end sequences in the $2.3 \mathrm{~kb}$ and $1.8 \mathrm{~kb}$ transcripts are represented as a black or shaded box, respectively. Regions that are identical in the three transcripts are linked via broken lines. The relative positions of the predicted translation initiation and stop codons are indicated. The predicted translation initiation sites in the 2.3 and $1.8 \mathrm{~kb}$ transcript are not preceded by a stopcodon in frame. The predicted initiation codon of the $2.3 \mathrm{~kb}$ transcript is an internal ATG codon of the $3.4 \mathrm{~kb}$ transcript and is indicated between brackets in the latter transcript. It should be noted that, sofar, the $2.3 \mathrm{~kb}$ transcript is found only in lung carcinoma cell line $\mathrm{NCl}-\mathrm{H} 82161$.

(B) Schematic representation of the deduced domain structure of the three NSP-gene encoded proteins, NSP-A, NSP-B and NSP-C. The extent of the negatively charged domain in NSP-A and NSP-B is indicated; the hydrophobic domains in the carboxy-terminal regions of the three proteins are given as black boxes. Regions that are identical in the three proteins are linked via broken lines. The unique amino-terminal region (20 amino acid residues long) of NSP-C are represented by a shaded box. The total number of amino acid residues in the three deduced NSPs is given. Protein regions of NSP-A containing the epitopes recognized by the various anti-NSP monoclonal antibodies are indicated by numbered bars. Protein region A (residues 174-337) harbours the epitopes recognized by monoclonal antibodies MON-160 and MON-161, and protein region B (residues 338-422) the one recognized by MON-162.

\section{Biosynthesis and post-translational modification of NSP-A in vivo}

To characterize NSP-A produced in vivo, its biosynthesis was studied by immunoprecipitation (Fig. 3) and Western blot analysis (Fig. 4) in a number of cell types of human, rat, and mouse origin. Immunoprecipitation analysis using a mixture of monoclonal antibodies MON-160, MON-161 and MON-162, indicated that the $\left.{ }^{35} \mathrm{~S}\right]$ methionine-labelled NSPs synthesized in human cells (Fig. 3, lanes A and B) 


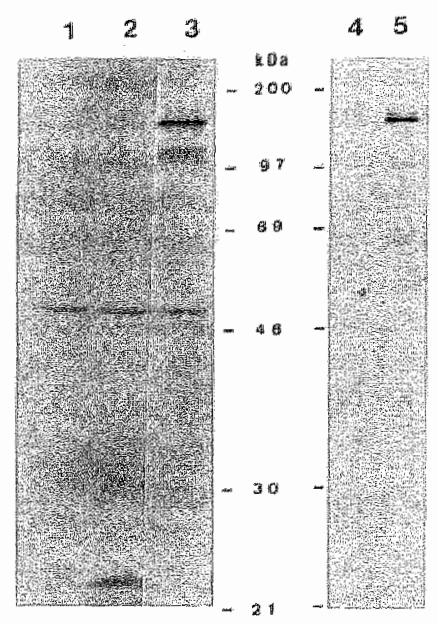

Figure 2. SDS-PAGE analysis of $\left[{ }^{35} \mathrm{~S}\right\}$ methionine-labelled NSPs synthesized in vitro using a cell-free translation system (lanes 1-3) or immunoprecipitated from PK(15) cells lipofected with pGEM-NSP-A DNA (lanes 4-5). Lane 1, no RNA added; lane 2,1 $\mu \mathrm{g}$ RNA transcribed from pGEM-NSP-C; lane 3, 1 $\mu \mathrm{g}$ RNA transcribed from pGEM-NSP A. For immunoprecipitation analysis, a mix.ure of monoclonal antibodies MON-160, MON-161 and MON-162 was used. Lane 4 , control PK(15) cells; lane 5, PK(15) cells lipofected with pGEM-NSP-A DNA. Molecular weight markers are indicated.

and mouse cells (Fig. 3, lane E) possessed similar Mw. Rat NSP-A expressed in pancreatic islet tumor cell line RIN1027 B2 (Fig. 3, lane C) or medullary thyroid carcinoma cell line 6-23 (Fig. 3, lane D), however, appeared to have a somewhat slower electrophoretic mobility ( $\mathrm{Mw}$ around $145 \mathrm{kDa}$ ). In the human non-small cell lung carcinoma cell line NCI-H520 (Fig. 3, lane F), which is known to lack NE features, no NSPs could be detected. The fact that the mixture of mabs raised against human NSP-A sequences seems to recognize homologous proteins in various species suggests that the NSPs contain domains that are conserved during evolution. The reason for the observed size differences between human and rat NSP-A remains to be established. As mentioned above and illustrated in Fig. 3, the NSP-A protein bands are somewhat diffuse and show tailling at the upper side. Also in experiments in which NSP-A was expressed at relatively high levels in COS-1 cells upon transfection of pSVL-NSP-A DNA [6], or in V.V.:T7-infected PK(15) cells upon lipofection of pGEM-NSP-A DNA [Fig. 2, lane 5), we obtained evidence that the diffuse NSP-A protein bands might in fact consist of two or more distinct bands differing only slightly in $\mathrm{Mw}$.

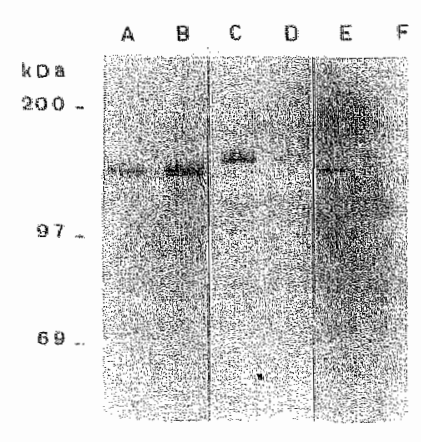

Figure 3. Immunoprecipitation analysis of the biosynthesis of NSP-A. $\left[{ }^{35}\right.$ S]methioninemabelled lysates of cells of human small cell lung carcinoma cell lines NCL-H82 (lane A) and $S C L C-21 H$ (lane $B$ ), the rat pancreatic islet tumor cell line RIN1027 B2 (lane C), the rat medullary thyroid carcinoma cell line 6-23 (lane D), the mouse pituitary adenoma cell line AtT20 (lane E), and the human non-small cell lung carcinoma cell line NCI-H520 (lawe F) were subjected to immunprecipitation and SDS-PAGE analysis. For immunoprecipitation of NSP-A, a mixture of monoclonal antibodies MON-160, MON-161, and MON-162 was used. Molecular weight markers are indicated. 
Together these results seemed to indicate that NSP-A occurs in various forms with slightlly different electrophoretic mobilities. This was further substantiated by results from Western blot studies, which were also performed to confirm, at the protein level, the Northern blot observation that NSP has a NE expression pattern [6]. A mixture of the anti-NSP-A mabs MON-160, MON-161 and MON-162 was used in the Western blot studies. In human pituitary gland, parathyroid (hyperplastic) gland, and medultary thyroid carcinoma, diffuse NSP-A protein bands were detected (Fig. 4, lanes A-C). It should be noted that the weak $68 \mathrm{kDa}$ protein band (Fig. 4, lane C) is most probably not related to NSP-A, since it was also detected in control experiments in which $\mathrm{Sp} 2 / 0$ myeloma supernatant was used instead of the mixture of mabs. In human liver, NSP-A could not be detected (Fig. 4, lane D). In similar analysis of tissue specimens of rat cerebellum and cerebrum (Fig. 4, lanes E and F), at least three distinct NSP-A protein bands were found. In rat liver, kidney and spleen, these proteins could not be detected (Fig. 4, lanes G-I).

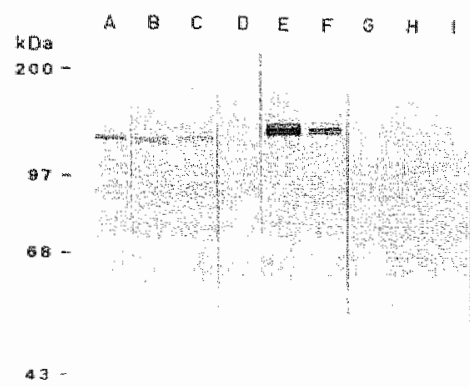

Figure 4. Western blot analysis of cell lysates of human and rat tissues with a mixture of monoclonal antibodies MON-160, MON-161, and MON-162. Anti-NSP immunoreactivity was visualized using a rabbit antimouse antiserum conjugated to alkaline phosphatase. Lane A) human pituitary gland; lane B) human hyperplastic parathyroid gland; lane C) human medullary thyroid carcinoma; lane D) human liver; lane E) rat cerebellum; lane F) rat cerebrum; lane G) rat liver; lane H) rat kidney; Lane 1) ral spleen. Molecular weight markers are indicated.

\section{Biosynthesis and post-translational modification of NSP-C in vivo}

To characterize NSP-C produced in vivo, its biosynthesis was studied by immunoprecipitation analysis of COS-1 cells transfected with pSVL-NSP-C DNA (Fig. 5A) and Western blot analysis of rat cerebellum and cerebrum (Fig. 5B). Monospecific antiNSP-C antiserum POL-8 was used; POL-8 was raised against a synthetic peptide consisting of the twenty amino-terminal residues of deduced NSP-C. From a $\left[{ }^{35} \mathrm{~S}\right]$ methionine-labelled lysate of transfected COS-1 cells, a single protein of about $23 \mathrm{kDa}$ was immunoprecipitated with POL-8 (Fig. 5A, lane A) but not with the corresponding preimmune serum (Fig. 5A, lane B). A similar single protein of $23 \mathrm{kDa}$ protein could be immunoprecipitated from the human small cell lung carcinoma cell line SCLC-21H (data not shown); this cell line has previously been shown to express the $1.8 \mathrm{~kb}$ NSP-C mRNA [6]. The $23 \mathrm{kDa}$ protein immunoprecipitated from the cell lysates comigrated in SDS-PAGE with NSP-C obtained by in vitro translation, suggesting no major posttranslational modifications. In Western blot analysis of rat cerebellum and cerebrum (Fig. 5B, lanes A and B) with POL-8, three protein bands were detected; one major band of about $23 \mathrm{kDa}$ and two minor bands of about $16 \mathrm{kDa}$. In similar Western blot analysis of lysates of human pituitary gland and human small cell lung carcinoma cell line GLC-1, only the $23 \mathrm{kDa}$ protein was detected (data not shown). The precise interrelationship between the 23 and $16 \mathrm{kDa}$ proteins remains to be established. 
M.

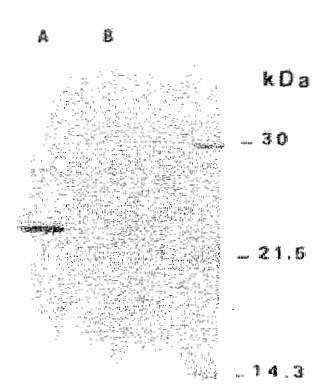

P

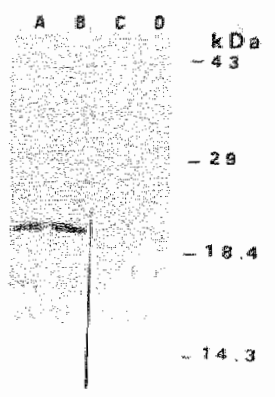

Fugure 5. Immunoprecipitation analysis of the biosynthes is of NSP-C. (A) $\left[{ }^{35} S\right]$ methionine-labelled lysates of COS-1 cells transfected with PSVL-NSP-C DNA (tanes A and B) were subjected to immunoprecipitation and SDS-PAGE analysis using rabbit antisenum POL-8 (lane A) of the corresponding preimmune serum (lane B). Radioactive molecular weight markers are indicated. (B) Western blot analysis of cell lysates of rat cerebellum (lames $\mathrm{A}$ and $\mathrm{C}$ ) and cerebrum (lanes $B$ and $D$ ) using rabbit anti-NSP-C antiserum POL-8. Anti-NSP-C immunoreactivity (lanes $A$ and $B$ ) was visualized using a swine anti-rabbit antiserum conjugated to alkaline phosphatase. As control serum, the corresponding preimmune serum was used (lanes $C$ and D). Non-radioactive molecular weight markers are indicated.

NSP-A, but not NSP-C, is highly phosphorylated, preferentially in serine residues A factor to be considered to explain the observed heterogeneity in the Mw of NSP-A is phosphorylation. To find out whether NSP-A and NSP-C are phosphoproteins, rat RIN1027 B2 cells, human NCI-H82 cells, and COS-1 cells transfected with either pSVL-NSP-A or pSVL-NSP-C DNA were cultured in the presence of [32P]phosphate and subsequently subjected to immunoprecipitation analysis (Fig. 6A). From lysates of rat RIN1027 B2 cells, human NCI-H82 cells and COS-1 cells transfected with pSVLNSP-A DNA, 32P-labelled NSP-A could be immunoprecipitated by a mixture of the anti-NSP-A mabs MON-160, MON-161 and MON-162 (Fig. 6A, lanes A, C, and D). Using a mixture of mabs RNL-2 and RNL-3, 32P-labelled NSP-A and a protein of about $45 \mathrm{kDa}$ were immunoprecipitated in the NCI-H82 cells (Fig. 6A, lane B). This $45 \mathrm{kDa}$ protein is most probably encoded by the presumably unique $2.3 \mathrm{~kb}$ NSP transcript [6] and we assume that it represents phosphorylated NSP-B. Immunoprecipitation analysis of 32P-labelled lysates of COS-1 cells transfected with pSVL-NSP-C DNA using the monospecific anti-NSP-C antiserum POL- 8 did not result in the detection of 32P-labelled NSP-C (data not shown). These results clearly establish that NSP-A and possibly NSP-B but not NSP-C are strongly phosphorylated. Furthermore, one may conclude that phosphorylation plays a role in the observed heterogeneity in Mw of NSP-A. To establish which amino acid residues in NSP-A is phosphorylated, 32P-labelled human and rat NSP-A proteins were immunoprecipitated and their phosphoamino acid compositions determined (Fig. 6B). In these experiments, phosphorylation of serine residues only could be demonstrated. We conclude from this study that serine residues are preferentially phosphorylated in NSP-A.

\section{NSP-A is associated with the endoplasmic reticulum}

We performed immunofluorescence experiments to elucidate the subcellular localization of NSP-A. Initial immunofluorescence studies of COS-1 cells transfected with PSVL-NSP-A DNA (Fig. 7A and B) using a mixture of anti-NSP-A mabs 


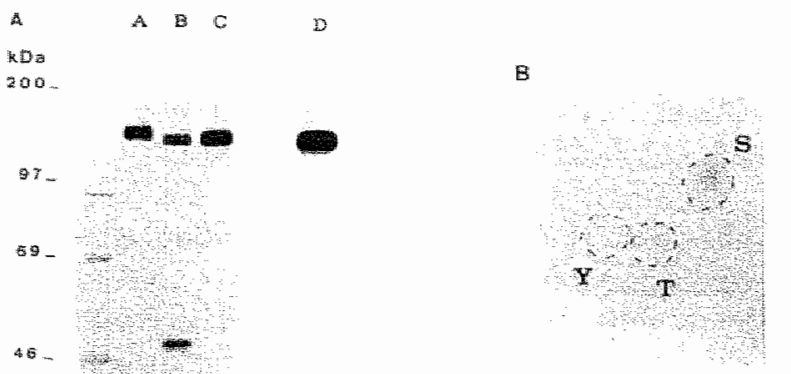

A. HUMAN

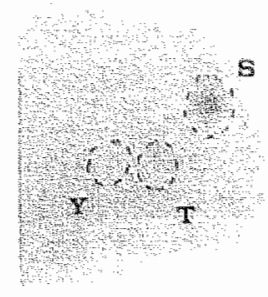

B. RAT

Figure 6. (A) [ $\left.{ }^{32} \mathrm{P}\right]$ phosphate-labelled lysates of RIN1027 B2 cells (lane A), cells of the human small cell lung carcinoma cell line NCI-H82 (lanes B and C), and COS-1 cells transfected with pSVL-NSPA DNA (lane D) were subjected to immunoprecipitation and SDS-PAGE analysis. Imnunoprecipitates shown in lanes $A, C$, and D were obtained with a mixture of monoclonal antibodies $M O N-160, M O N-$ 161, and MON-162. The immunoprecipitate shown in lane B was obtained with a mixture of monoclonal antibodies RNL-2 and RNL-3. Molecular weight markers are indicated. (B) Phosphoamino acid analysis of $\left[{ }^{32} \mathrm{P}\right]$ phosphate-labelled NSP-A inmunoprecipitated from lysates of human NCI-H82 cells (A) or rat RIN1027 B2 cells (B) using a mixture of antibodies MON-160, MON-161, and MON-162. Non-radiolabelled marker phosphoamino acids were visualized by spraying with ninhydrin and the $\left[{ }^{32} \mathrm{P}\right]$-labelled phosphoamino acids by autoradiography. The relative positions of phosphotyrosine $(\mathrm{Y})$, phosphothreonine $(\mathrm{T})$ and phosphoserine $(\mathrm{S})$ are indicated.

MON-160, MON 161 and MON-162, revealed an intense perinuclear staining and a uniform staining of a peripheral, lace-like network. In non-transfected COS-1 cells, no immunostaining could be demonstrated (data not shown). At higher magnification, the lace-like pattern of the NSP-A immunoreactivity appeared to exhibit a punctate pattern (Fig. 7B). In various NE cell lines, identical intense perinuclear staining and uniform staining of a peripheral, lace-like network was observed, suggesting that the observed pattern represents the physiological subcellular distribution of NSP-A. As an illustration, the results obtained with adherent cells [19] of the human small cell lung carcinoma cell line NCI-H82 are shown (Fig. 7C), Staining of the perinuclear region and of a peripheral, lace-like network suggested that NSP-A might be associated with the ER [20]. To investigate this possibility, collocalization studies were performed with a marker protein for membranes of the ER. As marker protein, $\mathrm{Ca}^{2+}$-ATPase SERCA2b, which is a known component of membranes of the ER [14,21], was selected. Immunofluorescence analysis was performed on non-transfected COS-1 cells (data not shown) or COS-1 cells transfected with pSVL-NSP-A DNA (Fig. 7D) using a mouse monoclonal anti-SERCA2b antibody. In both cases, strong perinuclear staining and punctate staining of lace-like structures was observed and the staining patterns were highly similar, if not identical, to the ones that were observed in the immunofluorescence studies of COS- 1 cells transfected with pSVL-NSP-A DNA using anti-NSP-A antibodies (Fig. 7A). To establish that the observed NSP-A- and SERCA2b-like immunoreactivities are colocalized, double-colour immunofluorescence analysis of COS-1 cells transfected with pSVL-NSP-A DNA was performed; the mouse monoclonal anti-SERCA2b antibody and the rabbit polyclonal anti-NSP-A antiserum 
POL-1 were used; NSP-A-like reactivity was visualized in spectrum red and that of SERCA2b, in spectrum green. As can be seen in Figs. $7 E$ and 7F, NSP-A and SERCA2b are clearly colocalized in the lace-like network. These results strongly suggest that NSP-A is associated with the ER.

\section{$N S P-A$ and $-C$ are associated with membranes of the endoplasmic reticulum through interaction of their carboxy-terminal regions}

The immunofluorescence evidence showing NSP-A to be associated with the ER and our previous observation that the deduced NSP-A and NSP-C proteins exhibit extensive overlap (of the deduced 208 amino acid residues of NSP-C, only the first twenty amino-terminal residues are not found in NSP-A) suggest that NSP-C could also be associated with the ER. To test this possibility, COS-1. cells transfected with pSVLNSP-C DNA were also studied by immunofluorescence analysis. Monospecific antiNSP-C antiserum POL-8 was used. These studies revealed strong staining of the perinuclear region as well as uniform staining of a lace-like network (Fig. 8A and B), like that observed in COS-1 cells transfected with pSVL-NSP-A DNA (cf. Fig. 7A and B). In non-transfected COS-1 cells, no immunostaining was observed with the antiNSP-C antiserum (data not shown). These results suggest that, like NSP-A, NSP-C seems to be associated with the ER. The immunological evidence for the ER association of NSP-A and NSP-C raised the question of what the mechanism for this might be. Since both proteins have been predicted to possess the same hydrophobic carboxy-terminal region with multiple, potential transmembrane domains, one likely possibility is that $\mathrm{ER}$ association is mediated through interaction with this region. To test this possibility, mutants of NSP-A were made (Fig. 9) and proteins encoded by these could be detected by either the polyclonal POL-1 antiserum or the mabs. Two of these NSP-A mutants, NSP-A $\triangle 424$-end and NSP-A 4559 -end, were truncated at their carboxy-termini and lacked the predicted hydrophobic region. Two other NSP-A mutant proteins, NSP-A $\triangle 182-422$ and NSP-A $\Delta 182-557$, were deletion mutants that lacked portions of the negatively charged domain. Expression and subcellular localization of the various mutant proteins were studied upon transfection of COS-1 cells with corresponding DNA constructs that allowed expression of the mutated NSPA sequences under control of the SV40 late promoter. Immunoprecipitation analysis of 35 S-labelled lysates of transfected COS- 1 cells with appropriate anti-NSP-A antibodies indicated that, in all four cases, mutant NSP-A proteins were synthesized. Cells transfected with pSVL-NSP-A 4424 -end, pSVL-NSP-A $\triangle 559$-end, pSVL-NSP-A $\Delta 182$ 422, or pSVL-NSP-A $\triangle 182-557$ DNA appeared to express NSP-A-related proteins of around $70 \mathrm{kDa}, 105 \mathrm{kDa}, 80 \mathrm{kDa}$, and $45 \mathrm{kDa}$, respectively (data not shown). Immunofluorescence analysis of COS-1 cells transfected with pSVL-NSP-A 424 -end (Fig. 8C) or pSVL-NSP-A $\triangle 559$-end (Fig. 8D) DNA using a mixture of the three antiNSP-A mabs revealed a diffuse cytoplasmic staining with highest intensity in the perinuclear region. Immunofluorescence analysis of these cells with the anti-SERCA2b antiserum revealed staining of a lace-like structure similar to that shown in Fig. 7D. In COS-1 cells expressing deletion mutants NSP-A $182-422$ (Fig. 8E) or NSP-A 18182 557 (Fin. 8F and G), the NSP-like immunoreactivity (detected with POL-1), with both intense perinuclear staining and uniform staining of a peripheral, lace-like network, was similar to that observed in COS-1 cells transfected with wild-type pSVL-NSP-A DNA (cf. Fig. 7A and B). These results strongly suggest that both NSPs are 
interacting with the ER by means of their common carboxy-terminal regions. The multiple predicted transmembrane domains in these carboxy-terminal regions are most likely involved in the strong binding to the ER membrane (demonstrated below). Because of their association with the ER and to reflect that they are found on membranes, we will refer to NSP-A and NSP-C as reticulons.

\section{Biochemical evidence that reticulons are strongly associated with membranes of the endoplasmic reticulum}

To define further the association of the reticulons with the ER, the distribution of NSPA over subcellular fractions of RIN1027 B2 cells was studied. When equal amounts of proteins were analyzed, virtually no NSP-A was found in the $10,000 \mathrm{~g}$ pellet (Fig. 10, lane 1) and the $100,000 \mathrm{~g}$ supernatant (Fig. 10, lane 3). Most NSP-A was found in the $100,000 \mathrm{~g}$ microsome pellet (Fig. 10, lane 2). When equal portions of the three fractions were analyzed, most of the NSP-A was found in the microsome pellet and, to a lesser extent, in the $100,000 \mathrm{~g}$ supernatant; only small amounts were found in the $10,000 \mathrm{~g}$ pellet (data not shown). These results indicate that a significant portion of NSP-A is associated with microsomes. To obtain further insight into this, we studied the association of NSP-A with microsomes by treating RIN1027 B2 microsome fractions under various conditions as indicated in Fig. 10. After treatment, samples were centrifuged and aliquots of the pellets and supernatants were tested by Western blotting for the presence of NSP-A. After incubation of the microsome fraction with $0.5 \mathrm{M} \mathrm{KCl}$ and subsequent centrifugation, almost all the NSP-A was found in the pellet, not in the supernatant (Fig. $10 ; 0.5 \mathrm{M} \mathrm{KCl}$ ). This indicates that NSP-A is strongly bound to the membranes and cannot be stripped off in this way. Similar analysis after incubation of the microsomes with $100 \mathrm{mM} \mathrm{Na} 2 \mathrm{CO}_{3}(\mathrm{pH} 11.5)$ revealed that, also under these conditions, almost all the NSP-A was found in the pellet (Fig. $10 ; \mathrm{pH} \mathrm{11.5)}$. This result indicates a strong association of the protein with the membranes, since treatment of microsomes with $100 \mathrm{mM} \mathrm{Na}_{2} \mathrm{CO}_{3}$ is known to make microsome membranes permeable and to cause the release of intraluminal ER proteins [22]. Treatment of the membrane fractions with $1 \%$ Triton $X$ - 100 resulted in the solubilization of all the NSP-A (Fig. 10;1\% X-100). Altogether, our results seem to indicate that NSP-A occurs tightly associated with microsome membranes and that the hydrophobic regions in the carboxy-terminal region are likely to be involved as membrane-anchoring structures. As identical membrane anchoring structures are also present in NSP-C, it is reasonable to assume that NSP-C is also anchored to membranes.

\section{Identification of NSP-related sequences in the human genome}

We have compared the NSP cDNA sequences to database DNA sequences (BLASTN; [22]). Similarly, we compared the deduced amino acid sequences of the NSPs with known protein sequences (BLASTP; [23]). Such comparative analyses resulted in the identification of rat CDNA clone $\mathrm{Cl}-13$ [24], which presumably corresponds to rat NSP (for further details, see Discussion). Furthermore, a number of partial human NSP cDNA sequences were identified in the database files. Using an alternative and more sensitive screening approach (TBLASTN; [23]), we subsequently searched for amino acid sequence similarity between NSP-A and the amino acid sequences that are obtained when database nucleotide sequences are translated in six reading frames. 

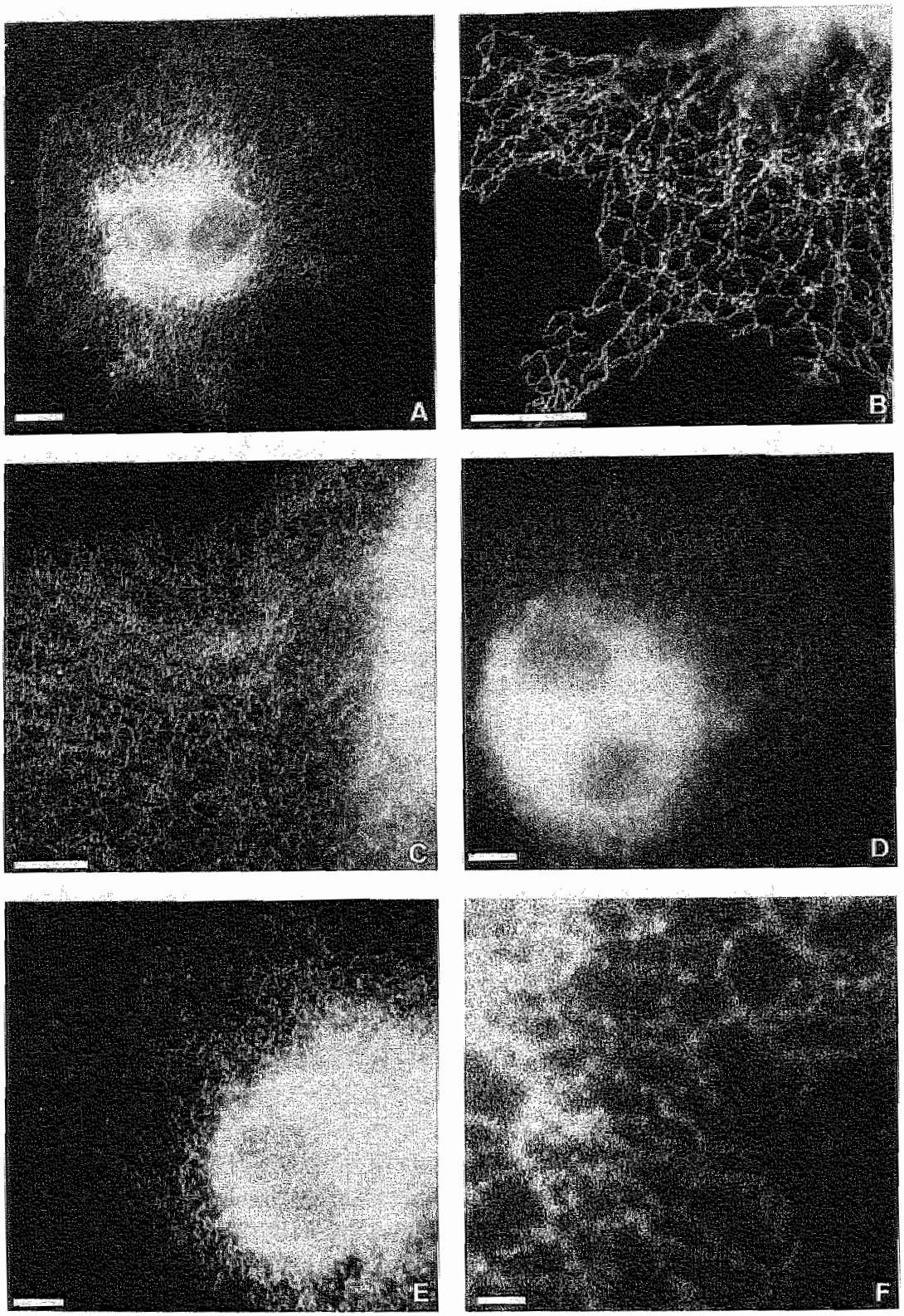

Figure 7. Immunocytochemical localization of NSP-A to the endoplasmic reticulum and colocalization with SERCA2b at the light microscopic level. The figure shows COS-l cells transfected with pSVLNSP A DNA (A and D-F), with PHCMV-NSP-A DNA (B), or NCI-H82 human lung carcinoma cells (C). Cells were stained with the mixture of MON-160, MON-161, and MON-162 (A-C), with antiSERCA2b monoclonal antibody (D) or with a mixture of anti-NSP-A antiserum POL-1 and the mouse monoclonal anti-SERCA2b antibody ( $E$ and $F$ ). Immunoreactivities (A-D) were visualized using FITCconjugated rabbit anti-mouse antiserum. In the cases of double-colour immunofluorescence analysis, polyclonal rabbit anti-NSP-A immunoreactivity was visualized by TRITC-conjugated goat anti-rabbit antiserum and that of mouse monoclonal anti-SERCA2b by FITC-conjugated goat anti-mouse antiserum. Note the lace-like pattern of the NSP-like immunoreactivity and the punctate pattern, at higher magnification. Bars: $10 \mu m(A-E) ; 1 \mu \mathrm{m}(\mathrm{F})$. For colour illustration of $\mathrm{E}$ and $\mathrm{F}$ see $\mathrm{p} 157$. 

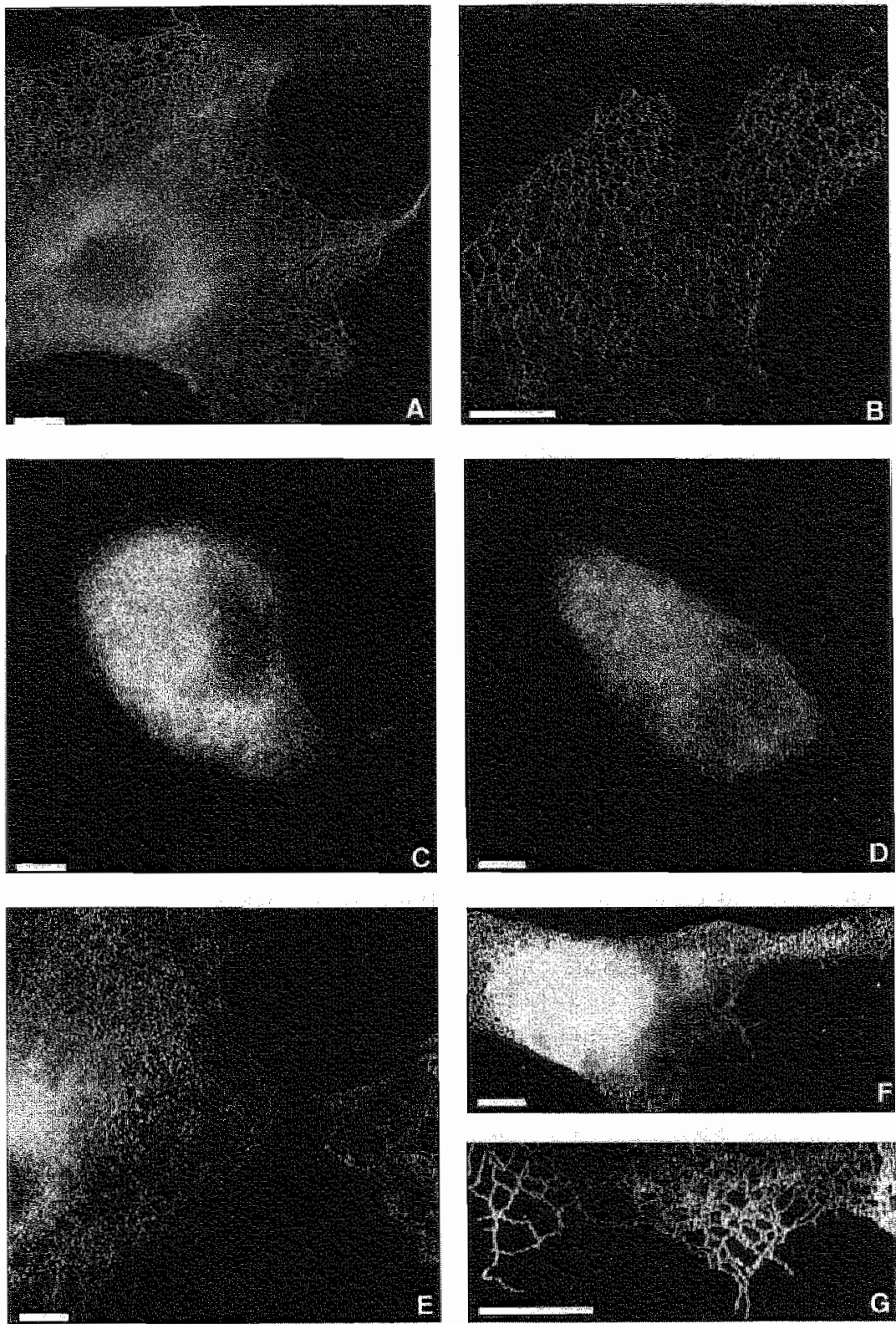

Figure 8. Immunocytochemical localization of NSP-C and mutants of NSP-A. The figure shows COS1 cells transfected with pSVL-NSP-C DNA (A and B), pSVL-NSP-A $\triangle 424$-end DNA (C), pSWL-NSPA $\triangle 559$-end DNA (D), pSVL-NSP-A $182-422$ DNA (E), or pSVL-NSP-A $182-557$ DNA (F and G). Cells were stained with the rabbit anti-NSP-C antiserum POL-8 ( $A$ and $B$ ), a mixture of monoclonal antibodies MON-160, MON-161, and MON-162 (C and D), or the polyclonal rabbit anti-NSP-A antiserum POL-1 (E-G). Immunoreactivities were visualized by immunofluorescence cytochemistry using FITC-conjugated swine anti-rabbit or rabbit-anti-mouse antiserum. Note that cells expressing NSP-C (A and B) display a similar lace-like pattern as cells expressing NSP-A (compare Figs. $7 \mathrm{~A}$ and 7B) and that in cells expressing NSP-A mutants that lack the hydrophobic domains, the lace-like pattern observed for NSP-A and $-C$ is not present (C and D). Bars: $10 \mu \mathrm{m}$. 


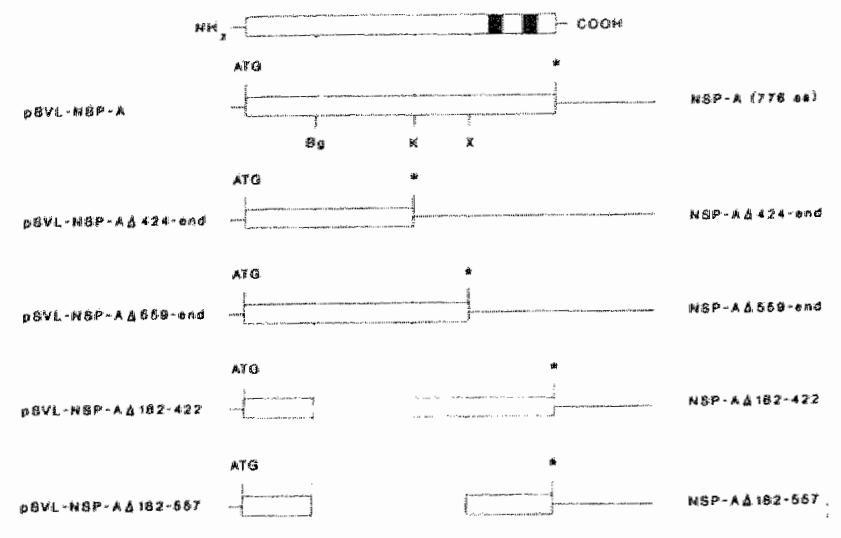

Figure 9. Schematic representation of NSP-A deletion mutants. At the top of the figure, the NSP-A protein with two hydrophobic regions (black boxes) is depicted. directly beneath $\mathrm{in}_{*}$, the corresponding open reading frame of pSVLNSP-A DNA with the relative position of restriction nuclease cleavage sites relevant to construct the NSP-A deletion mutants. Stop codons are indicated by asterisks. The names of the DNA constructs encading the various deletions mutants are given at the right side, the names of the corresponding (mutant) proteins on the left side of the figure. $\mathrm{Bg}, \mathrm{Bg} I \mathrm{I} ; \mathrm{K}, \mathrm{KpnI}$; X, Xhal.

By this approach, we found indications of the existence of two NSP-like genes, which we will call here NSP-like genes I and II. Sequences of NSP-like gene I were found in a sequenced DNA region of about $106 \mathrm{kbp}$ around the ERCCl locus on human chromosome 19q13.3 [25]. In that $106 \mathrm{kbp}$ DNA region, we found stretches of DNA with coding capacity for protein sequences similar to those in the carboxy-terminal regions of the NSP-A and NSP-C proteins, which these two proteins have in common; about $50 \%$ sequence similarity at the deduced amino acid level and about $57 \%$ at the nucleotide level. These DNA stretches in the predicted NSP-like gene I appeared to correspond to the six 3 '-end NSP exons that we have identified in the NSP-gene, which has a size of about $300 \mathrm{kbp}$ [7]. The newly identified sequences of this NSP-like gene I appeared to have the same exon distribution as the six corresponding NSP exons. Moreover, the protein that could be deduced from the open reading frame of these exons displayed similar architectural features to NSP-A and NSP-C, including the hydrophobic domains by which this putative protein may associate with membrane structures as do the NSPS. Sequences of NSP-like gene II were identified as the deduced amino acid sequence of a small human pancreatic islet-derived cDNA clone (GenBank accession number T10889; [26]) was found to display strong sequence similarity to NSP-encoded sequences. Relative to NSP, sequence similarity at the deduced amino acid level was about $56 \%$ and, at the nucleotide level, about $62 \%$. An alignment of NSP-C and the available deduced amino acid sequences of these two NSP-like genes is shown in Fig. 11. Northern blot analysis revealed that both NSP-like genes are transcribed into two mRNAs. Analysis with a probe specific for NSP-like gene I revealed transcripts of $2.4 \mathrm{~kb}$ and $1.4 \mathrm{~kb}$, whereas with a probe specific for NSP-like gene II, transcripts of $2.6 \mathrm{~kb}$ and $2.1 \mathrm{~kb}$ were found (data not shown). By fluorescence in situ hybridization experiments and Southern blot analysis of a panel of human $x$ mouse hybrid cell lines, we have recently mapped the NSP-gene to region q21-q22 of the long arm of chromosome 14 [7]. The NSP-like gene I is apparently located on human chromosome $19 q 13.3[25]$, whereas the chromosomal localization 


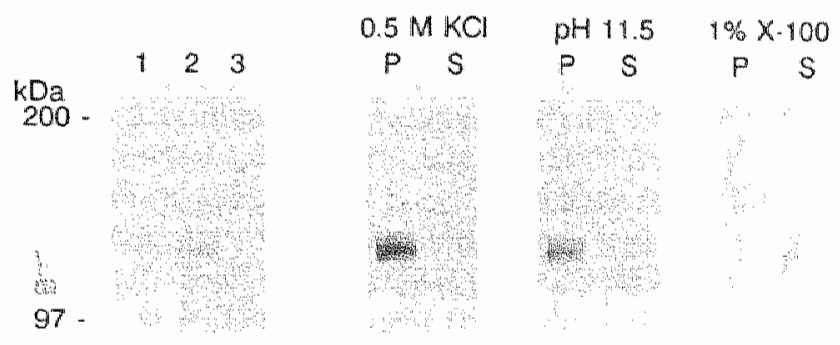

Figure 10. Western blot analysis of NSP-A distribution after cell fractionation of RIN1027 B2 rat pancreatic islet tumor cells and upon treatment of the microsome fractions under various conditions. Fractions obtained were analyzed by Western blotting using a mixture of monoclonal antibodies MON$160, \mathrm{MON}-161$, and $\mathrm{MON}-162$. Lane $1 \mathrm{y}: 10,000 \mathrm{~g}$ pellet; lane 2) $100,000 \mathrm{~g}$ pellet (microsomes); lane 3) $100,000 \mathrm{~g}$ supernatant. Microsome fractions were also treated under various conditions as indicated and, after subsequent centrifugation, the $100,000 \mathrm{~g}$ pellets (P) and remaining supernatants (S) were analyzed by Western blotting. Molecular weight markers are indicated.

of NSP-like gene II remains to be established. Although their full characterization remains to be performed, the results obtained so far strongly support the conclusion that the human genome contains at least two NSP-related genes. The established features of the reticulons, NSP $-A$ and NSP-C, and the predicted characteristics of products encoded by the two NSP-like genes, make this novel gene family intriguing in the context of the elaborate endomembrane system of the eukaryotic cell.

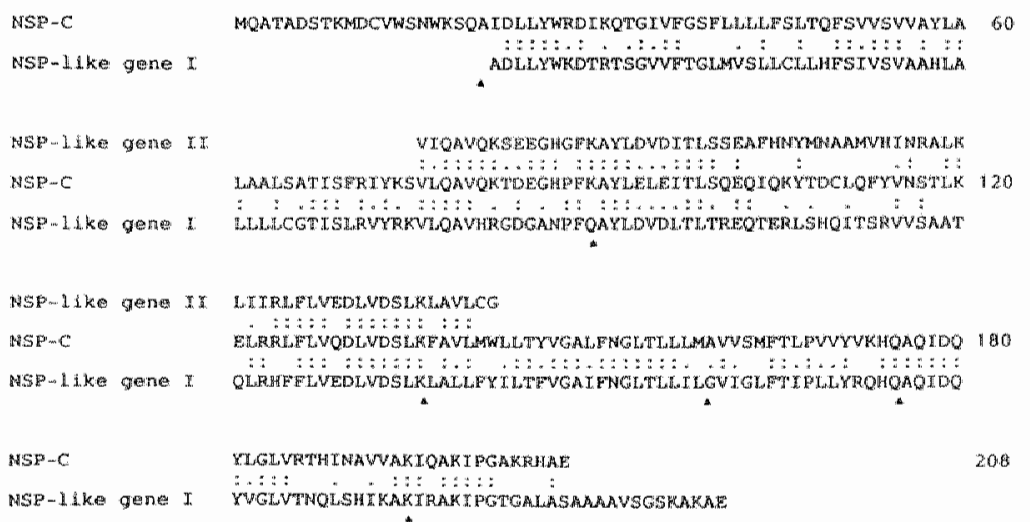

Figure 11. Alignment of partial amino acid sequences of predicted translational products of the putative NSP-like genes I and II relative to the NSP gene encoded NSP-C. Sources for sequence data: NSP-like gene I (Martin-Gallardo et al., 1992; accesssion number M89651); NSP-like gene II (Bell and Takeda, 1993; accession number T10889); NSP-C (Roebroek et al, accession number L10335). Triangles (4) indicate the relative positions of exon junctions in NSP and NSP-like gene II. Identical amino acid residues in corresponding positions relative to NSP-C are marked by colons (:); conserved substitutions in the NSP-like sequences relative to NSP-C are marked by periods (.). 


\section{DISCUSSION}

In this study, we used specific monoclonal and polyclonal anti-NSP antibodies to study biosynthesis, post-translational modification, and subcellular localization of proteins encoded by the novel NSP-gene. Consistent with previous Northern blot studies [6], which revealed that NSP codes for two $3^{\prime}$-end overlapping transcripts in NE cells, of 3.4 and $1.8 \mathrm{~kb}$, respectively, we demonstrate that these code for two proteins, NSP-A and NSP-C, which have identical carboxy-terminal regions. It should be noted that, only in the small cell lung carcinoma cell line NCI-H82, a third NSP transcript was found $(2.3 \mathrm{~kb})$ and that it appears to code for NSP-B; since NSP-B probably represents an aberrant NSP product [6], its characterization was not further addressed here. In in vitro translation experiments using a reticulocyte cell-free system, we found that the $3.4 \mathrm{~kb}$ and $1.8 \mathrm{~kb}$ RNAs coded for proteins with electrophoretic mobilities in SDSPAGE of about $135 \mathrm{kDa}$ (NSP-A, 776 amino acid residues) and $23 \mathrm{kDa}$ (NSP-C, 208 amino acid residues), respectively. The size of the NSP-A protein as estimated from its observed electrophoretic mobility was unexpectedly high. From nucleotide sequence data of the corresponding NSP transcript, it was deduced that the NSP-A protein consists of 776 amino acids with a calculated $\mathrm{Mw}$ of $84 \mathrm{kDa}$, differing significantly from the observed electrophoretic mobility. It is assumed that the particular amino acid composition, especially the relatively high number of negatively charged residues, is responsible for the observed anomalous migration behavior of the NSP-A protein during electrophoresis.

In previous studies [6], we found that radiolabelled NSP-A immunoprecipitated from cell lysates also had a electrophoretic mobility in SDS-PAGE of about $135 \mathrm{kDa}$, indicating that no major post-translational modifications of the NSP-A protein occur in the cell. In this context, it should be mentioned that the protein produced by NSP-A RNA in in vitro translation experiments comigrated with the NSP-A protein immunoprecipitated from human NE cell lines, COS-1 cells transfected with pSVLNSP-A DNA, or V.V.:T7-infected PK(15) cells lipofected with pGEM-NSP-A DNA. Results of Western blot studies, however, especially those of rat brain tissue, clearly pointed towards some heterogeneity of NSP-A and suggested that NSP-A might occur in various, slightly modified forms. The observed heterogeneity is most likely due to phosphorylation of NSP-A which, as we demonstrated, is highly phosphorylated in serine residues. Our proposition that the heterogeneity in NSP-A is due to phosphorylation is supported, furthermore, by the observation that an antiserum, which was known to recognize phosphoserine and phosphothreonine residues, did react in Western blot analysis of rat cerebellum with two higher $\mathrm{Mw}$ isoforms of the $145 \mathrm{kDa}$ NSP-A triplet but not with the lowest $M w$ protein band (van de Velde, unpublished observations). The phosphorylation of serine residues is in good agreement with the presence of multiple potential phosphorylation sites on serine or threonine by protein kinase C or casein kinase II in NSP-A [6].

The NE expression pattern of the NSP-A protein observed in the Western blot and immunoprecipitation studies is consistent with results from previous Northern blot studies [6]. Recently, we showed that NSP-A is expressed in various regions of the brain (e.g. cerebellar Purkinje cells, cerebral cortex, hippocampus, substantia nigra,
colliculus superior), in parathyroid gland, pituitary gland, pancreatic islets, and adrenal
medulla [12]. medulla [12]. 
As far as NSP-C is concerned, the major product of the $1.8 \mathrm{~kb} \mathrm{NSP}-\mathrm{C}$ mRNA is a 23 $\mathrm{kDa}$ protein and, unlike NSP-A, NSP-C is not phosphorylated; also no heterogeneity in size was observed. In a recently released update of the EMBL/GenBank nucleotide database, we found that the nucleotide sequence of rat $\mathrm{cDNA}$ clone $\mathrm{Cl}-13$ (accession number X52817; release annotation 16-MAR-1993; [24]) is very similar (83\% at the nucleotide level; $95 \%$ at the amino acid level) to that of the human $1.8 \mathrm{~kb}$ NSP (NSPC) transcript. cDNA clone $\mathrm{Cl}-13$, which was about $1.5 \mathrm{kbp}$ long, had been isolated by hybridization to a tropomyosin probe, however, no significant sequence similarity appeared to exist between the deduced protein sequence of $\mathrm{Cl}-13$ and tropomyosin. From Northern blot analysis, it has been reported that the gene corresponding to cDNA clone $\mathrm{Cl}-13$ is developmentally regulated and expressed solely in neuronal tissue [23]. Because of its high degree of sequence similarity to NSP-C and its similar expression pattern to NSP-C [6], it is reasonable to assume that rat cDNA CI-13 corresponds to rat NSP, although the following observation might argue against this assumption. The protein that can be deduced from the open reading frame of rat cDNA clone Cl-13 is 59 amino acids longer than that of the NSP-C described by Roebroek et al. (1993) [6]. This is due to differences in translation initiation and termination. However, electrophoretic mobilities of the human NSP-C proteins, encoded by cloned as well as endogenous NSP sequences were similar to that of endogenous rat NSP-C, if not identical. As yet, we have no explanation for this apparent discrepancy.

Independent experimental approaches in this study provide evidence that suggests an association of the NSPs with the ER: i) immunofluorescence analyses of both NSP-A and NSP-C show the characteristic reticular staining pattern, most intense in the perinuclear region and extending throughout the cytoplasm; ii) NSP-A immunostaining clearly colocalizes with the SERCA2b Ca ${ }^{2+}$ pump, a marker protein for membranes of the ER; iii) endogenous NSP-A is predominantly found in the microsomal fraction and appears to be tightly associated with membranes in this fraction. To the best of our knowledge, the NSP-A and NSP-C proteins represent the first examples of ER proteins with a NE-restricted expression pattern. To reflect this characteristic ER localization, the name reticulons is proposed for NSP-A and NSP-C.

Analysis of NSP-A mutants established that the common carboxy-terminal regions of the two proteins direct the association with and the retention on membranes of the ER. This raises the question as to whether a particular retention signal may be responsible for targeting the reticulons to membranes of the $\mathbb{E R}$. Unlike the targeting signals for soluble ER proteins, in which the carboxyterminal sequence KDEL has been identified as the ER retention motif $[27,28]$, the targeting signals of membrane proteins of the ER are only starting to be elucidated. Some ER type I transmembrane proteins, the prototype of which is the adenoviral E3/19K protein, contain an ER targeting motif consisting of two lysine residues at the -3 and either the -4 or -5 position from the carboxy-terminus [29], serving as a retention signal [30]. Although the NSPs contain three basic residues (Lys-Arg-His) at the -5 to -3 position, they do not strictly fulfill this criterion. It thus remains to be established whether the hydrophobic carboxyterminal part of the molecule actually retains the reticulons in the ER rather than anchoring the proteins in the membrane. it is however of interest to note that the postulated NSP-like gene I encodes a protein with a potential ER retention signal (LysAla-Lys-Ala-Glu) (Fig. 10), as mentioned above. Even less is known about the mechanism by which proteins without a hydrophobic signal sequence, like NSP-A and 
NSP-C, are inserted and retained in the membrane of the ER. Recently, the ER targeting signal of cytochrome b5 was identified as a carboxy-terminal, hydrophilic sequence of ten amino acids, adjacent to a hydrophobic membrane-anchoring region [31]. However, neither in previously published other ER membrane proteins synthesized on free ribosomes [31], nor in the NSPs, can a homologous sequence be found. Although it is not unreasonable to assume that the two large hydrophobic domains in the common region are involved in ER membrane anchoring, we must conclude that the sequences in the reticulons that are responsible for retention remain to be elucidated. With respect to their possible functions, the reticulons possess interesting structural features; each contains a unique amino-terminal domain linked to a common membrane-anchoring, carboxy-terminal domain. As already mentioned above, the unique domain of NSP-A is large, negatively charged and can occur in a phosphorylated form through serine phosphorylation, whereas the unique domain of NSP-C is only twenty amino acids long and, as yet, without any known characteristics. One could speculate that the large amino-terminal domain of NSP-A might interact with other specific proteins or could have a receptor function to which particular ligands may bind. On the other hand, NSP-C could be a membrane-anchoring structure for other proteins and, if so, this is likely to be controlled by the NSP-C-specific sequences in its small amino-terminal domain. In this context it is of interest to note that immunofluorescence analysis of rat cerebellum with anti-NSP-A mabs revealed strong immunostaining of Purkinje cells; in the perikaryon, the extensive dendritic tree and the axon. As neuronal rough ER is only considered to be present in the perikaryon and the proximal regions of dendrites and axon, while smooth ER extends throughout the whole dendritic tree and the whole axon [32,33], the association of NSP-A with neuronal rough and smooth ER can be proposed. This remains to be established by further biochemical and electron microscopic analysis. Functionally, the axonal smooth ER is considered to play a major role in the rapid anterograde transport of enzymes and of a variety of membrane macromolecules to be incorporated into the axolemma and synaptic vesicles, in the formation of synaptic vesicles, and in the sequestration of calcium $[1,33-35]$. Because of their likely association with the rough as well as the smooth ER, the reticulors might play some role in transport processes or in the regulation of intracellular calcium levels. In light of the fact that computer analysis of the deduced amino acid sequences of the reticulons predicts them to have two hydrophobic regions encompassing two potential transmembrane domains [6] and in agreement with the observation that NSPs tend to form aggregates [13], one could speculate that the reticulons are associated with the ER membranes as channel-like complexes. Whatever the function of the novel NSP-gene family might be, the observed amino-terminal structural diversity in the reticulons and the discovery of two NSP-related gene is likely to reflect some degree of functional diversity in the products of this novel gene family.

\section{Acknowledgements}

We thank $\mathrm{Dr} H$ Van den Berghe for his continuous support. Cell line RIN1027 B2 was kindly provided by H.C. Fehmann (Marburg, Gernany). We are indebted to Dr R Bouillon, Dr F Ostyn and Dr $F$ Penninckx for supplying specimens of human tissues, Dr $K$ Campbell for the antiserum against SERCA2b; $H$. van Duijnhoven, $M$. Kranenborg and $E$. Timmer for their contributions in raising monoclonal antibodies against NSPs, I. Pauli for excellent technical assistance; M. Willems and $G$. 
Vandereyken for culturing cell lines, and T. Ayoubi, F. Wuytack, I. wan Lint, J. Broers, and R. Derua for their helpful suggestions. This work was supported in part by the "National fonds voor Wetenschappelijk Onderzoek" (NFWO), the "Nederlandse Kankerbestrijding (project IKL9009), and the "Geconcerteerde Onderzoekacties" 1992-1996. This text presents results of the Belgian Programme on Interuniversity Poles of Attraction initiated by the Belgialn State, Prime Minister's Office, Science Policy Programming. H.J.K. wan de Velde is a Research Assistant of the National Fund for Scientific Research (Belgium).

\section{REFERENCES}

1. Rothman JE, Orci L. Molecular dissection of the secretory pathway. Nature 355: 409-415, 1992.

2. Gullmore $\mathbf{R}$. The protein translocation apparatus of the rough endoplasmic reticulum, its associated proteins, and the mechanism of translocation. Curr Opin Cell Biol 3: 580-584, 1991.

3. Rothman JE, Miller RL, Urbami LJ. Intercompartmental transport in the Golgi complex is a dissociative process: Facile transfer of membrane protein between two Golgi populations. I Cell Biol 99: 260-271, 1984.

4. Pelham HRB. Recycling of proteins between the endoplasmic reticulum and Golgi complex. Curr Opin Cell Biol 3: 585-591, 1991.

5. Van de Ven WJM, Van Duijhhoven JLP, Roebroek AIM. Structure and function of eukaryotic proprotein processing enzymes of the subtilisin family of serine proteases. Crit Rev Oncogen 4: $115-136,1993$.

6. Roebroek AJM, van de Velde HJK, Van Bokhoven A, Broers JLV, Ramaekers F.C.S., Van de Ven WJM. Cloning and expression of alternative transcripts of a novel neuroendocrine-specific gene and identification of its 135-kDa translational product. J Biol Chem 268: 13439-13447, 1993.

7. Kools PFJ, Roebroek AJM, van de Velde HJK, Marynen P, Bullerdiek J, Van de Ven WJM. Regional mapping of the human NSP gene to chromosome region $14 q 21-q 22$ by fluorescence in situ hybridization analysis. Cytogenet Cell Genet $66: 48-50,1994$

8. Lichte B, Veh RW, Meyer HE, Kilimann MW. Amphiphysin, a novel protein associated with symaptic vesicles. EMBO J $11: 2521-2530,1992$.

9. Roebroek AJM, Creemers JWM, Pauli IGL, Bogaert $T$, Van de Ven WIM. Generation of structural and functional diversity in furin-like proteins in Drosophila melanogaster by alternative splicing of the Dfurl gene. EMBO J 12: 1853-1870, 1993.

10. Tam JP, Zavala $\mathbb{F}$. Multiple antigen peptide: A novell approach to increase detection sensitivity of synthetic peptides in solid-phase immunoassays. J Immunol Meth 124: 53-61, 1989.

11. Van Duijnhoven JLP, Creemers JWM, Kranenborg MGC, Timmer EDJ, Groeneveld A, Van den Ouweland AWM, Roebroek AIM, Van de Ven WIM. Development and characterization of a parnel of monoclonal antibodies agatnst the novel subtilisin-like proprotein processing enzyme furin. Hybridoma 11: 71-86, 1992.

12. Van de Velde HJK, Roebroek AJM, van Leeuwen FW, Van de Ven WJM. Molecular analysis of expression in the rat brain of NSP-A, a novel neuroendocrine-specific protein of the endoplasmic reticulum. Mol Brain Res 23: 81-92, 1994.

13. Broers JLV, Mijhheere EP, Klein Rot M, Schaart G, Sijlmans A, Boerman OC, Ramakers FCS. Novel antigens characteristic of neuroendocrine malignancies. Cancer 67: 619-633, 1991.

14. Jorgensen $A$, Arnold $W$, Pepper D, Kahl $S$, Mandel $F$, Campbell $K$. A monocional antibody to the $\mathrm{Ca}^{2}+$ ATPase of cardiac sarcoplasmic reticulum cross-reacts with slow type I but not with fast type II canine skeletal muscle fibers: an immunocytochemical and immumochenical study. Cell Motil Cytoskel 9: 164-174, 1988.

15. Van Duijnhoven JLP, Ayoubi TAY, Timmer EDJ, Braks AAM, Roebroek AJM, Martens GJM. Van de Ven WJM. Development of a monoclonal atutibody against recombinant neuroendocrine 7B2 protein. FEBS Lett 255: 372-376, 1989

16. Leammli UK. Cleavage of structural proteins during assembly of the head of bacteriophage T4. Nature 227: $680-685,1970$.

17. Kamps MP, Sefton BM. Acid and base hydrolysis of phosphoproteins bound to immobilon facilitates analysis of phosphoamino acids in gel-fractionated proteins. Anal Biochem 176: 22 $27,1989$.

18. Verboomen H, Wuytack F. De Smedt H, Himpens B, Casteels $\mathrm{R}$. Functional difference between SERCA2a and SERCA2b Ca ${ }^{2+}$ pumps and their modulation by phospholamban. Biochen 1286 : $591-596, \$ 992$. 
19. Broers JLV, Klein Rot M, Oostendorp $T$, Bepler $G$, De Leij L, Carney DN, Vooijs GP, Ramaekers FCS. Spontaneous changes in intermediate flament protein expression patterns in lung cancer cell lines. J Cell Science 91:91-108, 1988.

20. Lee $C$, Chen LB. Dymamic behavior of endoplasmic reticulum in living cells. Cell 5: $37-46$, 1988.

21. Lytton J, Westlin $M$, Burk $S E$, Shull GE, MacLennan DH. Functional comparisons between isoforms of the sarcoplasmic or endoplasmic reticulum family of calcium pumps. I Biol Chem 267: 14483 14489, 1992 .

22. Wuytack F, Raeymaekers L, Verbist J, Jones LR, Casteels R. Smooth-muscle endoplasmic reticulum contains cardiac-like form of calsequestrin. Biochim Biophys Acta 899: 151-158, 1987.

23. Altschul SF, Gish W, Miller W, Myers EW, Lipman DI. Basic local alignment search tool. J Mol Biol 215: 403-410, 1990 .

24. Wieczorek DF, Hughes SR. Developmentally regulated cDNA expressed exclusively in neural tissue. Mol Brain Res 10: 33-41, 1991.

25. Martin-Gallardo A, McCombie WR, Gocayne JD, FitzGerald MG, Wallace S, Lee BMB, Lamerdin J, Trapp S, Kelley JM, Liu L-I, Dubnick M, Johnston-Dow LA, Kerlavage AR, De Jong $P$, Carrano $A$, Fields $C$, Venter JC. Automated DNA sequencing and analysis of 106 kilobases from human chromosome 19q13.3. Nature Genetics 1: 34-39, 1992.

26. Bell Gl, Takeda J. A molecular inventory of human pancreatic islets: sequence analysis of 1000 cDNA clones. Hum Mol Genet 2: 1793-1798, 1993.

27. Munro $S$, Pelham HRB. A C-tterminal signal prevents secretion of luminal ER proteins. Cell 48 : $899.907,1987$.

28. Pelham HRB. Control of protein exit from the endoplasmic reticulum. Annu Rev Cell Biol 5: 1-23, 1989.

29. Jackson $M R$, Nilsson $T$, Peterson PA. Identification of a consensus motif for retention of transmembrane proteins in the endoplasmic reticulum. EMBO J 10:3153-3162, 1990 .

30. Jackson MR, Nilsson T, Peterson PA. Retrieval of transmembrane proteins to the endoplasmic reticulum. J Cell Biol 121: 317-333, 1993.

31. Mitoma J, Ito A. The carboxy-terminal 10 amino acid residues of cytochrome b5 are necessary for its targeting to the endoplasmic reticulum. EMBO J $11: 4197-4203,1992$.

32. Broadwell RD, Cataldo AM. The neuronal endoplasmic reticulum: Its cytochemistry and contribution to the endomembrane system. I. Cell bodies and dendrites. I Histochem Cytochem 31: $1077-1088,1983$.

33. Broadwell RD, Cataldo AM. The neuronal endoplasmic reticulum: Its cytochemistry and contribution to the endomembrane system. II. Axons and terminals. J Comp Neurol 230: $231-248,1984$.

34. Alonso $\mathrm{G}$, Assenmacher I. The smooth endoplasmic reticulum in neurohypophysial axons of the rat: possible involvement in transport, storage and release of neurosecretory material. Cell Tissue
Res 199: 415-429, 1979 .

35. Hartter DE, Burton PR, Laverii LA. Distribution and calcium-sequestering ability of smooth endoptasmic reticulum in olfatory axon terminals of frog brain. Neurosei $23: 371-386,1987$. 


\title{
SUBCELLULAR LOCALIZATION AND SUPRAMOLECULAR ORGANIZATION OF NEUROENDOCRINE-SPECIFIC PROTEIN B (NSP-B) IN SMALL CELL LUNG CANCER
}

Nicole HM Senden, Helgi JK van de Velde, Jos LV Broers, Erika DJ Timmer, Helma JH Kuijpers, Anton JM Roebroek, Wim JM Van de Ven, Frans CS Ramaekers

Eur $J$ Cell Biol 65: $341-353,1994$

\begin{abstract}
We have recently isolated and characterized novel gene, that is expressed in a neuroendocrine (NE)-specific fashion, and was therefore designated neuroendocrinespecific protein (NSP)-gene. The NSP-gene encodes three transcripts of different size, with unique 5 '-sequences and completely overlapping 3 '-sequences. The resulting proteins have apparent molecular weights $(\mathrm{Mw})$ of $135 \mathrm{kDa}$ as determined for NSP-A and $23 \mathrm{kDa}$ as found for NSP-C. In the present study we focused on the biochemical characterization and subcellular localization of NSP-B, so far only found to be expressed in the NE lung cancer cell line NCI - H82, and its relation to NSP-A. Transfection studies with the NSP-B transcript in COS-1 cells, followed by immunoprecipitation, resulted in a set of proteins ranging in $\mathrm{Mw}$ from 35 to $45 \mathrm{kDa}$, identical to NSP-Bs detected by immunoblotting in NCI-H82. In this cell line a major NSP-B triplet in the $43-45 \mathrm{kDa}$ range and a $35 \mathrm{kDa}$ NSP-B were consistently detected. Only the $45 \mathrm{kDa}$ NSP-B was found to be phosphorylated. The observed pl values of the 43 $45 \mathrm{kDa}$ triplet ranged from 4.8 to 5.0 , while the $35 \mathrm{kDa}$ NSP-B has a more basic pl value of 5.7. Gel filtration studies show that NSP-A and NSP-B form supramolecular aggregates with a $\mathrm{MW}$ of over $500 \mathrm{kDa}$, present to a minor extent in the phosphate buffered saline (PBS) soluble cell fraction, but mainly occurring in the membranous pellet fraction from which they can be solubilized by Triton X-100. Complexes can either contain NSP-A or NSP.B separately, or comprise both these NSPs as concluded from immunoprecipitation and immunoaffinity chromatography studies. A subcellular distribution of NSP-A, similar to that of NSP-B in NCI-H82, has been seen in the NE lung cancer cell line SCLC-21H, in which NSP-A also occurs in oligomeric complexes. Immunofluorescence studies show an association of these NSP aggregates with the endoplasmic reticulum (ER), as concluded from double-labeling studies using an antibody to a $\mathrm{Ca}^{2+}$-ATPase SERCA2b. Immunofluorescence studies in COS-1 cells transfected with the NSP-B transcript showed that NSP-B also can interact with the ER as aggregates (reticulons) independently of NSP-A and NSP-C.
\end{abstract}




\section{$54 \quad$ Chapter 3}

\section{INTRODUCTION}

Recently, we have identified the NSP-gene, expressing three transcripts of different size and showing specificity for NE tissues and their neoplasms $[1,2]$. The NSP-gene has been mapped by fluorescence in situ hybridization analysis to human chromosome $14 \mathrm{q} 21-\mathrm{q} 22$ [3]. The three transcripts, with an estimated size of $3.4,2.3$ and $1.8 \mathrm{~kb}$, comprise identical 3 '-sequences but unique 5'-sequences. The $3.4 \mathrm{~kb}$ transcript encodes a protein with a calculated $\mathrm{Mw}$ of $85 \mathrm{kDa}$ (NSP-A, 776 amino acids). However, the observed $\mathrm{Mw}$ appeared to be $135 \mathrm{kDa}$, probably due to the presence of a large number of negatively charged residues in the amino-terminal part of NSP-A [1]. The $2.3 \mathrm{~kb}$ transcript encodes a protein with a calculated Mw of $39 \mathrm{kDa}$ (NSP-B, 356 amino acids) [1], while the smallest transcript of $1.8 \mathrm{~kb}$ encodes a $23 \mathrm{kDa}$ protein (NSP-C, 208 amino acids) [1]. To these NSPs both monoclonal and polyclonal antibodies have been raised. Of these, monoclonal antibodies (mabs) RNL-2 and RNL-3, were grouped during the Third Workshop on Lung Tumours and Differentiation Antigens as the cluster-10 lung cancer antibodies [2]. Using the different NSP antibodies in immunocytochemistry as well as in immunoblotting it was shown that these proteins exhibit a highly restricted tissue distribution and are mainly found in neural and NE cell types $[1,2,4]$. Mabs to NSP-A were strongly positive in human brain, peripheral nerve tissue and NE cells of for example pituitary gland and pancreas. Most of the human NE malignancies tested were found to be positive for NSP antisera. Of the different types of lung carcinomas only small cell lung carcinomas (SCLCs) and carcinoids were recognized, showing a granular cytoplasmic staining pattern, while non-SCLCs were mainly negative. Some non-SCLCs with NE features showed focal positivity. All cell lines derived from SCLC were shown to contain NSP-A and/or NSP-C, while NSP-B has so far been detected only in NCI-H82 [1,5].

This study addresses the biochemical characterization and subcellular localization of NSP-B, in relation to NSP-A. We show that at least four different NSP-B derived proteins, with Mw ranging from 35 to $45 \mathrm{kDa}$ exist in NCI-H82 and that these proteins can assemble at the ER as large aggregates, which we designate NSP-reticulons.

\section{MATERIALS AND METHODS}

\section{Cell cultures}

Cell lines used in this study included the SCLC cell lines NCI-H82, NCI-H524, SCLC-21H and for comparative reasons the non-SCLC cell lines NCI-H460, NCI-810 and $\mathrm{NCl}-\mathrm{H} 1155$, which have been shown to contain NE properties [6]. Sublines NCIH82-A and NCl-H524-A were obtained by selection of the adhering cells by removing the floating cells [7]. Establishment, characterization and growth patterns of these lung cancer cell lines have been described before [6-10]. Monkey kidney cell line COS-1, was used for transfection studies with CDNA coding for NSP-B. COS-1 cells were propagated in Iscove's modified minimal medium, supplemented with fetal calf serum $(10 \% \mathrm{v} / \mathrm{v})$ and antibiotics penicillin $(100 \mathrm{units} / \mathrm{ml})$ and streptomycin $(100 \mu \mathrm{g} / \mathrm{ml})$.

\section{Antibodies}

Antibodies used in this study are: mouse mabs RNL-2 and RNL-3 (IgGl subtype), 
which were raised against the SCLC cell line NCl-H82, recognizing epitopes in NSPA and NSP-B $[2,4]$; mouse mabs MON-160, MON-161 and MON-162 (IgG1 subtype), which were obtained by immunization with bacterially expressed, partially purified, fusion protein consisting of BGal sequences fused to NSP-A sequences (residues 6-776) using procedures as previously described [11]. These mabs are specific for NSP-A and were used as a 1:1:1 cocktail (MON 160-162) [1,2,12]; POL-1, a polyclonal rabbit antiserum, obtained by immunization with partially purified bacterial BGal-NSP-A hybrid protein, recognizing epitopes present in NSP-A and in NSP-B $[2,12]$; polyclonal rabbit antiserum to $\alpha$-tubulin, kindly provided by Dr M Borgers (Janssen Pharmaceutica, Beerse, Belgium); mab IID8 directed against a $\mathrm{Ca}^{2+}$-ATPase of the ER, kindly provided by Dr K Campbell (Howard Hughes, Medical Institute, Iowa City, Iowa, USA) [13]; polyclonal rabbit antiserum to synaptophysin, kindly provided by Dr J Askaa (DAKO A/S, Glostrup, Denmark).

\section{One- and two-dimensional gel electrophoresis and immunoblotting}

NCI-H82 and SCLC-21H cells were washed with PBS (NaCl $8 \mathrm{~g} / 1, \mathrm{KCl} 0.2 \mathrm{~g} / \mathrm{l}$, $\mathrm{Na}_{2} \mathrm{HPO}_{4} 1.15 \mathrm{~g} / \mathrm{l}$ and $\mathrm{KH}_{2} \mathrm{PO}_{4} 0.2 \mathrm{~g} / \mathrm{l}, \mathrm{pH} 7.4$ ) and lysed in a lysis buffer containing $62.5 \mathrm{mM}$ Tris-HCl (Merck, Darmstadt, FRG) pH 6.8, $12.5 \%$ glycerol (Janssen Chimica, Geel, Belgium), 2\% Nonidet P-40 (NP40; Fluka, Buchs, Switzerland), 1.25 $\mathrm{mM}$ EDTA (Merck) and as protease-inhibitors $2.5 \mathrm{mM}$ phenylmethylsulfonyl fluoride (PMSF; Merck), $12.5 \mu \mathrm{g} / \mathrm{ml}$ leupeptin (Sigma, St.Louis, USA) and $116 \mu \mathrm{g} / \mathrm{ml}$ aprotinin (Sigma). The cell lysates were dissolved by boiling during $5 \mathrm{~min}$ in SDS. sample buffer [14] containing 2.3\% sodiumdodecyl sulfate (SDS; Bio-Rad Laboratories, Richmond, CA, USA). One-dimensional SDS-polyacrylamide gel electrophoresis (SDS-PAGE) was performed in $10 \%$ polyacrylamide slab gels containing $0.1 \%$ SDS using a Mini Protean II Electrophoresis Cell (Bio-Rad Laboratories) [14]. Twodimensional gel electrophoresis was performed as described by O'Farrell [15]. Cell lysates were dissolved in SDS-sample buffer by boiling for $5 \mathrm{~min}$ and treated with $10 \%$ NP40. In the first dimension isoelectric focusing was performed in $4 \%$ polyacrylamide rod gels containing 4.5\% ampholines pH 3-10 (Bio-Rad Laboratories). For the second dimension the rod gels were applied directly onto the stacking gel of $10 \%$ SDS-polyacrylamide gells. After electrophoretic separation, the proteins were either stained with PAGE-Blue 83 (BDH Chemicals Ltd., Poole, UK) to compare the amounts of protein loaded onto the gel, or subjected to immunoblotting using a Mini Trans-Blot Electrophoretic Transfer Cell (Bio-Rad Laboratories). The separated polypeptides were transferred to a nitrocellulose membrane (Filter BA 85 , Schleicher and Schüll, Dassel, FRG) by blotting for $1 \mathrm{~h}$ at $100 \mathrm{~V}$ in a cold $\left(4^{\circ} \mathrm{C}\right)$ buffer containing $25 \mathrm{mM}$ Tris- $\mathrm{HCl}, 192 \mathrm{mM}$ glycine (Merck) and 20\% methanol (Merck). For the immunochemical detection of NSPs in the blots the alkaline phosphatase reaction or the ECL chemiluminescence method (Amersham International, Buckinghamshire, UK) was used. First, the nitrocellulose sheets were incubated for $1 \mathrm{~h}$ at room temperature with $3 \%$ bovine serum albumin (BSA; Sigma) in PBS. Then blots were incubated overnight at room temperature with primary antisera. All antisera were diluted in 5\% non fat dry milk (Biorad Laboratories) and $0.1 \%$ Tween 20 (Janssen Chimica) in PBS, which was also used for all washing steps. Thereafter, blots were washed three times for $10 \mathrm{~min}$. For detection with the alkaline phosphatase reaction, blots were incubated for $1 \mathrm{~h}$ with alkaline phosphatase conjugated rabbit anti mouse Ig 
(DAKO A/S, Glostrup, Denmark) in a 1:750 dilution. Thereafter, the blots were washed again three times. After a final washing step with a buffer containing $0.1 \mathrm{M}$ Tris-HCl pH 9.5, 0.1 M NaCl (Merck), $5 \mathrm{mM} \mathrm{MgCl}_{2}$, detection of alkaline phosphatase was performed with $0.33 \mathrm{mg} / \mathrm{ml} 5$-bromo-4 chloro-3 indolyl phosphate (BCIP, Sigma) and $0.67 \mathrm{mg} / \mathrm{ml}$ 4-nitro-blue tetrazolium chloride (NBT, Sigma) in this buffer. The reaction was stopped by adding $20 \mathrm{mM}$ EDTA in PBS. For detection with the chemiluminescence method nitrocellulose sheets were incubated for $1 \mathrm{~h}$ with horseradish peroxidase conjugated to swine anti-rabbit Ig (Dako A/S) or to rabbit antimouse $\lg$ (Dako $\mathrm{A} / \mathrm{S}$ ), in a dilution of $1: 1000$. After three additional washing steps, followed by a wash in PBS containing $0.1 \%$ Tween 20 , blots were treated for $1 \mathrm{~min}$ with the chemiluminescence fluid ECL. Finally a Fuji medical X-ray film RX (Fuji Photo Film Co. Ltd, Japan) was exposed to the nitrocellulose sheets for 15 sec up to 5 $\min$.

\section{Epitope mapping of monoclonal antibodies RNL-2 and RNL-3}

In order to map the epitopes recognized by RNL-2 and RNL-3, the $1.8 \mathrm{~kb} E c o$ RI CDNA insert of plasmid pAB15 encoding NSP-B, as well as subfragments of pAB15 [1] were cloned into the bacterial expression vector pATH11. [16]. In this expression vector the NSP coding region was cloned in-frame to the 3 '-end of a portion of the trpE gene of E.coli. Cloning of the complete $1.8 \mathrm{~kb}$ EcoRI cDNA into pATH11 resulted in pAB29, whereas cloning of two 5 "-end fragments, a $340 \mathrm{kbp} \mathrm{EcoRI-SacI}$ fragment and a $620 \mathrm{kbp} E c o$ RI-Xhol fragment, resulted in pAB54 and pAB61, respectively. The inserts of pAB54 and pAB61 encode only N-terminal parts of the NSP-B protein up to amino acid residues 46 and 138, respectively (Fig. la). It should be noted that the plasmids of the NSP coding sequences are linked to trpE coding sequences via intervening sequences consisting of sequences $5^{\prime}$-upstream of the authentic translation initiation site of the NSP-B protein. Normally, these 5'-upstream sequences are not translated into NSP-B. Expression of the hybrid trpE-NSPs was induced as described [16]. The hybrid trpE-NSPs were analyzed for immunoreactivity with RNL-2 and RNL-3 by immunoblot analysis.

\section{Cell fractionation (for overview see figure $5 \mathrm{~A}$ )}

Subconfluent NCI-H82 and SCLC-21H cells were harvested by centrifugation at $200 \mathrm{~g}$ for 5 min, washed once in cold $\left(4^{\circ} \mathrm{C}\right) \mathrm{PBS}$, and resuspended at $4^{\circ} \mathrm{C}$ in PBS pH 7.4 containing $0.4 \mathrm{mM}$ PMSF, $1 \mathrm{mM}$ ethylene glycol-bis( $(B$-aminoethyl ether)N,N,N'N'tetraacetic acid (EGTA; Merck and $1 \mathrm{mM}$ EDTA. The cells were then homogenized by 10 strokes using a potter $S$ homogenizer (Braun, Melsingen, FRG) using a tightfitting glass pestle. The homogenate was separated into a pellet $\mathrm{P} 1$ and a supernatant S1 by low speed centrifugation at $4400 \mathrm{~g}$ for $10 \mathrm{~min}$ at $4^{\circ} \mathrm{C}$. Pellet P1 was extracted with $1 \%$ Triton $X-100$ (Janssen Chimica) in PBS for $1 \mathrm{~h}$, after washing in PBS, and recentrifuged at $4400 \mathrm{~g}$ for $10 \mathrm{~min}$ resulting in pellet $\mathrm{P} 2$ and supernatant $\mathrm{S} 2$. The supernatant $S 1$, obtained after the first centrifugation step and the supernatant $S 2$, obtained after Triton X-100 extraction, were both centrifuged at $100,000 \mathrm{~g}$ for $1 \mathrm{~h}$ to obtain soluble protein fractions $S 3$ and $S 4$, respectively. The pellet $\mathrm{P} 4$ resulting from $100,000 \mathrm{~g}$ centrifugation of S1 was further extracted with $1 \%$ Triton X-100 for $1 \mathrm{~h}$ and recentrifuged at $100,000 \mathrm{~g}$ resulting in pellet P5 and supernatant S5. From the pellet and supernatant fractions aliquots were taken, dissolved by boiling for $5 \mathrm{~min}$ in 
SDS-sample buffer and assayed for NSP-A and NSP-B by immunoblotting.

\section{Indirect immunofluorescence microscopy}

Floating NCI-H82 cells were attached to coverslips coated with $0.1 \mathrm{mg}$ poly-L-lysine (Sigma) and fixed as described below. Preparations of the non-SCLC cell line NCIH1155 and NCI-H810 were made by cytocentrifugation. NCI-H82-A, NCI-H524-A, NCI-H460 which grow as adherent cultures, were detached with $0.125 \%$ trypsin (Difco Laboratories, Detroit, USA), 0.02\% EDTA and $0.02 \%$ glucose (Merck) in PBS $\mathrm{pH} 7.4$ and thereafter allowed to grow on glass cover slips for $1-2$ days. COS-1 cells transfected with the NSP-B transcript, were grown for $48 \mathrm{~h}$ on poly-L-lysine coated glass slides. All cells were either fixed by dipping in methanol for $5 \sec \left(-20^{\circ} \mathrm{C}\right)$, followed by acetone (Merck) 3 times for $5 \sec \left(4^{\circ} \mathrm{C}\right)$ or fixed in $4 \%$ paraformaldehyde (Merck) in PBS for $10 \mathrm{~min}$ and then gently permeabilized for 2 min with PBS containing $0.02 \%$ saponin (Merck). Subsequently, the cells were incubated for $1 \mathrm{~h}$ with the primary antibody diluted in PBS. After repeated washing in PBS the secondary antibody was applied to the cells. Secondary antibodies included fluorescein isothiocyanate (FITC)-conjugated rabbit anti-mouse $\operatorname{Ig}(1: 100 ; \mathrm{DAKO} \mathrm{A} / \mathrm{S})$, FITCconjugated goat anti-mouse IgG (1:25; Nordic, Tilburg, The Netherlands) and Texas Red-conjugated goat anti-rabbit Ig (1:80; Southern Biotechnology Association, Inc. (SBA), Birmingham, USA). In the double-label inmunofluorescence technique a mixture of two primary antibodies was applied in the first step and after washing with PBS, a mixture of FITC-conjugated goat anti-mouse IgG and Texas Red-conjugated goat anti-rabbit $\mathrm{Ig}$ was added. After incubation for $1 \mathrm{~h}$ the cells were washed again in PBS and mounted in $90 \%$ glycerol in $0.2 \mathrm{M}$ Tris- $\mathrm{HCl} \mathrm{pH} 8.0$ with addition of $2 \% 1,4$ diazobicyclo-[2,2,2]-octane (DABCO; Merck) and $0.02 \%$ sodium-azide (Merck). As negative controls the primary antibody was replaced by PBS or by a non-relevant antiserum. Slides were viewed with a Zeiss Axiophot microscope (Zeiss, Oberkochen, Germany). For confocal scanning laser microscopy cells were mounted in Vectashield (Vector Laboratories, Burlingame, USA), and examined with a Bio-Rad MRC-600 confocal scanning laser microscope (CSLM; Bio-Rad Laboratories) equipped with a Crypton/Argon mixed gas laser (Ion Laser Technology, Salt Lake City, Utah, USA) with two separate wavelengths for the excitation of FITC $(488 \mathrm{~nm})$ and Texas Red $(568 \mathrm{~nm})$. Photographs were taken directly from the monitor with a Nikon camera using a 400 ASA Tri-X pan or Ektachrome film (Kodak).

\section{Expression of NSP-B cDNA in COS-1 cells}

Cloning and analysis of NSP cDNAs corresponding to NSP mRNAs has been described previously [1]. For expression in COS-1 cells of cDNA encoding NSP-B, the complete coding region of corresponding CDNA was cloned into the Xhol site of pSVL, and the resulting clones named PSVL-NSP-B. In the PSVL constructs, expression of the NSP cDNAs is under control of the SV40 late promoter. Twentyfour hours upon seeding, the semi-confluent cells were transfected with $10 \mu \mathrm{g}$ of DNA in $2 \mathrm{ml}$ of Iscove's modified minimal medium, supplemented with $200 \mu \mathrm{g} / \mathrm{ml} \mathrm{DEAE}$ dextran. In the transfection procedure, a chloroquine shock was included [17]. Thirtysix hours after transfection, cells were labeled with $\left[{ }^{35}\right.$ S $]$ methionine, and immunoprecipitation analysis of NSP-encoded proteins was performed as described previously [1]. For immunofluorescence analysis cells were maintained in the medium 
described above, and 48 h after transfection fixed and immunostained as described above.

\section{Gel filtration}

$0.5 \mathrm{M}$ Biogel Agarose beads (Bio-Rad Laboratories) with an exclusion limit of 500 , 000 daltons were used to determine the Mw of the native NSPs present in the PBS soluble $100,000 \mathrm{~g}$ supernatant $\$ 4$ and in the Triton $\mathrm{X}-100$ soluble $100,000 \mathrm{~g}$ supernatant S3 of NCI-H82 and SCLC-21H. The column was equilibrated either with PBS or with $1 \%$ Triton X-100 in PBS for 3 volumes with a flow rate of $1 \mathrm{ml} / \mathrm{min}$. Eye-lens crystallins from calf [18], Blue Dextran 2000 (Pharmacia, Uppsala, Sweden) and Bromophenol Blue (Sigma) were used to calibrate the column. Extracts were applied at a flow rate of $1 \mathrm{ml} / \mathrm{min}$, while $4 \mathrm{ml}$ fractions were collected. Aliquots were taken and assayed either in an enzyme-linked immunosorbent assay (ELISA) or by immunoblotting as described. For the ELISA 96-well polystyrene flat bottom E.I.A/ R.I.A microtiter plates (Costar, Cambridge, USA) were coated with $200 \mu$ l poly-L-lysine $(0.1 \mathrm{mg} / \mathrm{ml})$ for $45 \mathrm{~min}$ and subsequently coated with $100 \mu \mathrm{l}$ of each gel filtration fraction by centrifugation at $200 \mathrm{~g}$ for $10 \mathrm{~min}$. Each fraction was assayed in triplicate. All antisera were diluted in $1 \%$ normal goat serum (NGS) while all washing steps were carried out in $0.5 \%$ Tween 20 in PBS. After preincubation with $1 \%$ NGS in PBS for $15 \mathrm{~min}$ and three washing steps (each $10 \mathrm{~min}$ ), primary antibody incubations with Mabs RNL-2 or RNL-3 were performed at room temperature for $1 \mathrm{~h}$. After three additional washing steps for $10 \mathrm{~min}$, horse-radish peroxidase conjugated rabbit antimouse $\operatorname{IgG}($ Dako A/S) was applied for $1 \mathrm{~h}$ at room temperature in a 1:500 dilution. The microtiter plates were washed extensively (five washing steps of $10 \mathrm{~min}$ each) followed by detection of peroxidase by adding $100 \mu$ l of a fresh substrate solution of $0.04 \%$ ortho-phenylenediamine dihydrochloride (OPD; Sigma) and $0.006 \%$ hydrogen peroxide (Merck) in $0.1 \mathrm{M}$ citrate/phosphate buffer pH 6 to each well. The reaction was allowed to proceed in the dark for $30 \mathrm{~min}$ and was stopped by adding $100 \mu \mathrm{l} 1 \mathrm{M}$ $\mathrm{H}_{2} \mathrm{SO}_{4}$ to each well. The collor intensity of the wells was measured at $492 \mathrm{~nm}$ in a microplate reader model 450 (Bio-Rad Laboratories).

\section{Immunoaffinity chromatography}

About 5-10 mg RNL-2 $\mathrm{IgG}$ or MON $160-162 \mathrm{IgG}$, purified from mouse ascites by Protein G (Pharmacia) chromatography, was immobilized to $1 \mathrm{ml}$ cyanogen bromide (CNBr)-activated Sepharose $4 \mathrm{~B}$ (Pharmacia) according to the manifacturers instructions. In case of affinity chromatography of Triton X-100 extracted NSPs, the column was first equilibrated with $1 \%$ Triton $X-100$ in PBS, pH 7.4 at a flow rate of $0,08 \mathrm{ml} / \mathrm{min}$. Thereafter, the $S 3$ extracts (see figure $5 \mathrm{~A}$ ) or the $100,000 \mathrm{~g}$ supernatants of $1 \%$ Triton X-100 extracted total cell homogenates of NCI-H82 and SCLC-21H were allowed to bind to the column overnight at a flow rate of $0,05 \mathrm{ml} / \mathrm{min}$, and washed subsequently with $10 \mathrm{vol} 1 \%$ Triton X-100 in PBS and with 5 vol PBS. In case of affinity chromatography of PBS soluble NSPs all steps were performed without Triton $\mathrm{X}-100$. The S4 extracts of NCI-H82 were allowed to bind to the column. Bound material was eluted with $20 \mathrm{ml} 0.1 \mathrm{M}$ glycine/HCl (Merck) pH 2.5 at a flow rate of $0.2 \mathrm{ml} / \mathrm{min}$ and immediately neutralized with $1 \mathrm{M}$ Tris $-\mathrm{HCl} \mathrm{pH} 8.0$. One $\mathrm{ml}$ fractions were collected and aliquots were subjected to gel electrophoresis. After electrophoretic separation protein bands were either detected with silver stain (Bio-Rad Lab\&2ora- 
tories) or subjected to blotting. The nitrocellulose sheets were either stained for total protein with the colloidal gold reagent (Aurodye forte; Janssen Life Sciences, Beerse/Belgium) or assayed with NSP antibodies.

\section{Immunoprecipitation analyses}

NCI-H82 and SCLC-21H cell pellets were homogenized in PBS $\left(4^{\circ} \mathrm{C}\right)$ containing 0.4 mM PMSF, 1 mM EDTA, $1 \mathrm{mM}$ EGTA, $12.5 \mu \mathrm{g} / \mathrm{ml}$ leupeptide and $116 \mu \mathrm{g} / \mathrm{ml}$ aprotinine using a potter $S$ homogenizer (10 strokes: tight fitting pestle) and centrifuged at $100,000 \mathrm{~g}$ for $1 \mathrm{hr}$ at $4^{\circ} \mathrm{C}$. Using these supernatant fractions, immunocomplexes of the NSPS with either RNL-2 or RNL-3, or with a mixture of MON 160-162 were formed by incubating overnight at $4^{\circ} \mathrm{C}$ in a immunoprecipitation buffer containing $20 \mathrm{mM}$ Tris- $\mathrm{HCl} \mathrm{pH} 8.0,1 \mathrm{mM}$ PMSF, $12.5 \mu \mathrm{g} / \mathrm{ml}$ leupeptide, $116 \mu \mathrm{g} / \mathrm{ml}$ aprotinine and 140 $m \mathrm{M} \mathrm{NaCl}$, followed by incubation with two $\mu \mathrm{l}$ rabbit anti-mouse immunoglobulins for $2 \mathrm{~h}$. Thereafter, $100 \mu \mathrm{l}$ Protein A - Sepharose CL-4B (Pharmacia) $(30 \mathrm{mg} / \mathrm{ml}$ ) were added for $3 \mathrm{~h}$. The immunocomplexes formed were washed 5 times by centrifugation at $13,000 \mathrm{~g}$ for $2 \mathrm{~min}$. with immunoprecipitation buffer and subsequently diluted in SDS-sample buffer, boiled for $5 \mathrm{~min}$ and analyzed gel electrophoretically followed by immunoblotting.

\section{RESULTS}

\section{Epitope mapping of monoclonal antibodies RNL-2 and RNL-3}

In order to map the epitopes recognized by the mabs RNL-2 and RNL-3 to the NSP sequence, different CDNA fragments derived from NSP-B transcripts were cloned into a bacterial expression vector (clones pAB29, pAB54 and pAB61 as schematically represented in Fig. 1). After expression, the different hybrid trpE-NSP-B proteins were subjected to electrophoretic separation. Staining of these gels with Coomassie Brilliant Blue clearly showed the bands of the different hybrid proteins (arrowheads in Fig. $2 A$ ). Immunoblotting of these hybrid trpE-NSP proteins with RNL-2 and RNL-3 resulted in an immunoreactivity with the hybrid proteins derived from pAB29 and pAB61 at the appropriate $M w$ level, but not with the protein derived from pAB54 or with trpE alone (Figs. $1 \mathrm{~B}$ and 1C). This observation indicates that the epitopes recognized by these two mabs are located in the region between amino acids 47 to 138 of NSP-B, which corresponds with the region between amino acids 467 to 558 of NSPA.

\section{Immunoprecipitation of NSP-B expressed in COS-1 cells}

To characterize the products of the $2.3 \mathrm{~kb}$ NSP-transcript, COS-1 cells were transfected with pSVL-NSP-B CDNA, and immunoprecipitation analysis was performed with RNL-2 and RNL-3. From a $\left[{ }^{35}\right.$ S]-methionine labeled lysate of transfected COS-1 cells, a protein with an approximate $\mathrm{Mw}$ of $45 \mathrm{kDa}$ and a $35 \mathrm{kDa}$ protein were immunoprecipitated using a mixture of RNL-2 and RNL-3 (Fig. 2, lane 1). These labeled proteins migrate in the same positions as the immunoreactive products as detected in NCI-H82 cells with these two antibodies in earlier studies $[1,2,4]$. In immunoprecipitation analysis of non-transfected COS-1 cells the $45 \mathrm{kDa}$ and $35 \mathrm{kDa}$ proteins were not present (Fig. 2, lane 2). 


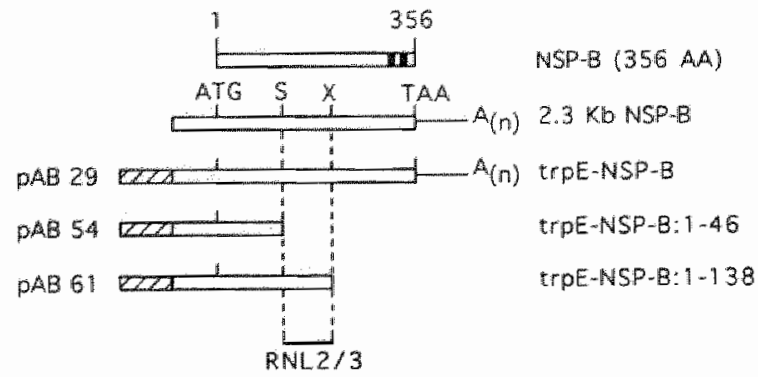

B

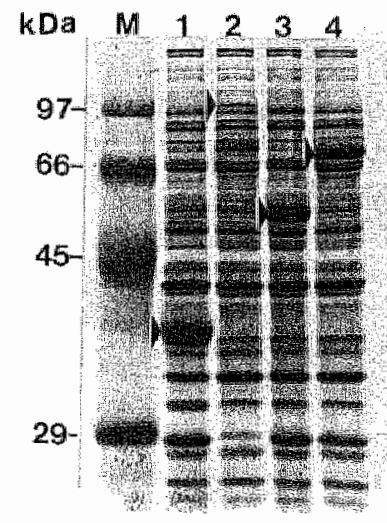

C

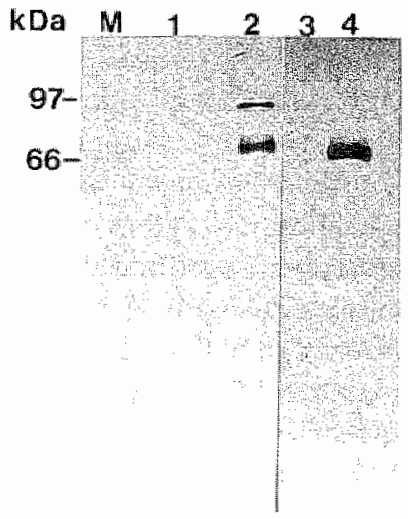

D

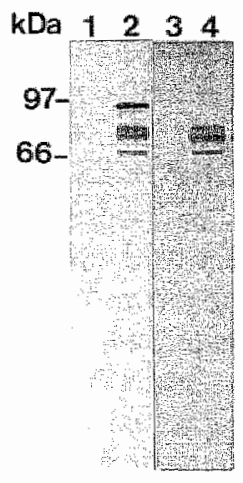

Figure 1. Epitope mapping of RNL-2 and RNL-3. (A) Schematic representation of DNA constructs encoding various hybrid proteins containing sequences derived from trpE and NSP-B CDNA. At the top of the figure the deduced domain structure of NSP-B is shown. Hydrophobic regions in the carboxy-terminal part of the protein are indicated as black boxes. The open reading frame of the 2.3 $\mathrm{kl}$ NSP-B mRNA (encoding 356 amino acids) with the relative position of relewant restriction endonuclease cleavage sites is indicated as an open box. DNA constructs pAB 29 encoding trpE-NSP$B_{n}$ pABS4 encoding trpE-NSP-B1-46 and pAB 61 encoding trpE-NSP-B1-138 are schematically represented. The regions encoding $\operatorname{trp} \mathrm{E}$ sequences, are indicated as shaded boxes and the NSPencoding regions as open boxes. The epitope region of RNL-2 and RNL-3 between amino acids 47 and 138 of NSP-B is indicated. (B) Analysis of hybrid trpE-NSP-B proteins by gel ellectrophoretic separation and staining with Coomassie Brilliant Blue. Total bacterial lysates containing hybrid protein trpE (lane 1), trpE-NSP-B (lane 2), trpE-NSP-B1-46 (lane 3) and trpE-NSP-B1-138 (lane 4). The locations of fusion proteins are indicated by arrow heads. (C) Immunoblot analysis of the bacterially expressed hybrid trpE-NSP proteins. The same bacterial lysates as described under (b) were sizefractionated by SDS-PAGE, transferred to nitrocellulose and stained with RNL-2. Lane 1) trpE; lane 2) trpE-NSP-B; lane 3) trpE-NSP-B1-46; tane 4) trpE-NSP-B-I-138. Note reactivity of RNL-2 with construct $\mathrm{pAB} 29$ (lane 2) and $\mathrm{pAB} 6 \mathrm{I}$ (lane 4) and not with $\mathrm{PAB} 54$ (lane 3). (D) Immunoblot analysis of bacterially expressed hybrid trpE proteins with RNL-3. Lane 1) trpE; lane 2) trpE-NSP-B; lane 3) trpE-NSP-BI-46; lane 4) trpE-NSP-BL-138. Identical reactivity of RNL-3 as with RNL-2 was. observed in the same constructs (compare with $\mathrm{c}$. Lanes $\mathrm{M}$, molecular weight markers. 


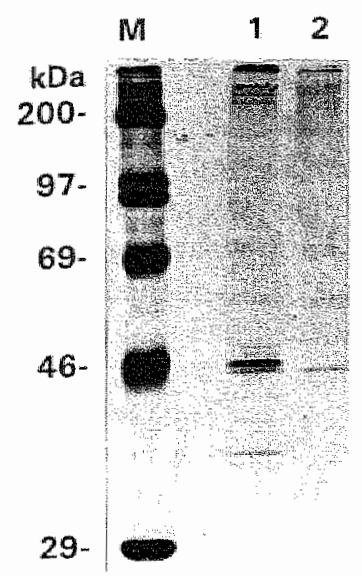

\begin{abstract}
Figure 2. Immunoprecipitation with a mixture of monoclonal antibodies RNL-2 and RNL-3 of $\left.{ }^{35} \mathrm{~S}\right]$-methionine-labelled lysates of COS-1 cells transfected with NSP-B cDNA. Lane I) COS-1 cells transfected with pSVL-NSP-B; lane 2) non-transfected COS-1 cells. Radioactive molecular weight markers are indicated in lane $M$. Note the 45 and $35 \mathrm{kDa}$ protein bands of NSP-B in lane 1 .
\end{abstract}

\title{
Detection of NSP-A and NSP-B with the different anti-NSP antibodies in small cell lung cancer cell lines NCI-H82 and SCLC-21H by immunoblot analysis
}

Immunoblot analysis of lysates of NCI-H82 with antibodies RNL-2 and RNL-3 revealed a strong reaction of proteins ranging in $\mathrm{Mw}$ from 35 to $45 \mathrm{kDa}$ and an additional band in the $135 \mathrm{kDa}$ region, i.e. NSP-A (Fig. 3, lanes 1 and 3). The band in the $45 \mathrm{kDa}$ region does in fact consist of a triplet of NSP-B proteins ranging in $\mathrm{MW}$ between 43 and $45 \mathrm{kDa}$. Of this triplet the higher $44-45 \mathrm{kDa}$ doublet appeared to be phosphorylated (data not shown). A mixture of mabs MON 160-162 revealed only the $135 \mathrm{kDa}$ protein (Fig. 3, lane 4). With the polyclonal rabbit antiserum POL-1 the triplet of $43-45 \mathrm{kDa}$ proteins and the $135 \mathrm{kDa}$ protein could be detected, but not the 35 $\mathrm{kDa}$ NSP-B (Fig. 3, lane 6). The $135 \mathrm{kDa}$ protein was also found to be expressed in SCLC-21H and could be recognized either with RNL-2 and RNL-3 (Fig. 3, lane 2), with a cocktail of mabs MON 160-162 (Fig. 3, lane 5) or with the polyclonal rabbit antiserum POL-1 (Fig. 3, lane 7).

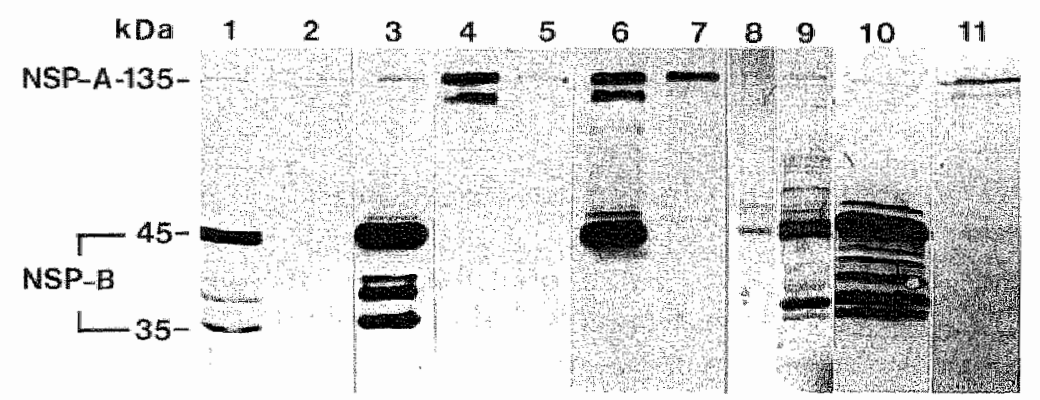

Figure 3. Detection of NSP-A and NSP-B in total cell lysates of NCl-H82 (lanes $1,3,4,6$ ) and SCLC 21-H (lanes 2,5,7) after gel electrophoretic separation and immunoblotting. Lanes 1 and 2) immunoblot incubated with a mixture of RNL-2 and RNL-3 and detected with alkaline phosphatase Iane $^{2}$ ) immunoblot incubated with a mixture of RNL-2 and RNL-3, visualized with the chemiluminiscence method; lanes 4 and 5) immunoblot incubated with the MON-160-162 cocktail, visualized with the chemiluminescence method; lanes 6 and 7) immunoblot incubated with POL-1, vilsualized with the chemiluminescence method. In lanes 8 to 11 the RNL-2 immunoaffinity eluate of the Triton X=100 soluble fraction $\mathrm{S3}$ (see Fig. 5a) of NCI-H82 cells is loaded. Lane 8) silver stained NSPs eluted from the RNL-2 affinity column; lane 9) colloidal gold staining of NSPs eluted from the RNL-2 affinity column; lane 10) RNL-3 immunostaining of NSPS eluted from the RNL-2 affinity column; lane 11) MON $160-162$ immunostaining of NSPS eluted from the RNL-2 affinity column. 
NSP-A and NSP-B can be immuno-purified from the PBS soluble fraction as well as from Triton $\mathrm{X}-100$ soluble extracts of $\mathrm{NCI}-\mathrm{H} 82$ cells using the RNL-2 affinity-column. However, initial standard protein quantitation of the proteins eluted from this column at $\mathrm{pH} 2.5$ by the Bio-Rad protein assay or by the bicinchoninic acid method [19] revealed no significant protein amounts. Also, gel electrophoretic separation of the elluted proteins and subsequent staining of the gel with Coomassie Brilliant Blue did not result in any staining reaction. Moreover, ink staining of the eluted proteins, blotted to nitrocellulose, showed only a weak reaction. However, silver staining of the gell (Fig. 3, lane 8) and staining of the blot with colloidal gold (Fig. 3, lane 9) did show the presence of NSPs. Immunoblotting showed indeed large amounts of NSP-A and NSP-B were present in the eluted fractions (Fig. 3, lanes 10 and 11). In such immunoblots, containing relatively high amounts of NSP preparations, also minor protein bands between $35 \mathrm{kDa}$ and $43 \mathrm{kDa}$ became apparent.

Two-dimensional immunoblotting experiments showed that the protein triplet in the 43 $45 \mathrm{kDa}$ region exhibit an isoelectric $\mathrm{pH}$ between 4.8 and 5.0 (Fig. 4). Careful examination of the $43-45 \mathrm{kDa}$ protein triplet revealed that the higher protein doublet has an isoelectric $\mathrm{pH}$ slightly more acidic than the $43 \mathrm{kDa}$ protein. This is in line with the finding that the $44-45 \mathrm{kDa}$ NSP-B doublet is phosphorylated and that the $43 \mathrm{kDa}$ NSP-B is not. The $35 \mathrm{kDa}$ protein exhibits a more basic pl of approximately 5.7 , while some of the minor protein bands, already detected in the one-dimensional immunoblot (Fig. 3, lane 10), showed a pl in between 5.0 and 5.5 .

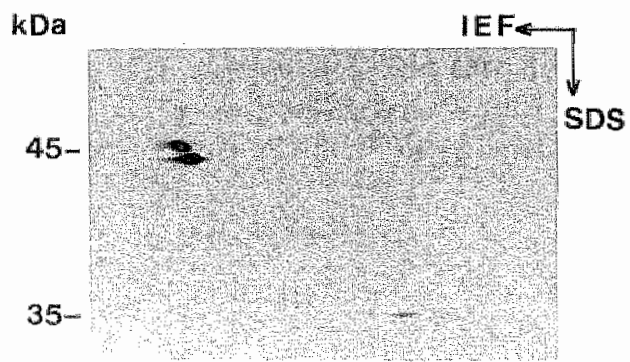

Figure 4. Two-dimensional immunoblotting of NCI.H82 cell lysates incubated with RNL-3. A strong immunostaining of the $45 \mathrm{kDa}$ protein was observed at a pl of 4.8-5.0, while a weaker spot was seen for the $35 \mathrm{kDa}$ protein at $\mathrm{pl}=5.7$.

\section{Subcellular localization of NSPs in lung cancer cell lines}

Cell fractionation (Fig. 5). Differential centrifugation experiments performed with NCI-H82 and SCLC-21H cells were used to define the subcellular localization of NSPA and NSP-B. It became apparent that after homogenization of the NCI-H82 cells, NSP-A and NSP-B were retained in the low speed (4400g) pellet fraction Pl (Figs. 5b and $5 \mathrm{c}$ ), but also sedimented together with microsomal membranes during high speed $(100,000 \mathrm{~g})$ centrifugation of the PBS soluble fraction S1, resulting in pellet P4 (Fig. 5b). Extraction of the low speed pellet P1 and the microsomal pellet P4 with different detergents (data not shown), revealed that Triton X-100 could efficiently solubilize both NSP-A and NSP-B from these membrane fractions resulting in S2, S3 and S5 (Figs. 5b and 5c). The experiments also revealed a codistribution of NSP-A and NSP$B$ in these subcellular components of NCI-H82. An enrichment of NSP-A after a Triton X-100 extraction of the low speed pellet P1, could also been found in the cell 
line SCLC-21H (Fig. 5d). In this cell line NSP-A alone behaved very similar to the NSP-A and NSP-B in NCI-H82 during the different extraction steps.

A
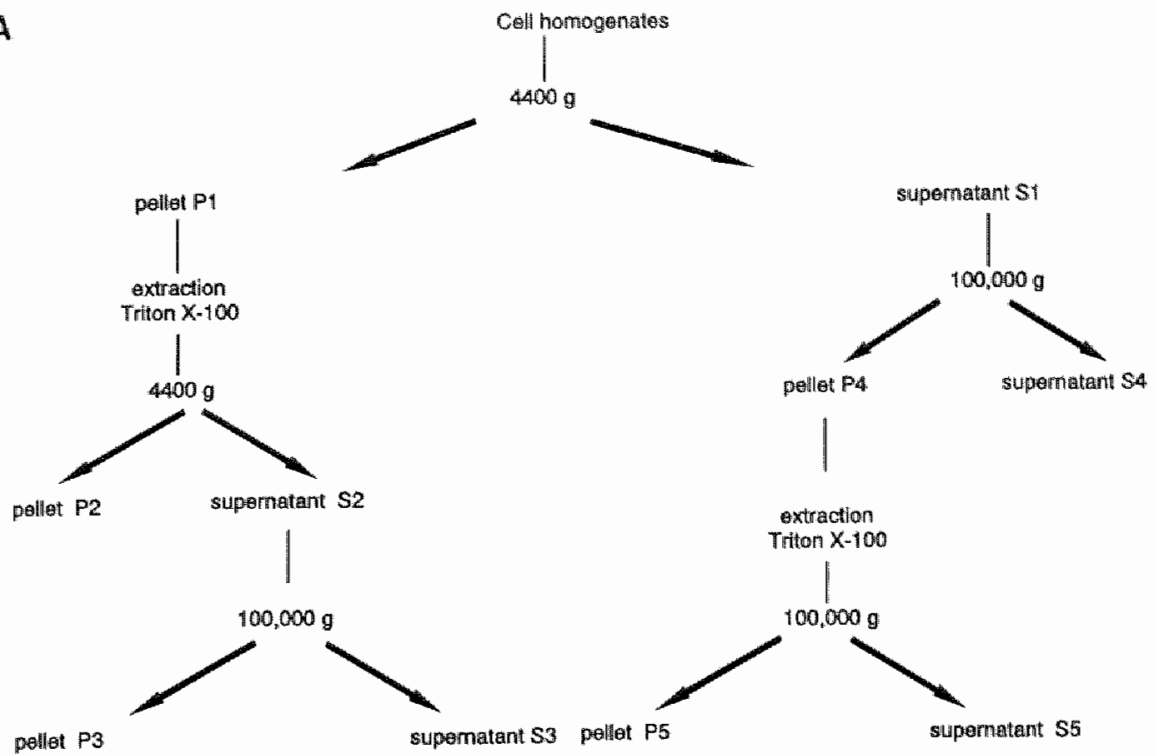

B T P P NSP-ANSP $\mathrm{B}_{2}=--$

c

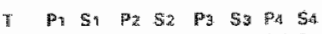
D $p_{1}$ is $p_{3}$ 解 $p_{4}$ s.
Figure 5. Cel fractionation study of cell lines NCI-H82 and SCLC-21H. (a) Schematic overview of the procedure used. (b) Immunoblotting analysis of the NSPS of NCI-H82 present in the different fractions as indicated in (a). The blot was first incubated with antibody RNL-2, followed by incubation with a mixture of MON 160-162. NSPs were detected with alkaline phosphatase. (c) Immunoblotting analysis of the NSPS of $\mathrm{NCl}-\mathrm{H} 82$ present in the different fractions as inclicated in (a). The mixture of antibodies MON 160-162 were used to detect NSPS visualised with the chemiluminiscence method. (d) Immunoblotting analysis of NSP's of SCLC $21-\mathrm{H}$ present in the different fractions as indicated in (a). The mixture of MON 160-162 were used to detect NSPs visualised with the chemiluminiscence method. Prestained molecular weight markers are indicated in lanes $M$. 
Immunofluorescence localization. Immunostaining of $\mathrm{NCI}-\mathrm{H} 82, \mathrm{NCI}-\mathrm{H} 82-\mathrm{A}, \mathrm{NCl}-$ H524-A, NCI-H460, NCI-H810 and NCI-HI155 cells with RNL-2 and RNL-3, resulted in the delection of a fibrogranular network, spanning the whole cytoplasm with a perinuclear concentration (Figs. $6 \mathrm{~A}$ and $6 \mathrm{C}$ ). This typical staining pattern of NSPs, is also observed with the rabbit polyclonal antiserum POL-1 (Fig. 6B). When the distribution of these NSPs is compared to that of the Ca ${ }^{2+}$-ATPase SERCA2b, present in the ER and detected by antibody IID8 similar patterns are found (Fig. 6D).
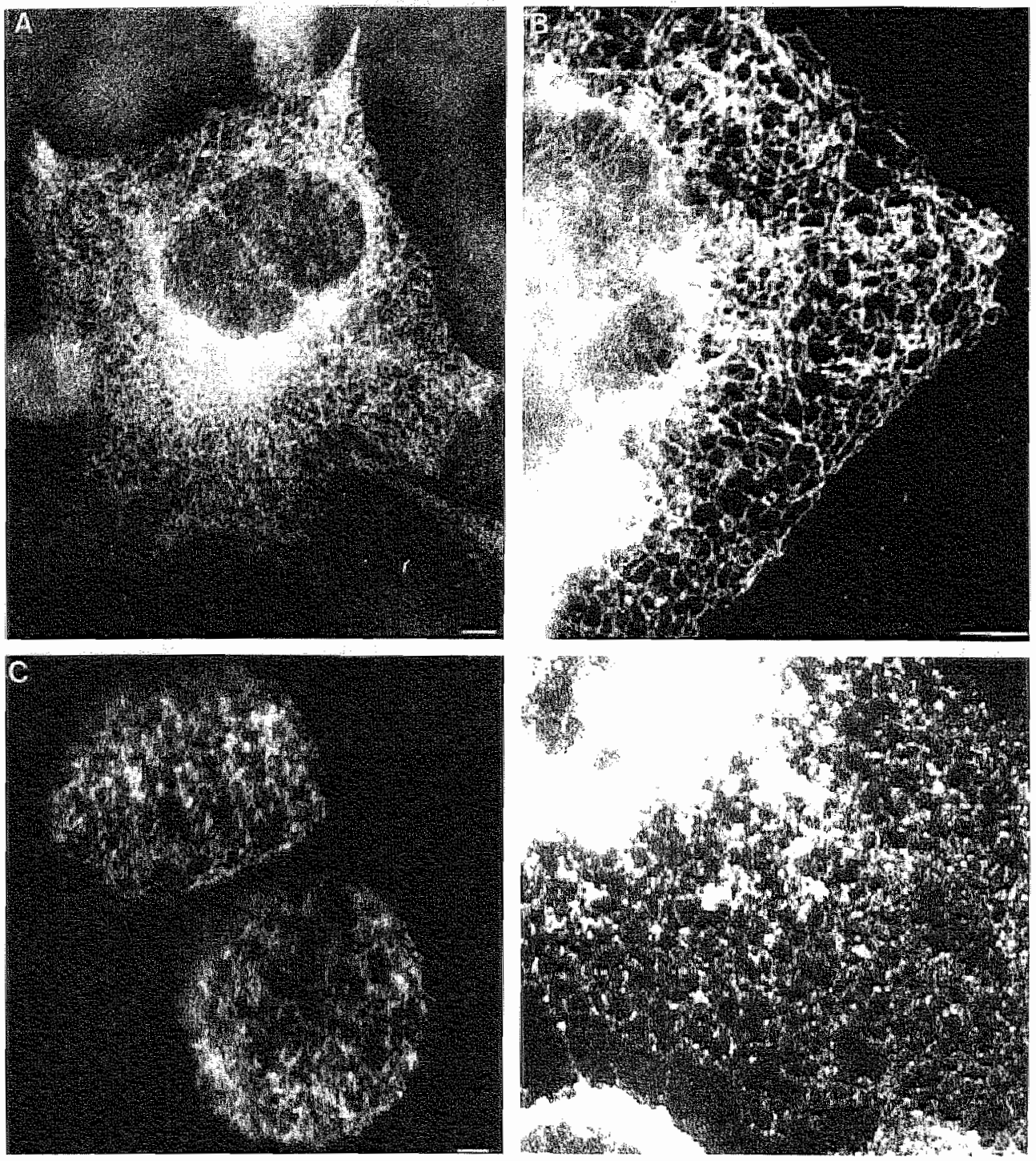

Figure 6. Immunocytochemical localization of NSPs to the endoplasmic reticulum in NCI-H524-A (A and D), NCI-H82 (B) and NCI-H82-A (C). Cells were stained with monoclonal antibody RNL-2 (A and C), with polyclonal antibody POL-1 (B) or with monoclonal antibody IIDB directed towards SERCA2b (D). Bars: $5 \mu \mathrm{m}$. 
Double-label immunofluorescence studies of NSPS and SERCA2b showed overlapping staining patterns in the same cells for both constituents (Fig. 7). Double-label immunofluorescence studies performed with NSP antibodies and a polyclonal antiserum to synaptophysin, a marker protein for small NE vesicles, showed different distribution patterns (Fig. 8). Colocalization studies performed with antibodies to actin, neurofilaments, vimentin and cytokeratins showed no clear overlap in immunostaining. However, partial colocalization of microtubules and NSPs was observed (data not shown; compare [20]).
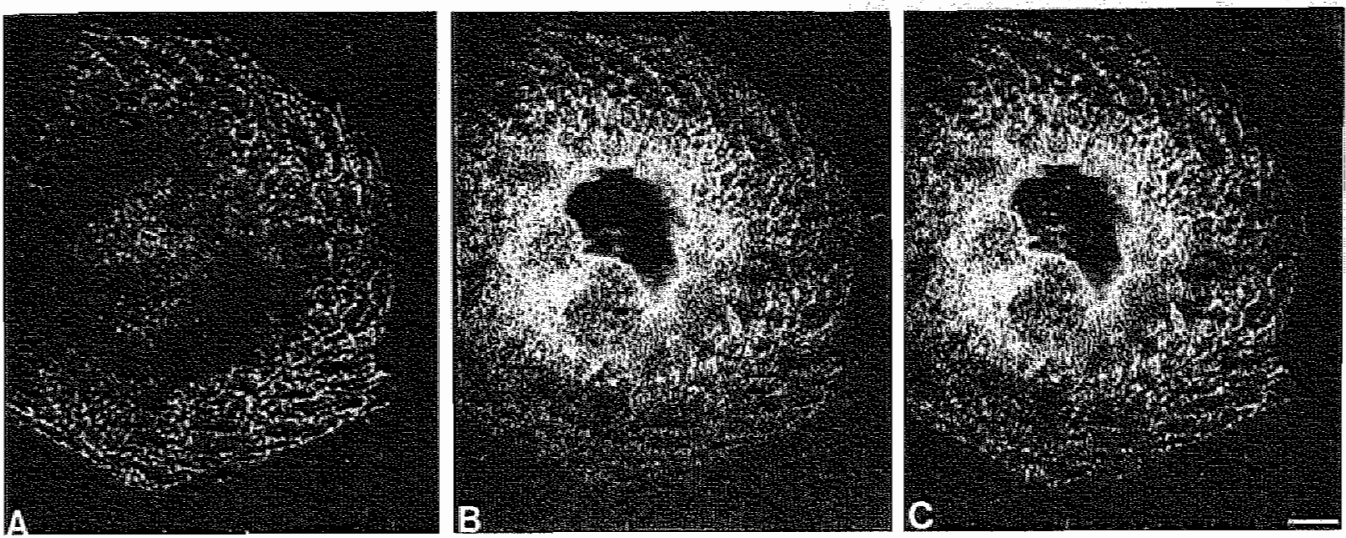

Figure 7. Confocal laser scanning microscopy of double-labeled. NCI-H460 cells, incubated with (A) polyclonal NSP-antiserum POL-1 (green) and (B) monoclonal antibody IHD8 to SERCA2b (red).

(C) Merged images of (A) and (B). Bar: $5 \mu \mathrm{m}$. For color illustration see p 157.

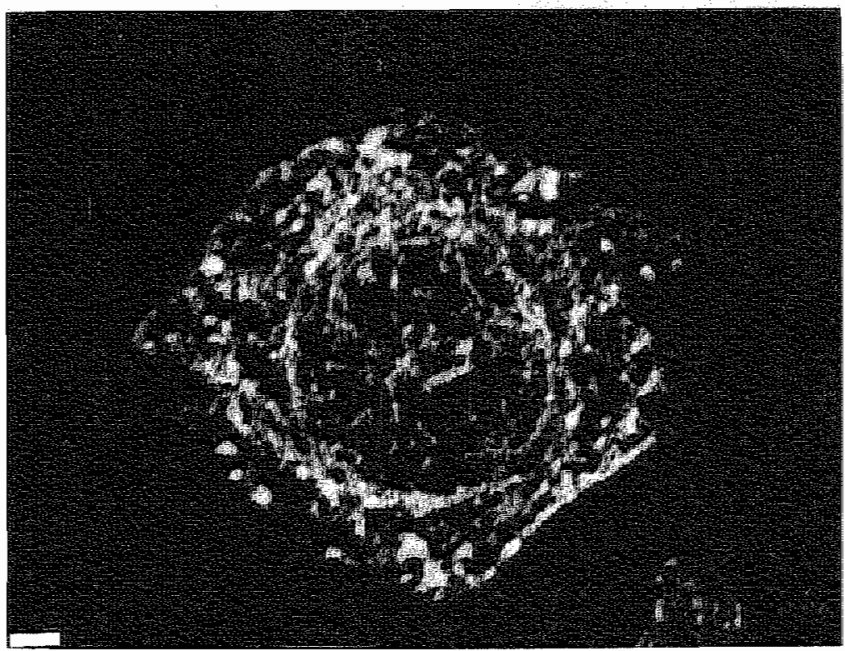

Figure 8. Confocal laser scanning microscopy of double-labelled NCI-H524-A cells incubated with RNL-2, visualised by FITC, and the polyclonal rabit antiserum to synaptophysin, visualised by Texas Red. Bar: $5 \mu \mathrm{m}$.

For color illustration see p 157.

In COS-1 cells transfected with NSP-B cDNA constructs a lace-like network could be seen most explicitly in the cellular periphery after immunostaining with RNL-2 and 
RNL-3 (Fig. 9a) or POL-1 (Fig. 9b), similar to the patterns observed in the SCLC cell lines. This typical staining pattern suggests that also NSP-B is associated with the ER. Special attention should be paid to the dot-like pattern of immunofluorescence at the ER, suggesting the assembly of NSP-B as aggregates at these membranes (Fig. 9c). The COS-1. cells transfected with NSP-B were negative for MON 160- 162 (NSP-A) and POL-8, the polyclonal antiserum specific for NSP-C.
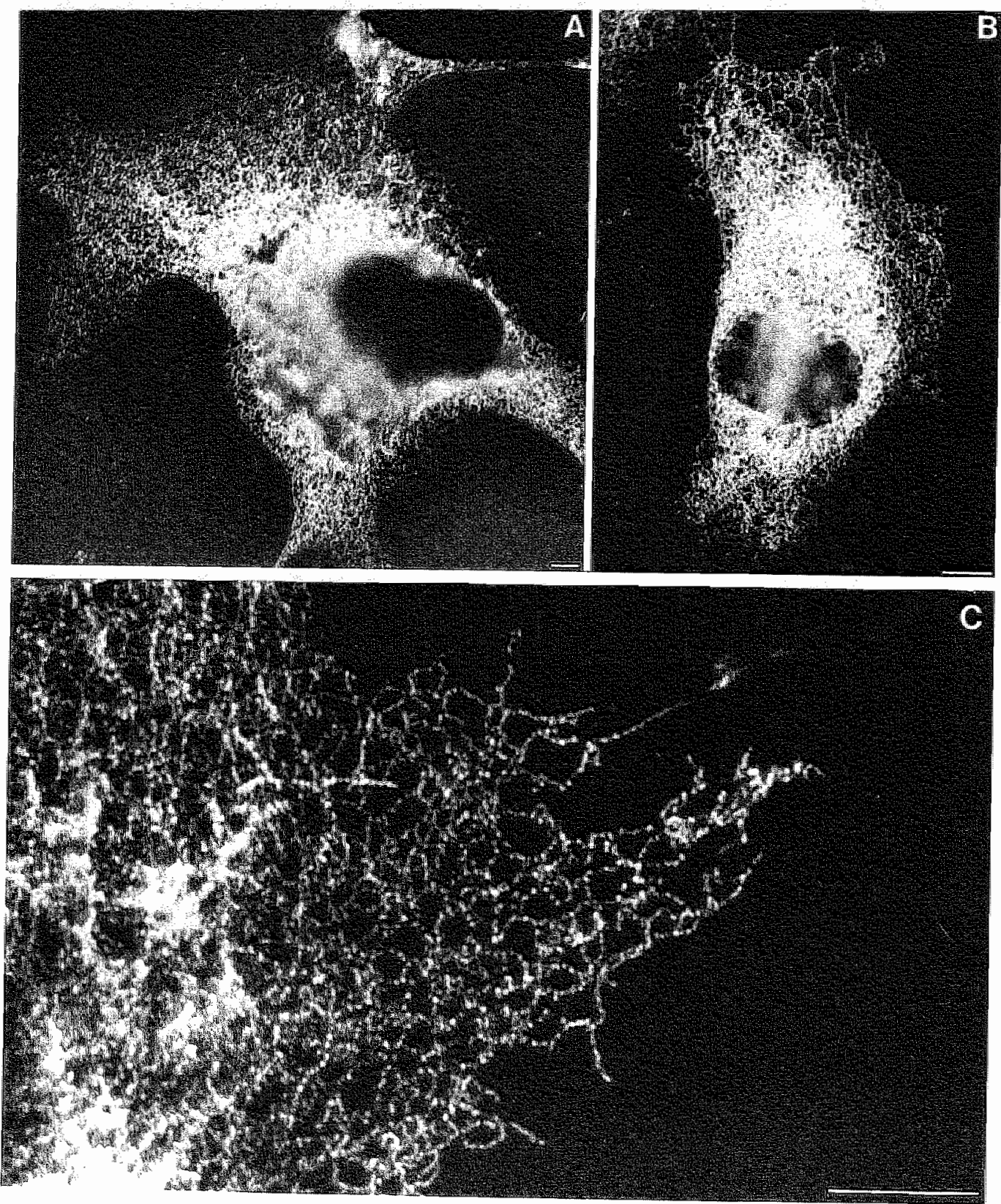
Gel filtration. Gel filtration experiments were performed with the PBS soluble 100 , $000 \mathrm{~g}$ fraction $\mathrm{S} 4$ of $\mathrm{NCI}-\mathrm{H} 82$ and SCLC- $21 \mathrm{H}$ cells as well as with the Triton X-100 soluble fraction S3 (Fig. 10a), containing almost all NSPs, extracted from membranes of the low speed pellet P1. ELISA assays of the amount of antigen found in the different gel filtration fractions, showed that NSP reactivity was exclusively present in the void volume fractions, containing complexes and constituents with a Mw over 500 $\mathrm{kDa}$ (Fig. 10a). The elution profile of the PBS soluble NSPs (without Triton X-100) and the elution profile in the presence of Triton X-100 (with or without Triton X-100 in the running buffer) were identical, thus excluding a role of micelles formation in determining the Mw of the nascent NSP aggregates. Immunoblotting studies of gel filtration fractions, derived from extracts of NCI-H82 cells clearly show the presence of NSP-A and NSP-B in the void volume fractions of the column (Fig. 10b). When extracts from SCLC-21H cells were used only NSP-A was detected in the void volume peak (data not shown).
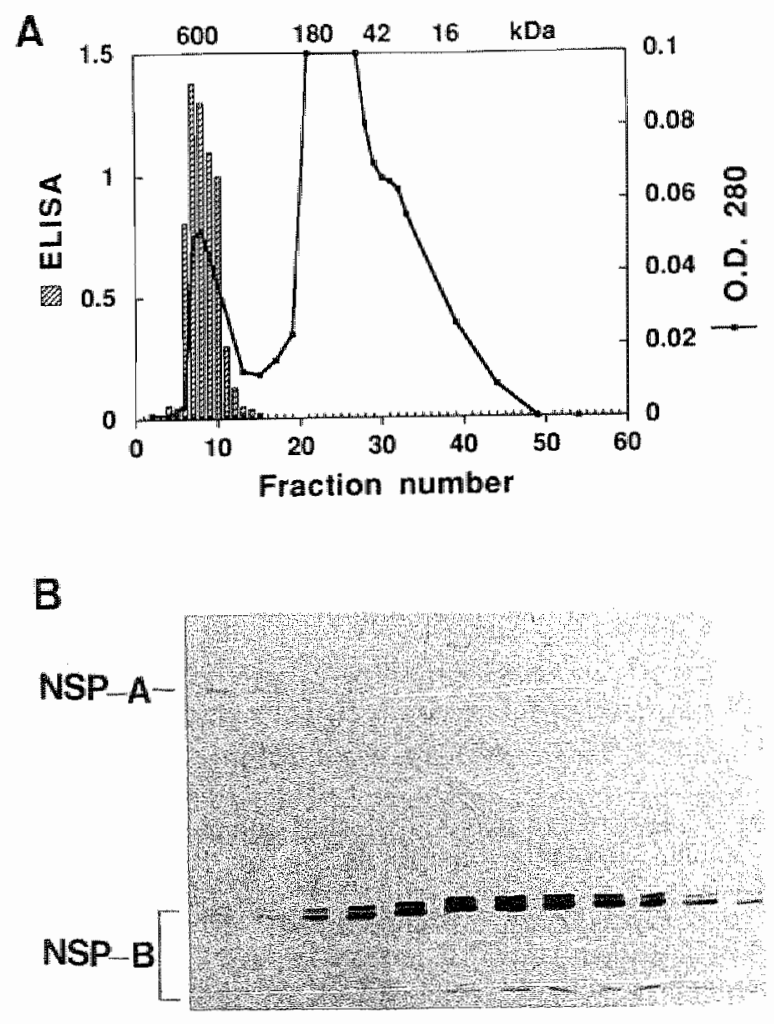

Figure 10. Gell filtration of NSPs. (A) Gel filtration elution profile as measured by $\mathrm{OD}^{280}$ of soluble fraction $\mathrm{S3}$ of $\mathrm{NCl}-\mathrm{H} 82$ cells. ELISA positivity of the different gel filtration fractions are indicated in the figure as bars. At the top of the figure the estimated molecular weight based on the relative position of the calibration proteins is shown. ELISA positivity appeared to be confined to gel filtration fractions 4 to 15 corresponding to the void volume peak of the column.

(B) Detection of NSPs in the gel filtration fractions 4 to 15 of the void volume peak steter size fractionation in a $10 \%$ SDS poly-acrylamide gel and immunobloting, using R NL-3 followed by a mixture of MON 160 162.

Figure 9 Immunocytochemical localisation of NSP-B in COS-1 cells transfected with NSP-B CDNA using RNL-2 (A) and POL-1 (B) (C) Detail showing dot-like aggregates associated with the endoplasmic reticulum, detected by a mixture of RNL-2 and RNL-3. Bars $5 \mu \mathrm{m}(A, B), 10 \mu \mathrm{m}(C)$. 
Immunoaffinity chromatography: To study the nature of the NSP complexes, we investigated whether or not NSP-A and NSP-B are present within the same complex or occur separately. For this purpose the immunoaffinity column of MON 160-162 was loaded either with the Triton X-100 soluble fraction of total NCI-H82 cells (Fig. 11, lane 1) or with the PBS soluble fraction (data not shown). The $135 \mathrm{kDa}$ NSP-A seemed to be complete bound to the affinity column as concluded from the observation that both the eluent and the subsequent wash fraction did not contain this component anymore (Fig. 11, lanes 2 and 3). After extensive washing of the affinity column and subsequent elution of the bound proteins at $\mathrm{pH} 2.5$ it became obvious that the MON 160-162 antibodies, specifically recognizing NSP-A, could retain also NSP-B to the affinity column (Fig. 11, lane 4).

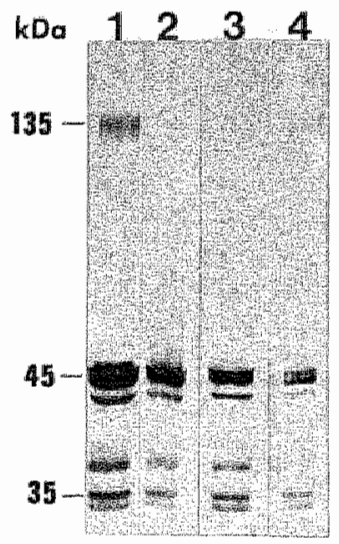

Figure II Immunoaffinity chromatography of NSP' complexes from NCL-H82 Triton X-100 soluble fracion S3 captured by MON 160-162 followed by detection with RNL-3. Lane 1) total Triton $X-100$ soluble fraction applied to the immunoaffinity column; lane 2) unbound eluent; lane 3) Triton X-100 wash fraction; lane 4) eluted fraction at $\mathrm{pH} 2.5$.

Immunoprecipitation. Immunoprecipitation analyses with the $100,000 \mathrm{~g}$ supernatant of the PBS soluble cell fraction of NCI-H82 cells showed that after incubation with RNL2, NSP-A and NSP-B can be detected in immunoblots of the immunoprecipitate when stained with RNL-3 (Fig. 12, lane 1). Immunoprecipitation with a cocktail of mabs MON 160-162 showed also the precipitation of both NSP-A and NSP-B from the PBS soluble fraction of NCI-H82 cells (Fig, 12, lane 2), showing that an antibody specific for NSP-A can also coprecipitate NSP-B from extracts that contain native, intact NSPoligomers.

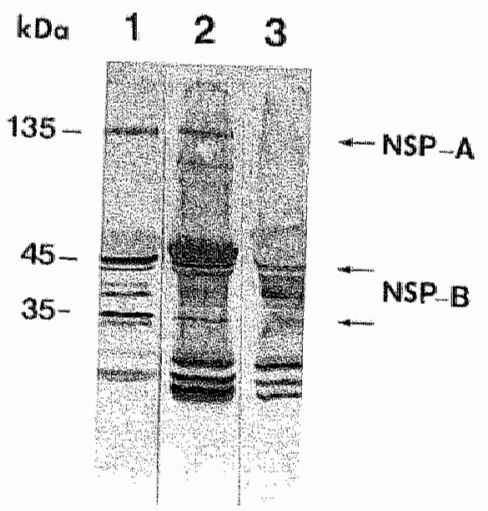

Figure 12 Immunoprecipitation of NSP complexes from the PBS soluble $100,000 \mathrm{~g}$ supernatant $\mathrm{S4}$ of $\mathrm{NCI}-\mathrm{H} 82$ cells followed by electrophoretic separation and immunobloting. NSPS were either immunoprecipitated with a mixture of RNL2 and RNL-3 (lane 1), with a mixture of MON 160-162 (lane 2) or with a control serum RKSE 60 directed towards cytokeratin 10 , absent in NCl-H82 cells (lane 3 ). NSPs were visualised using RNL-3. Note specific NSP-bands at $135 \mathrm{kDa}$, $45 \mathrm{kDa}$ and $35 \mathrm{kDa}$, as denoted by arrows. Other bands occurring in these lanes are due to interaction of the alkaline phosphatase conjugated secondary antibody with the mouse Igsubunits, which were present in the immunoprecipitate. 


\section{DISCUSSION}

In this study, we have biochemically characterized the neuroendocrine-specific proteins (NSPs), that occur in lung cancer cells, with special emphasis on NSP-B. So far, expression of NSP-B has been found only in the thuman SCLC cell line NCI-H82, which was initially used to generate antibodies to the NE type of lung cancer [4]. This resulted in mabs RNL-2 and RNL-3, which not only recognize NSP-B, but also NSP-A [2]. As shown in this study, RNL-2 and RNL-3 recognize epitopes located in the Nterminal half of NSP-B, between amino acids $47-138$, which corresponds to amino acids 467-558 of NSP-A. The antibodies do not recognize NSP-C. Antibodies RNL-2 and RNL-3 recognize several protein bands in the Mw region where NSP-B can be expected. These mainly comprise a $43-45 \mathrm{kDa}$ protein triplet in combination with a 35 $\mathrm{kDa}$ protein. These bands with the same Mw can also be detected in COS-1 cells transfected with NSP-B cDNA and subjected to immunoprecipitation with a mixture of mabs RNL-2 and RNL-3. This result strongly indicates that the NSPs in the $35-45 \mathrm{kDa}$ Mw region all arise from the NSP-B transcript. The observed difference with the calculated $\mathrm{Mw}$ of $39 \mathrm{kDa}$, as deduced from the sequence of the $2.3 \mathrm{~kb}$ transcript can partly be explained by the acidic nature of the protein. In addition, different levels of phosphorylation, as concluded from two-dimensional immunoblotting may explain these differences. The $44-45 \mathrm{kDa}$ protein doublet appeared to be phosphorylated, while previous studies also showed that these proteins are not glycosylated [21]. Presumably, the $35 \mathrm{kDa}$ protein and additional protein bands, regularly found to migrate between the 35 and $43 \mathrm{kDa}$ proteins and to react with NSP-B antibodies, are amino-terminally truncated forms. The assumption is made from the suggestion that the more basic pl of the $35 \mathrm{kDa}$ protein compared with the $43-45 \mathrm{kDa}$ protein triplet, is a result of the loss of acidic residues, which are located in a high concentration at the amino-terminal end of the NSP-B, while the carboxy-terminal part of the protein is relatively basic. Furthermore, minor NSP-B proteins with $\mathrm{Mw}$ between 35 and $43 \mathrm{kDa}$, show a pI between that of the $35 \mathrm{kDa}$ protein and the 43-45 $\mathrm{kDa}$ triplet. Since the epitopes of antibodies RNL-2 and RNL-3 occur in the amino-terminal part of NSP-B, our assumption of the smaller NSP-B constituents being amino-terminally truncated is confirmed by the observation that no NSP-B protein bands smaller than $35 \mathrm{kDa}$ can be detected by these two antibodies. Concordantly, the main epitopes for the rabbit antiserum POL-1 are probably located closer to the amino-terminus since this antibody recognizes only NSP-B proteins larger than $43 \mathrm{kDa}$.

In previous studies we have found that NSPs are present in the $100,000 \mathrm{~g}$ supernatant of $\mathrm{NCI}-\mathrm{H} 82$ cells, and may be arranged in large proteinaceous complexes with a $\mathrm{Mw}$ of more then $500 \mathrm{kDa}$ [4]. Our present studies indicate, however, that also a major portion of both NSP-A and NSP-B can be found in the membranous fraction of these cells from which the NSPs can be solubilized with Triton X-100. Gel filtration studies have shown that the NSPs, extracted from these membranous structures by Triton X100 , still form large aggregates of more than $500 \mathrm{kDa}$. Since immunofluorescence studies in lung cancer cells and COS-1 cells transfected with NSP CDNA show an association of these aggregates with the ER, we designated these complexes NSPreticulons [21]. Immunoprecipitation analyses indicate that in NCI-H82, these NSPreticulons can consist of heteropolymers, containing both NSP-A and NSP-B. Also the protein complexes found in the cytoplasm, seem to comprise both NSP-A and NSP-B 
as confirmed by additional immunoaffinity experiments. However, also homomers can be formed by NSP-A or NSP.B alone. An indication of a possible formation of homomeric structures comes from transfection studies in COS-1 cells with NSP-B cDNA, which show that these proteins alone are capable of forming typical dot-like aggregates at the $E R_{y}$ similar to the original complexes. It is unclear, however, how these large complexes are composed and to what extent they contain constituents other than the NSPs. Silver staining and gold staining of immunoaffinity-purified complexes revealed no other major protein bands. Our findings taken together suggest that in NCI-H82 cells, NSPs are mainly assembled into complexes (possibly with several other proteins), which are associated with membranes of the ER and occur to a much lesser extent in the soluble fraction of the cytoplasm. Since the NSPs are tightly associated with the ER and can not be extracted by high salt or alkaline treatment [21], the soluble fraction might represent a distinct complex of NSPs. Future immunoelectron microscopy studies will have to reveal the exact location and orientation of these NSP-reticulons.

NSP expression is mainly found in neural and NE cell types, as well as in neuroendocrine tumours $[1,2,4]$. To a certain extent, NSP-expression resembles the tissue distribution pattern described for the chromogranins and secretogranins, proteins found in the "dense-cored" secretory granules in normal and neoplastic NE cells [22]. Similarly, NSP tissue distribution overlaps partly with that of synaptophysin, an integral membrane protein of small NE vesicles [22]. However, no subcellular colocalization of NSPs with synaptophysin has been found in this study. In NCIH524A cell cultures the NSP-antibodies showed a broader reaction than the synaptophysin antiserum. Although sequence similarities are not obwious, the NSPs do exhibit some features also found in other NE proteins. In their carboxy-terminal parts, which are identical in all NSPs, two hydrophobic regions are present which most likely constitute membrane-anchoring domains. The NSPs have no signal peptide [1]. Analysis of deletion mutants have shown that the hydrophobic carboxy-terminal region is critical for membrane binding [21]. A new class of membrane proteins with a C-terminal anchor has been described, which lack a signal peptide but which do have hydrophobic C-terminal sequences, called insertion sequences, structurally similar to signal sequences [23]. Comparison of sequence data has so far not revealed the presence of such domains in NSPs. Like amphiphysin, a synaptic vesicle-associated protein, the NSPs are very acidic, are rich in proline residues, contain potential sites for phosphorylation and lack a signal peptide [24]. Abundant acidic amino acid stretches are also present in chromogranin A and B [22]. In contrast, another common feature of NE proteins such as the C-terminal flanking peptide of gastrin releasing polypeptide, calcitonin and 7B2 is that they are constituents of or associated with secretory vesicles or granules and not with the ER as observed for NSPs [25-28]. Immunohistochemical studies in normal tissues and tumors will have to reveal whether or not NSPs can be used as reliable markers for NE differentiation.

\section{Acknowledgements}

The authors thank RI Linnoila (Rockville, MD, USA), G Bepler (Durham, NC, USA), D Carney (Dublin, Ireland), H Oie (NCI, Rockville, MD, USA) for providing cell lines. Dr K Campbel] (lowa City, IA, USA) for the antiserum against $\mathrm{Ca}^{2+}$-ATP-ase, $M$ Borgers (Janssen Pharmaceutics, Beerse, Belgium) for the antiserum to tubulin, J Askaa (DAKO A/S, Glostrup, Denmark) for the antiserum 
against synaptophysin. B. Schutte is acknowledged for his help with CSLM and M. Hentling for technical assistance. This work was supported by the Netherlands Cancer Foundation, grant no. IKL. 90-09 and in part by the "Nationaal Fonds woor Wetenschappelijk Onderzoek (NFWO) and the " Geconcerteerde Onderzoekacties 1992-1996".

\section{REFERENCES}

1. Roebroek AJM, van de Velde HJK, Van Bokhoven A, Broers JLV, Ramaekers FCS, Van de Ven WJM. Cloning and expression of alternative transcripts of a novel neuroendocrine-specific gene and identification of its 135-kDa translational product. J Biol Chem 268: 13439-13447, 1993.

2. Senden NHM, van de Velde HJK, Broers JLV, Timmer EDJ, Roebroek AJM, Van de Ven WJM, Ramaekers FCS. Cluster-10 lung cancer antibodies recognize NSPs, novel neuroendocrine proteins associated with membranes of the endoplasmine reticulum. Int J Cancer suppl 8: 84-88, 1994.

3. Kools PFJ, Roebroek AMM, van de Velde HJK, Marynen P, Bullerdiek J, Van de Ven WJM. Regional mapping of the human NSP gene to human chromosome region $14021<22$ by thorescence in situ hybridization analysis. Cytogenet Cell Genet 66: 48-50, 1994.

4. Broers JLV, Mijnheere EP, Klein Rot M, Schaart G, Sijlmans A, Boerman OC, Ramaekers FCS. Novell antigens characteristic of neuroendocrine malignancies. Cancer 67: 619-633, 1991.

5. Van de Velde HJK, Senden NHM, Roskams TAD, Broers ILV, Ramaekers FCS, Roebroek AJM, Van de Ven WJM. NSP-encoded reticulons are neuroendocrine markers of a novel category in human lung cancer diagnosis. Cancer Res 54, 4769-4776, 1994.

6. Lan MS, Russell EK, Lu J, Johnson BE, Notkins AL. IA-1, a new marker for neuroendocrine differentiation in human lung cancer cell lines. Cancer Res 53: 4169-4171, 1993.

7. Broers JLV, KIein Rot M, Oostendorp T, Bepler G, de Leij L, Carney DN, Vooijs GP, Ramaekers FCS. Spontaneous changes in intermediate filament protein expression patterns in lung cancer cell lines. J Cell Sci 91: 91-108, 1988.

8. Bepler G, Jaques G, Neuman K, Aumüller G, Gropp C, Havemann K. Establishment, growth properties, and morphological characteristics of permanent human small cell lung cancer cell lines. J Cancer Res Clin Oncol 113: 31-40, 1987.

9. Brower M, Carney DN, Oie HK, Gazdar AF, Minna JD. Growth of cell lines and clinical specimens of human non-small cell lung cancer in a serum-free defined medium. Cancer Res 46 : $798-806,1986$.

10. Gazdar AF, Carney DN, Nau MM, Minna JD. Characterization of variant subclasses of cell lines derived from small cell lung cancer having distinctive biochemical, morphological, and growth properties. Cancer Res 45: 2924-2930, 1985.

11. Van Duijnhoven ILP, Creemers JWM, Kranenborg MGC, Timmer EDJ, Groeneveld A, Van den Ouweland AMW, Roebroek AJM, Van de Ven WJM. Development and characterization of a panel of monoclonal antibodies against the novel subtilisin-like proprotein processing enzym furin. Hybridoma 11: $71-86,1992$.

12. Van de Velde HJK, Roebroek AJM, Van Leeuwen FW, Van de Ven WIM Molecular analysis of expression in rat brain of NSP-A, a novel neuroendocrine-specific protein of the endoplasmic reticulum. Mol. Brain Res 23: 81-92, 1994.

13. Jorgensen AO, Arnold W, Pepper DR, Kahl SD, Mandel F, Campbeil KP. A monoclonal antibody to the $\mathrm{Ca}^{2+}$-ATPase of cardiac sarcoplasmic reticulum cross reacts with slow type I but not with fast type II canine skeletal muscle fibers: an immunocytochemical and immunochemical study. Cell Motil Cytoskel 9: 164-174, 1988.

14. Laemmli UK. Cleavage of structural proteins during the assembly of the head of bacteriophage T4. Nature 227: 680-685, 1970.

15. O'Farrell PH. High resolution two-dimensional gel electrophoresis of proteins. B Biol Chem 250: $4007-4021,1975$.

16. Spindler KR, Rasser DS, Berk AJ. Analysis of adenowitus transforming proteins from early regions $1 \mathrm{~A}$ and $1 \mathrm{~B}$ with antisera to inducuble fusion antigens produced in Escherichia coli. $J$ Virol 49: 132-141, 1984.

17. Luthman H, Magnusson G. High efficiency polyoma DNA transfection of chloroquine treated cells. Nucleüc Acids Res 11: 1295-11308, 1983.

18. Bloemendal H. The lens proteins. In: Molecular and cellular biology of the eye lens. John Wiley \& Sons, New York, pp. 1-47, 1981. 
19. Smith PK, Krohn M, Hermanson GT, Mallia AK, Gartner FH, Provenzano MD, Fujimoto EK, Goeke $\mathrm{NM}$, OHon BJ, Klenk DC. Measurement of protein using bicinchoninic acid. Anal Bitochem 150:76-85, 1985 .

20. Terasaki M, Chen LB, Fujiwara K. Microtubules and the endoplasmic reticulum are highly interdependent structures. J Cell Biol 103: 1557-1568, 1986.

21. Van de Velde HJK, Roebroek AJM, Senden NHM, Ramaekers FCS, Van de Ven WJM. NSPReticulons, neuroendocrine proteins of a novel geme family assiociated with membranes of the endoplasmic reticulum. I Cell Se 107: 2403-2416, 1994.

22. Wiedenmann B, Huttner WB. Synaptophysin and chromogranins/secretogranins - widespread constituents of distinct sypes of neuroendocrine vesicles and new tools in tumor diagnosis. Virchows Archiw B Cell Path 58: 95-121, 1989.

23. Kutay U, Hartmann E, Rapoport TA. A class of membrane proteins with a C-terminal anchor. Trends in Coll Biol 3: 72-75, 1993 .

24. Lichte B, Veh RW, Meyer HE, Kilimann MW. Amphiphysin, a novel protein associated with synaptic vesicles. EMBO J 11: 2521-2530, 1992.

25. Cutz E, Chan W, Track NS. Bombesin, calcitonin and leu-enkephalin immunoreactivity in endocrime cells of human llung. Experientia 37: 765-767, 1981.

26. Roebroek AIM, Martens GIM, Duits AJ, Schalken JA, Van Bokhoven A, Wagenaar SSc, Van de Ven WJM. Differential expression of the gene encoding the novel pituitary polypeptide $7 \mathrm{~B} 2$ in human lung cancer cells. Cancer Res 49: 4154-4158, 1989.

27. Said JW, Vimadalal S, Nash G, Shintaku IP, Heusser RC, Sassoon AF, Lloyd RV. Immuno* reactive neuron-specific enolase, bombesin, and chromogranin as markers for neuroendocrine lung tumors. Hum Path 16: 236-240, 1985 .

28. Sheppard MN, Corrin B, Bennett MH, Marangos PJ, Bloom SR, Polak JM. Immunocytochemical localization of neuron specific enolase in small cell carcinomas and carcinoid tumours of the lung. Histopath 8: 1714181, 1984. 


\title{
NEUROENDOCRINE-SPECIFIC PROTEIN C (NSP-C): SUBCELLULAR LOCALIZATION AND DIFFERENTIAL EXPRESSION IN RELATION TO NSP-A
}

\begin{abstract}
Nicole HM Senden, Erika DJ Timmer, James E Boers, Helgi JK van de Velde, Anton JM Roebroek, Wim JM Van de Ven, Jos LV Broers, Frans CS Ramaekers
\end{abstract}

Eur J Cell Biol, in press

\section{ABSTRACT}

A mouse monoclonal antibody (mab) RNL-4, as well as a rabbit polyclonal antiserum POL-8 were raised against a synthetic peptide, encompassing the first twenty unique amino-terminal amino acid residues of NSP-C. The specificity of both immunoreagents was established in an enzyme-linked immunosorbent assay (ELISA) using the synthetic peptide and by their immunoreactivity to NSP-C fusion proteins. Immunofluorescence analysis of COS-1 cells, transfected with NSP-C cDNA, showed staining of the endoplasmic reticulum (ER) with RNL-4 and POL-8. No cross-reactivity of these reagents with NSP-A or NSP-B was seen. Immunohistochemical studies in normal human tissues showed expression of NSP-C in tissues of neural and neuroendocrine (NE) origin i.e. neurons of the central and peripheral nervous system, the neurohypophysis, adrenal medulla, adenohypophysis, pars intermedia and in sporadic NE cells of the lung. Expression of NSP-C was found in several small cell lung cancer (SCLC) cell lines, in non-SCLC cell lines with NE features, but not in typical non-SCLC cell lines. Also, in a neuroblastoma cell line NSP-C expression was observed. Immunoblotting and immunoprecipitation studies with RNL-4 and POL-8 identified the $23 \mathrm{kDa}$ NSP-C polypeptide in these cell lines. Immunofluorescence microscopy showed that also in these cell lines NSP-C is located at the ER, as shown before for NSP-A and NSP-B. In some of the cell lines coexpression of NSP-A and NSP-C was observed, while in others only one of the two could be detected. The differential expression of NSP-A and NSP-C in these cell lines is confirmed by immunoblotting and was also evident at the mRNA level. When NSP-A and NSP-C were coexpressed the number of NSP.C positive cells was always less than the number of NSP-A positive cells. A partial colocalization of NSPS was observed in the ER. Cell fractionation studies revealed that both proteins are retained in the membranous fraction of the cell, from which they can be solubilized by Triton X-100. Immunoprecipitation analyses under native conditions indicate that NSP-C does not need to associate with NSP-A to form high molecular weight (Mw) NSP-reticulons. 


\section{INTRODUCTION}

Previous studies have established that transcription of the NSP-gene can result in mRNAs of $3.4,2.3$ and $1.8 \mathrm{~kb}$ [1]. These transcripts encode three carboxy-terminally overlapping proteins i.e. NSP-A (135 kDa), NSP-B (a set of proteins with Mw ranging from 35 to $45 \mathrm{kDa})$ and NSP-C $(23 \mathrm{kDa})$. NSP-A and NSP-C contain unique aminoterminal sequences of 420 and 20 amino acids, respectively. The expression of these two components is largely restricted to NE and neural tissues $[2,3]$. NSP.B, which is identical to the carboxy-terminal half of NSP-A, has so far only been found in the NE small cell lung cancer (SCLC) cell line NCI-H82. NSPs can form large aggregates and are associated with the ER in NE cell types, the common carboxy-terminal end of all three subtypes being responsible for membrane anchoring $[4,5]$. Because of this subcellular localization we refer to these protein aggregates as NSP-reticulons. Monoclonal and polyclonal antibodies directed against the different NSP subtypes were generated. A set of antibodies, specific for NSP-A, has been obtained $[5,6]$. As a consequence of the primary structure of their antigens, antibodies recognizing NSP-B also recognize NSP-A. Strikingly, no antibodies could sofar be generated to the membrane anchoring, carboxy-terminal part of NSPs. Also the production of immunoreagents specific for NSP-C has been cumbersome. Repeated immunizations, using bacterially expressed NSP-C hybrid proteins were unsuccessful. A polyclonal rabbit antiserum to NSP-C (POL-8), could be raised against a synthetic peptide comprising its unique amino-terminus, but the reactivity patterns of this reagent have only been described to a limited extent [5]. In this study, we describe the development and characterization of a mab RNL-4, with specificity for NSP-C, also generated by immunization with a synthetic peptide encompassing the unique twenty amino acid sequences of NSP-C. Using both the polyclonal and the monoclonal antibody to NSP-C its expression pattern was studied in relation to NSP-A. First, in order to establish the tissue distribution of NSP-C we have performed immunohistochemical analysis of various normal human tissues. We show that NSP-C is selectively expressed in neural tissue and in a small subset of NE tissues, not completely overlapping with NSP-A. Furthermore, these immunohistochemical results were confirmed in studies with cell lines of different tissue origin. Second, we have further investigated the subcellular distribution of NSP-C in relation to NSP-A by double immunofluorescence microscopy. Similar immunoreactivity patterns i.e. staining of the ER, could be seen for both NSP-A and C, while differential cell fractionation experiments revealed that NSP-C behaved comparably to NSP-A. Third, we wondered whether or not NSP-C can associate with NSP-A to form the large reticulon aggregates as shown before for NSP-B and $-A$ [4]. Therefore, immunoprecipitation assays were performed under native conditions, which indicated that NSP-A and NSP-C do not form heteropolymers.

\section{MATERIALS AND METHODS}

\section{Cell lines}

The human lung cancer cell lines used in this study included the SCLC cell lines GLC1, GLC-1-M13, SCLC-21H, SCLC-16HV, SCLC-16HC, NCI-H82, NCI-H69, NCIH249, NCI-H524; the non-SCLC cell lines LCLC-103H, NCI-H125, MR-65 and the 
non-SCLC cell lines with NE characteristics (non-SCLC-NE) NCI-H460, NCI-H810 and NCI-H1155. Establishment and characterization of these lung cancer cell lines have been described [7-14]. The three non-SCLC-NE cell lines are furthermore characterized in Senden et al.: NSP-reticulons as independent markers for non-small cell lung cancer with neuroendocrine differentiation (submitted). All cell lines, except for MR-65, were grown in RPMI-1640 medium (Gibco BRL, Paisley/Scotland) supplemented with $10 \%$ newborn calf serum (Gibco), 1\% L-glutamin (Serva, Heidelberg/Germany) and $0.1 \%$ gentamycin (AUV, Cuyk/The Netherlands). The cell line MR-65 was grown in Eagle's modified minimal essential medium (EMEM; Gibco), supplemented with $10 \%$ newborn calf serum, $1 \%$ L-glutamin and $0.1 \%$ gentamycin. Other human cancer cell lines included in this study are the colon cancer cell line NCI-H716 (CCL-251/ATCC, Rockville, Maryland/USA) [15], the bladder carcinoma cell line T24 [16] and two neuroblastoma cell lines CHP-212 [17] and

SK-N-SH (HTB-11/ATCC) [18]. The cell line NCI-H716 was grown in RPMI-1640 medium, T24 in Eagle"s modified minimal essential medium and the two neuroblastoma cell lines in Dulbecco's modified eagle medium (DMEM; ICN Flow, Costa Mesa, CA/USA). All these media were supplemented with $10 \%$ newborn calf serum, $1 \% \mathrm{~L}$-glutamin and $0.1 \%$ gentamycin.

\section{Normal human tissues}

Normal human tissues were obtained during several autopsies, quickly frozen in liquid nitrogen after resection and stored at $-80^{\circ} \mathrm{C}$. They were obtained from the Department of Pathology, University Hospital Maastricht, The Netherlands and the Department of Pathology, Canisius Wilhelmina Hospital, Nijmegen, The Netherlands.

\section{NSP cDNA clones and expression in COS-1 cells}

Cloning and characterization of NSP cDNAs have been described previously [1]. For expression in COS-1 cells NSP cDNA constructs encoding NSP-B and NSP-C were cloned into the Xhol site of PSVL as described before $[1,4]$. The resulting clones were named pSVL-NSP-B and pSVL-NSP-C, respectively. Transfection was performed by DEAE dextran and a chloroquine shock as described previously [1]. NSP expression was studied immunocytochemically $48 \mathrm{~h}$ after transfection.

\section{Production of bacterial hybrid proteins}

The production of bacterial hybrid proteins used in this study has been described before [6]. NSP-cDNA clones were subcloned into the bacterial expression vectors pGEX and pUR. In the pUR-derived expression vectors, the open reading frames of the various NSP-CDNAs were cloned in-frame to the 3 '-end coding sequences of $B$ galactosidase ( $(\mathrm{Gal})$. The translational products were designated BGal-NSP-A, BGalNSP-B and BGal-NSP-C. Cloning of NSP-C DNA sequences into pGEX-2T, resulted in pGEX-NSP-C. In this construct, the NSP-C-encoded sequences are fused in frame to the carboxy-terminal region of glutathione S-transferase (GST). After induction of biosynthesis of the bacterial hybrid proteins, bacteria were lysed in buffer containing

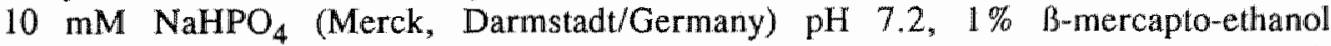
(Merck), $1 \%$ sodium dodecyl sulphate (SDS; Bio-Rad Laboratories, Richmond, CA/USA), 6M ureum (Merck). These lysates were used for ELISA and gel electrophoresis (after addition of sample-buffer). 


\section{Production of mouse monoclonal anti-NSP-C antibody}

RNL-4 was generated by immunization with the synthetic peptide MQATADSTKMDCVWSNWKSQ, which represents the unique 20 amino-terminal residues of NSP-C, not present in NSP-A and in NSP-B. The synthetic peptide was purchased from Research Genetics (Huntsville, AL/USA) and synthesised as a multiple antigen peptide, consisting of single units on a branching lysyl matrix using a solid-phase peptide synthesis method [19]. Balb/c mice were immunized intraperitoneally for the furst immunization with $50 \mu \mathrm{g}$ of the synthetic peptide solubilized in phosphate-buffered saline (PBS; $0.15 \mathrm{M} \mathrm{NaCl}, 10 \mathrm{mM} \mathrm{Na-phosphate,} \mathrm{pH}$ 7.2) and suspended in Specol [20] (Central Veterinary Institute, Lelystad/The Netherlands; 5 parts Specol were add to 4 parts of the antigen solution $(\mathrm{v} / \mathrm{v}))$. Mice were boosted twice, with a two week intervall, with the same solution. Finally, mice were boosted with $25 \mu \mathrm{g}$ of the synthetic peptide sollubilized in PBS without Specol. Three days after the last boost spleen cells were isolated and fused to Sp2/0-Ag14 myeloma cells using polyethylene glycol 1450 (Kodak, Rochester, NY/USA). Hybridomas were selected in HAT medium (Flow, ICN Biomedicals, Costa Mesa, CA/USA). In a first screening for NSP-C reactivity culture supernatants of hybridomas were analyzed using an ELISA assay. Positive hybridoma cultures were subsequently cloned three times by the limiting dilution method and were further screened by immunoblotting of sizefractionated bacterial hybrid proteins and by immunofluorescence analysis of COS-1 cells transfected with NSP cDNAs. Isotyping of the monoclonal antibody was performed by a Mouse Mab Isotyping Kit (Gibco BRL, Gaithersburg, MD/USA). RNL-4 was used undiluted for immunofluorescence microscopy and in a dilution 1:4 for immunoperoxidase microscopy and immunoblotting.

\section{Other antibodies used in this study}

Polyclonal rabbit antiserum POL-8, specific for NSP-C [5], used in a 1: 100 dilution for immunofluorescence microscopy and immunoblotting and in a 1:500 dilution for immunoperoxidase microscopy; mouse mabs MON-160, MON-161 and MON-162 (all of the IgGl subtype). These mabs are specific for NSP-A and are extensively characterized before $[5,6]$. They are used in a 1:1:1 cocktail (MON 160-162) and this mix is used undiluted for immunofluorescence and 1:5 for immunoperoxidase microscopy and immunoblotting; polyclonal rabbit antiserum $\mathrm{POL}-1$, recognizing epitopes present in NSP-A and NSP-B [5], used in a 1:100 dilution for immunofluorescence and immunoblotting and 1:2500 for immunoperoxidase microscopy; mouse mabs RNL-2 and RNL-3 (both IgGl subtype) recognizing epitopes present in NSP-A and NSP-B [4]. These antibodies were used as undiluted culture supernatants for immunofluorescence microscopy and immunoperoxidase microscopy and 1:100 for immunoblotting. The epitope localization of the above mentioned antibodies is summarized in ref. 21; polyclonal rabbit antiserum to synaptophysin (DAKO A/S, Glostrup/Denmark), a component of the membrane of presynaptic vesicles and widely distributed in neurons and NE cells $[22,23]$ is used in a 1:50 dilution for immunoperoxidase microscopy; mouse mab LK2H10 recognizing chromogranin-A (IgGl subtype), available from BioGenex (San Ramon, Ca/ USA). Chromogranin-A is associated with secretory granules of NE cells [22,23], and is diluted 1:100 for immunoperoxidase microscopy; mouse mab IID8 [24] directed against SERCA2b, a $\mathrm{Ca}^{2+}$-ATPase of the ER, kindly provided by Dr.K. Campbell 
(Howard Hughes, Medical Institute, Iowa City, Iowa, USA). This antibody is diluted 1:100 for immunofluorescence microscopy; polyclonal rabbit antiserum to bovine $S$ 100 protein (DAKO A/S), diluted 1:500 for immunoperoxidase microscopy; mouse mab KP1 to CD68 (IgGl subtype) recognizing human macrophages (DAKO A/S), diluted 1:500 for immunoperoxidase microscopy; mouse Mab anti- $\alpha$ sm-1 (DAKO A/S), reactive with $\alpha$-smooth muscle actin [25], diluted 1:10000 for immunofluorescence microscopy and immunoblotting.

\section{ELISA}

For hybridoma screening, the synthetic peptide $(1 \mu \mathrm{g} /$ well) and complete bacterial lysate containing B-Gal-NSP-C $(5 \mu \mathrm{g} /$ well $)$ were diluted in coating buffer $(0.1 \mathrm{M}$ $\mathrm{Na}_{2} \mathrm{CO}_{3}, \mathrm{pH}$ 9.6) and $100 \mu \mathrm{l}$ was coated overnight at $4^{\circ} \mathrm{C}$ on polystyrene flat bottom E.I.A./R.I.A. microtiter plates (Costar, Cambridge, MA/USA). As negative control BGal $\left(1 \mu \mathrm{g} /\right.$ well) was used. After blocking for $1 \mathrm{~h}$ at $37^{\circ} \mathrm{C}$ with $1 \% \mathrm{BSA}$ (Sigma, St. Louis, MO/USA) in PBS, $100 \mu l$ hybridoma culture supernatant was applied per well for $2 \mathrm{~h}$ at $37^{\circ} \mathrm{C}$. After washing with $\mathrm{PBS}$, peroxidase-conjugated rabbit anti-mouse immunoglobulins (Ig; DAKO A/S, Glostrup/Denmark) diluted 1:1500 in 1\% BSA in PBS was applied for $1 \mathrm{~h}$. Antibody binding was detected by addition of $100 \mu \mathrm{l}$ of a fresh substrate solution of $0.04 \%$ ortho-phenylene diamine dihydrochloride (OPD; Sigma) and $0.01 \%$ ( $/ / w)$ hydrogen peroxide in $0.1 \mathrm{M}$ citrate/phosphate buffer, $\mathrm{pH} 5$ to each well. After 20 minutes the reaction was stopped by addition of $50 \mu \mathrm{l} 2.5 \mathrm{M}$ $\mathrm{H}_{2} \mathrm{SO}_{4}$ and the extinction was measured at $492 \mathrm{~nm}$ in a microplate reader model 450 (Biorad laboratories, Richmond, CA/USA). As a positive control POL-8 was used.

\section{Immunocytochemistry}

Immunoperoxidase procedure: Frozen sections $(4-6 \mu \mathrm{m})$ were cut on a cryostat, air dried and fixed in acetone $\left(-20^{\circ} \mathrm{C}\right)$ for 10 minutes. The indirect peroxidase technique was performed as described previously [26]. The sections were incubated with the primary antibodies for $1 \mathrm{~h}$ in the appropriate dilutions in PBS as described above. After repeated washing in PBS, sections were incubated for $1 \mathrm{~h}$ with peroxidase conjugated rabbit anti-mouse immunoglobulins (Ig; DAKO A/S) or with peroxidase conjugated swine anti-rabbit $\lg$ (DAKO A/S), both diluted 1:100 in PBS containing 5\% human $\mathrm{AB}$ serum. For the detection of NSP antibody binding also biotinylated $\mathrm{F}\left(\mathrm{ab}^{\prime}\right)_{2}$ fragment of rabbit-anti-mouse $\mathrm{Ig}$, followed by streptavidin coupled to peroxidase was applied. After washing in PBS or in $0.1 \%$ Tween 20 and $1 \%$ BSA in PBS (for the streptavidin procedure), peroxidase activity was detected with 3-amino-9-ethylcarbazole (AEC; Sigma) or with 3,3' diaminobenzidine (DAB; Sigma). Sections were counter stained with haematoxylin, mounted with Kaisers glycerol gelatin (Merck) and viewed with a Zeiss Axiophot microscope (Zeiss Oberkochen/Germany). Photographs were made using a 64 ASA EPY $T$ film (Kodak). In the negative controls the primary antiserum was replaced by PBS.

Indirect immunofluorescence microscopy: The procedures of indirect immunofluorescence microscopy have been described before [4]. All cells were fixed by dipping in $20^{\circ} \mathrm{C}$ methanol (Merck) for $5 \mathrm{sec}$, followed by 3 dips in $4^{\circ} \mathrm{C}$ acetone (Merck) $5 \mathrm{sec}$ each. After air drying, cells were incubated with the NSP antibodies in the appropriate 
dilutions in PBS for $1 \mathrm{~h}$. In the negative control incubations the primary antibody was replaced by $\mathrm{PBS}$ or by a non-relevant antiserum.

\section{Cell fractionation}

After harvesting of the cells at $200 \mathrm{~g}$ for $5 \mathrm{~min}$ and washing in PBS $\left(4^{\circ} \mathrm{C}\right)$, cells were resuspended in PBS $\left(4^{\circ} \mathrm{C}\right.$ ) containing $0.4 \mathrm{mM}$ phenylmethylsulfonyl fluoride (PMSF; Merck), $1 \mathrm{mM}$ ethylene glycol-bis(B-aminoethyl ether) N,N,N'-tetraacetic acid (EGTA; Merck) and $1 \mathrm{mM}$ ethylenedinitrilotetraacetic acid disodium salt (EDTA; Merck) in a concentration of $3 \times 10^{7}$ cells $/ \mathrm{ml}$. The cells were then homogenized with 10 strokes of a tight fitting glass pestle (Braun, Melsungen/Germany) using a potter $S$ homogenizer (Braun). The homogenate was then centrifuged at $100,000 \mathrm{~g}$ for $1 \mathrm{~h}$. The resulting pellet fraction was extracted with $1 \%$ Triton X-100 (Janssen chimica, Geel, Belgium) for $1 \mathrm{~h}$, recentrifuged at $100,000 \mathrm{~g}$ and separated into a pellet and supernatant fraction. Aliquots of these cell fractions were taken, dissolved by boiling in SDS-sample buffer and used for gel electrophoresis.

\section{Gel electrophoresis and immunoblotting}

The procedure for gel electrophoresis and immunoblotting was performed as described before [4]. After blotting to nitrocellulose membranes (BA 85, Schleicher and Schüll, Dassel/Germany), the filter was blocked by incubation in $3 \%$ BSA (Sigma) and $0.1 \%$ Tween 20 (Janssen chimica, Geel/Belgium) in PBS for $1 \mathrm{~h}$ at room temperature with hybridoma supernatant or rabbit antiserum. All supernatants and antisera were diluted in $5 \%$ non-fat dry milk and $0.1 \%$ Tween 20 in PBS. For detection of antibody binding either the alkaline phosphatase technique or the chemiluminescence method were applied, as described before [4].

\section{Immunoprecipitation}

Immunoprecipitation analyses were essentially performed as described before [4]. The $100,000 \mathrm{~g}$ supernatant of a $1 \%$ Triton X-100 extract of total cell homogenates was used. Immunocomplexes of the NSP-gene encoded proteins with RNL-4, POL-8 or with a mixture of MON $160-162$ were formed by incubation overnight at $4^{\circ} \mathrm{C}$ in immunoprecipitation buffer containing $20 \mathrm{mM}$ Tris- $\mathrm{HCl} \mathrm{pH} 8.0,1 \mathrm{mM}$ PMSF, 12.5 $\mu \mathrm{g} / \mathrm{ml}$ leupeptin (Sigma), $116 \mu \mathrm{g} / \mathrm{ml}$ aprotinin (Sigma) and $140 \mathrm{mM} \mathrm{NaCl}$ (Merck), followed by an incubation with $2 \mu \mathrm{l}$ rabbit anti-mouse $\operatorname{Ig}$ (DAKO A/S) for $2 \mathrm{~h}$. Thereafter, $100 \mu$ Protein A-Sepharose CL-4B $(30 \mathrm{mg} / \mathrm{ml}$; Pharmacia, Uppsala/Sweden) was added for $3 \mathrm{~h}$ at $4^{\circ} \mathrm{C}$. The immunocomplexes formed were washed 5 times by centrifugation at $13,000 \mathrm{~g}$ for $2 \mathrm{~min}$. with immunoprecipitation buffer and were subsequently diluted in SDS-sample buffer, boiled for 5 min., size fractionated on SDS-containing polyacrylamide gels and immunoblotted. NSPS were detected using MON 160-162, POL-8 or RNL-4 and visualised by the alkaline phosphatase reaction (see above). As controls RKSE 60, a mab directed to cytokeratin 10 and K5, a rabbit polyclonal serum to desmin, were used. Both proteins are not present in the cell lines used for the immunoprecipitation. 


\section{RESULTS}

\section{Characterization of RNL-4}

The specificity of mab RNL-4 (IgGl subtype) for the amino-terminal amino acid sequence of NSP-C was established on basis of ELISA with the synthetic peptide used for immunization. Furthermore RNL-4 reacts with the bacterially expressed hybrid protein $B-G a l-N S P-C$ in ELISA and is negative for $B-G a l$ alone (data not shown). An identical reactivity pattern was seen with the polyclonal antibody POL-8. Western blot analysis using hybrid proteins of B-Gal or GST with the different NSPs revealed that RNL-4 recognizes B-Gal-NSP-C (Fig. 1, lane 1) and GST-NSP-C (Fig. 1, lane 9), whereas no reaction was observed with B-Gal alone (Fig. 1, lane 2), B-Gal-NSP-A (Fig. 1, lane 5) and B-Gal-NSP-B (Fig. 1, lane 6). POL-8 reactivity confirms the identity of B-Gal-NSP-C (Fig. 1, lane 3) and GST-NSP-C (Fig. 1, lane 10), while this reagent was negative with B-Gal (Fig. 1, lane 4). Similarly, the mabs MON 160-162 were used to identify B-Gal-NSP-A (Fig. 1, lane 7) and B-Gal NSP-B (Fig. 1, lane 8) hybrid proteins. As shown before [6], MON 160-162 do not recognize NSP-B, but are able to react with B-Gal-NSP-B hybrid protein. This results from the fact that in plasmid pUR NSP-B, the open reading frame for NSP-B is fused to that of Bgalactosidase via polylinker and 5'-upstream sequences of the authentic initiation codon in the NSP-B transcript; these latter sequences are not translated in vivo, but are identical to a part of the open reading frame for NSP-A.

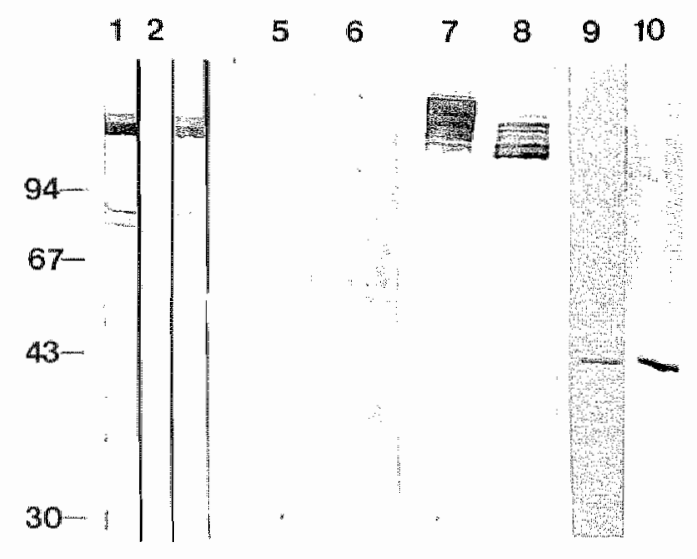

Figure 1. Immunoblotting analysis of RNL-4 (lanes $1,2,5-9$ ) and POL-8 (lanes $3,4,10$ ) applied to bacterially expressed proteins. In lanes 1,3: B-Gal-NSP-C; lanes 2,4: B-Gal; lanes 5,7: B-Gal-NSP$A$; lanes 6,8: B-Gal-NSP-B; lanes 9,10: GST-NSP-C. Lanes 7 and 8 the first incubations with RNL-4 were followed by a second incubation with the mixture of MON 160-162. Antibody binding was detected by the alkalline phosphatase method. Molecular weight markers are indicated.

To further confirm the specificity of RNL-4 for NSP-C, COS- 1 cells, transfected with pSVL-NSP-B and PSVL-NSP-C were used for immunofluorescence analyses. COS-1 cells, transfected with NSP-C cDNA constructs and incubated with RNL-4, showed a very strong perinuclear and a lace-like cytoplasmic staining pattern, characleristic for the ER (Fig. 2a,2b). A remarkably strong immunoreactivity was often seen in the extensions of these cells. An identical staining pattern is observed with POL-8 (Fig. 2c). COS-1 cells transfected with the NSP-B construct were negative for RNL-4 (Fig. $2 \mathrm{~d}$ ), but strongly positive for RNL-2 (Fig. 2e). When the distribution of NSP-C is compared to that of NSP-B, similar patterns are seen. 


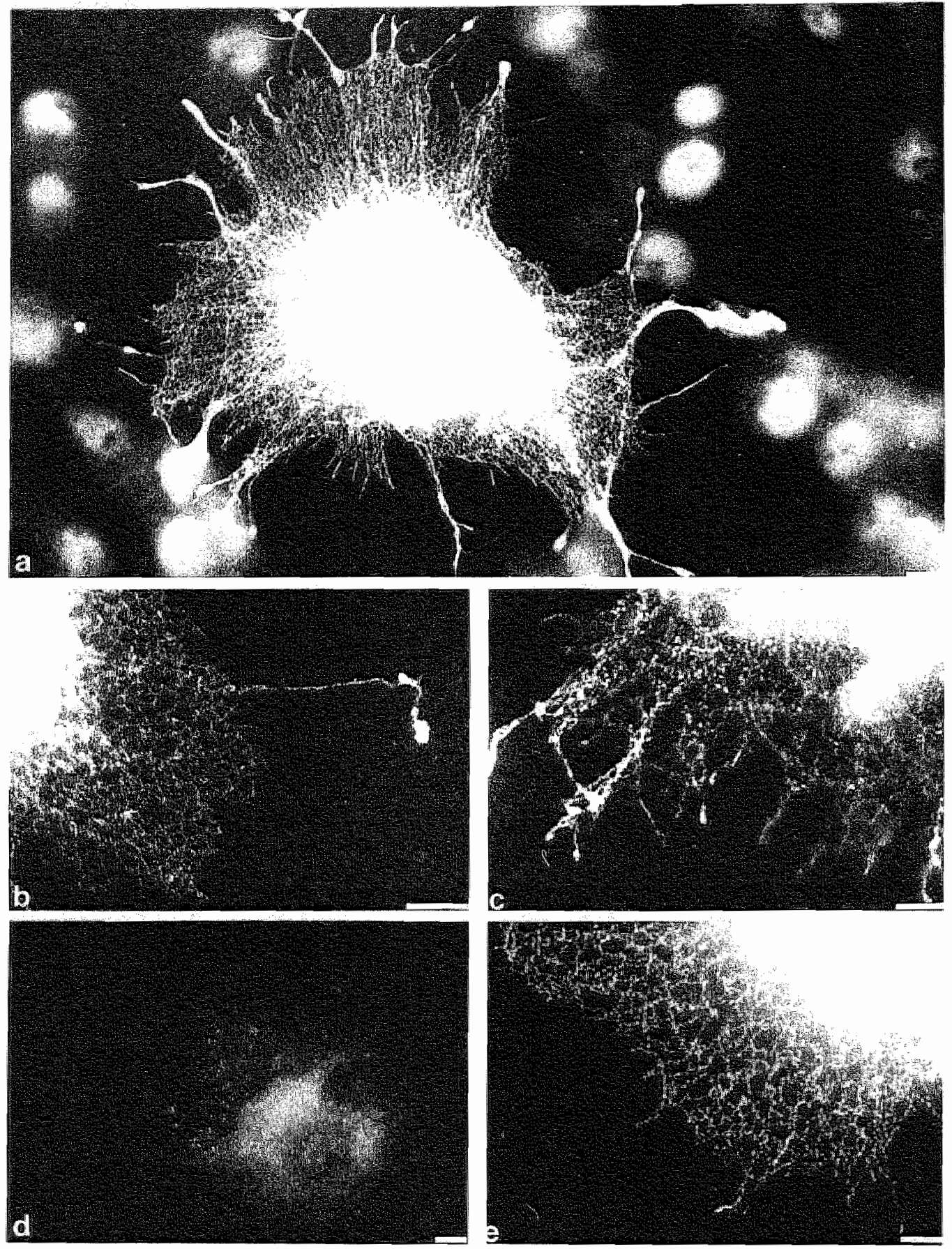

Figure 2. Immunocytochenical localization of NSP-C and NSP-B to the endoplasmic reticulum of COS-1 cells transfected with pSVL-NSP-C CDNA (a,b,c) or with pSVL-NSP-B aDNA (d,e). Cells were stained for NSP-C with RNL-4 $(a, b, d)$ or with POL-8 (c) and for NSP-B with RNL2 (e). Bar: 5 $\mu \mathrm{m}$. 


\section{Differential expression patterns of NSP-C and NSP-A in normal human tissues}

The immunoreactivity patterns of NSP-C and NSP-A antisera with different types of normal human tissues are summarized in Table 1 and depicted in Fig. 3. In general, POL-8 showed less intense immunoreactivity patterns as compared to RNL-4 when used for immunoperoxidase procedures. Chromogranin A and synaptophysin were used for the identification of neural and/or NE cells. On basis of the staining patterns we conclude that NSP-C occurs in a subset of tissues of neuroectodermal origin, i.e. central and peripheral nerve tissue, neurohypophysis and adrenal medulla, as well as in a very restricted number of NE tissues, i.e. the adenohypophysis, pars intermedia and sporadic NE cells in the lung. In the central nervous system a weak, diffuse staining reaction was found in neurons of the granular and molecular layer of the cerebellar cortex, while glia cells, cerebellar medulla and Purkinje cells (Fig. 3a) were negative for NSP-C. NSP-A expression was observed in axons of the molecular cell layer, while a weak cytoplasmic reaction was present in the granular cell layer, in which the Golgi cells stained more pronounced for NSP-A. In cell bodies, axons and dendrites of Purkinje cells, a strong expression of NSP-A was observed (Fig. 3b), as shown before $[2,6]$. Furthermore strong staining for both NSP-A and NSP-C was observed in neurons and neuropil of the cerebral neocortex (Fig. 3 c,d). In pituitary, a strong reactivity was detected in the axons of the neurohypophysis with RNL-4 (Fig. 3e) and POL-8. Also strong NSP-A expression was found in the neurohypophysis (Fig. 3f). NSP.C expression was seen in a fraction of the hormone producing cells in the adenohypophysis, lacated mainly in the central part of the gland (Fig. $3 \mathrm{~g}$ ) and in epithelium cells of cysts of the pars intermedia (Fig. 3h). NSP-A expression could be seen throughout the whole adenohypophysis in a larger fraction of cells as compared to NSP.C (Fig. 3i). Synaptophysin was found in all neural and NE cell types of the pituitary. Chromogranin A posilivity was observed in a fraction of the NE cells of the adenohypophysis, in sporadic cells of the pars intermedia and could not be detected in the neurohypophysis. In the adrenal gland NSP-C (Fig. 3j) and NSP-A (Fig. 3k) could be observed in the pheochromocytes of the medulla, but the number of cells expressing NSP-C was less than those positive for NSP-A. Synaptophysin was found in comparable cell numbers as NSP-A, although for NSP-A heterogeneous expression levels were found, while also chromogranin $A$ was found in the pheochromocytes. The adrenal cortical cells were negative for NSP-C and NSP-A, but NSP-A was found in dendritic cells, which were negative for chromogranin A, synaptophysin and $S-100$ but positive for CD68. A strong staining is seen for NSP-C in peripheral nerves and ganglia of various tissues (Fig. $31, n$ ). These nerve cells were also stained by the polyclonal antiserum to synaptophysin (Fig. $3 \mathrm{~m}$ ), but the polyclonal and mabs to NSP.A showed a more restricted reactivity pattern with peripheral nerves. Furthermore, NSP-C and NSP-A were found to be expressed in a smaller subset of the NE cells present in the bronchus (Fig. 3 o,p) as compared to the number of NE cells found to be positive with the synaptophysin antibody, which had however an identical appearance. A strong reaction of the NSP-A antibodies, both monoclonal and polyclonal, was seen in the alveolar macrophages. Also in other tissues, for instance in the gastro-intestinal tract, macrophage-like cells, positive for CD68, were reactive for all the NSP-A antibodies MON 160-162, RNL-2, RNL-3 and POL-1. For RNL-2 and RNL-3 this crossreactivity was reported before [27]. Also, the dendrilic Langerhans cells in skin contain NSP-A. All these cells were negalive for NSP-C. 

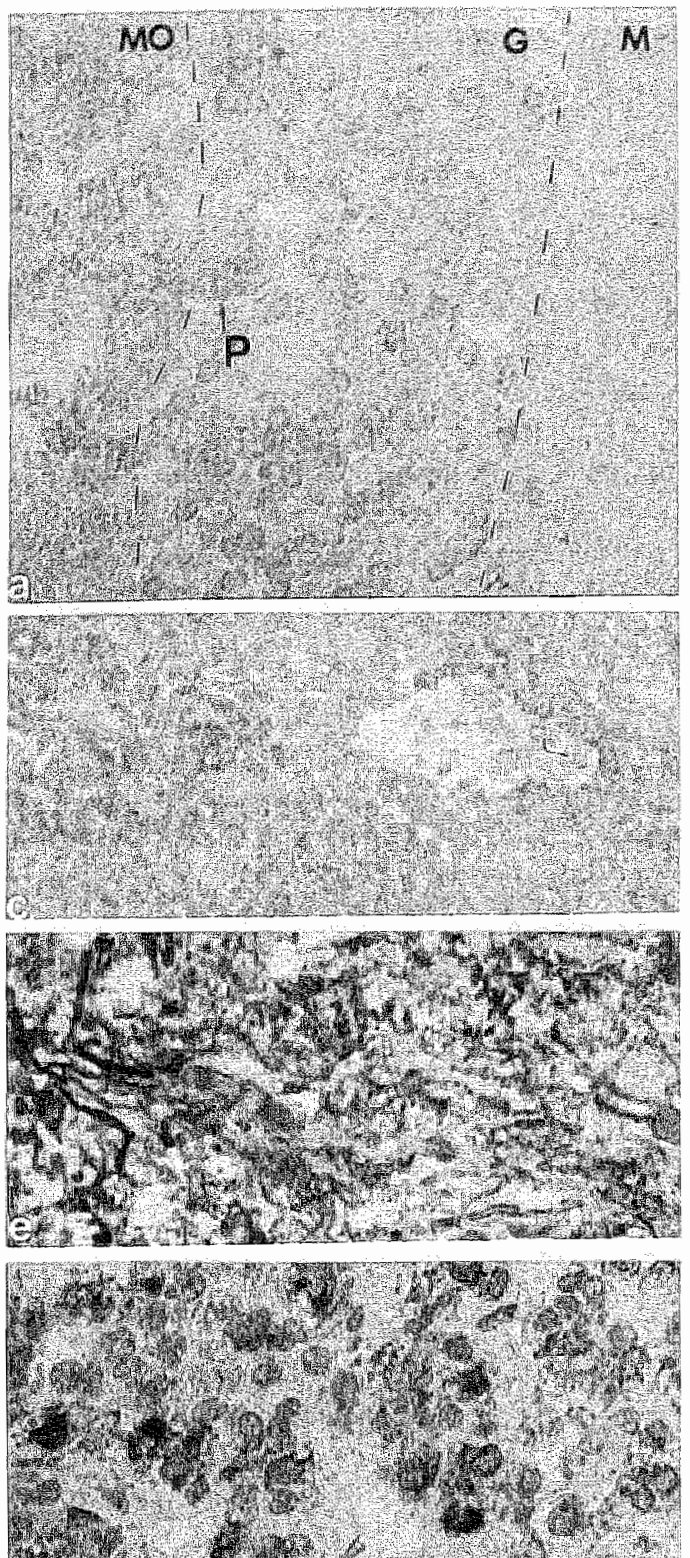

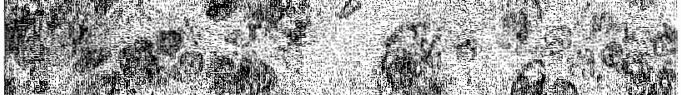
H.

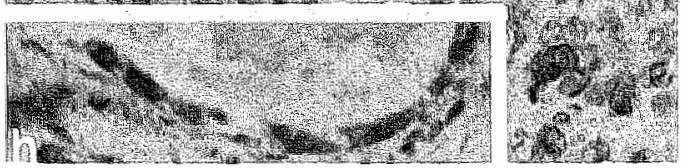

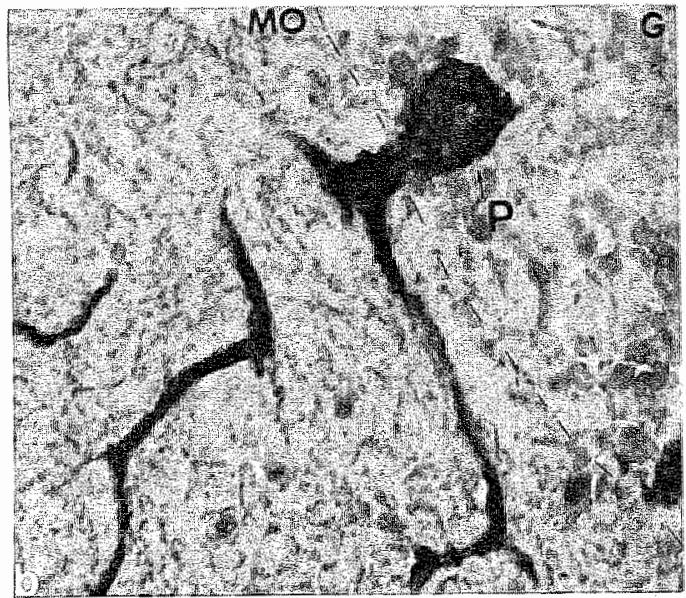

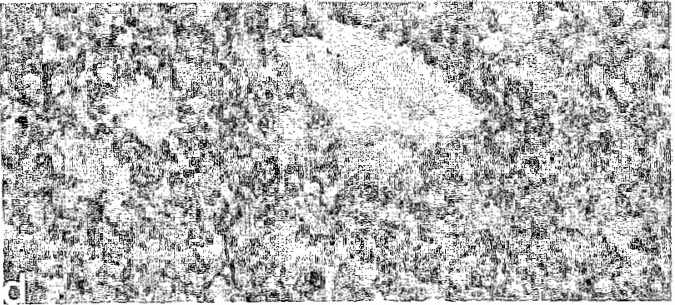

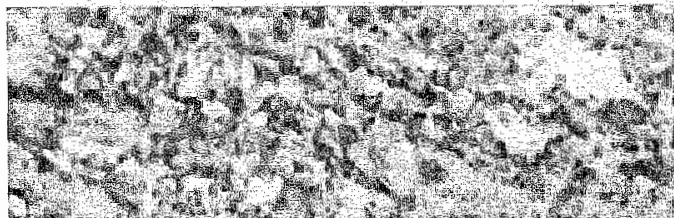

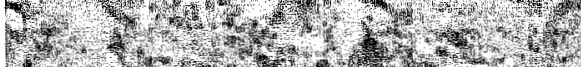

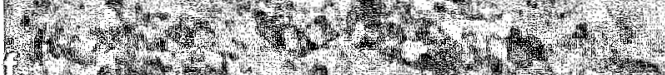

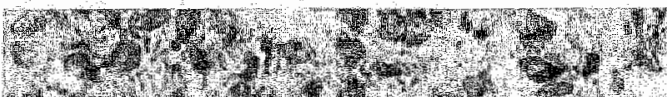

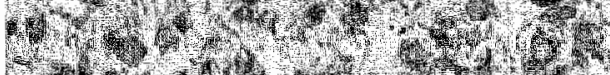

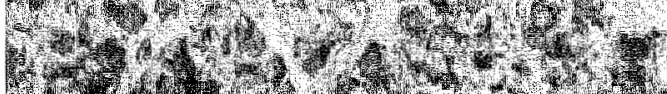

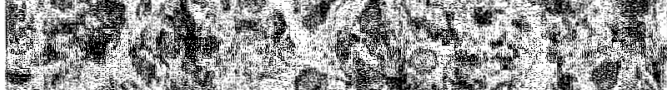

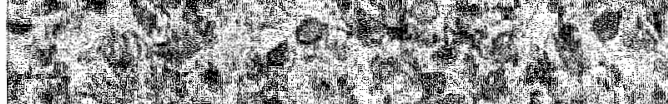
MVI 36)

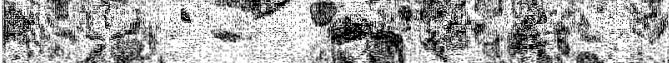

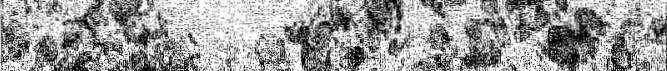

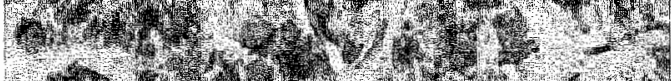

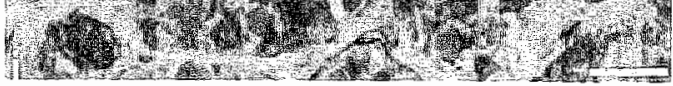

Figure 3. Immunoperoxidase staining patterns of NSP-C as detected by RNL-4 $\left(\mathrm{a}, \mathrm{c}, \mathrm{e}, \mathrm{g}_{n} \mathrm{~h}, \mathrm{j}, \mathrm{l}, \mathrm{n}, \mathrm{o}\right)$ compared to NSP-A staining by MON 160-162 $(\mathrm{b}, \mathrm{d}, \mathrm{f}, \mathrm{i}, \mathrm{k}, \mathrm{p})$ or to staining for synaptophysin (m) in normal human tissues. (a,b) cerebellum with granular layer $(G)$, molecular layer (MO), medulla (M) 
NSP-C could not be detected in NE cells of other tissues, which were however positive for NSP-A, such as the islets cells of the pancreas, calcitonin producing cells of the thyroid, parenchymal cells of the parathyroid or NE cells in stomach and small intestine. When NSP-A immunoreactivity in the lower gastro-intestinal tract was compared to that of chromogranin A and synaptophysin it became evident that NSP-A is expressed in a subset of the NE cells in stomach and small intestine, and is absent in such cells from colon.
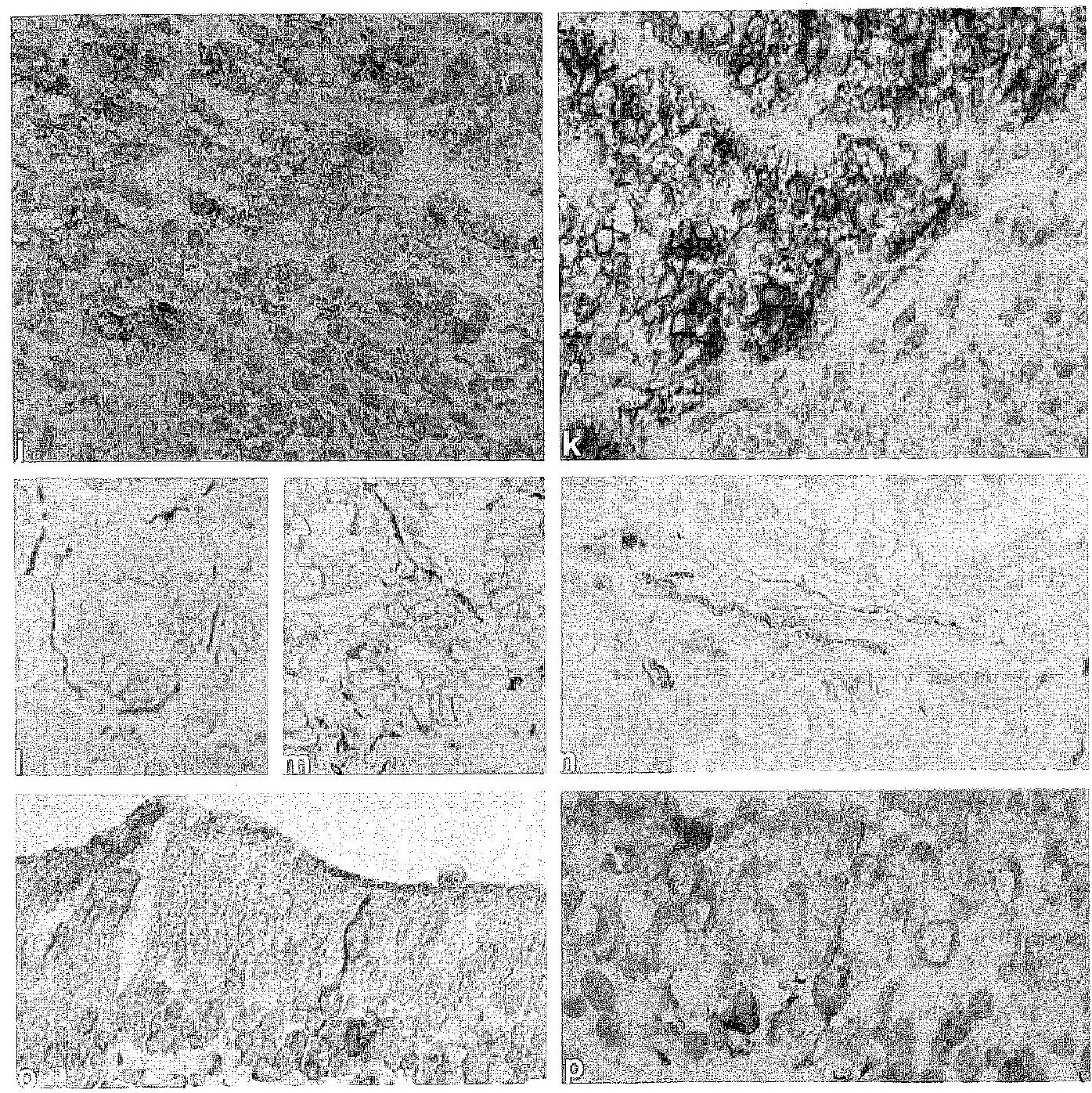

and Purkinje cell (P) indicated (c,d) cerebral cortex, (e,f) neurohypophysis, (g,i) adenohypophysis, (h) pars intermedia, $(j, k)$ adrenal gland with medulla $(M)$ and cortex $(C)$ indicated, $(1, m)$ peripheral nerwes in small intestine, (n) peripheral nerves in stomach, $(o, p)$ bronchus epithelium. Bar: $20 \mu m$ in $(a-0)$; $12.5 \mu \mathrm{m}$ in $(\mathrm{p})$. 
No immunoreactivity for NSP-C was observed in epithella of the skin, pulmonary tract, the gastro-intestinal tract, the urogenital system, nor in striated muscle. An unexpected immunoreactivity of RNL-4, but not of POL-8, was observed with smooth muscle cells. Also myoepithelial cells were shown to be positive with RNL-4. When tested on immunoblots of tissues (i.e. intestine, prostate, uterus) this protein comigrated with a constituent, immunoreactive with anti- $\alpha s m-1$, an antibody recognizing $\alpha$-smooth muscle actin (data not shown).

Table 1.

Tissue distribution of NSP-C as compared to NSP-A, synaptophysin and chromogranin $A$

\section{TISSUE TYPE}

\section{Brain}

cerebellar cortex molecular cell layer granular cell layer Purkinje cells gliall cells cerebellar medulla glial cells cerebral cortex peripheral nerves ganglion cells piltuitary adenohypophysis neurohypophysis pars intermedia adrenal gland medulla

pheochromocytes cortex cortical cells dendritic cells nerves

thymoid follicular cells Cocalls partathyroid congue squanous epithelium nerves oesophagus stratified epithelium lung bronchial ep ithelium NE cells glands myoepitheliun alveolar epithelium macrophages nerves

NSP-C NSP-A Syn CgA

\begin{tabular}{|c|c|c|c|}
\hline & & $+\infty$ & \\
\hline$\pm^{a t}$ & + & +6 & \\
\hline \pm & $+1-$ & $++^{b}$ & \\
\hline - & + & $D^{b}$ & \\
\hline - & - & $b$ & $c$ \\
\hline - & $+1 \%$ & b & ${ }_{-}^{c}$ \\
\hline$\infty$ & - & $-b$ & ${ }^{c}$ \\
\hline+ & + & $+b$ & $+c$ \\
\hline+ & $+1-$ & + & - \\
\hline+ & $+1-$ & + & - \\
\hline$+/ \pi$ & + & + & $41-$ \\
\hline+ & + & + & - \\
\hline$+p$ & + & + & $+1-$ \\
\hline
\end{tabular}

$\begin{array}{cccc}+1- & + & + & +1- \\ - & + & - & - \\ + & +1- & + & - \\ - & + & -d & +d \\ - & + & +^{d} & +d\end{array}$


Table 1.

Tissue distribution of NSP-C as compared to NSP-A, synaprophysin and chromogranin $A$

\begin{tabular}{|c|c|c|c|c|}
\hline TISSUE TYPE & $\mathrm{NSP}-\mathrm{C}$ & NSP-A & Syn & $\mathrm{CgA}$ \\
\hline \multicolumn{5}{|l|}{ stomach } \\
\hline epithelium & - & - & - & - \\
\hline NE cells & - & $+1-$ & + & + \\
\hline nerves & + & - & + & - \\
\hline \multicolumn{5}{|l|}{ small intestine } \\
\hline epithelium & - & - & - & - \\
\hline NE cells & - & $+1-$ & + & + \\
\hline nerves & + & - & + & - \\
\hline \multicolumn{5}{|l|}{ colon } \\
\hline epithelium & - & - & - & $\infty$ \\
\hline NE cells & - & $+1-$ & + & + \\
\hline nerves & + & - & + & - \\
\hline \multicolumn{5}{|l|}{ pancreas } \\
\hline islet cells & - & + & $+d$ & $+t^{d}$ \\
\hline ducts and acini & - & - & -4 & d \\
\hline hepatocytes & - & - & & \\
\hline Kuppfer cells & - & - & & \\
\hline bile duct & - & - & & \\
\hline macrophages & - & + & & \\
\hline kidney & - & - & $-\mathrm{d}$ & $-\infty, 0$ \\
\hline liver & - & - & $-d$ & $-\mathrm{e}$ \\
\hline \multicolumn{5}{|l|}{ urinary bladder } \\
\hline transitional epithelium & - & - & & \\
\hline smooth muscle & $+t^{f}$ & - & & \\
\hline \multicolumn{5}{|l|}{ prostate } \\
\hline glandular epithelium & - & - & & - \\
\hline smooth muscle & $t^{f}$ & - & & \\
\hline ovary & - & - & & $-e$ \\
\hline \multicolumn{5}{|l|}{ mammary gland } \\
\hline myoepithelium & $+{ }^{r}$ & - & & \\
\hline \multicolumn{5}{|l|}{ cervix } \\
\hline ectocervix & - & - & & 2 \\
\hline skin & & & $-\mathrm{c}$ & -0 \\
\hline epidermis & - & - & & \\
\hline Langerhans cells & - & + & & \\
\hline nerves & + & - & & \\
\hline smooth muscle & +1 & - & & \\
\hline myocard & - & - & $b^{b}$ & \\
\hline skeletal muscle & - & - & b & $-b$ \\
\hline \multicolumn{5}{|l|}{ blood vessels } \\
\hline endothelium & - & - & & \\
\hline smooth muscle & $+r$ & - & & \\
\hline
\end{tabular}

a. -, negative; \pm , weak diffuse reaction; +1 , partly positive reaction;

+ , strong positive reaction

b: data extracted from Navone et al., [35]; results of rat tissue, using monoclonal antibodies and rabbit antiserum against p38 (synaptophysin) [36].

c: data extracted from Nolan et al., [37], results of bovine tissue, using rabbit antiserum against chromogranin A [37].

: data extracted from Wiedenmann and Huttner $[23$ ]; results of human tissue, using monoclonal antibody SY38 [23] and monoclonal antibody LK.2H 10 [38].

e. positive reaction observed in solitary neuroendocrine cells [22].

: positive reaction only with RNL 4 and not with POL-8. 


\section{Differential expression patterns of NSP-A and NSP-C in human tumor cell lines}

NSP-A and NSP-C expression was investigated in several lung cancer cell lines, two neuroblastoma cell lines, a colon cancer cell line with NE features and a bladder cancer cell line. No specific staining patterns could be detected in the cell lines with POL 8, irrespectively of the applied fixation procedure. Therefore, our immunofluorescence data for NSP-C are obtained with RNL-4. Results of the immunofluorescence studies are summarized in Table 2 and depicted in Figs. 4-7.

\section{Table 2.}

Differential expression of NSP-C and NSP-A in human tumor cell lines

\begin{tabular}{|c|c|c|c|c|c|}
\hline TYPE & cell line & NSP-C & $\begin{array}{l}\text { NSP-C } \\
\text { MRNA }\end{array}$ & NSP-A & $\begin{array}{l}\text { NSP-A } \\
\text { mRNA }\end{array}$ \\
\hline \multirow[t]{4}{*}{$S C L C-V$} & NCI-H82 & $-a^{a}$ & $+1{ }^{b}$ & $+t$ & + \\
\hline & GLC-1 & + & ++ & - & \pm \\
\hline & SCLC-2 $1 \mathrm{H}$ & + & +4 & ++ & + \\
\hline & SCLC-16HV & - & - & + & + \\
\hline \multirow[t]{4}{*}{$\mathrm{SCLC}-\mathrm{C}$} & NCI-H69 & - & nd & ++ & nd \\
\hline & $\mathrm{NCI}-\mathrm{H} 249$ & + & + & - & - \\
\hline & GLC-1M13 & \pm & \pm & - & - \\
\hline & $\$ \mathrm{CLC}-16 \mathrm{HC}$ & $+1-$ & + & + & + \\
\hline \multirow[t]{3}{*}{ non-SCLC } & NCI-H125 & - & - & - & - \\
\hline & MR-65 & - & nd & - & nd \\
\hline & LCLC-103H & - & nd & - & nd \\
\hline \multirow[t]{3}{*}{ non-SCLC-NE } & NCI-H460 & - & - & $+t$ & $+t^{c}$ \\
\hline & NCI-H810 & + & nd & ++ & nd \\
\hline & $\mathrm{NCI}-\mathrm{H} 1155$ & + & $+1-c$ & ++ & $++c$ \\
\hline \multirow[t]{2}{*}{ neuroblasttoma } & SK-N-SH & ++ & $+t$ & $+1-$ & $+t$ \\
\hline & CHP-212 & - & nd & + & nd \\
\hline colom carcinoma & $\mathrm{NCI}-\mathrm{H} 716$ & - & nd & + & nd \\
\hline bladder carcinoma & $T 24$ & - & nd & - & nd \\
\hline
\end{tabular}

\footnotetext{
"For NSP protein expression: -, no reaction un any cells; \pm , weak staining in some cells; $+1-$, reactivity in $<25 \%$ of the cells; + , reactivity in $25-90 \%$ of the cells; ++ , reactivity in virtually all cells.

b: For NSP mRNA levels: - negative, +/- non-conclusive, \pm detectable, + and ++ increasingly higher levels of NSP mRNA expression.

: Senden et al., NSP-reticulons as independent markers for non-small cell lung cancer with neuroendocrine differentiation, submitted.
}

NSP-C was clearly detected in 4 out of 8 SCLC cell lines (Fig. 4), while GLC-1M13 showed weak positivity in only a small number of cells. NSP-C was not found in typical non-SCLC cell lines, while 2 out of 3 non-SCLC-NE cell lines were positive. Of these lung cancer cell lines two SCLC cell lines showed simultaneous expression of NSP-A and NSP-C (Fig. 5 a,b), which was also observed in the two non-SCLC-NE cell lines (Fig. $5 \mathrm{c}-\mathrm{f}$ ). In these cells coexpression of NSP-A and NSP-C at the individual cell level could be observed, although the number of NSP-C positive cells was less than the NSP-A positive cells. Both NSP-A and NSP-C antibodies showed similar 
staining patterns in these cell lines 1. an association whthe ER. In some of these cell lines longitudinal extensions of the cells were strongly positive for NSPS (Fig. 5e), especially in their growth cones. These growth cones were shown to contain ER by IID8 immunostaining for $\mathrm{Ca}^{2+}$-ATPase SERCA2b (Fig. 6). Occasionally, in adherent cells, including those that did not showing an ER staining pattern, RNL-4 reacted with short membranous protrusions (data not shown). Double immunofluorescence studies showed a partial overlap of both NSPS at the single cell level. In some instances, NSP. $C$ antibody reactivity was mainly restricted to long extensions of the cell, which were not stained with the NSP-A antibodies.
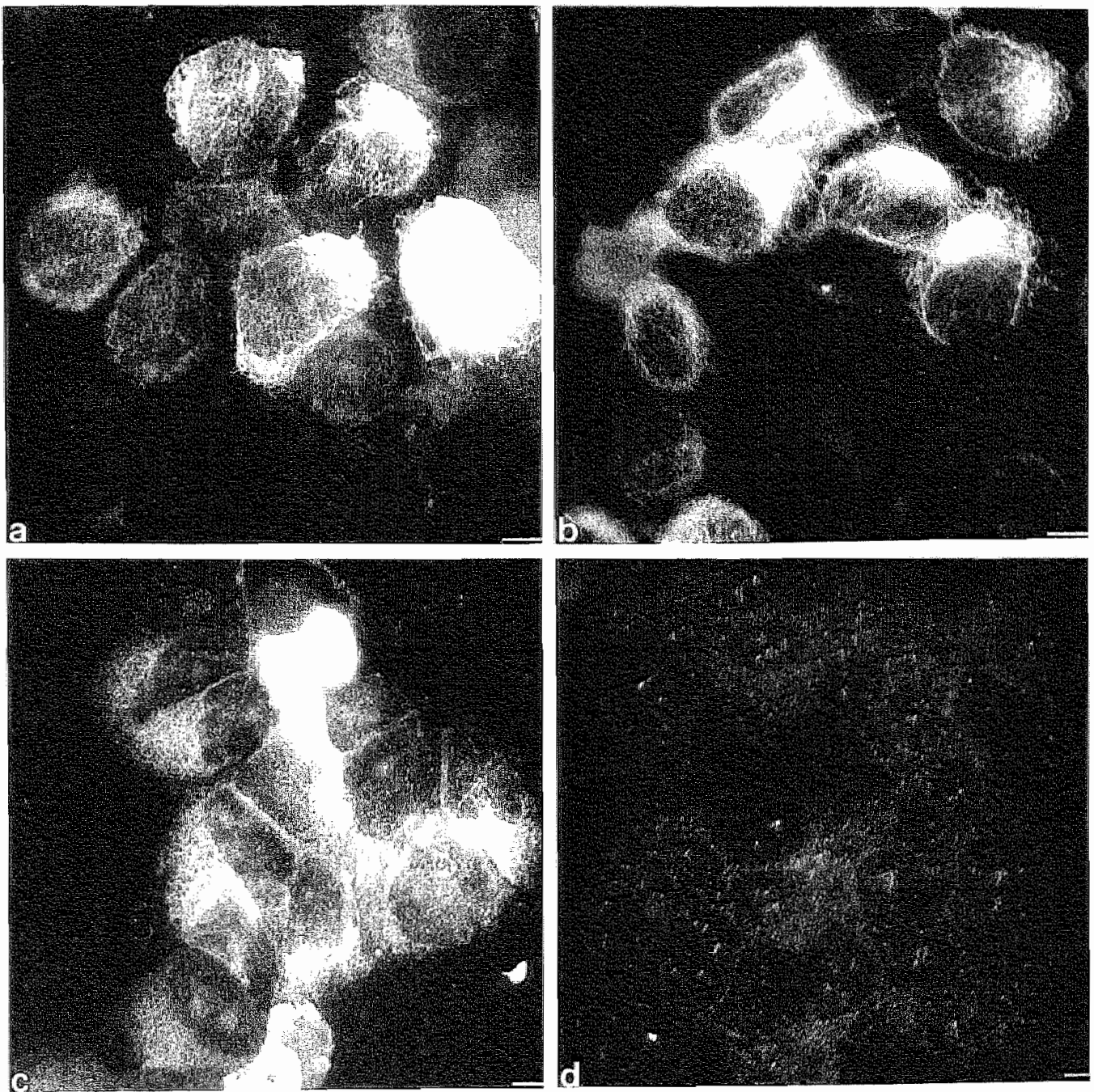

Figure 4. Immunocytochemical localization of NSP-C, as detected with RNL-4, to the endoplasmic reticulum of the lung cancer cell lines GLC-1 (a), NCI-H249 (b) and SCLC $16 H C$ (c). No reaction is seen in cell line SCLC-16HV (d). Bar: $5 \mu \mathrm{m}$. 
Next to cell cultures expressing only NSP-C, three SCLC cell lines and ane nonSCLC-NE cell line showed expression of onlly NSP-A. These immunocytochemical data are in accord with results of Northern blotting studies (Table II; see ref. 3). Of the two neuroblastoma cell lines studied, SK-N-SH showed an expression of both NSPC (Fig. 7a) and NSP-A (Fig. 7b), with the number of cells expressing NSP-A being less than compared to NSP-C positive cells. Also, in this cell type an association with the ER is observed, combined with a strong immunostaining in the neuritic processes of the cells (Fig. 7e). In the other neuroblastoma cell line CHP-212, NSP-C could not be detected (Fig. 7c), while NSP-A expression was observed in a subpopulation of the cells (Fig. 7d) also showing neurite-like extensions (Fig. 71 ).

Furthermore, in the colon cancer cell line NCI-H716, known to contain NE features $[15,28]$ only NSP-A and no NSP-C expression was observed. The bladder cancer cell line T24 was negative for the NSP-A and NSP-C antibodies.
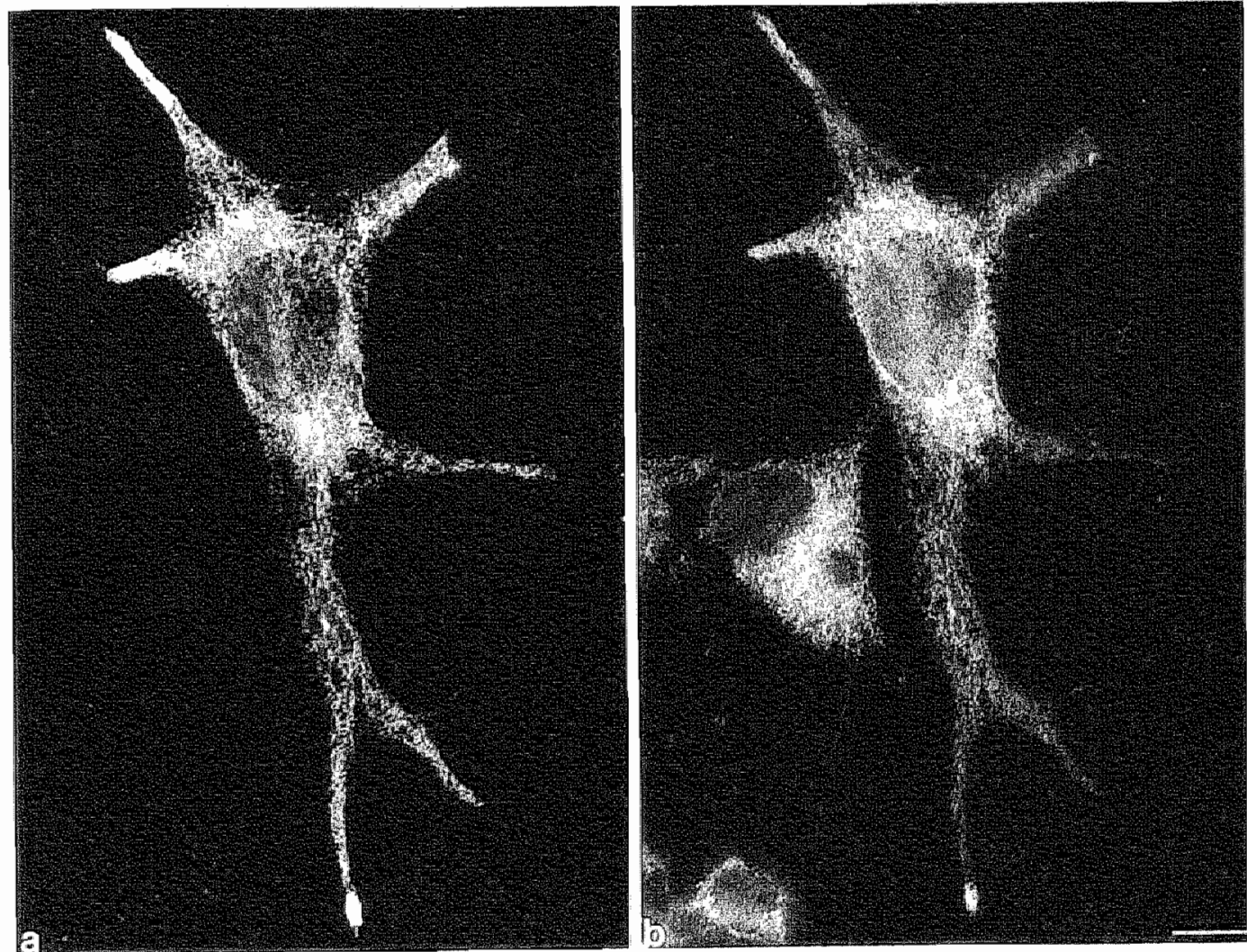

Figure 6. Double immunofluorescence micrographs of NCH H524 adherent SCLC cells showing colocalization of the endoplasmic reticulum marker SERCA2b (a) and NSP-reticulons, ass detected by POL-1 (b). Note the strong immunoreactivity of both antibodies with endoplasmic reticulum in the cellular extensions and growht cones. Bar: 10 pm. 

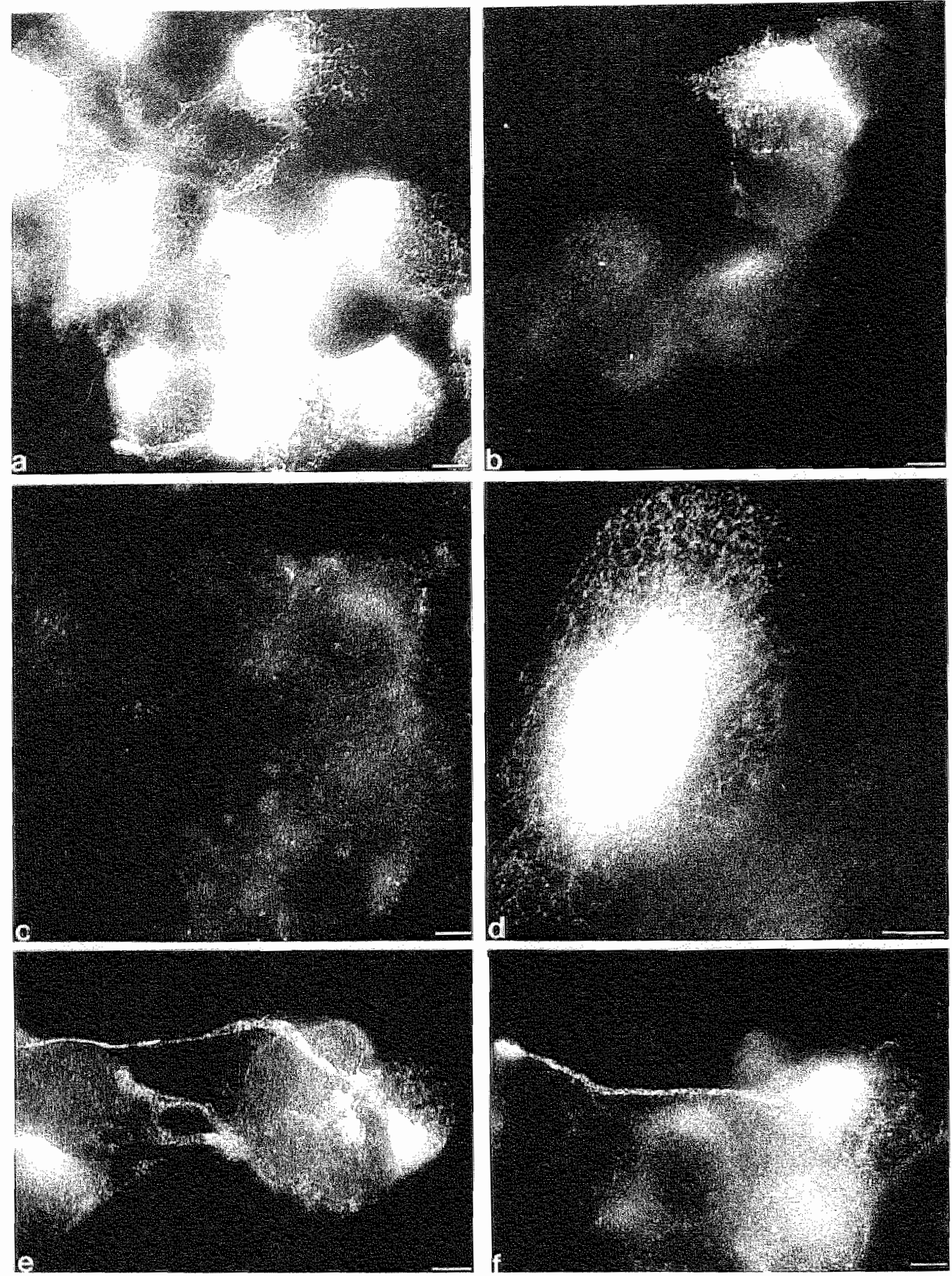

Figure 7 . Immunocy tochemical localization of NSP-C and NSP-A in the endoplasmic reticulum of neuroblastoma call limes SK-N-SH $(a, b, e)$ and CHP-212 $(c, d, t)$. Cells were stained with RNL-4 $(a, c, e)$ or with the mixture of MON $160 \mathrm{~m} 162(\mathrm{~b}, \mathrm{c}, \mathrm{f})$. Note in $(\mathrm{e}, \mathrm{f})$ the strong immunoreactivity in neuritic outgrowths of the cells. Bar: $5 \mu \mathrm{m}$. 
To confirm the immunacytochemical results for NSP-A and NSP-C in these cell lines, immunoblotting studies were performed. In the Triton X-100 extracts of SCLC cell line GLC-1, a protein band for NSP-C at $23 \mathrm{kDa}$ could be detected with POL-8 (Fig. 8a, lane 1) and RNL-4 (Fig. 8a, lane 2). Also a NSP-C protein band was detected with RNL-4 in the SCLC cell line NCI-H249 (Fig. 8a, lane 4). In both cell lines no NSP-A was observed. No NSP-C could be detected in SCLC-16HV (Fig. 8a, lane 3), while NSP-A was present after detection with MON 160-162 (Fig. 8a, lane 3). In the cell line SCLC-21H both NSP-A and NSP-C were observed (Fig. 8a, lane 5). The distinct NSP-C protein band at $23 \mathrm{kDa}$ was often accompanied by diffuse tailing at the lower side. The immunoblotting results for celll lines GLC-1 and SCLC-21H were confirmed by immunoprecipitation studies (Fig. 8b). Immunoblot analyses of Triton X-100 extracts of the neuroblastoma cell lines showed expression of NSP-A and a very strong expression of NSP-C in the cell. line SK-N-SH (Fig. 8c, lane 1), whereas in CHP-212 only NSP-A expression could be detected (Fig. 8c, lane 2). In the colon carcinoma cell line NCI-H716 only NSP-A expression was observed (Fig. 8c, lane 3). In several cell lines, also those shown not to contain NSP-C, an additional reaction of RNL-4 was seen with a protein band in the $45 \mathrm{kDa}$ region. This protein was not detected by $\mathrm{POL}$ 8.
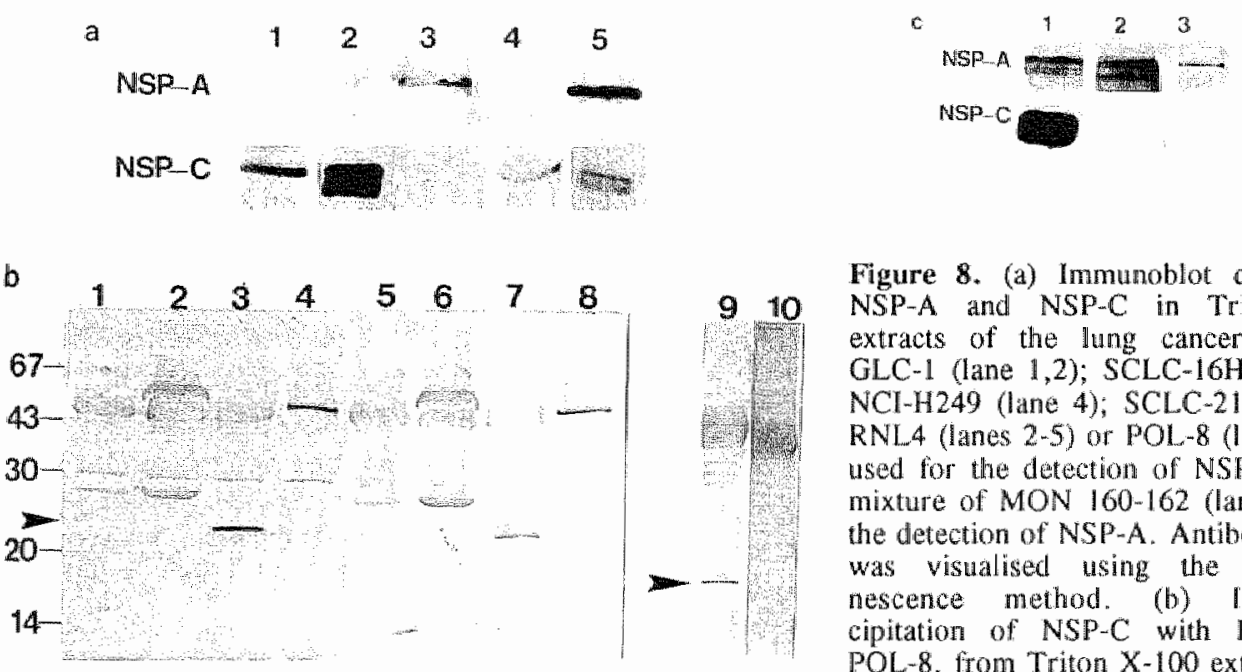

b

Figure 8. (a) Immunoblot detection of NSP-A and NSP-C in Triton X-100 extracts of the llung cancer cell lines GLC-1 (lane 1,2); SCLC-16HV (lane 3); NCI-H249 (lane 4); SCLC-21H (lane 5). RNL4 (Ianes 2-5) or POL-8 (tane 1) were used for the detection of NSP-C and the mixture of MON 160-162 (lanes 2-5) for the datection of NSP.A. Antibodly binding was visualised using the chemiluminescence method. (b) Immunoprecipitation of NSP-C with RNL-4 and POL -8 , from Triton X-100 extracts of the lung cancer cell lines SCLC-21H (lanes

$1-4,9,10)$ and GLC-1 (lanes 5-8). NSP-C was either immunoprecipitated with RNL-4 (lanes 1,5) or with POL-8 (lanes $3,7,9,10$ ), while lanes 2 and 6 contain the monoclonat antibody control RKSE 60 precipitates, and lanes 4 and 8 the polyclonal antiserum control K5 precipitates. Lanes $1-8$ were incubated with RNL-4, lanes 9 with POL-8 and lane 10 with control serum K5. No NSP-C protein bands were obserwed in these control lanes, whille specific bands at the $23 \mathrm{kDa}$ region were seen in the NSP-C precipitates (arrow). Other bands occurring in these lanes are due to interaction of the alkaline phosphatase-conjugated secondary antibody with the mouse or rabbit Ig-subunits, which were present in the immunoprecipitates. Compare for example lanes 9 and 10. Molecular weight markers are indicated. (c) Immunoblot detection of NSP-A and NSP-C in Triton X-100 extracts of the neuroblastoma cell lines SK-N-SH (lane 1) and CHP-212 (lane 2), as well as the nearoendocrine colon carcinoma cell line NCI-H716 (lane 3) with RNL-4 for NSP-C (lanes 1,2) and MON $160-162$ for NSP $-A$ (lanes 1,3 ). 
Subcellular localization of NSP-C in relation to NSP-A

Differential centrifugation experiments performed with cell lines GLC-1, SCLC-21H, NCI-H249, SCLC-16HV, SCLC-16HC, SK-N-SH and CHP-212, were used to define the subcellular localization of NSP-C in relation to NSP-A. It became apparent that NSP-C behaved similarly to NSP-A during the different extraction and centrifugation steps. Extraction with Triton X-100 of $100,000 \mathrm{~g}$ cell pellets could completely solubilize both proteins from these membrane fractions (Fig. 9).

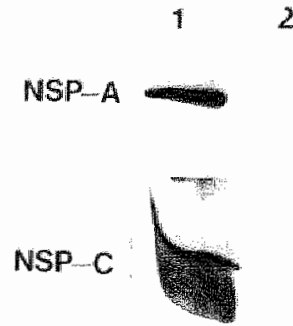

Figure 9. Immunoblot analysis of the distribution of NSP-A and NSP $C$ in cell line SCLC-21H upon cell fractionation and extraction with Triton $X-100$, by MON 160-1.62 and RNL-4, respectively. Lane 1: supernatant after Tritorn $X-100$ extraction of $100,000 \mathrm{~g}$ pellet fraction; lane 2: pellet fraction after Triton X-100 extraction of $100,000 \mathrm{~g}$ pellet fraction.

Earlier studies have indicated that NSP-A polymerizes into large aggregates in NCIH82 and SCLC-21H, while for NCI-H82 a copolymerization of NSP-A and NSP-B was suggested [4]. To investigate whether or not NSP C forms such complexes in association with NSP-A, immunoprecipitation analyses were performed with intact NSP-reticulons of SCLC-21H cells. It was shown that after immunoprecipitation of these complexes with POL-8, NSP-C can be detected in these immunoprecipitates (Fig. 10, lane 1), while no NSP-A was present (Fig. 10, lane 3). In immunoprecipitates formed by incubation with the NSP-A antibody cocktail MON 160-162 no NSP-C (Fig 10, lane 5) could be detected, while staining of the immunoblots with MON 160-162 revealed the presence of NSP-A in these precipitates (Fig. 10, lane 7). These results show that the NSP-A antibody cannot coprecipitate NSP-C, and that vice versa, the NSP-C antiserum cannot coprecipitate NSP-A.

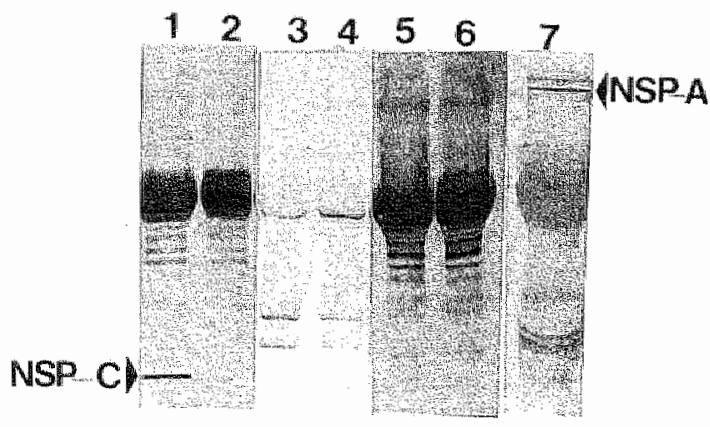

Figure 10. Immunoprecipitation analysis. of native NSP-reticulons of Triton X-100 extracts of SCLC-2IH cells. NSPreticulons were either inmunoprecipitated with POL-8 (lanes 1,3) or with MON 160-162 (lanes 5,7). The presence of NSP-C is visualised by incubation of the blots with POL-8 (lanes 1,2,5,6). NSP-A is detected by incubation with antibodies MON 160-162 (lares 3,4,7). The specific NSP-C band at $23 \mathrm{kDa}$ and the specific NSP.A band at $135 \mathrm{kDa}$, are denoted by arrows. Control incubations are shown in lanes 2,4 for K5 and lane 6 for RKSE 60 . Molecular weight narkers are indicated. 


\section{DISCUSSION}

\section{NSP-C immunoreagents}

The two antibodies to NSP-C, i.e. the rabbit polyclonal antibody POL-8 [5] and the mouse mab RNL-4 are both directed against the amino-terminal end of this protein. Their epitopes are, more precisely, located within the first 20 unique amino-terminal amino acid residues of NSP-C. The remaining 188 amino acid residues are identicall to NSP-A sequences and comprise two large hydrophobic regions [1]. This hydrophobic part leads to a calculated pI of 9.31 for NSP-C, in contrast to the very acidic NSP-A and NSP-B, with a pl of 4.35 and 4.9 , respectively $[1,4]$. The epitope of POL-8 can not be determined more precisely. For RNL-4 our circumstantial data indicate the recognition of an epitope comprising the DST amino acid triplet of the NSP-C amino terminus. As indicated by our immunohistochemical studies. RNL-4 (unlike POL-8) cross-reacts with smooth muscle cells and myoepithelium. Furthermore, immunoblotting of tissues revealed cross-reactivity with a protein band in the $45 \mathrm{kDa}$ molecular weight region which comigrated with $\alpha$-smooth muscle actin. For the production of anti- $\alpha \mathrm{sm}-1$ the decapeptide EEEDSTALVC was used, specifically occurring in smooth muscle actin [25]. When comparing this sequence to that of the NSP-C specific peptide MQATADSTKMDCVWSNWKSQ, the common triplet is recognized in both sequences and it is therefore likely that the RNL-4 epitope incorporates this Asp-Ser-Thr sequence. Since some neuroblastoma cell lines have been described to express $\alpha$-smooth muscle actin [29], and we observed a strong reaction in SK-N-SH with RNL-4, this cell line was checked for the presence of $\alpha$-smooth muscle actin. No immunofluorescence reaction was seen, however, with $\alpha$-sm-1 (data not shown). The nature of the $45 \mathrm{kDa}$ band in these cell lines remains therefore elusive, but may be related to the occasionally observed membrane-associated staining reaction of RNL-4.

\section{NSP-C and NSP-A associate independently with the ER}

Immunofluorescence studies of COS-1 cells transfected with NSP-C CDNA show a strong staining of the ER with POL-8 and RNL-4, indicating that NSP-C can associate with or incorporate into these endomembranes independently of other NSPs. Also in various neural and NE cell lines which express only NSP-C a similar ER association can be seen, indicating that also under physiological conditions NSP-C can occur in the ER independently of NSP-A. It is known from earlier studies [4] that NSP-A polymerizes into large complexes (NSP-reticulons) which are associated with the ER in the SCLC cell lines NCI-H 82 and SCLC-21H. A dot-like staining for NSP C, which was clearly discernable in the periphery of spreading cells of different origin, indicates that also this protein may form such reticulons. The immunoprecipitation data of this study suggest that in cell line SCLC-21H NSP-C and NSP-A do not copolymerize to form such clusters.

\section{NSPs are present in growth cones}

In several cell lines, i.e. the non-SCLC-NE cell line NCI-H810, the SCLC cell line NCI-H524 and the neuroblastoma cell lines SK-N-SH and CHP-212, a strong NSP immunostaining is detected in the long extensions that these cells can form and which have been described as neuritic outgrowths in case of the neuroblastoma cell lines [16]. This staining intensity was often highest in the tip of these extensions, which may 
represent growth cones. A striking observation in this respect was made in the COS-1 cells expressing NSP-C, which show extensive extensions in virtually all the transfected cells. This phenomenon was much less obvious in COS-1 cells transfected with NSP-A or NSP-B CDNA. The extensions were strongly positive for NSP-C antibodies, often with an even stronger immunoreactivity in the growth cones. Such processes occasionally exhibit strongly NSP C positive accumulations (data not shown), resembling the varicosities described in neuroblastoma cell lines in which concentrations of synaptic vesicles are found [30]. Axonal ER has been described to play a crucial role in the rapid anterograde transport of a variety of membrane macromolecules, important for the formation of synaptic vesicles and packaging of secretory products [31]. On basis of its localization we suggest that NSP-C may play a role in these processes either independently or in conjunction with NSP-A. Furthermore, Terasaki et al. [32] have suggested that newly extended ER membranes may play a role in the ragulation of motile activity, the lamellipodia serving as a sink for calcium. In this respect, a recent study by Feany and Buckley [33], showing the formation of filopodial extensions in fibroblasts after stable transfection with synaptotagmin DNA, may be of interest. This synaptic vesicle associated protein, that has been classified as a $\mathrm{Ca}^{2+}$-sensor, was suggested to link neuronal activity with neuritic outgrowth. It is to be elucidated in future studies whether or not NSPS have such a capacity to influence cell morphology.

\section{NSP-C and NSP-A are differentially expressed in neural and neuroendocrine tissues and cells}

The expression patterns of NSP-A in normal human tissues and malignancies have been described [2,3], but little was known so far about the tissue distribution patterns of NSP-C. NSP-A expression is predominantly found in normal human neural and NE tissues as well as in malignancies derived there from $[2,3]$. For NSP-C a more restricted expression pattern is found, in that many cells of the diffuse $\mathrm{NE}$ system do not contain NSP-C in contrast to NSP-A. Also, a remarkable difference between NSP$A$ and NSP-C expression has been found in Purkinje cells and their dendrites, in which high levels of NSP-A and no NSP-C was detected. Conversely, a much broader expression of NSP-C is observed in peripheral nerves of various tissues, in which NSP-A could not always be detected. In general, NSP-C seems to be expressed in some tissues of neuroectodermal origin i.e., the central and peripheral nerve system, the neurohypophysis and adrenal medulla. In addition the protein is expressed in the cells of the adenohypophysis, pars intermedia and a few NE cells in the bronchus. In the adenohypophysis NSP-C expression was principally found in the central part of this organ, which suggests a possible correlation with corticotrophs secreting ACTH, Blipotropin, a-melanocyte-stimulating hormone and B-endorphin, which are also concentrated in the median portion of the gland [22]. Also the epithelial cells lining the cysts located in the pars intermedia, which are predominantly of the proopiomelanocortin producing type $[34]$, show NSP-C expression.

The differential NSP expression patterns observed in the tissues is to a certain extent reflected in the cell lines derived from these tissues. The underlying study as wall as our previous work has shown that NSP-A and NSP-C are expressed in neural and NE tumor cell lines and not in non-neural/NE tumor cell cultures [3,4]. For example, both proteins are expressed in SCLC cell lines and in non-SCLC cell lines with NE 
characteristics, but not in typical non-SCLC cell cultures (Senden et al.: NSPreticulons as independent markers for non-small cell lung cancer with neuroendocrine differentiation, submitted). Although some of these NE lung cancer cell lines coexpress NSP-C and NSP-A, several of these cultures contain either NSP-A or NSP-C. The results with neuroblastoma cell lines are in accord with our finding that peripheral nerve cells and ganglion cells contain high concentrations of NSP-C and are often negative for NSP-A. Roebroek et al. [1] have shown that neuroblastoma cell lines CCl127 and SK-N-SH (HTB-11) transcribe NSP-C at high levels, and contain hardlly any detectable NSP-A mRNA. We could show that SK-N-SH strongly expresses NSP-C in combination with a low level of NSP-A. In the colon carcinoma cell line NCI-H716, known to express NE markers such as DDC-activity and dense core granules [15], NSP-A expression and no NSP-C is found, in accordance with the in vivo observation that NE cells of the gastro-intestinal tract express NSP-A, but not NSP-C.

\section{NSPs as tumor markers}

Because of the fact that NSP-A and NSP-C are to a certain extent differentially expressed in the NE cell lines, the use of a combination of antibodies to both NSP. subtypes is recommended for the detection of NE differentiation in malignancies. For example, inconsistent expression of NSP-A is not only found in SCLC cell lines, but is also reflected in the NSP-A immunostaining resulis of solid SCLC with approximately one third of the cases tested being NSP-A negative [3]. Because of the cross-reactivity with macrophages (NSP-A sera) and smooth muscle/myoepithelial cells (RNL-4), NSPantibodies are to be used in combination with other morphological and immunohistochemical markers. However, since NSP-reticulon expression is independent of the presence of neurosecretory vesicles (Senden et al.: NSP-reticulons as independent markers for non-small cell lung cancer with neuroendocrine differentiation, submitted), they are expected to be more sensitive in poorly differentiated malignancies with NE differentiation than these vesicle associated proteins. This may be of particular importance in case of bronchopulmonary neoplasm. We are currently studying the expression of NSP-C in lung cancers in relation to NSP-A and to other conventional NE markers. Furthermore, it is obvious that NSP-C may be a good candidate to use for the diagnosis of neuroblastomas, in particular those occurring outside the central nervous system. It has to be examined whether or not NSP-C can be used as a indicative parameter for neural deriviation in for example the small round cell tumors of childhood. Such studies will indicate whether NSP-C, either alone or in combination with NSP-A, is a reliable diagnostic marker.

\section{Acknowledgements}

The authors thank Dr G Bepler (Durham, NC, USA), Dr D Carney (Dublin, Ireland), Dr L de Ley (Groningen, The Netherlands), Dr H Oie (Rockville, MD, USA), Dr C Gropp (Marburg, Germany), Dr A De Brume (Maastricht, The Netherlands), Dr R Michalides (Amsterdam, The Netherlands) and Dr F Smedts (Nijmegen, The Netherlands) for supplying cell lines and human tissues. Furthermore, we thank Dr K Cambell (lowa City, IA, USA) for the antibody IID8, Dr C Smets (Janssen Pharmaceutica, Beerse, Belgium) and Dr G Freling (Maastricht, The Netherlands) for helpful suggestions and M. Pijls for technical assistance. This work was supported by the Netherlands Cancer Foundation, grant no. IKL 90-09. 


\section{Chapter 4}

\section{RERERECES}

1. Roebroek AMM, wan de Velde HJK, Yan Bokhoven A, Broers LLV, Ramaekers FCS, Van de Ven WJM. Cloning and expression of allemative transcripts of a novel newroendocrine-specific gene and identification of its $135-\mathrm{kD}$ a translational product. J Biol Chem 268 : 13439-13447, 1993.

2. Broers JLY, Mijhheere EP, Klein Rot M, Schaart G, Sijlmans A, Boerman OC, Ramaekers FCS. Novel antigens charactetistic of neuroendocrine malignancies. Cancer 67:619-633, 1991

3. Van de Velde HJK, Sender MHM, Roskams TAD, Broers JLV, Ramaekers FCS, Roebroek AJM, Van de Ven WJM. NSP-encoded reticulons are neuroendocrine markers of a novel category in human lung cancer diagnosis. Cancer Res 54: 4769-4776, 1994.

4. Senden NHM, van de Velde HJK, Broers JLV, Timmer EDJ, Kuijpers JH, Roebroek AJM, Van de Ven WIM, Ramaekers FCS. Subcellular localization and supramolecular orgarization of neuroendoerine-specific protein B (NSP-B) in small cell lung cancer. Eur J Cell Biol 65: 341-353, 1994.

5. Van de Velde HJK, Roebroek AJM, Senden NHM, Ramaekers FCS, Van de Ven WJM. NSPreticulons, neuroendocrine proteins of a novel gene family associated with membranes of the endoplasmic reticulum. I Cell Sei 107: 2403-2416, 1994.

6. Van de Velde HIK, Roebroek AJM, Van Leeuwen FW, Van de Ven WIM. Molecular analysis of expression in rat brain of $N S P-A$, a novel neuroendocrine-specific protein of the endoplasmic reticulum. Mol Brain Res 23:81-92, 1994.

7. Bepler $G$, Jaques $G$, Koehler A, Gropp C, Havemann K. Neuroendocrine markers, classical tumor markers, and chromosomal characteristics of permanent human small cell hing cancer cell lines. J Cancer Res Clin Oncol 113: 253-259, 1987.

8. Bepler $G$, Koehler $A$, Kiefer P. Havemann $K$, Beisenherz $K$, Jaques $G$, Gropp $C$, Haeder $M$. Characterization of the state of differentiation of six newly established human non-small-cell lung cancer cell lines. Differentiation 37: 158-171, 1988.

9. Broers ILV, Klein Rot M, Oostendorp T, Bepler G, de Leij L, Carney DN, Vooijs GP, Ramaekers FCS. Spontaneous changes in intermediate filament protein expression patterns in lung cancer cell línes. J Cell Sci 91: 91-108, 1988.

10. Brower M, Carney DN, Oie HK, Gazdar AF, Minna JD. Growth of cell lines and clinical specimens of human non-small cell lung cancer in a serum-free defined medium. Cancer Res 46 : $798-806,1986$

11. Carney DN, Gazar AF, Bepler G, Guccion JG, Marangos PJ, Moody TW, Zweig MH, Minna ID. Establishment and identification of small cell lung cancer cell lines having classic and variant features. Cancer Res 45: 2913-2923, 1985.

12. De Leij L. Postmus PE, Buys CHCM, Elemd JD, Ramaekers F, Poppena S, Brouwer M, wan der Veen AY, Mesander $G$, The TH. Characterization of three new, "wariant-iype cell lines derived from small cell carcinoma of the lung. Cancer Res $45: 6024-6033,1985$.

13. Gazdar AF, Carney DN, Nau MM, Minna JD. Characterization of variant subclasses of cell lines derived from small. cell lung cancer having distinctive biochemical, morphological, and growth properties. Cancer Res 45: 2924-2930, 1985.

14. Lan MS, Russell EK, Lu J, Johnson BE, Notkins AL. 1A-1, a new marker for neuroendocrine differentiation in human lung cancer cell lines. Cancer Res 53: 469-4171, 1993.

15. Park J G, Oie HK, Sugarbaker PH, Henslee JG, Chen TR, Johnson BE, Gazdar A. Charaiteristics of cell lines established from human colorectal carwinoma. Cancer Res 47: 6710-6718, 1987.

16. Rigby CC, Franks LM. A human tissue culture cell line from a transitional cell tumour of the urinary bladder: growth, chromosome pattern and ultrastructure. Br J Cancer 24: 746-754, 1970.

17. Sehlesinger HR, Gerson JM, Moorhead PS, Maguire H, Hummeler K. Establishment and characterization of human neuroblastoma cell lines. Cancer Res $36 ; 3094-3100,1976$.

18. Biedler IL, Helson L. Spengler BA. Morphology and growth, tumorigenicity, and cylogenetics of luman neuroblastoma cells in continuous culture. Cancer 2 es $33.2643-2652,1973$.

19. Tam JP, Zavala $F$. Multiple antigen peptide: a novel approach to increase detection sensitivity of synthetic peptides in solid-phase immunoassays. J Tmmunol Meth 124:53-61, 1989.

20. Boersma WJA, Bogaerts WJC, Bianchi ATJ, Claassen E. Adjuvant properties of stable water-inoil emulsions: evaluation of the experience with Specol. Res Immunol 143: 503-511, 1992.

21. Senden NHM, Van de Velde HJK, Broers JLV, Timmer EDJ, Roebroek AJM, Van de Ven WJM, Ramackers FCS. Cluster 10 lung cancer antibodies recognize NSPs, novel neuroendocrine proteins associated with nembranes of the endoplasmic reticulum. Int I Cancer suppl 8 : $84-88,1994$. 
22. Lloyd RV. Endocrine Pathology. Springer-Verlag, New York, 1990.

23. Wiedenmann B, Huttner WB. Synaptophysin and chromogranins/secretogranins-widespread constituents of distinct types of neuroendocrine vesicles and new tools in tumor diagnosis. Virch Arch B Cell Pathol 58: 95-121, 1989.

24. Jorgensen AO, Arnold W, Pepper DR, Kahl SD, Mandel F, Campbell KP. A monoclonal antibody to the $\mathrm{Ca}^{2+}$-ATPase of cardiac sarcoplasmic reticulum cross reacts with slow type I but not with fast type II canine skeletal muscle fibers: an immunocytochemical and immunochemical study. Cell Motil Cytoskel 9: 164-174, 1988.

25. Skalli O, Ropraz P, Trzeciak A, Benzonana G, Gillessen D, Gabbiani G. A monoclonal antibody against $\alpha$-smooth muscle actin: a new probe for smooth muscle differentiation. J Cell Biol 103 : $2787-2796,1986$.

26. Broers JLV, Ramaekers FCS, Klein Rot M, Oostendorp $T$, Huysmans $A$, van Muijen GNP, Wagenaar SSc, Vooijs GP. Cytokeratins in different types of lung cancer as monitored by chain -specific monoclonal antibodies. Cancer Res 48: 3221-3229, 1988.

27. Stahel RA, Gilks WR, Lehmann H-P, Schenker T. Third International Workshop on Lung Tumor and Differentiation Antigens: overview of the results of the central data analysis. Int I Cancer suppl 8: 6-26, 1994.

28. De Bruïne AP, Dinjens. WNM, Pijls MMJ, vd Linden EPM, Rousch MJM, Moerkerk PT, de Goeij AFPM, Bosman FT. NCI-H716 cells as a model for endocrine differentiation in colorectal cancer. Virchows Archiv B Cell Pathol 62: 311-320, 1992.

29. Sugimoto T, Ueyama H, Hosoi H, Inazawa J, Kato T, Kemshead JT, Reynolds CP, Gown AM, Mine H, Sawada T. Alpha-smooth-muscle actin and desmin expressions in human neuroblastoma. cell lines. Int J Cancer 48: 277-283, 1991.

30. Israel MA, Thiele $\mathrm{CJ}$. Tumor cel】 lines of the peripheral nervous system. In: Atlas of human tumor cell lines. RJ Hay, J-G Park, A Gazdar (eds), Academic Press, San Diego, pp 43-78, 1994.

31. Broadwell RD, Cataldo AM. The neuronal endoplasmic reticulum: Its cytochemistry and contribution to the endomembrane system. II. Axons and terminals. I Comp Neurol 230:

$231-248,1994$.

32. Terasakii M, Chen LB, Fujiwara K. Microtubules and the endoplasmic reticulum are highly interdependent structures. J Cell Biol 103: 1557-1568, 1986.

33. Feany MB, Buckley $\mathrm{KM}$. The synaptic vesicle protein synaptotagmin promotes formation of filopodia in fibroblasts. Nature 364: 537-540, 1993.

34. Halmi NS. The hypophysis. In: Cell and tissue biology: L. Weiss (ed). Urban \& Schwarzenberg, Baltimore, pp 973-994, 1988.

35. Navone F, Jahn $R$, Di Gioia G, Stukenbrok H, Greengard P, De Camilli P. Protein p38: an integral protein specific for small vesicles of neurons and neuroendocrine cells. I Cell Biol 103: $2511-2527,1986$.

36. Jahn $R$, Schiebler $W$, Ouimet $C$, Greengard P. A 38,000-dalton membrane protein (p38) present in synaptic vesicles. Proc Natl Acad Sci USA 82: 4137-4141 1985.

37. Nolan JA, Trojanowski JQ, Hogue-Angeletti R. Neurons and netroendocrine cells contain chromogranin: detection of the molecule in normal bovine tissues by immunochenical and inmunohistochemical methods. J Histochem Cytochem 33: 791-798, 1985.

38. Lloyd RV, Wilson BS. Specific endocrine tissue marker defined by a monoclonal antibody. Sclence 222: $628-630,1983$. 


\title{
CHAPTER 5
}

\section{NSP-ENCODED RETICULONS ARE NEUROENDOCRINE MARKERS OF A NOVEL CATEGORY IN HUMAN LUNG CANCER DIAGNOSIS}

\author{
Helgi JK van de Velde, Nicole HM Senden, Tania AD Roskams, \\ Jos LV Broers, Frans CS Ramaekers, Anton JM Roebroek, Wim JM Van de Ven
}

Cancer Research 54: 4769-4776, 1994

\begin{abstract}
The NSP-gene was recently shown to constitute the prototype of a novel gene family, to be selectively transcribed in neural and endocrine cells, and to encode three overlapping proteins, NSP-A, NSP-B, and NSP-C. These proteins were collectively designated reticulons, because they were found to be anchored to membranes of the endoplasmic reticulum (ER) through their common carboxy-terminal regions. The goal of the present study was to determine whether the reticulons might be used as markers for neuroendocrine (NE) differentiation in human lung tumors. Therefore, the tissue distribution of NSP-A was studied and expression in human lung tumors was evaluated. Immunohistochemical analysis of normal tissues with monoclonal antibodies (mabs) specifically recognizing NSP-A indicated that NSP-A exhibits a distinct NE distribution paltern since it was found to be expressed in a variety of cells with an established NE phenotype but not in cells lacking such features. Results with specimens of a wide variety of primary human tumors provided further support for this. Immunohistochemical analysis of primary lung carcinomas revealed that NSP-A was readily detectable in small cell ling carcinomas (SCLCs) (8 of 12) and carcinoid tumors of the lung ( 3 of 3 ) but not in nonNE non-SCLCs $(0$ of 10$)$. In 13 of 27 non-SCLCs expressing the neural cell adhesion molecule (NCAM) and/or neurofilament proteins, however, NSP-A was found to be expressed. Northern blot analysis of human lung carcinoma cell lines revealed expression of NSP-A and/or NSP-C encoding mRNAs in all 18 SCLC cell lines that were studied, except one; however, no expression of these mRNAs could be detected in any of the 11 non-SCLC cell lines tested. The NSP transcript encoding NSP-B was found only in SCLC cell line NCI-H82. In conclusion, the results of our studies suggest that, in lung tumor cells, expression of NSP-A and most likely also NSP-C is restricted to cells with a NE phenotype.
\end{abstract}




\section{INTRODUCTION}

Proteins that are selectively expressed in neural and endocrine cells are of interest as discriminating markers in cell typing during biological development as well as in differential diagnosis of tumors in general and of lung carcinomas in particular [1]. NE markers in normal and malignant bronchopulmonary tissues are NCAM [2], neuronspecific enolase (NSE) [3], or secretory vesicles-associated proteins, such as chromogranin A [4], gastrin releasing peptide (GRP) [5], and synaptophysin [6].

Recently, we have identified and characterized a novel gene, which was designated NSPgene (Neuroendocrine-Specific Protein-gene) [7], because Northern blot analysis indicated that it is specifically expressed in neural and endocrine tissues. The NSP-gene has been mapped by fluorescence in situ hybridization analysis to human chromosome $14 \mathrm{q} 21-\mathrm{q} 22$ [8]. A computer data base search revealed NSP-related sequences in close proximity to the ERCCl locus on human chromosome $19 \mathrm{q} 13.3$, indicating that NSP is the prototype of a larger gene family [9]. Expression of the NSP-gene appears to result in 3'-end overlapping transcripts encoding carboxy-terminally overlapping proteins. Mostly, 3,4 and $1,8 \mathrm{~kb}$ were detected; only in the SCLC cell line NCI-H82, expression of high levels of a NSP transcript of $2.3 \mathrm{~kb}$ was found as well. Biosynthesis, post-translational modification, and subcellular localization of the NSP-gene encoded proteins have also been studied $[9,10]$. We have found that NSP-A is a protein with a molecular weight (Mw) of about $135 \mathrm{kDa}$, which occurs in various isoforms presumably depending on the degree of phosphorylation in serine residues. NSP-B is a phosphoprotein with a Mw of about $45 \mathrm{kDa}$. NSP-C is a protein with a $\mathrm{Mw}$ of $23 \mathrm{kDa}$, which is not phosphorylated. The NSPs appeared to be tightly anchored through their common carboxy-terminal regions to microsome membranes and to colocalize with SERCA2b, a membrane-associated $\mathrm{Ca}^{2+}$ ATPase of the endoplasmic reticulum (ER) $[11,12]$. Because of the latter feature, we also refer to the NSPs as reticulons. Immunohistochemical analysis of rat brain with anti-NSPA mabs indicated that NSP-A is highly expressed in many brain regions, particularly in cerebellar Purkinje cells, in neurons of the superior colliculus and of the piriform and enthorhinal cortex, in fibres of the basal ganglia and several hippocampal regions including CA3 (stratum lucidum) and the dentate gyrus, in the induseum griseum and in the subcommissural organ, suggesting a role of NSP-A in many areas of the brain [13]. Here, we report investigations of whether the NSP-gene encoded proteins might constitute NE markers in human lung cancer diagnosis. First, we have performed Western blot and immunohistochemical analyses of various tissues and tumor types with anti-NSP-A mabs to determine the tissue distribution of NSP-A. The initial suggestion from Northern blot analysis, that expression of the NSP-gene might be restricted to neural and endocrine cells [7], was confirmed by the NE-specific tissue distribution of NSP-A. Subsequently, primary human lung tumors were studied, to evaluate the potential of NSP-A as marker for NE lung tumors. Furthermore, Northern blot analysis of SCLC and non-SCLC cell lines was performed to evaluate expression of NSP-A and NSP-C in cultured lung tumor cells. In the present report, we provide evidence that the NSPS are selectively expressed in NE tumor cells of the lung and, because they are the first NE proteins known to be anchored to membranes of the ER, they represent NE markers of a novel category. 


\section{Cell lines and tumor specimens}

Specimens of normal tissues and tumors used in this study are listed in Tables 1, 2, and 4. They were selected from the files of the Pathology Departments of the University Hospital Leuven, Belgium, and of the St. Anthonius Hospital, Nieuwegein, The Netherlands. Tumors were characterized by routine microscopic and histopathological techniques and classified according to established criteria. In general, tissue specimens were quickly frozen in liquid nitrogen after resection and stored at $-80^{\circ} \mathrm{C}$. Formalin-fixed and paraffun-embedded specimens were also used.

Cell lines used in this study are listed in Table 3 and included: human lung carcinoma cell lines GLC-1, GLC-1-M13, GLC-14, GLC-16, GLC-19 and GLC-28 [14,15]; SCLC$16 \mathrm{HC}$, SCLC-16HV, SCLC-21H and SCLC-22H [16,17]; NL-SCLC3 [18]; and NCIH417, NCI-H524, and NCI-H526 (cell pellets of latter three cell lines were kindly provided by D. Carney). All other lung carcinoma cell lines were obtained from the American Type Culture Collection (ATCC). Cells were grown in DMEM/Ham's F12 (1/1) medium supplemented with $10 \%$ fetal bovine serum (GIBCO-BRL).

\section{RNA isolation and Northern blot analysis}

Total RNA was isolated using the lithium-urea procedure described by Auffray and Rougeon [19]. For Northern blot analysis, $15 \mu \mathrm{g}$ of total RNA was glyoxylated [20], sizefractionated on a $1 \%$ agarose gel and transferred to Hybond- $\mathrm{N}$ (procedure as recommended by Amersham). Northern blots were hybridized according to the procedures of Church and Gilbert [21] with the NSP cDNA insert of pAB124 [7] as molecular probe. For quantity and quality control of the RNA samples, Northern blots were dehybridized and checked by rehybridization with a hamster B-actin cDNA probe [22].

\section{Western blot analysis}

Tumor specimens were lysed in lysis buffer $(62.5 \mathrm{mM}$ Tris- $\mathrm{HCl}(\mathrm{pH} 6.8), 12.5 \%$ glycerol, $2 \%$ Nonidet P-40, containing as protease-inhibitors $2.5 \mathrm{mM}$ phenylmethylsulphonyl fluoride (PMSF), $1.25 \mathrm{mM}$ ethylenediamine tetra-acelic acid (EDTA) and $12.5 \mu \mathrm{g} / \mathrm{ml}$ leupeptin). Approximately equal amounts of cell lysates were loaded on $7.5 \%$ polyacrylamide gels and subjected to sodium dodecyl sulphate polyacrylamide gel electrophoresis (SDS-PAGE) under reducing conditions according to Laemmli [23]. Western blot analysis was performed as described before [7,13,24]. A 1:6 dilution of a mixture of MON-160, MON-161 and MON-162 [13] was used as primary antibody. These mabs have been generated by immunizing mice with partially purified hybrid protein BGal-NSP-A6-776 and were shown to recognize only NSP-A. The epitope regions in NSP-A that are recognized by these antibodies have been mapped and the relative positions in the protein are indicated in Fig. 1, chapter 2. In negative control experiments, the primary antibody was replaced by a 1.6 dilution of $\mathrm{Sp} 2 / 0$ myeloma supernatant.

\section{Immunohistochemistry.}

Human tissue material was available either as frozen tissue blocks stored in liquid nitrogen or as routinely formalin-fixed and paraffin-embedded specimens. Fresh rat tissues were obtained from nine weeks old male Wistar rats and stored at $-80^{\circ} \mathrm{C}$. Immunohistochemical 
staining procedures were performed as described before [25]. Briefly, the cryostat sections ( $5 \mu \mathrm{m}$ thick) were fixed in acetone for $5 \mathrm{~min}$, whereas the paraffin-embedded sections were deparaffinized and rehydrated. The sections were incubated in a $1: 5$ dilution of a mixture of MON-160, MON-161 and MON-162. After washing, sections were exposed to a 1:400 dilution of biotinylated rabbit-anti-mouse antiserum (Dako A/S). After several subsequent washing steps, sections were incubated with streptABComplex/horseradish peroxidase (Dako A/S). All incubations and washes were performed at room temperature. Immunoreactivity was visualised by exposing the cryostat sections to 3-amino-9ethylcarbazole (Janssen) and the paraffin-embedded sections to 3,3'-diaminobenzidine-HCl (Sigma). After counterstaining with Mayer's hematoxylin, sections were mounted and examined under a Leitz microscope. In negative control sections, the primary monoclonal antibodies were omitted.

\section{RESULTS}

Immunohistochemical analysis of NSP-A expression in normal human and rat tissues. The main objective of this study was to investigate whether the NSP-gene encoded proteins could be used in differential diagnosis of human lung tumors. The suggested neuroendocrine-specific expression pattern of the NSP-gene, as observed in Northern blot analysis, formed the basis for this study. Furthermore, the fact that the NSPs were shown to be tightly associated with membranes of the ER implied that these proteins might constitute markers of a novel category. To achieve our objective, we first performed immunohistochemical analyses to establish the distribution of NSP-A in a variety of normal human and rat tissues. The rationale for focusing our attention on NSP-A was based on the fact that we had obtained mabs that specifically recognize NSP-A and did not react with either NSP-B or NSP-C [13]. These antibodies included MON-160, MON161 , and $M O N-162$, and they are all of the IgG1 subclass. The antibodies had been raised against partially purified hybrid protein BGal-NSP-A6-776, which also encompasses all sequences of NSP-B and NSP-C, except for the first twenty amino-terminal residues of NSP-C. Regions in NSP-A, which harbor the epitopes recognized by the three mabs, are indicated in Fig. 1, chapter 2. In immunoprecipitation and Western blot experiments, it was established that each of the three mabs reacted only with the $135 \mathrm{kDa}$ NSP-A $[7,13]$. In addition to human NSP-A, the antibodies also recognized mouse, rat, and hamster NSP-A, allowing analysis of tissues for which it appeared difficult to obtain human samples. A combination of the three antibodies was routinely used in the immunohistochemical experiments, since this gave stronger staining results as compared to the application of an individual mab. Altogether, the results of these pilot studies clearly indicated that the three Mabs were suitable for immunological analysis of NSP-A expression.

The reactivity of the combination of the three anti-NSP-A mabs toward the different types of normal human and rat tissues is summarized in Table 1 and illustrated in Fig. 1. Reactivity toward different types of human tumors, except tumors of the lung which are described and discussed in more detail separately, is summarized in Table 2 and illustrated in Fig. 1. It should be noted that reactivity of the mabs toward brain tissue was studied in great detail in a previous study [13]. Results of this study are included in Table 1 but not further discussed here. In normal tissues, the antibodies appeared to react with cells 
of the islets of the pancreas, anterior and posterior lobe of the pituitary gland, calcitoninproducing cells of the thyroid, medulla of the adrenal gland, plexus of the small intestine, and enterochromaffin cells of stomach and small intestine, but not with cells of the acini of the pancreas, cortex of the adrenal gland, esophagus, gastric glands of the stomach, small intestinal glands, kidney, liver, spleen, skin, submandibular gland, tongue, and testis. In similar analysis of human tumors, expression of NSP-A was found in neoplasms of the nervous system (in neural but not in glial tumors), pheochromocytoma and medullary adenoma of the adrenal gland, adenoma of the pituitary gland, islet cell tumors but not adenocarcinomas of the pancreas, adenoma of the parathyroid gland, and in carcinoid tumors of the gastro-intestinal tract, the ovarium and in a liver carcinoid metastasis with unknown primary tumor site. Also medullary thyroid carcinomas, a Merkel cell tumor of the skin and a Leydig cell tumor of the testis appeared to be stained. No expression was found in other testis tumors nor in hypernephromas or prostate tumors.

Table 1.

Immunohistachemical analysis of NSP-A expression in normal human and rat tissues

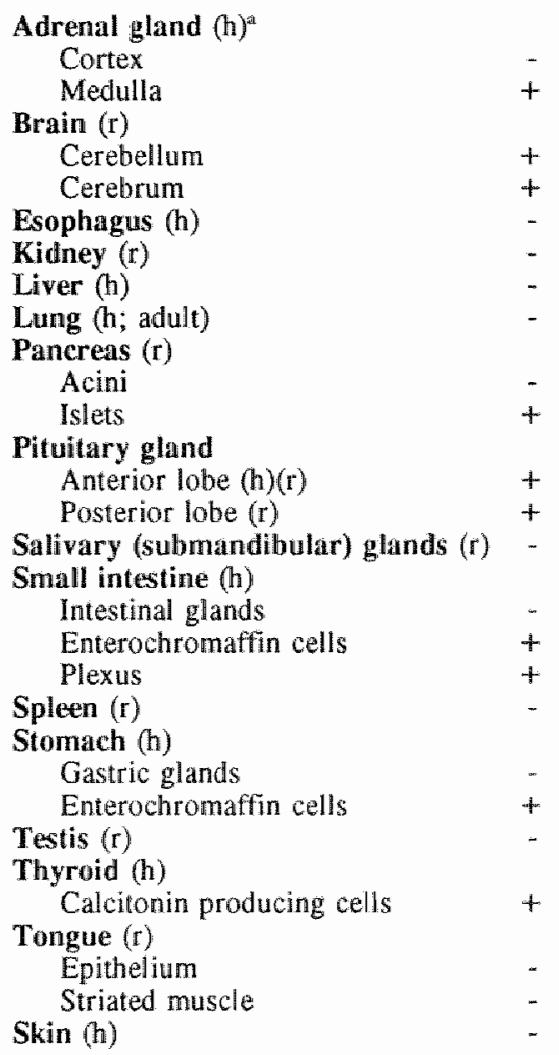

${ }^{\mathrm{a}}(\mathrm{h}),=$ human; $(\mathrm{m}),=$ mouse; $(\mathrm{r}),=$ rat; - , no expression detected; + , detectable expression 

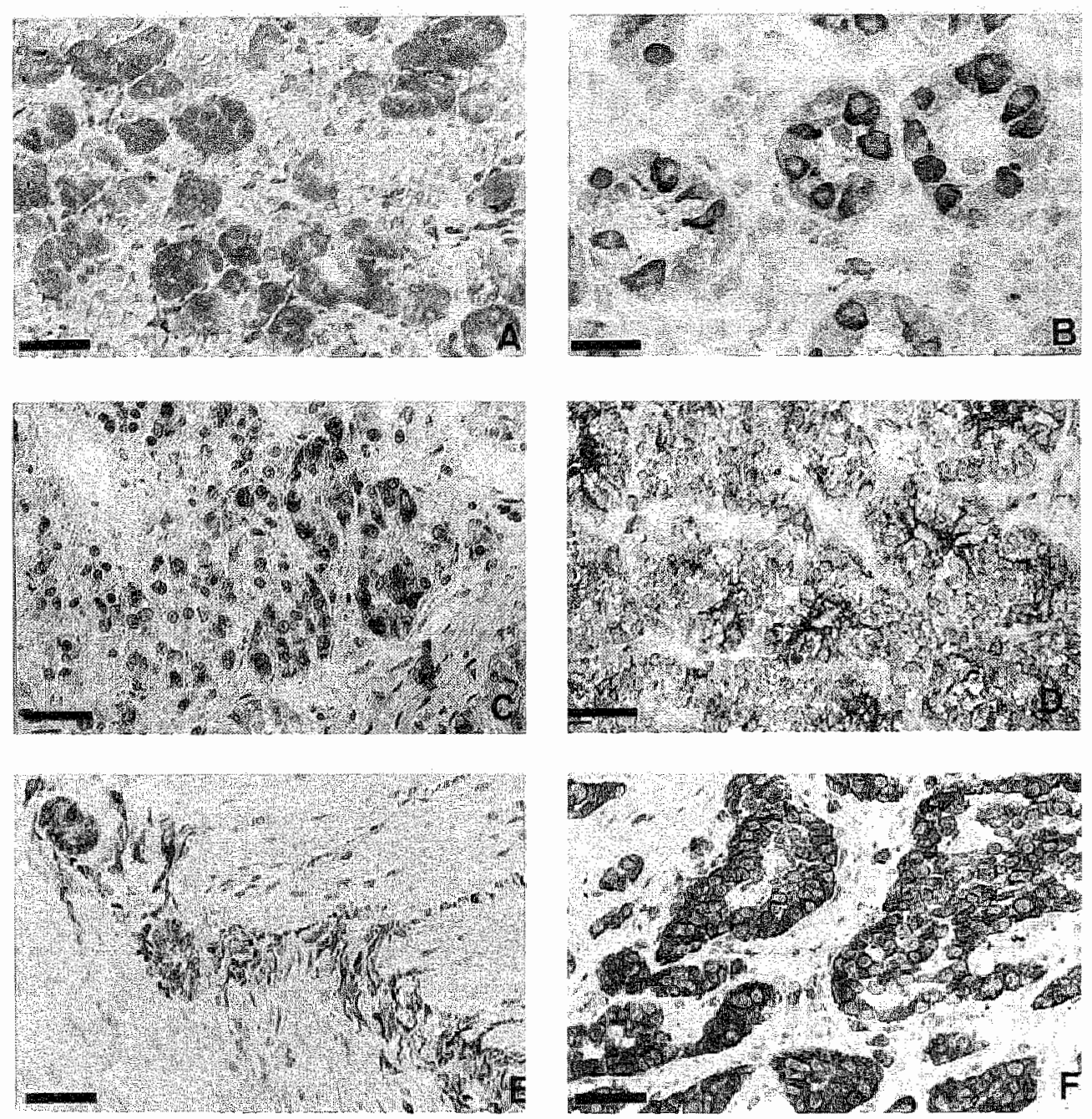

Figure 1. Immunohistochemical detection of NSP-A in human neuroendocrine tissues and tumors using a mixture of MON-160, MON-161 and MON-162. Note reactivity towards cellls of the adrenal medulla (A), hyperplastic gastrin cells in the antral mucosa (B), cells of pituitary gland (C), towards tumor cells of a pituitary adenoma (D), the myenteric plexus $(E)$ and with cells of an intestinal carcinoid tumor $(F)$, Bars: $30 \mu \mathrm{m}(A-D) ; 50 \mu \mathrm{m}(E, F)$.

The immunohistochemical results were further supported by results from Western blot analysis, as illustrated in Fig. 2 for a gastro-intestinal carcinoid, a hyperplastic parathyroid gland, a carcinoid tumor metastasized to the liver, and a medullary thyroid carcinoma. In earlier Western blot studies, we already demonstrated that expression of NSP-A occurs in cerebrum and cerebellum of rat [13]. In human liver, expression of the $135 \mathrm{kDa}$ NSP-A could not be demonstrated (Fig. 3, lane E). 
Table 2.

Immunohistochemical analysis of NSP-A expression in human tumors

Tumor

Adrenal gland

Pheochromocytoma

Medullary adenoma

Gastro-intestinal tract

Adenocarcinoma

Carcinold tumor

Kidney bypernephroma.

Liver metastatic carcinoid

Nervous system

Neuroblastoma

Ganglioneuroblastoma

Fibrothecoma

Paraganglioma

Astrocytoma

Glioblastoma

Oligodendroglioma

Ependymoma

Schwannoma.

Primitive Neuroectodermal Tumor

Ovarium

Dysgerminoma

Carcinoid tumor

Pancreas

Islet cell tumor

Adenocarcinoma

Parathyroid gland

Adenoma

Pituitary gland

Adenoma

Prostate

Adenocarcinoma

Skin

Hyperplasia

Merkell cell tumor

Testis

Seminoma

Mixed germ cell tumor

Leydig cell tumor

Thyroid gland

Medullary thyroid carcinoma
Positives/cases tested 


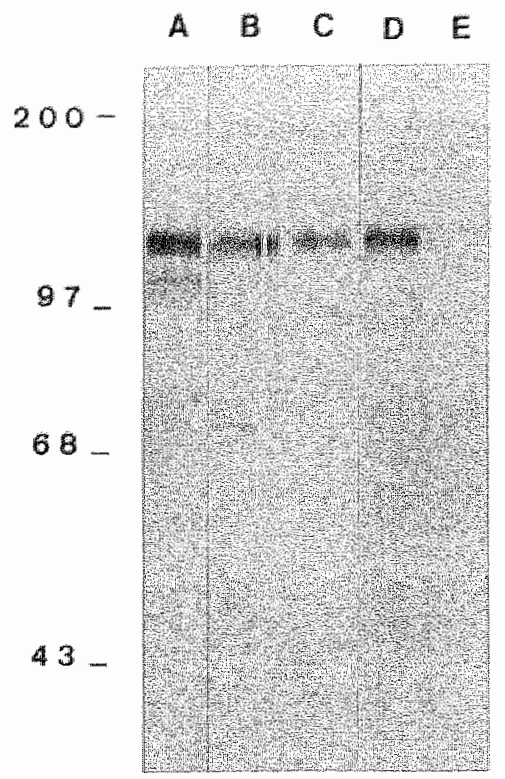

Figure 2. Western blot analysis of NSP-A expression. Reactivity of lysates of a gastrointestinal carcinoid tumor (lane A), a hyperplastic parathyroid gland (lane B), a carcinoid liver metastasis (lane C), a medullary thyroid carcinoma (lane D) and normal liver (lane E) with a mixture of MON-160, MON-161 and MON-162 was tested. Anti-NSP-A immunoreactivity was visualized using a rabbit anti-mouse antiserum conjugated to alkaline phosphatase. Molecular weight markers are indicated.

\section{Northern blot analysis reveals NSP-gene expression in SCLC but not in non-SCLC cell lines}

To evaluate its potential as a marker to differentiate between lung tumors, we subsequently studied NSP-gene expression in human lung tumors. It is well established that human lung tumors frequently display NE features. The minor subgroup of carcinoid tumors of the lung possess overt NE characteristics, whereas the important group of SCLCs display a more restricted NE differentiation pattern. Finally, in the non-SCLCs, NE differentiation is only found in about $10 \%$ of the cases and seems to correlate with a higher response rate to chemotherapy [26]. We first defined the expression pattern of the NSP gene in human lung carcinoma cell lines and performed Northern blot analysis of 18 SCLC and 11 non-SCLC cell lines. In Fig. 3 NSP expression is illustrated, whereas in Table 3, the results of all Northern blot experiments are summarized. In SCLC cell line NCI-H82, probably three transcripts $(3.4 \mathrm{~kb}, 2.3 \mathrm{~kb}$, and $1.8 \mathrm{~kb})$ could be observed (Fig. $3 \mathrm{~A}$, lane 1 ), although the $1.8 \mathrm{~kb}$ transcript is rather difficult to see because of the high levels of expression of the $2.3 \mathrm{~kb}$ transcript. As alreadly noted before, the $2.3 \mathrm{~kb}$ mRNA represents a NSP transcript that can be found thus far only in SCLC NCI-H82. In SCLC$21 \mathrm{H}$, expression of the $3.4 \mathrm{~kb}$ and the $1.8 \mathrm{~kb}$ transcript was found (Fig. 3A, lane 2), with levels of the $1.8 \mathrm{~kb}$ transcript apparently somewhat higher than that of the $3.4 \mathrm{~kb}$ transcript. In the related SCLC cell lines GLC-1-M13 (Fig. 3A, lane 3) and GLC-1 only the $1,8 \mathrm{~kb}$ transcript was detectable, whereas the $3.4 \mathrm{~kb}$ mRNA barely if at all. In SCLC$16 \mathrm{HV}$, only the $3.4 \mathrm{~kb}$ transcript was found (Fig. 3A, lane 5). Expression of the NSPgene, NSP-A and/or NSP-C encoding mRNAS, was found in all SCLC cell lines that were tested by such Northern blot analysis (Fig. 3B, lanes A-F), except for NCI-H526 (see Table 3). In contrast to the SCLC cell lines, expression of NSP could not be detected in any of the 11 non-SCLC cell lines (Table 3). In Fig. 3B, results of non-SCLC cell lines NCI-H23 (lane G), SK-MES-1 (lane H), and SW900 (lane I) are given as an illustration. In Northern blot analysis of lung specimens of human, mouse and rat origin, no NSP expression could be demonstrated (data not shown). Western blot analysis of these cell 
lines with the three anti-NSP-A mabs revealed expression of the $135 \mathrm{kDa}$ NSP-A in SCLC cell lines in which the $3.4 \mathrm{~kb}$ transcript was readily detected (data not shown). In none of the non-SCLC cell lines, expression of the gene nor NSP-A could be demonstrated. The Northern blot data were supported by results of immunoprecipitation analyses of SCLC and non-SCLC cell lines. Such studies, in which a mixture of the mabs MON-160, MON-161 and MON-162 was used, revealed that in SCLC cell lines the $135 \mathrm{kDa}$ NSP-A was synthesized; expression of NSP-A could not be demonstrated in any of the non-SCLC cell lines tested (data not shown).

Table 3.

NSP MRNA expression in human SCLC and non-SCLC cell lines

\begin{tabular}{|c|c|c|}
\hline NSP mRNA & $3.4 \mathrm{~kb}$ & $1.8 \mathrm{~kb}$ \\
\hline \multicolumn{3}{|l|}{ SCLC cell lines } \\
\hline \multicolumn{3}{|l|}{ Classic } \\
\hline GLC-1-M13 & - & $+1-$ \\
\hline $\mathrm{GLC}-14$ & ++ & $t+t$ \\
\hline GLC-16 & + & + \\
\hline GLC- 19 & ++ & ++ \\
\hline GLC-28 & ++ & ++ \\
\hline NCI-H209 & + & + \\
\hline $\mathrm{NCI}-\mathrm{H} 249$ & - & ++ \\
\hline \multicolumn{3}{|l|}{ Transitional } \\
\hline SCLC-16HC & +4 & ++ \\
\hline SCLC-22H & $+1-$ & $+1-$ \\
\hline \multicolumn{3}{|l|}{ Variant } \\
\hline GLC-1 & $+1=$ & $+t+$ \\
\hline NCI-H82 a & ++ & + \\
\hline NCI-H417 & $+t$ & ++ \\
\hline NCI-H446 & - & ot \\
\hline $\mathrm{NCI}-\mathrm{H} 524$ & + & ++ \\
\hline NCI-H526 & - & - \\
\hline NL-SCLC3 & ++ & ++ \\
\hline SCLC-16HV & ++ & - \\
\hline$S C L C-2 \rrbracket H$ & ++ & $+t+$ \\
\hline \multicolumn{3}{|l|}{ Non-SCLC Cell lines } \\
\hline \multicolumn{3}{|l|}{ Squamous cell carcinoma } \\
\hline CALU-I & - & - \\
\hline $\mathrm{NCl}-\mathrm{HS} 20$ & - & - \\
\hline SK-MES-1 & - & 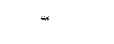 \\
\hline SW 900 & - & - \\
\hline \multicolumn{3}{|l|}{ Adenocarcinoma } \\
\hline A -427 & - & - \\
\hline CALU-3 & - & - \\
\hline NCI-H23 & - & - \\
\hline $\mathrm{NCI}-\mathrm{H} 125$ & - & - \\
\hline NCI-H441 & - & - \\
\hline$S K-L U-\mathbb{L}$ & - & - \\
\hline \multicolumn{3}{|l|}{ Adenosquamous carcinoma } \\
\hline $\mathrm{NCl} \sim \mathrm{H} 596$ & - & - \\
\hline
\end{tabular}

a also expression of high levels $(+++++)$ of $2.3 \mathrm{~kb}$ NSP mRNA; - , negative; +1 , barely detectable; + to $++t$ : increasingly higher levels of NSP expression. 

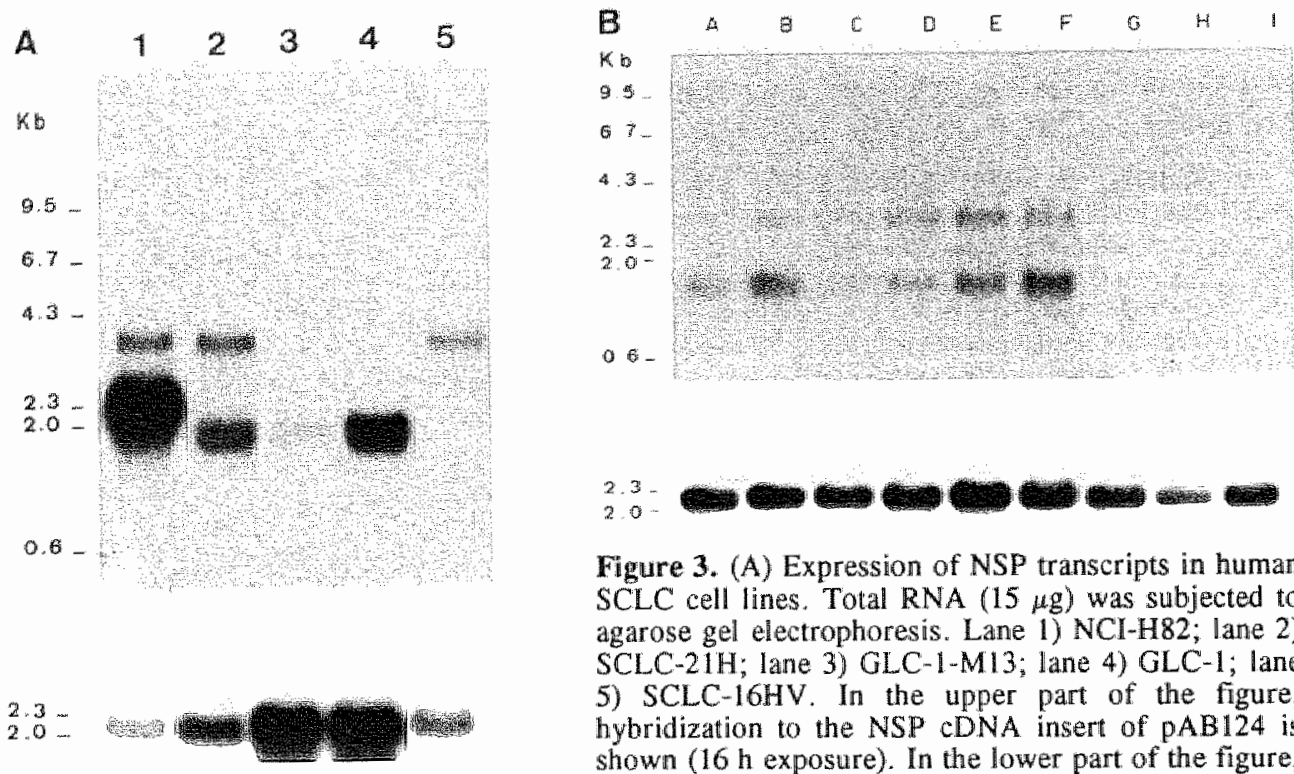

Figure 3. (A) Expression of NSP transcripts in human SCLC cell lines. Tatal RNA (15 $\mu \mathrm{g}$ ) was subjected to agarose gel electrophoresis. Lane 1) NCl-H82; lane 2) SCLC-21H; lane 3) GLC-1-M13; lane 4) GLC-1; lane 5) SCLC $-16 \mathrm{HV}$. In the upper part of the figure, hybridization to the NSP CDNA insert of PAB124 is shown ( $16 \mathrm{~h}$ exposure). In the lower part of the figure, hybridization to a hamster Bactin-specific probe is shown (16 h exposure). (B) Northern blot analysis of differential expression of the NSP gene in human SCLC and non-SCLC cell lines. Total RNA $(15 \mu \mathrm{g})$ was subjected to agarose gel electrophoresis. Lane A) NCIH209; lane B) GLC-14; lane C) GLC-16; lane D) GLC-28; lane E) NL-SCLC3; lane F) NCI-H417; lane G) NCI-H23; lane H) SK-MES-1; lane I) SW 900. Upper panel shows hybridization to the NSP CDNA insert of pAB124 (16 h exposure). Lower panel shows hybridization to a hamster-i)-actin-specific probe (16 h exposure). Molecular weight markers in both figures, $\lambda D$ NA digested with restriction endonuclease HindIrr, are indicated (Kb).

Immunohistochemical analysis of NSP-A expression in primary human fung tumors It is well established that primary human lung tumors can be highly heterogeneous; much more than corresponding cell lines. To further evaluate the potential of NSP-A as a NE marker, reactivity was determined of the mixture of the anti-NSP-A mabs MON-160, MON-161, and MON-162 toward different types of primary human lung tumors. The results are summarized in Table 4 and illustrated in Fig. 4. A positive reaction was found in all three carcinoid tumors of the lung that were tested. Staining was allways strong and observed in virtually all cells, as is shown in Fig. 4A, indicating wide-spread and high levels of NSP-A in these tumor cells. Staining with the anti-NSP-A antibodies was also observed in 8 of the 12 primary SCLCs that were studied. Reactivity appeared to vary from focal staining of some tumor cells ( 3 cases) to a diffuse staining in virtually all tumor cells ( 5 cases), as illustrated in Fig. 5B and 5C. As far as non-NE non-SCLCs are concerned, no NSP-A staining could be observed in the four squamous cell carcinomas (one case illustrated in Fig. 5D), the four adenocarcinomas (one case illustrated in Fig. $5 E$ ) or the two large cell carcinomas (one case illustrated in Fig. 5F) that were tested. It should be noted, however, that NSP-A expression could be demonstrated in 13 of 27 squamous cell carcinomas that were selected on the basis of expression of NCAM and/or neurofilament proteins (Table 4). 

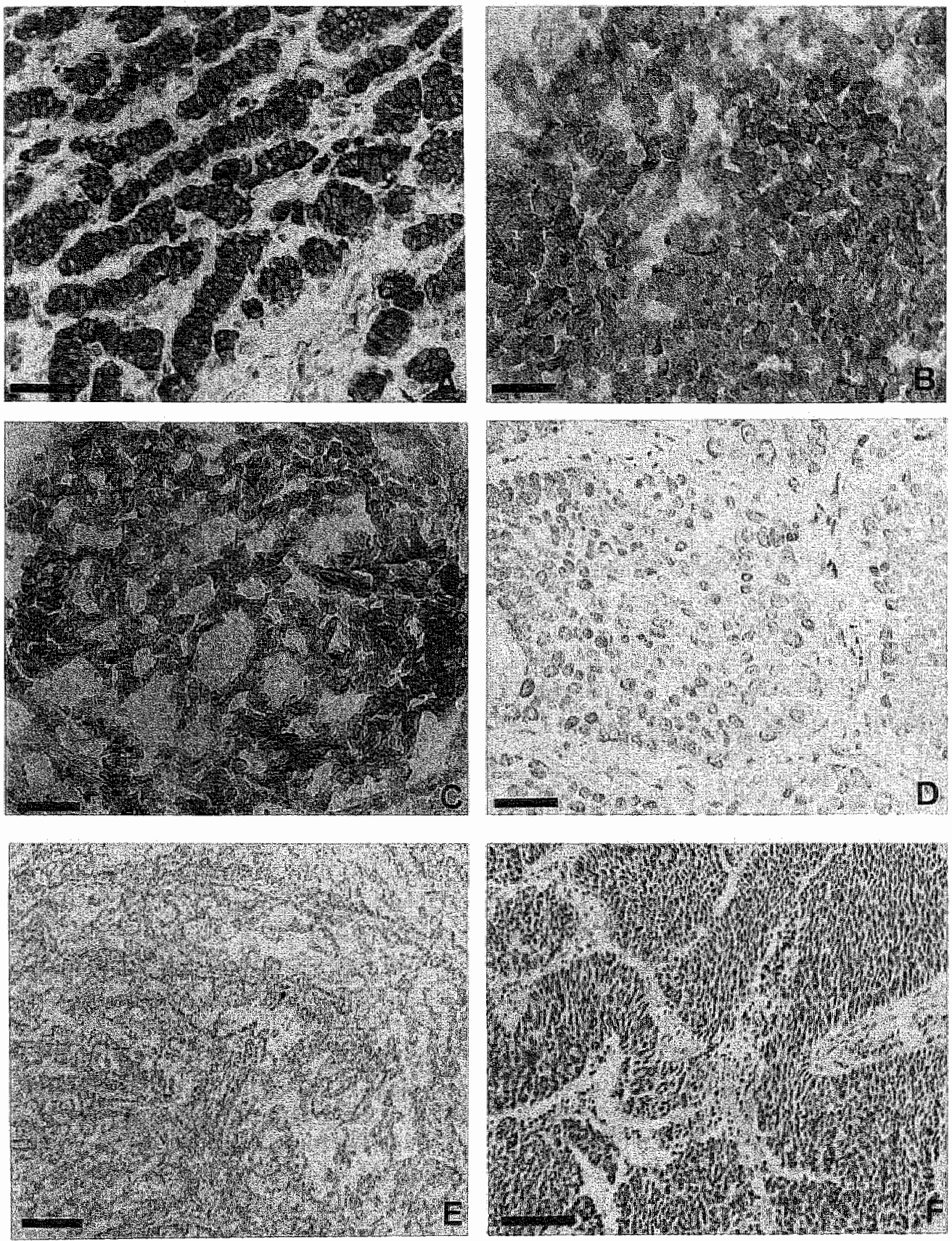

Figure 4. Immunohistochemical detection of NSP-A in primary human lung tumors. Note reactivity of the mixture of monoclonal anti-NSP A antibodies MON-160, MON-161 and MON-162 with tumor cells of a carcinoid tumor (A) and two SCLC tumors (B,C) and lack of reactivity with cells of squamous cell carcinoma (D), adenocarcinoma (E) and large cell carcinoma (F). Bars: $50 \mu \mathrm{m}(\mathrm{A}-\mathrm{D}) ; 100 \mu \mathrm{m}$ (F); 200 $\mu \mathrm{m}(\mathrm{E})$. 
Table 4.

Immunohistochemical analysis of NSP-A expression in human lung tumors

\begin{tabular}{lc}
\hline Lung tumor type & positives/cases tested \\
\hline SCLC & $8 / 12$ \\
Carcinoid tumor & $3 / 3$ \\
Non-SCLC (non-neuroendocrine) & $0 / 10$ \\
\hline
\end{tabular}

\section{DISCUSSION}

In this study, we found that the anti-NSP-A antibodies MON-160, MON-161, and MON162, which were previously shown to recognize different epitopes uniquely present in the $135 \mathrm{kDa}$ NSP-A, seem to reliably stain cells with a known NE phenotype and that they did not react with most, if not all, established non-neural and non-endocrine cell types. The antibodies were shown to stain NSP-A in routinely formalin-fixed and paraffin embedded specimens, although less intensely than in sections of frozen tissue. On the basis of these observations, we conclude that the three anti-NSP-A mabs might constitute valuable immunohistochemical tools for the detection of NE differentiation.

An intriguing aspect of $N E$ differentiation is the frequency at which this is found in pulmonary neoplasms, and therefore, we studied NSP-gene expression in such tumors. It is well established that human lung tumors often display NE features. Carcinoid tumors of the lung possess overt NE characteristics, whereas SCLCs display a more restricted NE differentiation pattern. Finally, in the non-SCLCs, NE differentiation is only found in about $10 \%$ of the cases and seems to correlate with a higher response rate to chemotherapy [26-28]; although other reports question this [29]. We first studied NSPgene expression by Northern blot analysis of human lung carcinoma cell lines, to assess whether the NSP-gene is differentially expressed in well-characterized SCLC, classic as well as variant type, and non-SCLC cell lines. This Northern blot analysis indicated that NSP-gene expression discriminates between the non-NE non-SCLC and the NE SCLC cell lines. The subsequent immunohistochemical study of primary human lung tumors confirmed the differential expression of NSP-A in NE lung tumors (carcinoids and SCLCs) versus non-NE non-SCLC subtypes. Our results on a limited group of nonSCLCs, that were selected on the basis of expression of NCAM and/or neurofilament proteins [18], showed that 13 of $27 \mathrm{NCAM}$ /neurofilament-protein-positive non-SCLCs also expressed NSP, indicating that NSP-A is a NE marker and not a specific marker for SCLC. Further studies are in progress to compare NSP expression to that of other NE markers such as chromogranin, synaptophysin, NSE, and L-dopa decarboxylase activity. The Northern blot analysis of NSP-gene expression in SCLC cell lines revealed that the levels of the $3.4 \mathrm{~kb}$ and $/$ or the $1.8 \mathrm{~kb} \mathrm{NSP}$ transcripts were not significantly different in the variant versus the classic SCLC cell lines. However, variant SCLC are known to have 
lost many other NE characteristics, like the expression of L-dopa decarboxylase, bombesin-like peptide [30] and 7B2 [22], as compared to the classic SCLC cell lines. The comparable expression levells of the NSP-gene in variant and in classic SCLC cell lines suggest that NSP-gene expression might constitute a rather "early" event in the NE differentiation pathway.

There was a discrepancy between the observed NSP-gene expression (17 of 18 ) in SCLC cell lines and the immunohistochemical detectability of NSP-A (5 of 12 diffuse staining and 3 of 12 focal staining) in primary SCLC tumors. This may be due partly to a lower sensitivity of the immunohistochemical detection as compared to Northern blot analysis. This explanation is supported by our observation that the anti-NSP-A antibodies could not stain some SCLC cell lines with rather low levels of the $3.4 \mathrm{~kb}$ NSP transcript, while they could clearly stain SCLC cell lines with higher levels of the $3.4 \mathrm{~kb}$ transcript (data not shown). An additional explanation may be found in the observation that in 3 of 18 SCLC cell lines, NSP-gene expression resulted apparently only in the production of the $1.8 \mathrm{~kb}$ but not the $3.4 \mathrm{~kb}$ NSP transcript. Immunohistochemical detection of NSP-C, the protein corresponding to the $1.8 \mathrm{~kb}$ NSP transcript, would elucidate whether a similar differential expression is present in those primary SCLC tumors which were negative for NSP-A. As we did not succeed in generating antibodies against the common carboxy-terminus of NSP-A and NSP-C, probably due to its high hydrophobicity [13], mabs against the unique NSP-C amino-terminus are currently being developed for this purpose.

Its observed neuroendocrine-specific tissue distribution together with the fact that it is a membrane-anchored component of the ER seem to make NSP-A a NE marker of a novel category, clearly distinct from the established NE markers presently known. At present, nothing is known about possible functions of the NSP-gene encoded proteins. On the basis of their likely association with both smooth and rough ER, one could speculate about their role in transport processes or, because of the multiple predicted transmembrane domains of them, a function in a channel-like complex. Therefore, future studies should not only try to assess their value as NE markers by comparing them to other NE markers, but should also, by elucidating their function, contribute to our knowledge of physiological processes in NE cells.

\section{Acknowledgements}

We thank professor $\mathrm{H}$. Van den Berghe for his continuous support. We are indebted to $\mathrm{R}$ Boullion, $\mathrm{F}$ Ostyn, F Penninckx, C Nackaerts, and Sj Sc Wagenaar for supplying specimens of human tissues and tumors, and to I Pauli, E Timmer, G Vandereyken, and M Willems for excellent technical assistance. This work was supported in part by the "National Fonds voor Wetenschappelijk Onderzoek (NFWO), the "Dutch Cancer Foundation" (project IKL.90-09), and the "Geconcerteerde Onderzoekacties 1992-1996". This text presents results of the Belgian programme on Interuniversity Polles of attraction initiated by the Belgian State, Prime Minister's Office, Science Policy Programming. The scientific responsibility is assumed by its authors. H.J.K. van de Velde is a Research Assistant of the National Fund for Scientific Research (Belgium).

\section{REFERENCES}

1. Mima JD, Higgins GA, Glatstein EJ. In: Cancer: Principles and Practice of Oncology. VT DeVita, S Hellmann and SA Rosenberg (eds). J.B. Lippincott Co., Philadelphia, pp 505-597, 1985.

2. Patel K, Moore SE, Dicksan G, Rossell RI, Beverly PC, Kemshead JT, Walsh FS. Neural cell adhesion molecule (N-CAM) is the antigen recognized by monoclonal antibodies of similar specificity in small cell lung carcinoma and neuroblastoma. In $J$ Cancer 44: 573-578, 1989.

3. Sheppard MN, Marangos PI, Bloom SR, Polak JM. Neuron-specific enolase: a marker for the early 
dewelopment of nerves and endocrine cells in the human lung. Life Sci 34: 265-271, 1984.

4. Lauweryms IM, Van Rangt L, Lloyd RV, O'Connor DT. Chromogranin in bronchopulmonary neuroendoctine cells. Immunocytochemical detection in human, monkey, and pig respiratory mucosa. J Histochem Cytochem 35: 113 118, 1987

5. Wharton J, Polak IM, Bloom SR, Ghatei MA, Solcia E, Brown MR, Pearse AGE. Bombesin-like immunoreactivity in the lang. Nature 273: 769-770, 1978 .

6. Lee I, Gould VE, Moll R, Wiedenmann B, Franke WW. Synaptophysin expressed in bromchopumonary tract: neuroendocrine cells, neuroepithellal bodies and neuroendocrine neoplasms. Differentiation 34: 115-125, 1987.

7. Roebroek AJM, van de Velde HJK, Van Bokhoven A, Broers JLV, Ramaekers FCS, Van de Ven WJM. Cloning and expression of alternative transcripts of a novel neutoendocrine-specific gene and identification of its 135-kDa translational product. J Biol Chen 268: 13439-13447, 1993.

8. Kools PFJ, Roebroek AJM, van de Velde HJK, Marynen P, Bullerdiek I, Van de Ven WJM. Regional mapping of the human NSP gene to chromosome region $14 \mathrm{q} 21-\mathrm{q} 22$ by fluorescence in situ hybricization analysis. Cytogenet Cell Genet 66:48-50, 1993.

9. Van de Velde HJK, Roebroek AJM, Senden NHM, Ramaekers FCS, Van de Ven WJM. NSPencoded reticulons, neuroendocrine proteins of a novel gene family associated with membranes of the endoplasmic reticulum. J Cell Sci 107: 2403-2416, 1994.

10. Senden NHM, van de Velde HJK, Broers JLV, Timmer EDJ, Kuijpers HJH, Roebroek AJM, Van de Ven WJM, Ramaekers FCS. Subcellular localization and supramolecular organization of neuroendocrine-specific protein B (NSP-B) in small cell lung cancer. Eur J Cell Biol 65: 341-353, 1994.

11. Lytton J, Westlin M, Burk SE, Shull GE, MacLennan DH. Functional comparisons between isoforms of the sarcoplasmic or endoplasmic reticulum family of calcium pumps. I Biol Chem 267 : $14483-14489,1992$.

12. Jorgensen A, Arnold W, Pepper D, Kahl S, Mandel F, Campbell K. A monoclonal antibody to the $\mathrm{Ca}^{2+}-\mathrm{ATP}$ ase of cardiac sarcoplasmic reticulum cross-reacts with slow type I but not with fast type II canine skeletal muscle fibers: an immunocytochemical and immunochemical study. Cell Motil Cytoskel 9: 164-174, 1988.

13. Van de Velde HJK, Roebroek AJM, van Leeuwen FW, Van de Ven WJM. Molecular analysis of expression in rat brain of NSP-A, a nowel neuroendocrine-specific protein of the endoplasmic reticulum. Mol Brain Res 23: 81,-92, 1994.

14. De Leij L, Postmus PE, Buys CH, Elema JD, Ramaekers F, Poppema S, Brouwer M, Van der Veen AY, Mesander G, The HT. Characterization of three new variant type cell lines derived from small cell carcinoma of the lung. Cancer Res 45: 6024-6033, 1985.

15. Berendsen HH, De Leji L, De Vries EG, Mesander G, Mulder NH, De Jong B, Buys CH, Postmus PE, Poppena S, Sluiter HJ, The HT. Characterization of three small cell lung carcinoma cell lines established from one patient during longitudinal follow-up. Cancer Res 48: 6891-6899, 1988.

16. Bepler $\mathrm{G}$, Jaques $\mathrm{G}$, Koehler A, Gropp $C$, Havemann $K$. Markers and characteristics of human SCLC cell lines. Neuroendocrine markers, dass ical tumor markers, and chromosomall characteristics of pernanent human small cell lung cancer cell lines. J Cancer Res Clin Oncol 113:253-259, 1987.

17. Bepler $G_{a}$ Jaques $G$, Neumann $K_{s}$ Aumuller $G$, Gropp $C$, Havemann $K$. Establishment, growth properties and morphological characteristics of permanent human small cell lung cancer cell lines. J Cancer Res Clin Oncol 113:31-40, 1987.

18. Broers JLV, Mijheere EP, Klein Rot M, Schaart G, Sijlmans A, Boerman OC, Ramaekers FCS. Novel antigens characteristic of neuroendocrine malignancies. Cancer 67; 619-633, 1991 .

19. Auffry $C$, Rougeon F. Purification of mouse immunoglobulin heavy-chan messenger RNAs from total myeloma tumor RNA. Eur J Biochem 107: 303-314, 1980.

20. Sambrook J, Fritsch EF, Maniatis T. In: Molecular Cloning: A laboratory manual, 2nd Edition, Cold Spring Harbor Laboratory Press, New York, 1989.

21. Church GM, Gilbert W. Genomic sequencing. Proc Natl Acad Sci USA 81: 1991-1995, 1984.

22. Roebroek AJM, Martens GJM, Duits AJ, Schalken JA, Van Bokhoven A, Wagenaar SjSc, Van de Ven WJM. Differential expression of the gene encoding the novel pituitary polypeptide $7 \mathrm{~B} 2$ in human lung cancer cells. Cancer Res 49: 4154-4158, 1989.

23. Leammli UK. Cleavage of structural proteins during assembly of the head of bacteriophage T4. Nature $227: 680-685,1970$.

24. Van Duijnhoven JLP, Creemers JWM, Kranenborg MGC, Timmer EDJ, Groeneveld A, Van den Ouweland AMW, Roebroek AJM, Van de Ven WJM. Dewelopment and characterization of a panel of monoclonal antibodies against the novel subtilisin-like proprotein processing enzyme furin. Hybridoma 11: 71-86, 1992 . 
25. Roskams T, Van den Oord JJ, De Vos R, Desmet VJ. Neuroendocrine features of reactive bile ductules in cholestatic liver disease. Am Pathol 137: 1019-1025, 1990.

26. Skow BG, Sorensen BJ, Hirsch FR, Larsson LI, Hansen HH. Prognostic impact of histologic demonstration of chromogranin A and neuron-specific enolase in pulmonary adenocarcinoma. Ann Oncol 2: 355-360, 1991 .

27. Pujol JL, Simony J, Demoly P, Charpentier R, Laurent JC, Daures JP. Lehmann M, Guyot V, Godard P, Michel FB. Neural cell adhesion molecule and prognosis of surgically resected lung cancer. Am Rev Respir Dis 148: 1071-1075, 1993.

28. Shaw GL, Gazdar AF, Phelps R, Linnoila RI, Thde DC, Johnson BE, Oie HK, Pass HI, Steinberg SM, Ghosh BC, Walsh TE, Nesbitt JC, Cotelingham JD, Minna JD, Mulshine JL. Individualized chemotherapy for patients with non-small cell lung cancer determined by prospective identification of neuroendocrine markers and in witro drug sensitivity testing. Cancer Res 53: 5181-5187, 1993.

29. Graziano S, Kern J, Herndon J, Tatum A, Memoli V, Sugarbaker D, Skarin AT, Viallet J, Green MR. Analysis of neuroendocrine markers and P185 before and after chemotherapy in patients with stage IIIA non-small cell lung cancer: CALGB9064. Proc Am Soc Clin Oncol 13: 328, 1994.

30. Gazdar AF, Carney DN, Nau MM, Minna JD. Characterization of variant subclasses of cell lines derived from small cell lung cancer having distinctive biochemical, morphological, and growth properties. Cancer Res 45: 2924-2930, 1985. 



\title{
CHAPTER 6
}

\section{NSP-RETICULONS AS INDEPENDENT MARKERS FOR NON-SMALL CELL LUNG CANCER WTTH NEUROENDOCRINE DIFFERENTIATION}

\author{
Nicole HM Senden, R Ilona Linnoila, Erika DJ Timmer, \\ Helgi JK van de Velde, Anton JM Roebroek, Wim JM Van de Ven, \\ Jos LV Broers, Frans CS Ramaekers
}

\section{Submitted}

\begin{abstract}
NSP-reticulons have recently been discovered and were shown to exhibit a neuroendocrine-specific expression pattern. These protein aggregates are anchored to the membranes of the endoplasmic reticulum (ER) of small cell lung cancer (SCLC), but not of non-SCLC cells. In the current study we have examined the occurrence of NSP-reticulons in the non-SCLC cell lines NCI-H460, NCI-H810 and NCI-H1155, known to express neuroendocrine (NE) features (non-SCLC-NE) and showing a growth morphology inbetween that of SCLC and non-SCLC. NSP-reticulon expression was observed in all three non-SCLC-NE cell lines using the immunofluorescence assay, albeit with variable intensity and in a varying number of cells. Western and Northern blot analysis confirmed the presence of NSP-reticulon expression in these non-SCLCNE cell lines, and showed that they were predominantly of the NSP-A type. When compared to the expression patterns of conventional NE markers, NSP-reticulons revealed a distinct staining profile, showing only partial overlap with the other markers. Electron microscopy revealed clusters of dense core vesicles (DCVs) in two of these cell lines. These phenotypes are similar to the patterns found in typical SCLC cell lines, while typical non-SCLC cultures did not express these markers. However, the non-SCLC-NE cell lines combined these NE characteristics with some features of non-SCLC. We conclude that NSP-reticulon expression is restricted to lung carcinoma cells with a NE phenotype and predict that these constituents may become clinically relevant markers for detection of NE differentiation in solid tumors.
\end{abstract}




\section{INTRODUCTION}

It is of clinical importance to distinguish lung cancers into SCLC and non-SCLC because of differences in therapeutic response and prognosis $[1,2]$. However, it is well accepted that carcinoma of the lung may arise from a pluripotent epithelial cell resulting in the accurrence of a variety of phenotypes within one lung carcinoma subtype [3]. In recent years, warious groups have reported that a subset of 10-20\% of histologically non-SCLC, particularly adenocarcinoma, express a variety of NE markers, such as L-dopa decarboxylase (DDC), neuron-specific enolase (NSE), chromogranin A, synaptophysin, neural cell adhesion molecule (NCAM) and Leu-7 [49]. Patients presenting with non-SCLC containing NE characteristics (non-SCLC-NE) may exhibit different clinical behaviour as compared to patients with non-SCLC without these properties, including responsiveness to chemotherapy [10-12].

NSP-reticulons have recently been described to be novel indicators of NE tumor cells of the lung [13] and were identified as a novel cluster of NE markers during the Third International IASLC Workshop on Lung Tumor and Differentiation Antigens [14]. The protein family of NSP-reticulons is encoded by a single gene and associated with the endoplasmic reticulum (ER) [15-17]. Expression of the gene results in three transcripts of $3.4,2.3$ and $1.8 \mathrm{~kb}$, consisting of common 3 '-end and unique 5 '-sequences. These give rise to NSP-A (135 kDa), NSP-B $(45 \mathrm{kDa})$ and NSP-C $(23 \mathrm{kDa})$, respectively. NSP-A mRNA has been found in 14 out of 18 SCLC cell lines, while NSP-C has been detected in 16 out of 18 cell lines [13]. NSP-B has until now only been found in the SCLC cell line NCI-H82 [15]. In accord, the immunohistochemical study in solid lung tumors revealed expression of NSP-A in most of the SCLC and carcinoids, whereas non-SCLC tumors were negative. Interestingly, a group of non-SCLC-NE tumors showed NSP-A expression [13].

The study of lung cancer cell lines can provide more insight into the molecular basis of the phenotypic diversity of lung cancer subtypes because they in general retain many characteristics of the in vivo cancers. Next to cell cultures with the typical SCLC and non-SCLC phenotypes, several cell lines have been established from non-SCLC tumors that show a combined phenotype, i.e. NE markers present in cells with non-SCLC morphology. In the present study we compared the expression profiles of NSPreticulons in three non-SCLC-NE cell lines in relation to conventional NE markers, and examined to what extent these NE markers co-occur next to non-SCLC characteristics.

\section{MATERIALS AND METHODS}

\section{Lung cancer cell lines}

Human lung cancer cell lines used in this study included the non-SCLC-NE cell lines NCI-H460, NCI-810, NCI-H1155 derived from large cell lung carcinomas (LCLC) $[18,19]$, cell line LCLC-103H [20] also derived from a LCLC, and the adenocarcinoma cell line NCI-H125 [18]. Furthermore, the classic SCLC (SCLC-C) cell line NCI$\mathrm{H} 69$ and the variant SCLC (SCLC-V) cell line NCI-H82 were used for comparison $(21,22)$. All cell lines were cultured as described before $(23)$. 
Electron microscopy.

The methodology for transmission electron microscopy is described elsewhere [5]. Briefly, cell pellets were fixed in $2 \%$ glutaraldehyde in $0.1 \mathrm{M}$ cacodylate for $1 \mathrm{~h}$, dehydrated in graded ethanols, and embedded in epoxy resin. Thin sections were stained with uranyl acetate and lead citrate and examined with a JEOL $100 \mathrm{CX}$ electron microscope.

\section{L-Dopa Decarboxylase assay}

DDC assays were performed as described before [5]. Freshly prepared cell homogenates were clarified and frozen at $-70^{\circ} \mathrm{C}$ until analysis. One unit of enzyme activity was defined as $1 \mathrm{nmol}$ of ${ }^{14} \mathrm{CO}_{2} / \mathrm{h}$. For cell line LCLC-103H the DDC activity was deduced from ref. 20 .

\section{Antibodies}

Antibodies to conventional NE markers. Mouse monoclonal antibody (mab) RNL- $\Perp$ (IgGl) recognizing NCAM [24], used as undiluted culture supernatant for immunofluorescence; a polyclonal rabbit antiserum to synaptophysin (DAKO A/S, Glostrup, Denmark), diluted 1:50 for immunofluoresence; mouse mab LK2H10 to chromogranin A (IgGl), available from BioGenex (San Ramon, Ca, USA), dilluted 1:100 both for immunofluorescence and for radioimmunoassays; mouse mab HNK-1 (IgM), recognizing Leu-7, an antigen expressed by natural killer cells, as well as nerves and most normal and malignant NE cells, including SCLC $[25,26]$. This antibody was obtained from Becton Dickinson (Mountain View, Ca, USA) and diluted 1:10 for immunofluorescence; polyclonal rabbit antiserum to NSE available from Accurate Chemical Westbury (NY, USA) and diluted 1:1000 for radioimmunoassays; polyclonal rabbit antiserum to calcitonin [27], kindly provided by Dr. K. Becker (Washington D.C., USA), diluted 1:5000 for radioimmunoassays.

Anibodies to intermediate filament proteins (IFP). All IFP antibodies were mouse mabs and only used for immunofluorescence studies. RCK 102 (GGl), which recognizes cytokeratins 5 and 8 and therefore reacts with virtually all epithelial tissues [27], used as undiluted culture supernatant. The antibody recognizes only cytokeratin 8 in the cell lines examined; $\mathbb{R C K} 105$ (IgGI) reactive with cytokeratin 7 , present in a subgroup of glandular epithelia including adenocarcinoma of the lung, but absent in SCLC $[28,29]$, used as undiluted culture supernatant; MNF (IgGl) reactive with the 68 $\mathrm{kDa}$ and $200 \mathrm{kDa}$ neurofilament subunits 30 , diluted $1: 10$, available from EuroDiagnostica BV (Apeldoorn, The Netherlands); RNF403 (IgG1) reactive with the 160 $\mathrm{kDa}$ neurofilament subunit (Tonnaer ELGM et al., The distribution of neurofilament proteins in the inner ear of the rat during ontogenesis. In preparation), used as undiluted culture supernatant; $41 \mathrm{CC} 4$ (IgM) directed to lamin A and lamin C, kindly provided by Dr. G. Warren (Heidelberg, Germany) [31], used as undiluted culture supernatant, R27 (IgM) reactive with lamins A and C. This antibody was a gift from Dr. G. Krohne (Heidelberg, Germany) [32], used as undiluted cuilture supernatant; 133 A2 (IgG3) reactive only with lamin A [33], kindly provided by Dr Y. Raymond (Montreal, Canada), mouse ascites diluted $1: 2500 ; 119 \mathrm{D5}$ (IgG1) reactive with lamin $\mathrm{B} 1$, kindly provided by Dr. Y. Raymond, mouse ascites diluted 1:500; LN43 directed 
against lamin B2 (34), kindly provided by Dr. E. B. Lane (Dundee, UK), used as undiluted culture supernatant.

Antibodies to NSP-reticulons. Mouse mabs MON-160, MON-161 and MON-162 (IgG1), recognizing specifically NSP-A and used as a 1:1:1 culture supernatant mix (MON160-162) [15, 16,35]. This mix was used undiluted for immunofluorescence and 1:5 for immunoblotting; mouse mabs RNL-2 and RNL-3 (IgGl), which were raised against the SCLC cell line NCl-H82, recognizing epitopes in NSP-A and NSP-B $[17,24,36]$. These antibodies were used as undiluted culture supernatants for immunofluorescence, and in a 1:100 dilution for immunoblotting; mouse mab RNL-4 (IgG1), raised against a synthetic peptide encompassing the unique twenty amino-terminal amino acids of NSP-C [37]. The antibody was used as undiluted culture supernatant for immunofluorescence; polyclonal rabbit antiserum POL-1, recognizing epitopes present in NSP-A and in NSP-B $(16,35,36)$, used 1:100 for immunofluorescence and 1:500 for immunobloting.

\section{Radioimmunoassays.}

Radioimmunoassays for NSE, chromogranin A and calcitonin were performed and evaluated as described $[21,38]$. For cell line LCLC-103H the NSE concentration was deduced from ref. 20 .

\section{Indirect immunofluorescence microscopy}

The procedure for the application of the indirect immunofluorescence technique has been described [17]. In brief, floating cells were placed on glass slides using cytocentrifugation, while cells which grow as adherent cultures, were detached with $0.125 \%$ trypsin (Difco Laboratories, Detroit, USA), 0.02\% EDTA and $0.02 \%$ glucose (Merck) in PBS, pH 7.4 and allowed to grow on glass cover slips for 1-2 days. All cells were fixed by dipping in methanol for $5 \sec \left(-20^{\circ} \mathrm{C}\right)$, followed by 3 times in acetone (Merck) for $5 \sec \left(4^{\circ} \mathrm{C}\right)$. Subsequently, the cells were incubated for $1 \mathrm{~h}$ with the primary antibody diluted in PBS, and thereafter washed in PBS. As secondary antibodies, either fluorescein isothiocyanate (FITC)-conjugated rabbit anti-mouse Immunoglobulins (Ig; 1:100; DAKO A/S) or Texas Red-conjugated goat anti-rabbit Ig (1:80; Southern Biotechnology Association, Inc. (SBA), Birmingham, USA) were used. In the double-label immunofluorescence technique a mixture of two primary antibodies was applied in the first step and after washing with PBS, a mixture of FITC-conjugated goat anti-mouse $\operatorname{Ig}(1: 25 ; \mathrm{DAK} 0 \mathrm{~A} / \mathrm{S})$ and Texas Red-conjugated goat anti-rabbit Ig was added. DNA was stained by 4,6-diamidino-2-phenyl-indole (DAPI; Sigma, St.Louis, MO, USA). After washing with PBS the cells were mounted in $90 \%$ glycerol in $0.2 \mathrm{M}$ Tris- $\mathrm{HCl}$, pH 8.0 with addition of $2 \% 1,4$-diazobicyclo-[2,2,2]octane (DABCO; Merck) and $0.02 \%$ sodium-azide (Merck). As negative controls the primary antibody was replaced by PBS or by a non-relevant antiserum. Slides were viewed with a Zeiss Axiophot microscope (Zeiss, Oberkochen, Germany). Photographs were made using a 400 ASA Tri-X film (Kodak).

\section{Gel electrophoresis and immunoblotting}

For gel electrophoresis, immunoblotting and sample preparation the same procedures were followed as described before [17]. 


\section{RNA in situ hybridization.}

For RNA in situ hybridization of SP-A and Clara cell protein the procedures were followed as described [39-40].

\section{RNA isolation and Northern blot analysis}

Total RNA was isolated from cultured lung cancer cells by guanidine thiocyanate/cesium chloride gradient centrifugation [41]. RNA was denaturated and $20 \mu \mathrm{g}$ was size-fractionated on a $1 \%$ agarose formaldehyde gel, blotted to $\mathrm{Hybond} \mathrm{N}+$ filters (Amersham, Buckinghamshire, UK) and hybridized with the NSP CDNA insert of pAB124 [15]. This probe was radiolabelled by random priming [42]. The amount of total RNA loaded onto each lane was checked by optical density reading at 260 and $280 \mathrm{~nm}$ and confirmed by ethidium bromide staining of the agarose gel.

\section{RESULTS}

\section{Growth morphology}

Both SCLC cell lines NCI-H82 and NCI-H69 grow as floating aggregates with occasional adherence to the culture flask of NCI-H82 cells, whereas the non-SCLC cell lines $\mathrm{LCLC}-103 \mathrm{H}$ and $\mathrm{NCI}-\mathrm{H} 125$ grow as adherent cells. Interestingly, the three examined non-SCLC-NE cell lines show intermediate growth patterns, i.e. NCI-H460 grows as an adherent monolayer, NCI-H1155 grows in loosely organized aggregates with a tendency of adherence to the culture flask and NCI-H810 grows as more tight clusters partially adhering to the culture flask.

\section{Phenotyping}

The expression patterns of the differentiation markers tested in the lung carcinoma cell lines are summarized in Table 1 . The results of the immunofluorescence studies are furthermore depicted in Figures 1-3. The differentiation characteristics of the two SCLC cell lines have been extensively described and are used here as reference cell lines for NE differentiation. The same holds true for the two non-SCLC cell lines LCLC-103H and NCI-H125, which serve as reference for non-NE differentiation [18$24,43)$. For comparison, several data were extracted from these references and included in Table 1.

Expression of NSP-reticulons. In both SCLC cell lines NSP-A is present, i.e. in NCI$\mathrm{H} 82$ in most cells and in NCI-H69 in part of the cells. NSP-C immunofluorescence results were negative in both SCLC cell lines. In the non-SCLC cell lines LCLC-103H and NCI-H125 no expression of NSP-A or NSP-C could be found. NSP-A expression was observed in all non-SCLC-NE cell lines. In most cells of the adherent cell line NCI-H460 the typical ER staining pattern of NSP-A could be observed (Fig. $1 \mathrm{~g}-\mathrm{i}$ ). In this cell line NSP-C expression is not found. In NCI-H810 most cells showed variable expression of NSP-A (Fig. 2 b,e,h) as a reticular staining pattern in the cytoplasm. NSP-C was detectable in this cell line, with a striking immunoreactivity in the extensions of the cells (see Fig 5, chapter 4). In NCI-H1155, a strong positive staining reaction for NSP-A was observed in a considerable fraction of the cells, whereas the other cells showed a weak reaction or negative reaction (Fig $3 \mathrm{~b}, \mathrm{~d}, \mathrm{f}, \mathrm{h}, \mathrm{l}$ ). 
Table 1.

Phenotyping of lung cancer cell lines.

\begin{tabular}{|c|c|c|c|c|c|c|c|}
\hline Cell line & $\mathrm{NClHO2}$ & NCIMH69 & LCLC-103H & NCL-H125 & $\mathrm{NCH}-\mathrm{H} 460$ & $\mathrm{MCl}-\mathrm{H} 810$ & NCl-R⿴囗1 155 \\
\hline Type & $\$ C L C-V$ & SCLC-C & mon-SCLC & non-SCLC & $\begin{array}{l}\text { nonk } \\
\text { SCLC-NE }\end{array}$ & $\begin{array}{l}\text { non- } \\
\text { SCLC-NE }\end{array}$ & $\begin{array}{l}\text { non-SCLC- } \\
N E\end{array}$ \\
\hline Origin & $\begin{array}{l}\text { plecural } \\
\text { effusion }\end{array}$ & $\begin{array}{l}\text { plewral } \\
\text { effusion }\end{array}$ & $\begin{array}{l}\text { pleural } \\
\text { effusion }\end{array}$ & $\begin{array}{l}\text { solid lung } \\
\text { tumor }\end{array}$ & $\begin{array}{l}\text { pleural } \\
\text { effusion }\end{array}$ & $\begin{array}{l}\text { solid lung } \\
\text { tumor }\end{array}$ & $\begin{array}{l}\text { mediastinal } \\
\text { broncho- } \\
\text { scopy }\end{array}$ \\
\hline Histology & $\begin{array}{l}\text { small cell/ } \\
\text { large cell }\end{array}$ & small cell & $\begin{array}{l}\text { large cell } \\
\text { with giant } \\
\text { cells }\end{array}$ & $\begin{array}{l}\text { adeno- } \\
\text { squamous }\end{array}$ & large cell & large cell & large cell \\
\hline $\begin{array}{l}\text { Growth } \\
\text { marpholiagy }\end{array}$ & $\begin{array}{l}\text { flosting, } \\
\text { partly } \\
\text { adhering }\end{array}$ & floating & adthering & adhering & adhering & $\begin{array}{l}\text { foating, } \\
\text { partly, } \\
\text { adhering }\end{array}$ & $\begin{array}{l}\text { floating, } \\
\text { partly" } \\
\text { adhering }\end{array}$ \\
\hline EM/DCV & $\begin{array}{l}\text { occassionally } \\
2-3 \text { smail } \\
\text { DCVs }\end{array}$ & present & nd & none & $\begin{array}{l}\text { rare or } \\
\text { mone }\end{array}$ & $\begin{array}{l}\text { clusters of } \\
\text { variable } \\
\text { size } \\
\text { DCVs }\end{array}$ & $\begin{array}{l}\text { clusters of } \\
\text { simall } \\
\text { DCVs }\end{array}$ \\
\hline $\begin{array}{l}\text { DDC } \\
(U / \mathrm{mg})\end{array}$ & 0.6 & 149 & $<0.1$ & 0 & 0 & 700 & 283 \\
\hline $\begin{array}{l}\text { NSE (ng/mg } \\
\text { proi) }\end{array}$ & 317 & 817 & 286 & 21 & 4357 & 480 & 726 \\
\hline $\begin{array}{l}\text { CgA (ng/mg } \\
\text { prot) }\end{array}$ & $\operatorname{neg}(39)$ & pos $(370)$ & neg & $\operatorname{neg}(<4)$ & neg & pos $(706)$ & neg (89) \\
\hline Syn & neg & neg & neg & neg & neg & neg & pos \\
\hline NCAM & pos. & pos & neg & neg & poss & pos. & pos \\
\hline Leu-7 & neg & pos & neg & neg & neg & neg & pos. \\
\hline $\begin{array}{l}\text { Calcitonin } \\
\text { (ng/mg prot) }\end{array}$ & neg & $<4$ & nd & neg & neg & 1.44 & 176 \\
\hline SP-A $\mathrm{A}$ RNA & neg & neg & nid & neg & neg & neg & pos \\
\hline $\begin{array}{l}\text { Clara cell } \\
\text { protein } \\
\text { mRNA }\end{array}$ & nd & nd & nd & nd & nd & neg & neg. \\
\hline$N F 68 / 200$ & pos & neg & negg & neg & pos & neg & pos \\
\hline NF 160 & pos & neg & neg & neg & $\operatorname{neg}$ & pos & pos \\
\hline CK 5.9 & negg & post & pos: & poss & pos & pos & pos \\
\hline $\mathrm{CK} 7$ & neg & neg & naeg & poss & neg & pos & neg \\
\hline Vimentin & pas: & negs & pos & pos & pos & neg & pos \\
\hline Lamin AdC & neg & neg & pos & pos: & poss & pos & pos \\
\hline Lamin $\mathrm{A}$ & neg & neg. & pos & pos & pos & pos & pos \\
\hline Lamin BI & pos & pos & pos & pos & pos & pos & pos \\
\hline Lamin $B 2$ & pos & pos & pos & pos & poss & pos & pos \\
\hline $\mathrm{NSP}-\mathrm{A}$ & pos & pos & neg & neg & poss & pos & pos \\
\hline NSP-B & pos & neg & neg. & neg & neg & neg & neg \\
\hline NSP $-C$ & neg & neg & neg & neg & neg & pos & pos \\
\hline
\end{tabular}

- Abbreviations used: SCLC-V, wariant type small cell lung cancer; SCLC-C, classic type SCLC; non-SCLC-NE, non-SCLC with neuroendocrine features, EM, electron microscopy; DCV, dense core vesicle; DDC, L-dopa decarboxylase; $N$ SE, neuron-specific enolase; CgA, chromogranin A; Syn, symaptophysin; NCAM, neural cell adhesion molecule; SP-A, surfactant protein-A; NF, neurofilament; $C K$, cytokeratin; nd, not done. 
NSP-C expression was observed in this cell line in a smaller fraction of cells as compared to NSP-A (see Fig 5, chapter 4). Immunoblots of lysates of the non-SCLCNE cell lines NCI-H810, NCI-HI155 and NCI-H460, incubated with polyclonal antibody POL-1 showed a strong reaction with NSP-A at the expected Mw of $135 \mathrm{kDa}$ in the cell lines (Fig. 4, lanes 1-3). In the adenocarcinoma cell line NCI-H125 no NSP-A could be detected (Fig. 4, lane 4). In the SCLC cell line NCI-H82 both NSP-A and NSP-B (45 kDa) could be seen (Fig. 4, lane 5). However, after incubation with a mixture of antibodies MON 160-162 only a reaction with NSP-A was seen in all three non-SCLC-NE cell lines as well as in the SCLC cell line NCI-H82 (Fig. 4, lanes 6-9). In NCl-H810 only a faint $135 \mathrm{kDa}$ band was detected (Fig. 4, lane 7). Probably due to the low number of cells expressing NSP-C immunoblot analyses for this protein were negative in the cell lines described in Table 1 . Northern blot analysis of the nonSCLC-NE cell lines NCI-H460 and NCI-H1155 revealed a 3.4-kilobase transcript encoding NSP-A (Fig. 5, lanes 1,2). In accord with the immunoblotting results the 1.8 $\mathrm{kb}$ transcript, encoding NSP-C, was not detectable in these two cell lines. In the control cell line NCI-H82 transcripts of 3.4 and $2.3 \mathrm{~kb}$, encoding NSP-A and NSP-B, respectively, were detected (Fig. 5, lane 3). In the non-SCLC cell lines no NSP transcripts were observed (see ref. 13).

Conventional NE markers. In the two SCLC cell lines the different NE markers could be detected to a variable extent. In the SCLC-V cell line NCI-H82 no DDC activity was detected in contrast to a considerable level found in the SCLC-C cell line NCIH69 [5]. NSE could be detected in both SCLC cell lines. EM-studies show that NCIH69 cells contain dense core vesicles (DCVs), while occassionaly some small DCVs were detected in NCI-H82 [5]. Proteins which expression is correlated with DCVs such as chromogranin $A$ and synaptophysin were assayed, and in NCI-H69, part of the cells express chromogranin $\mathrm{A}$ as detected by immunofluorescence and by radioimmunoassay [36]. Synaptophysin expression could not be detected in this cell line. In contrast, NCI-H82 did not express synaptophysin and low levels of chromogranin A were only detectable by radioimmunoassay [38]. NCI-H82 showed no Leu-7 expression, whereas in NCI-H69 Leu-7 was present in part of the cells. In both SCLC cell lines NCAM expression was observed, while calcitonin was not present in the SCLC cell lines. In the non-SCLC cell line LCLC-103H and in the adenocarcinoma cell line NCl-H125 no NE differentiation markers could be found, except for a low level of NSE expression in LCLC-103 [20]. In the non-SCLC-NE cell lines variable levels of DDC-activity were measured ranging from no detectable levels in $\mathrm{NCl}-\mathrm{H} 460$ to moderate and high levels in NCI-H1155 and NCI-H810, respectively. High NSE levels were found in NCI-H460, while NCI-H810 and NCI-H1 155 contained moderate levels. DCVs were not often found in NCI-H460, but clusters of variable size DCVs were found in NCI-H810 and clusters of small DCVs in NCI-H1155. Concordantly, no chromogranin A or synaptophysin expression was observed in NCI-H460. In NCIH810 chromogranin A was found to be expressed in some cells (Fig. 2a), while synaptophysin expression was not present. In NCI-H1155 chromogranin A expression could not be detected, but synaptophysin was present in this cell line (Fig. 3a) and Leu-7 expression could be detected in some cells of this cell line (Fig. 3c). Leu-7 was not found in the other two cell lines. However, NCAM expression was present in all three cell lines, i.e. in almost all cells of NCI-H810 (Fig. 2d) and in a considerable 


\section{Chapter 6}

part of the cells of NCI-H460 (Fig. la) and NCI-HI155 (Fig. 3e). Calcitonin was found in the cell lines NCI-H810 and NCI-H1155.
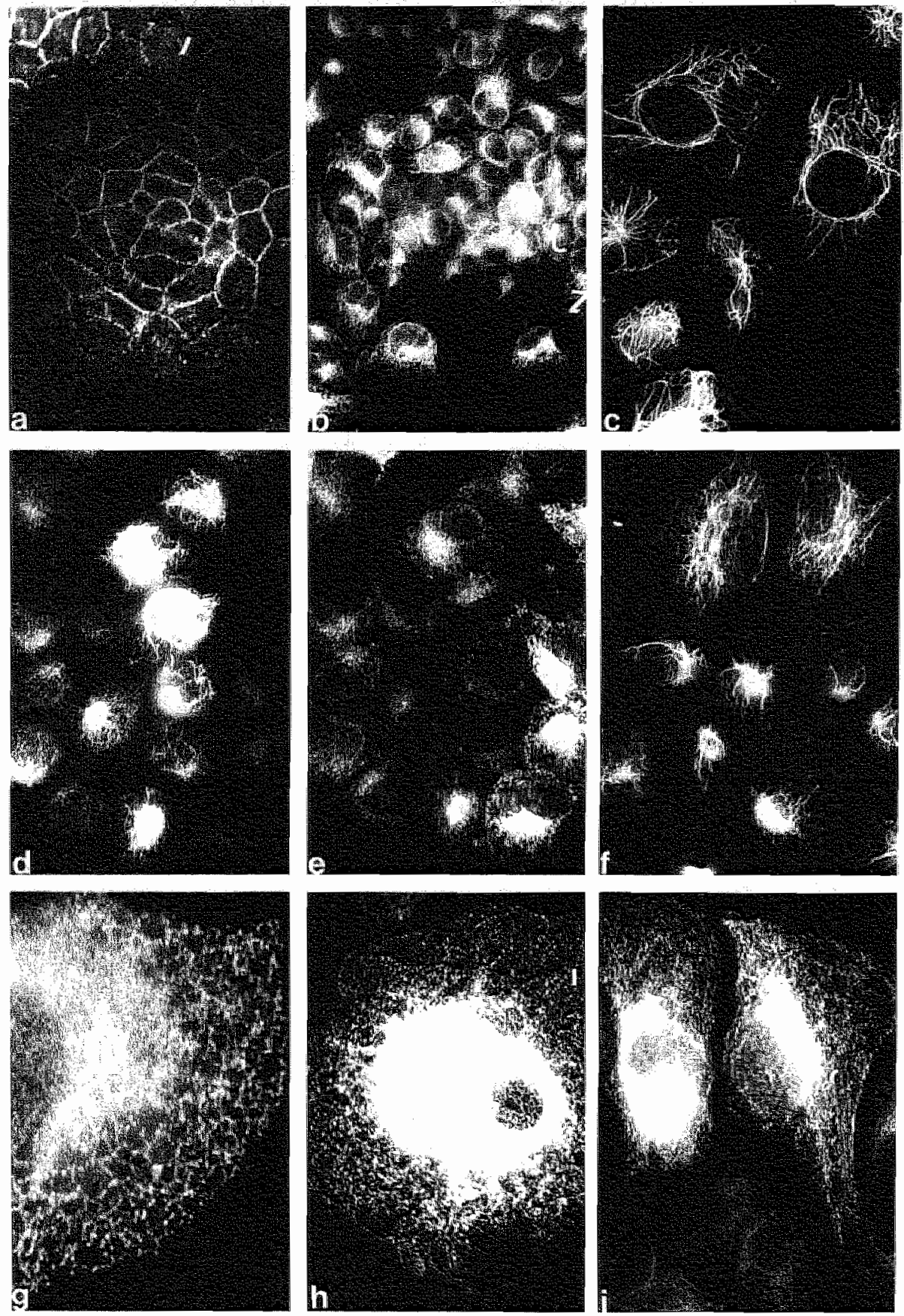
Non-SCLC differentiation markers. Surfactant protein-A (SP-A) mRNA could not be detected in the SCLC cell lines or in the non-SCLC cell line NCI-HL25 [44]. Amongst the non-SCLC-NE cell lines SP-A was only present in NCI-H1155. Clara cell protein mRNA was not detectable in the non-SCLC-NE cell lines. In the SCLC-V cell line NCI-H82 no cytokeratins, but neurofilament proteins and vimentin were present [24]. In SCLC-C cell line NCI-H69 cytokeratin 8 but not cytokeratin 7 was found, while neurofilaments or vimentin were also absent (see also 24). Both SCLC cell lines were found to express B-type lamins in virtually all of the cells, but were negative for Atype lamins (see also 43). In both non-SCLC cell lines NCI-H125 and LCLC-103H cytokeratin 8 , typical of glandular epithelia is present. In addition the adenocarcinoma cell line NCI-H125 shows the presence of cytokeratin 7 which is characteristic of lung adenocarcinoma. Both cell lines also express vimentin in most of the cells, while NF could not be observed in either cell line. A-type and B-type lamins were present in all cells of both cell lines. When non-SCLC-NE cell lines were examined for intermediate filament protein expression neurofilaments could be detected in part of the cells of NCI-H460 with the MNF-antibody (Fig. 1d), whereas most of the NCl-H460 cells express cytokeratin 8 and vimentin (Fig. $1 \mathrm{c}$ and $1 \mathrm{f}$ ). Also A-type and B-type lamins were strongly expressed. In NCI-H810 neurofilaments were found to be expressed in part of the cells with the NF 160 antiserum, which gave a filamentous pattern in some cells, but showed a dot-like staining reaction in most of the neurofilament-positive cells (Fig. 2g, compare ref. 24). Cytokeratin 8 was found in a considerable fraction of $\mathrm{NCI}$ H810 cells (Fig. 2c), while cytokeratin 7 was also detected, but to a lesser extent (Fig. 26). Vimentin was absent. A-type lamin expression in this cell line varied from a strong perinuclear staining to a reduced and even negative reaction in part of the cells (Fig. 2i). Lamin B1 expression was also reduced in part of the cells of this cell line. In the cell line NCI-H1155 neurofilament proteins, cytokeratin 8 and vimentin were present (Fig. $3 \mathrm{~g}, 3 \mathrm{i}$ and $3 \mathrm{j}$ ). A similar pattern of A-type lamin expression as described for NCI-H810 was observed in this cell line (Fig. 3k). B-type lamins were strongly present in all cells.

\section{Coexpression of NSP-reticulons and conventional differentiation markers}

The degree of concordance of expression of NSP-A and other differentiation markers was studied by using the double immunofluorescence technique. In all three nonSCLC-NE cell lines unique combinations of the different markers tested were detected. In general, only a partial overlap of NSP-reactivity with any of the conventional NE markers was seen in the three cell lines at the individual cell level.

Figure 1. Marker expression in non-SCLC-NE cell line NCI-H 460 as detected by the indirect immunofluorescence technique. Double-label immunofluorescence studies show that in the majority of the cells NCAM, as detected with antibody RNL-1 (a, 400$)$ is coexpressed with NSP-A, as detected with polyclonal antibody POL-1 $(h, x 400)$. A strong filamentous cytokeratin 8 reaction pattern is seen in almost all cells with antibody RCK $102(\mathrm{c}, x 750)$.

Double label immunofluorescence studies indicate that neurofilaments are detected in at part of these cells with antibody MNF (d, x800), while these cells show a weak reaction with POL $1(e, \times 800)$. In almost all cells vimentin is present, showing a strong filamentous staining pattern with antibody RV202 (f, x750). In the larger, solitary cells a strong endoplasmic reticulum staining is observed with polyclonal antibody POL-1 $(\mathrm{g}, \times 2000)$, antibody RNL-3 $(\mathrm{h}, \mathrm{x} 1000)$ and antibodies MON $160-162(\mathrm{l}$, $\times 875)$ 

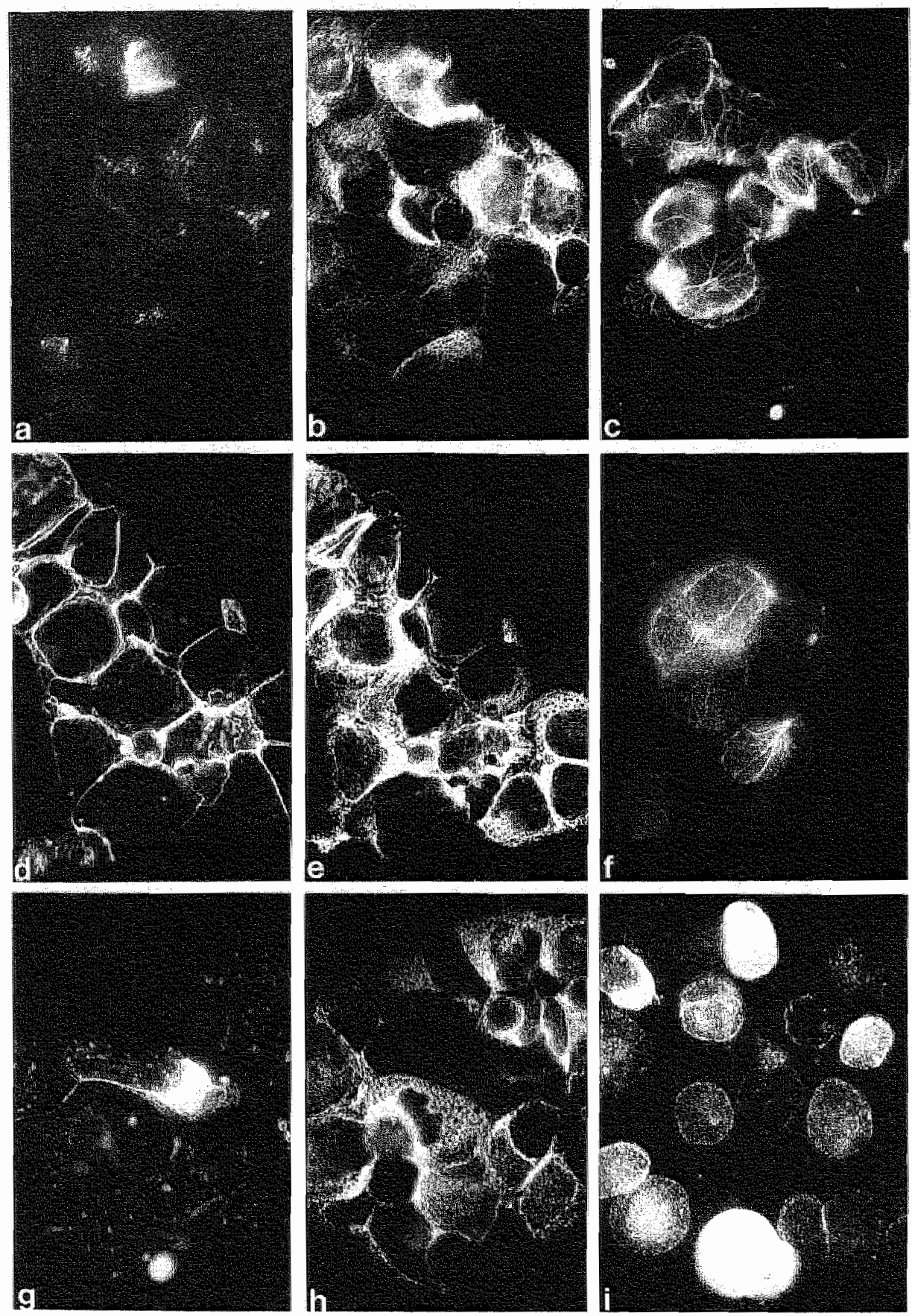
Cells positive for NSP-A were found to be either positive or negative for the other NE markers, and vice versa. Coexpression of chromogranin A and NSP-A, in the same cells, was only seen in the cell line NCI-H810, with different subcellular localizations for both antigens. However, many cells positive for NSP-A were negative for chromogranin A, while the reverse did not seem to occur (Figs. 2a and 2b). Most synaptophysin positive NCI-H1155 cells were also positive for NSP-A, but synaptophysin could also be expressed independently of NSP-A (Figs. 3a and 3b). Next to a coexpression of the Leu-7 antigen and NSP-A in these cells, also cells expressing only one of the two were found (Figs. $3 \mathrm{c}$ and $3 \mathrm{~d}$ ). In all three non-SCLCNE cell lines coexpression of NSP-A and NCAM could be observed (Figs. $2 \mathrm{~d}$ and $2 \mathrm{e}$ ), while these markers could also be present independently (Figs. 1a and $1 \mathrm{~b}$; Figs. 3e and $3 f$ ). In the three cell lines coexpression of NSP-A and neurofilaments could be seen (Figs. $3 \mathrm{~g}$ and $3 \mathrm{~h}$ ) at the cellular level, although the number of neurofilament positive cells was always less than the NSP-A positive cells. Often, strongly NSP-A positive cells were negative or only weakly positive for neurofilaments (Figs. Id and 1e), in particular in NCI-H460 in the larger, solitary growing cells. In these cells cytokeratin 8 and vimentin were detected. In cell line NCI-H810 the several strongly neurofilament positive cells seemed to be only weakly positive or negative for NSP-A (Figs. $2 \mathrm{~g}$ and 2h). No consistent correlation between the lamin expression patterns and NSP-A staining was noticeable (Figs. $3 \mathrm{k}$ and 31 ).

\section{DISCUSSION}

\section{NSP-reticulons as NE markers in lung cancer}

In previous studies NSP-gene expression was studied at the RNA and protein level in human lung tumors as well as in cell lines derived from different lung tumor types $[13,15-17,24,36)$. These studies revealed a differential expression of NSP-reticulons in NE lung tumor cells versus non-NE lung tumor cells. Typical non-SCLC (60 cases tested) and non-SCLC cell lines (17 human cell lines tested) showed wirtually no NSPgene expression $[13,24]$ while most cases of typical SCLC $(15$ cases tested) and carcinoids (8 cases tested) did express NSP-A [13,24]. Of the 18 human SCLC cell lines tested, only one cell line lacked NSP-gene transcripts [13].

Figure 2. Expression of differentiation markers in non-SCLC-NE cell line NCI-H810 as detected by the immunofluorescence technique. Double-label immunotluorescence studies show that in part of the cells chromogranin A (a, $x 750$ ) colocalizes with $\mathrm{NSP}-\mathrm{A}$, as detected with POL -1 (b, $x 750$ ). In almost all cells cytokeratin 8 is observed as detected with RCK $102(c, x 1000)$. Staining with antibody RNL-1 shows that NCAM is present in almose all cells $(d, \times 750)$, which also contain NSP $\times$, as seen with antibody $\mathrm{POL}-1(\mathrm{e}, \mathrm{x} 750$ ). In a small part of the cells, about $10-20 \%$, cylokeratin 7 is present, as monitored with antibody RCK 105 (f, $\times 1000)$. In some cells neurofilaments are observed with antibody RNF403, showing a filamentous pattern in some cells while in most cells a dot-like reaction pattern is seen $(\mathrm{g}, \times 750)$. Sometimes, in cells expressing these filamentous reurofilaments no NSP-A, is present, as seen with antibody POL-1 in a double labelling study (h, x750). A strong perinuclear staining with antibody R27 to A-type lamins is present in a part of the cells, while in some cells the A-type lamin expression is decreased or even absent (i, $x 1000)$. 

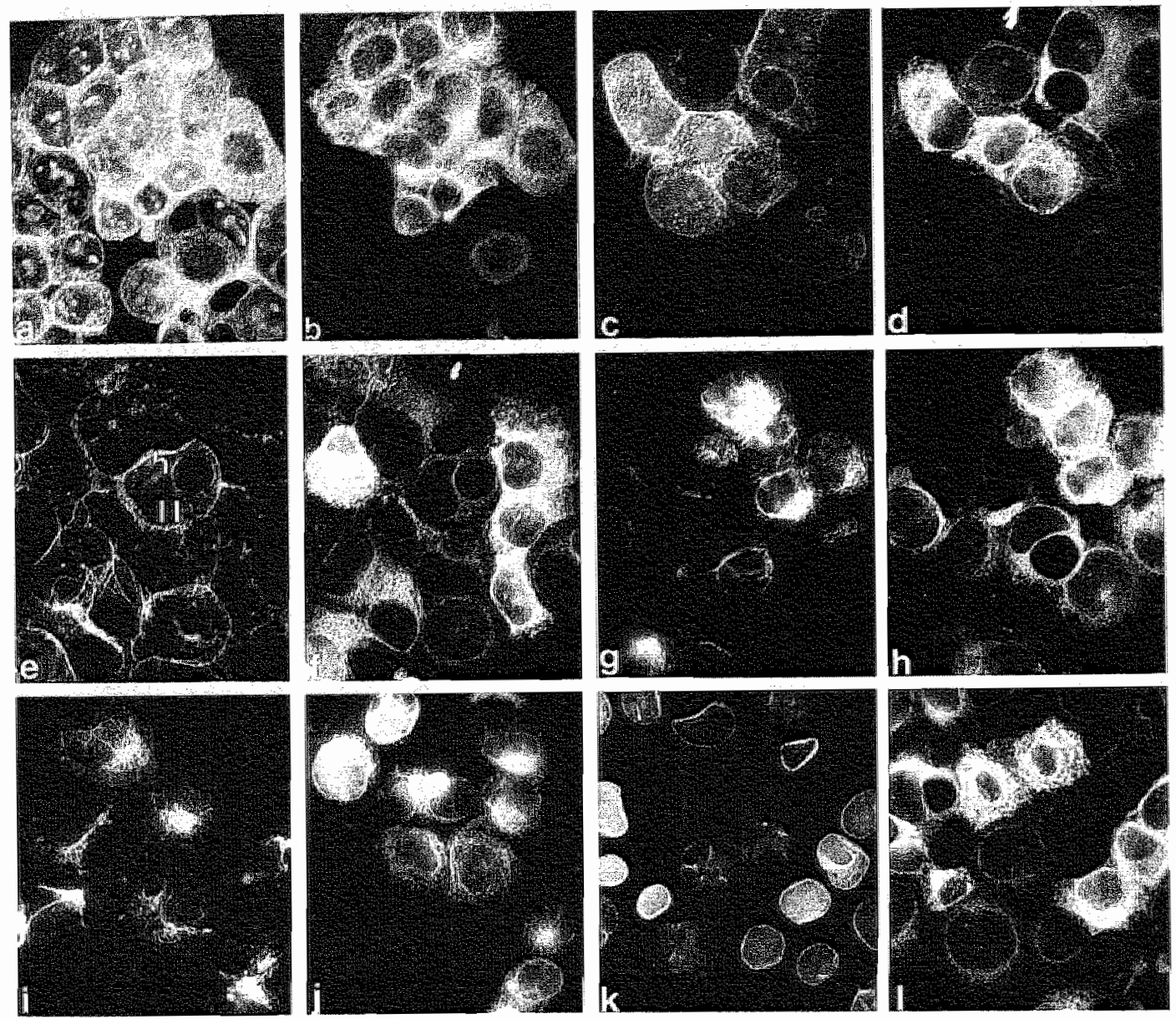

Figure 3. Expression of differentiation markers in non-SCLC-NE cell line NCI-H 1155 as detected by the immunofluorescence technique. Double-label immunofluoresence studies show that allmost all cells express synaptophysin (a), which are partly positive for NSP-A as detected by antibodies MON 160162 (b). A membranous and somatimes granular cytoplasmic reaction is seen with the antibody to Leu7 (c), with a concordant expression of NSP-A in part of the cells (d). NCAM, as detected with RNL-1 is present in most cells (e), while in these cells NSP-A is present in variable intensities (f). Neurofilaments, as detected with antibody MNF are present in about half of the cells $(\mathrm{g})$. In these cells also a strong staining with POL- 1 for NSP-A may be detected (h). Cytokeratin 8 , monitored by $\mathbb{R C K}$ 102 (i) and vimentin detected by RV 202 (i) are present in almost all cells. Antibody 41 CC4 shows next to a strong expression of A-type lamins a reduced expression in part of the cells and even A-type lamin negative cells ( $k$ ). No consistent correlation with NSP-expression can be found (1).

Magnification of all photographs is $\times 650$.

Interestingly, in lung cancer specimens, a group of non-SCLCs with NE properties showed also NSP positivity, suggesting that antibodies to NSP-reticulons might be useful for the detection of NE differentiation in mon-SCLC [13]. 


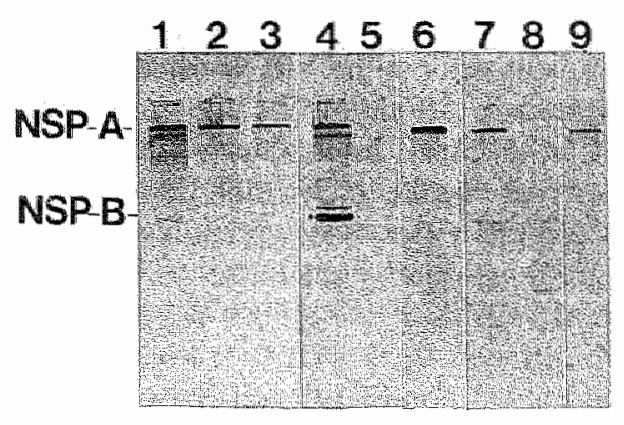

Figure 4. Immunoblots of non-SCLC-NE cell lines NCL-H460 qanes 1,6), NCL-H810 qanes 2,7 ) and NCIHIIS5 (lanes 3,8) as well the adenocarcinoma cell line NCI-H125 (ame 4) and the SCLC cell line NCI-H82 (lane 5,9), Lanes 1-5, immunoblots incubated with antibody POL-1, visualised with the alkaline phosphatase reaction. Lane 6-9, ummunoblots incubated with a mixture of antibodies MON $160-162$ and detected with the chemiluminescence method. Note the presence of NSP-A in the three non-SCLC-NE cell lines. Only in NCI-H82, NSP-B is present.

In the underlying study, we could demonstrate the expression of NSP-A and NSP-C in non-SCLC-NE cell lines. The observed immunofluorescence patterns confirmed the association of NSP-reticulons with the ER as observed previously (compare ref. 17). To further test the sensitivity and specificity of NSP-antibodies in detecting NE differentiation, we compared the immunoreactivity of these antibodies to antibodies directed against conventional NE markers. For this purpose SCLC, non-SCLC and non-SCLC-NE cell lines were used. With respect to the sensitivity of NSP-reticulons it has become obvious from the results presented here that these markers recognize NE differentiation independent of the presence of DCVs. This was also reflected by the positive reaction of NSP-antibodies in cell lines lacking synaptophysin or chromogranin A immunoreactivity. It is known that both markers exhibit a restricted NE reactivity profile resulting in a high specificity but limited sensitivity $[45,46]$. Also when compared to DDC-activity, which is often shown to be expressed in concordance with chromogranin $A$ and DCVs [5]. In this respect $\mathrm{NCl}-\mathrm{H} 460$ represents an extreme example of a cell line with no detectable DCV-constituents and no DDC-activity, but containing high levels of NSP-A, next to NCAM (see also ref. 47), NSE and neurofilament proteins.

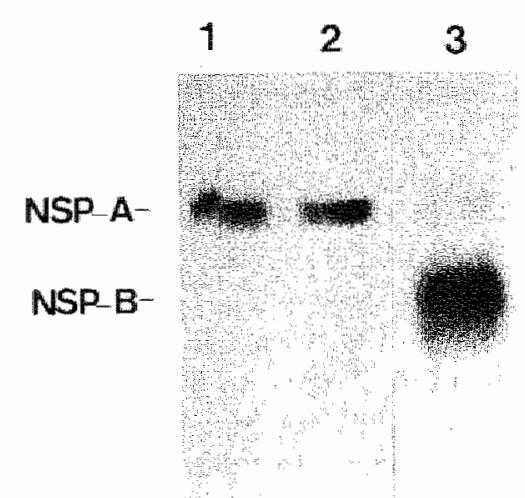

Figure 5. Northern blot andysis of NCH-H460 (lane 1), NCI-H1155 (lane 2) and NCI-H82 (lane 3). Note NSP-A transcripts of $3,4 \mathrm{~kb}$ in both non-SCLC-NE cell lines and in the SCLC cell line NCI-H82. A NSP-B transcript of $2,3 \mathrm{~kb}$ is only present in NCI-H82, whille no NSP-C transcipts $(1,8 \mathrm{~kb})$ could be discerned in these cell lines. 
Neurofilament immunoreactivity is a relative unsensitive indicator for NE differentiation because the number of neurofilament positive cells is considerably lower than the NSP positive cells. Calcitonin expression in this cell line was also not detected, in contrast to the other two non-SCLC-NE cell lines. Since the SCLC cell lines tested were also negative and this NE marker has been described to be variably expressed in lung tumors [4], calcitonin can be regarded as a less sensitive marker for NE differentiation in lung cancer. Also Leu-7, generally believed to be a good indicator for NE differentiation [47], was not as sensitive as the NSP-reticulons, since one of the SCLC, and two of the non-SCLC-NE cell lines were negative. Also, the specificity of this marker is questionable since typical non-SCLC cell lines were found to express Leu-7 [47]. The high specificity of NSP-reticulons for NE differentiation is evident from earlier studies on human lung cancer cell lines (see above). Furthermore, it can be stated that NSP-reticulons show a slightly more restricted reaction pattern than NCAM when tested on a broad panel of human tissues and cells $[13,14,24]$. The three non-SCLC-NE cell lines all showed comparable cell numbers positive for NCAM and NSP-A, although also cells positive for only one of these constituents were detected. NSE-specificity for NE differentiation is generally believed to be questionable since it has been found in non-NE cells and tumors [48]. Also NSE was detected in the non-SCLC cell line LCLC-103H [20], which exhibits no (other) NE features. From this comparison we conclude that NSP-reticulons combine a high sensitivity with a high specificity for detection of $\mathrm{NE}$ differentiation in these lung cancer cell lines and may be a promising marker for the detection of NE differentiation in lung cancer. Since these constituents were not always coexpressed in the same cells with other indicators for NE properties, NSP-reticulons can be regarded as independent NE markers. Recently, a study is performed in which NSP-reticulon expression is compared to the expression of conventional NE markers in solid non-SCLC tumors to determine its value as a marker for NE differentiation (Senden NHM, Timmer EDJ, de Bruine AP, Wagenaar SSC, van de Velde HJK, Roebroek AJM, Van de Ven WJM, Broers JLV, Ramaekers FCS. A comparison of NSP-A and NSP-C with other neuroendocrine markers in neoplasms of the lung, submitted).

\section{Co-occurrence of NE and non-SCLC characteristics in non-SCLC-NE cell lines}

To see whether individual lung cancer cells can combine several differentiation pathways the extent of the co-occurence of the NE features, described above, and markers for non-SCLC differentiation, i.e. cytokeratins, in particular cytokeratin 7, Atype lamins, SP-A and Clara cell protein, was studied. In all three non-SCLC-NE cell lines cytokeratin 8 next to neurofilament expression was observed. This coexpression seems to be characteristic of some NE lung tumors, such as carcinoids, SCLCs and poorly differentiated non-SCLC $[49,50]$. Of these cell lines only NCI-H810 express cytokeratin 7 , a reliable marker for adenocarcinoma type of differentiation and not occurring in SCLC $[28,29]$. The occurrence of cytokeratin 7 next to NE markers clearly indicates the combined phenotype of this cell line. The fact that virtually all NCI-H810 cells contain NSP-reticulons and NCAM, taken together with the observation that $10-20 \%$ of the cells contain cytokeratin 7 , allows the conclusion that this population of cells combines adenocarcinoma features with NE characteristics. The same conclusion seems to apply to NCI-HI155 cells in which SP-A, most frequently found in a subset of adenocarcinomas [51] is found next to NE markers, although in 
this case no cytokeratin 7 was detected. In all three non-SCLC-NE cell lines NE marker expression could be observed in cells strongly expressing A-type lamins, typical for non-SCLC [43], but also in cells with a reduced perinuclear staining or even a negative reaction with antibodies to A-type lamins.

In conclusion, individual non-SCLC-NE cells exhibit an immunophenotype with differentiation characteristics of both SCLC and non-SCLC, supporting the hypothesis that different types of lung carcinomas originate from pluripotent stem cells [52]. NSPreticulon antibodies can be used to detect tumors and tumor cell lines with such dual characteristics and can serve as novel NE-specific markers in lung cancer diagnosis.

\section{Acknowledgements}

The authors thank Dr G Bepler (Durham, NC, USA), Dr D Carney (Dublin, Ireland), Dr H Oie (Rockville, MD, USA) for providing cell lines; Dr G Warren (Heidelberg, Germany), Dr G Krohne (Heidelberg, Germany), Dr Y Raymond (Montreal, Canada) and Dr EB Lane (Dundee, UK) for supplying the antibodies to the lamin proteins. This work was supported by the Dutch Cancer foundation, grant no. IKL 90-09.

\section{REFERENCES}

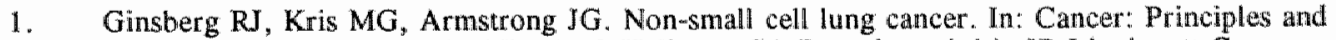
Practice of Oncology. VT DeVita Jr, S Hellman, SA Rosenberg (eds), JBi Lippincott Co, Philadelphia, pp. 673-723, 1994.

2. Ihde DC, Pass HI, Glatstein EJ. Small cell lung cancer. In: Cancer: Principles and Practice of Oncology. VT DeVita Jr, S Hellman, SA Rosenberg (eds), JB Lippincott Co, Philadelphia, Pp. $723-758,1994$.

3. Gazdar AF, Carney DN, Guccion JG, Baylin SB. Small cell carcinoma of the lung: Cellular origin and relationship to other pulmonary tumors. In: Small Cell Lung Cancer. FA Greco, RK Oldham, PA Bunn (eds), Grune \& Stratton, New York, pp. 145-175, 1981.

4. Linnoila RI, Mulshine JL, Steinberg SM, Funa K, Matthews MJ, Cotelingam JD, Gazdar AF. Neuroendocrine differentiation in endocrine and nonendocrine lung carcinomas. Am $\mathrm{J}$ Clin Patholl 90: 641-652, 1988.

5. Gazdar AF, Helman LJ, Israel MA, Russell EK, Linnoila I, Mulshine J, Schuller H, Park JG. Expression of neuroendocrine cell markers $L$-dopa decarboxylase, chromogranin $A$ and dense core granules in human tumors of endocrine and nonendocrine origin. Cancer Res 48: 4078-4082, 1988.

6. Graziano SL, Mazid R, Newman N, Tatum A, Oler A, Mortimer JA, Gullo JI, DiFino SM, Scalzo AJ. The use of neuroendocrine immunoperoxidase markers to predict chemotherapy response in patients with non-small-cell lung cancer. J Clin Oncol 7: 1398-1406, 1989.

7. Berendsen HH, De Leij L, Poppema S, Postmus PE, Boes A, Sluiter HJ. Clinical characterization of non small cell lung cancer tumors showing neuroendocrine differentiation features. J Clin Oncol 7: 1614-1620, 1989.

8. Skow BG, Sorensen JB, Hirsch FR, Larsson $\mathbb{L l}$, Hansen HH. Prognostic impact of histologic demonstration of chromogranin $A$ and neuron-specific enolase in pulmonary adenocarcinoma.. Ann Oncol 2: 355-360, 1991 .

9. Kibbelaar RE, Moolenaar KEC, Michalides RJAM, Van Bodegon PC, Vanderschueren RGJRA, Wagenaar SS, Dingemans KP, Bitter-Suerman D, Dalesio O, Van Zandwijk N, Mooi WJ. Neural cell adhesion molecule expression, neuroendocrine differentiation and prognosis in lung carcinoma. Eur J Cancer 27: 431-435, 1991.

10. Shaw GL, Gazdar AF, Phelps $\mathrm{R}$, Linnoila RI, thde DC, Johnson BE, Oie HK, Pass HI, Steinberg SM, Ghosh BC, Walsh TE, Nesbitt IC, Cotelingham JD. Minna JD, Mulshine IL. Individualized chemotherapy for patients with non-small cell lung cancer determined by prospective identification of neuroendocrine markers and in vitro drug sensitivity testing. Cancer Res 53: 5181-5187, 1993.

11. Graziano SL, Tatum AH, Newman NB, Oler A, Kohman LJ, Veit LJ, Gamble GP, Coleman MJ, Barmada S, O'Lear S. The prognostic significance of neuroendocrine markers and 
carcinombryonic antigen in patients with resected stage I and II mon-small cell lung cancer. Cancer Res 54: 2908-2913, 1994.

12. Linnoila $\mathrm{RI}_{*}$ Piantadosi $S_{3}$ Ruckdeschel JC. Impact of meuroendocrine differentiation in non -small cell lung cancer. Chest suppl 106: 367-371, 1994.

13. Van de Velde HJK, Senden NHM, Roskams TAD, Broers JLV, Ramaekers FCS, Roebroek AVM, Van de Ven WJM. NSP-encoded reticulons are neuroendocrine markers of a novel category in human lung cancer diagnosis. Cancer Res 54: 4769-4776, 1994.

14. Stahel RA, Gilks WR, Lehmann H-P, Schenker T. Third International Workshop on Lung Tumor and Differentiation Antigens: overview of the results of the central data analysis. Int J Cancer suppl 8: 6-26, 1994.

15. Roebroek AJM, van de Velde HJK, Van Bokhoven A, Broers JLV, Ramaekers FCS, Van de Ven WJM. Cloning and expression of alternative transcripts of a novel neuroendocrine-specific gene and identification of its $135-\mathrm{kDa}$ translational product. J Biol Chem 268: 13439-13447, 1993.

16. Van de Velde HJK, Roebroek AJM, Senden NHM, Ramaekers FCS, Van de Ven WJM. NSP-reticulons, neuroendocrine proteins of a novel gene family associated with membranes of theendoplasmic reticulum. I Cell Sci 107: 2403-2416, 1994.

17. Senden NHM, wan de Velde HJK, Broers JLV, Timmer EDJ, Kuijpers HJH, Roebroek AJM, Van de Ven WJM, Ramaekers FCS. Subcellular localization and supramolecular organization of neurcendocrine-specific protein B (NSP-B) in small cell lung cancer. Eur J Cell Biol 65: $341-353,1994$.

18. Brower M, Carney DN, Oie HK, Gazdar AF, Minna JD. Growth of cell lines and clinical specimens of human non-small cell lung cancer in a serum-free defined medium. Cancer Res 46: 798-806 1986 .

19. Lan MS, Russell EK, Lu J, Johnson BE, Notkins AL. IA-1, a new marker for neuroendocrine differentiation in human lung cancer cell lines. Cancer Res 53:4169-4171, 1993.

20. Bepler $G$, Koehler A, Kiefer P, Havemann $\mathbb{K}$, Beisenherz $K$, Jaques $G$, Gropp $C$, Haeder $M$. Characterization of the state of differentiation of six newly established human non-small-cell lung cancer cell lines. Differentiation 37: 158-171, 1988.

21. Carney DN, Gazdar AF, Bepler G, Guccion JG, Marangos PJ, Moody TW, Zweig MH, Minna JD. Establishment and identification of small cell lung cancer cell lines having classic and variant features. Cancer Res 45: 2913-2923, 1985.

22. Gazdar AF, Carney DN, Nau MM, Minna ID. Characterization of variant subclasses of cell lines derived from small cell lung cancer having distinctive biochemical, morphological, and growth properties. Cancer Res 45: 2924-2930, 1985.

23. Broers JLV, Klein Rot M, Oostendorp T, Bepler G, de Leij L, Carney DN, Vooijs GP, Ramaekers FCS. Spontaneous changes in intermediate fulament protein expression patterns in lung cancer cell lines. J Cell Sci 91: $91-108,1988$.

24. Broers JLV, Mijnheere EP, Klein Rot M, Schaart G, SijImans A, Boerman OC, Ramaekers FCS. Novel antigens characteristic of neuroendocrine malignancies. Cancer 67: 619-633, 1991.

25. Abo $\mathrm{T}$, Balch $\mathrm{C}$. A differentiation antigen of human $\mathrm{NK}$ and $\mathrm{K}$ cells identified by a monoclonal antibody (HNK-1). Immumol $127: 1024-1029,1985$.

26. Bunn P, Linnoila I, Minna J, Carney D, Gazdar A. Small cell ling cancer, endocrine cells of the fetal bronchus, and other neuroendocrine cells express the Leu-7 antigenic determinant present on naturall killer cells. Blood 65 : 764-768, 1985.

27. Linnoila RI, Becker KL, Silva OL, Snider RH, Moore CF. Calcitonin as a marker for diethylnitrosamine induced pulmonary endocrine cell hyperplasia in hamsters. Lab Invest 51 : $39-45,1987$.

28. Ramaekers FCS, Huysmans A, Schaart $G$, Moesker $O$, Vooijs P. Tissue distribution of keratin 7 as monitored by a monoclonal antibody. Expl Cell Res 170: 235-249, 1987.

29. Broers JLV, Ramaekers FCS, Klein Rot M, Oostendorp T, Huysmans A, van Muijen GNP, Wagenaar SS, Vooijs GP. Cytokeratins in different types of human lung cancer as monitored by chain-specific monoclonal amibodies. Cancer Res 48: 3221-3229, 1988.

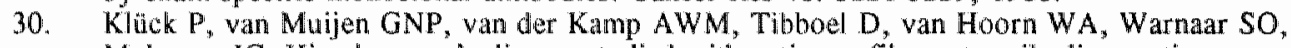
Molenaar JC. Hirschsprung's disease studied with antineurofilament antibodies on tissue sections. Lancet i: $652-654,1984$.

31. Burke B, Tooze $G$, Warren $G$. A monoclonal antibody which recognises each of the nuclear lamin polypeptides in mammalian cells. EMBO J 2: 361-367, 1983.

32. Zatloukal K, Denk H, Spurej $G$, Hutter H. Modulation of protein composition of nuclear lamina reduction of lamins-B1 and lamins-B2 in livers of griseofulvin-treated mice. 
Lab Invest $66: 589-597,1992$.

33. Hozák $P$, Sasseville AM, Raymond $Y$, Cook PR. Lamin proteins form an internal nucleoskeleton as well as a peripheral lamina. J Cell Sci 108: 635-644, 1995.

34. Bridger JM, Kill I, O'Farrell M, Hutchison CJ. Internal lamin structure within Gl nuclei of human dermal fibroblasts. J Cell Sci 104: 297-306, 1993.

35. Van de Velde HJK, Roebroek AJM, van Leeuwen FW, Van de Ven WIM. Molecular analysis of expression in rat brain of NSP-A, a novel neuroendocrine-specific protein of the endoplasmic reticulum. Mol Brain Res 23: 81-92, 1994.

36. Senden NHM, van de Velde HJK, Broers JLV, Timmer EDJ, Roebroek AJM, Van de Ven WJM, Ramaekers FCS. Cluster 10 lung cancer antibodies recognize NSPs, novel neuroendocrine proteins associated with membranes of the endoplasmic reticulium. Int I Cancer suppl 8: 84-88, 1994.

37. Senden NHM, Timmer EDJ, Boers JE, van de Velde HJK, Roebroek AJM, Van de Ven WJM, Broers JLV, Ramaekers FCS. Neuroendocrine-specific protein C (NSP-C): subcellular localization and differential expression in relation to NSP-A. Eur J Cell Biol in press.

38. Deftos LJ, Linnoila RI, Carney DN, Burton DW, Leong SS, O'Connor DT, Murray SS, Gazdar AF. Demonstration of chromogranin $A$ in human neuroendocrine cell lines by immunohistology and immunoassay. Cancer 62: 92-97, 1988.

39. GuJ, Linnoila RI, Seibel NL, Gazdar AF, Minna JD, Brooks BJ, Hollis GF, Kirsch IR. A study of myc-related gene expression in small cell lung cancer by in situ bybridization. Am J Pathol 132: 13-17, 1988.

40. Broers JLV, Jensen SM, Travis WD, Pass H, Whitset JA, Singh G, Katyal SL, Gazdar AF, Minna JD, Linnoila RI. Expression of surfactant associated protein- $A$ and Clara cell 10 killodalton mRNA in neoplastic and non-neoplastic human lung tissue as detected by in situ hybridization. Lab Invest 66: 337-346, 1992.

41. Chirgwin JM, Przybyla AE, MacDonald RJ, Rutter WJ. Isolation of biologically active ribonucleic acid from sources enriched in ribonuclease. Biochem 18:5294-5299, 1979.

42. Feinberg AP, Vogelstein B. A technique for radiolabeling DNA restriction endonuclease fragments to high specific activity. Anal Biochem 132: 6-13, 1983.

43. Broers JLV, Raymond $Y$, Klein Rot $M$, Kuijpers $H$, Wagenaar SSc, Ramaekers FCS. Nuclear A-type lamins are differentially expressed in human lung cancer subtypes. Am J Pathol 143: $211-220,1993$.

44. Gazdar AF, Linnoila RI, Hurita Y, Oie HK, Mulshine JL, Clark JC, Whitsett JA. Peripheral airway cell differentiation in human lung cancer cell lines. Cancer Res 50: $5481-5487,1990$.

45. Jensen SM, Gazdar AF, Cuttitta F, Russell EK, Linnoila RI. A comparison of synaptophysin, chromogranin and I-dopa decarboxylase as markers for neuroendocrine differentiation in lung cancer celll lines. Cancer Res 50:6068-6074, 1990.

46. Tötsch M, Müller LC, Hittmair A, Offner D, Gibbs A, Schmid KW. Immunohistochemical demonstration of chromogranins $A$ and $B$ in neuroendocrine tumors of the lung. Hum Pathol 23: $312-316,1992$.

47. Carbone DP, Koros AMC, Linnoila RI, Jewett P, Gazdar AF. Neural cell adhesion mollecule expression and messenger RNA splicing patterns in lung cancer cell lines ard correlated with neuroendocrine phenotype and growth morphology. Cancer Res 51: 6142-6149, 1991.

48. Pahlman $S$, Esscher $T$, Nilsson $K$. Expression of $\gamma$-subunit of enolase, neuron specific enolase in human non-endocrine tumors and derived cell lines. Lab Invest 54: 554-560, 1986.

49. Broers JLV, Klein Rot M, Oostendorp T, Huysmans A, Wagenaar SSc, Wiersma-van Tiburg AJM, Vooijs G, Ramaekers FCS. Immunocytochemical detection of human lung cancer heterogeneity using antibodies to epithelial, meuronal, and neuroendocrime antigens. Cancer Res 47: $3225-3234,1987$.

50. Van Muijen GNP, Ruiter DJ, wan Leeuwen C, Prins FA, Rietsema $K$, Warnatr $S O$. Cytokeratin and neurofilament in lung carcinomas. Am J Pathol 116:363-369, 1984.

51. Linnoila RI, Jensen SM, Steinberg SM, Mulshine JL, Eggleston JC, Gazdar AF. Peripheral airway cell marker expression in non-s mall cell lung carcinoma. Anat Pathol 97 : $233-243,1992$.

52. Linnoila RI, Aisner SC. Pathology of lung cancer: An exercise in classification. In Lung Cancer, BE Johnson and DH Johnson (eds), Wiley-Liss, New York, pp. 73-95, 1995. 



\title{
CHAPTER 7
}

\section{A COMPARISON OF NSP-A AND NSP-C WITH OTHER NEUROENDOCRINE MARKERS IN NEOPLASMS OF THE LUNG}

Nicole HM Senden, Erika DJ Timmer, Adriaan P de Bruïne, Sjoerd Sc. Wagenaar, Helgi JK van de Velde, Anton JM Roebroek, Wim JM Van de Ven, Jos LV Broers, Frans C.S. Ramaekers

\section{Submitted}

\begin{abstract}
NSP-A and NSP-C have been identified as markers for neuroendocrine (NE) differentiation. In this study NSP-A and NSP-C expression has been investigated in different types of lung cancer and compared to the expression patterns of five conventional NE, i.e. the neural cell adhesion molecule (NCAM), synaptophysin, chromogranin A, leu-7 and neurofilament proteins. NSP-A and NSP-C antibodies were reactive with most carcinoid tumors and small cell lung carcinoma (SCLC) cases, while atypical carcinoid tumors showed a variable expression. In the total group of NE tumors a high concordance of expression was found between NSP-A and NSP-C, while their expression correlated well with NCAM and synaptophysin. Chromogranin A, Leu-7 and neurofilament proteins were shown to be expressed to a limited extent in these NE tumors. In a selected group of non-SCLC, known to exhibit NE features, NSP-A expression was detected in a much higher frequency than NSP-C. In virtually all NSP-A positive cases this expression was associated with one or more of the other NE markers. NSP-A expression showed a stronger correlation to conventional NE markers than NCAM. With respect to its sensitivity in the detection of NE differentiation in non-SCLC, NSP-A appeared to be more sensitive than synaptophysin, chromogranin A, Lell-7 and neurofilament proteins. It is therefore concluded that NSPs are valuable markers in the diagnosis of NE differentiation in non-SCLC, in particular when used in combination with other markers.
\end{abstract}




\section{INTRODUCTION}

NSP-reticulons have been described to be indicators for neural and NE differentiation in normal and malignant cells [1-3]. In the majority of NE tissues, these endoplasmic reticulum associated aggregates consist of two closely related protein constituents, i.e. NSP-A and NSP-C. In lung cancer diagnosis NSP-A appeared to be a reliable marker for the detection of NE differentiation, since most of the SCLC and all carcinoid tumors examined, showed expression of NSP-A. In general, typical non-SCLC showed no expression of this marker [2]. Interestingly, NSP-A expression was also detected in a subset of non-SCLC, in association with expression of other NE markers i.e., NCAM and/or neurofilament proteins [2]. Also in the cell lines derived from these lung cancer subtypes expression of both NSP-A and NSP-C was found in SCLC cultures and not in typical non-SCLC cell lines [2]. The reaction patterns observed in the group of histologically heterogeneous solid non-SCLC are reflected in morphologically non-SCLC cell lines with NE characteristics (non-SCLC-NE). In lung cancer cell lines NSP-A and NSP-C are to a certain extent differentially expressed [3]. Since NSP-A and NSP-C expression was found not to depend on neurosecretory granule density, they are considered to be more sensitive than synaptophysin and chromogranin A (see chapter 6). Cell lines expressing NSP-A and/or NSP-C were in general found to coexpress NCAM and neurofilament proteins, although these markers did often not cooccur at the single cell level. In the present study NSP-A and NSP-C expression was investigated in a series of broncho pulmonary neoplasms, comprising typical carcinoids, atypical carcinoids, SCLC and non-SCLC. Their value as NE markers is assessed by a comparison with other indicators for NE differentiation, i.e. NCAM, synaptophysin, chromogranin A, leu-7 and neurofilament proteins.

\section{MATERIALS AND METHODS}

\section{Tumor specimens}

Surgical specimens of 88 cases of bronchopulmonary tumors were obtained from the Department of Pathology, St. Antonius Hospital, Nieuwegein, The Netherlands. All tumors were rapidly frozen, stored in liquid nitrogen and classified on the basis of routine histological hematoxylin-eosin staining criteria according to the latest WHO classification [4], including atypical carcinoid tumors [5]. No subdivision has been made in poorly, intermediate and well-differentiated non-SCLC.

\section{Antibodies}

The following antibodies were used in this study: mouse monoclonal antibodies (mabs) RNL-2 and RNL-3 (both IgGl subtype) [6] recognizing epitopes present in NSP-A [7] were used as undiluted culture supernatants; mouse mabs MON-160, MON-161 and MON-162 (all of the IgG1 subtype) specific for NSP-A [8,9] were used as a 1:1:1 mix (MON 160-162) in a $1: 5$ dilution of culture supernatant; polyclonal rabbit antiserum POL-1, recognizing epitopes present in NSP-A [8,9], used in a 1:2500 dilution; mouse mab RNL-4 (IgGl subtype) specific for NSP-C [3], used in a 1:4 dilution of culture supernatant; mouse mab RNL-1 (IgG1), recognizing NCAM [6], used as undiluted culture supernatant; polyclonal rabbit antiserum to synaptophysin (DAKO A/S, Glos- 
trup/Denmark), a component of synaptic vesicles and widely distributed in neurons and NE cells [10], used in a 1:50 dilution; mouse mab LK2H10 recognizing chromogranin A (IgG1 subtype; BioGenex, San Ramon, Ca, USA), diluted 1:100. Chromogranin A is associated with dense core vesicles and is present in neural and NE cells [10]; mouse mab HNK-1 (IgM), recognizing Leu-7 (Becton Dickinson, Mountain View, Ca, USA), diluted 1:10; mouse mab KP1 (IgG1 subtype) recognizing CD68 on human macrophages (DAKO A/S), diluted 1:500; mouse Mab MNF (IgGi), reactive with the 68 $\mathrm{kDa}$ and $200 \mathrm{kDa}$ neurofilament subunits [11], diluted $1: 10$; polyclonal rabbit antiserum pNF68 reactive with the $68 \mathrm{kDa}$ neurofilament subunit, diluted 1:400 [12]; polyclonal rabbit antiserum pNF160 reactive with the $160 \mathrm{kDa}$ neurofilament subunit, diluted 1:600 [12].

\section{Immunohistochemical procedure}

Immunohistochemical staining was performed by the indirect immunoperoxidase technique as described before [13]. Briefly, frozen sections (4-6 $\mu \mathrm{m}$ thick) were cut on a cryostat (cryocut 1800 , Leica), air dried and fixed in acetone $\left(-20^{\circ} \mathrm{C}\right)$ for $10 \mathrm{~min}$. The sections were incubated with the primary antibodies for $1 \mathrm{~h}$ in the appropriate dilutions in phosphate buffered saline (PBS; $0.15 \mathrm{M} \mathrm{NaCl}, 10 \mathrm{mM}$ Na-phosphate, $\mathrm{pH}$ 7.2). After repeated washing in PBS, sections were incubated for $1 \mathrm{~h}$ with peroxidase conjugated rabbit anti-mouse immunoglobulins ( $\mathrm{Ig} ; \mathrm{DAKO} \mathrm{A} / \mathrm{S}$ ) or with peroxidase conjugated swine anti-rabbit Ig (DAKO A/S), both diluted 1:100 in PBS containing 5\% human $\mathrm{AB}$ serum. After washing in PBS, peroxidase activity was detected with 3amino-9-ethylcarbazole (AEC; Sigma, St. Louis, MO, USA). $40 \mathrm{mg}$ of AEC was dissolved in $10 \mathrm{ml} \mathrm{N}$-N-dimethylformamide (Merck, Darmstadt, FRG) and added to $190 \mathrm{ml}$ of $0.05 \mathrm{M}$ sodium acetate buffer, $\mathrm{pH} 4.85$. Hydrogen peroxide was added to a final concentration of $0.01 \%$. Slides were incubated for $10 \mathrm{~min}$, then sections were washed in aqua dest, counterstained with hematoxylin and mounted with Kaisers glycerol gelatin (Merck). Slides were viewed with a Zeiss Axiophot microscope (Zeiss Oberkochen/Germany) and photographed using a 25 ASA Agfa Pan film (Agfa, Leverkusen, Germany). In the negative controls the primary antiserum was replaced by PBS.

\section{Evaluation of immunohistochemical staining results}

The different NSP-A antibodies showed virtually identical staining patterns in all cases examined. However, the Mabs RNL-2 and RNL-3 showed in general a less intense immunoreactivity as compared to the mab mixture MON $160-162$ and the polyclonal antiserum POL-1. Since NSP-A antibodies show occasionally immunoreactivity with macrophages $[3,14]$, those tumors in which NSP-A antibody reactivity was not confined to the tumor cells and which were also positive for CD68, were scored negative for NSP-A. In general, when virtually all tumor cells expressed a certain marker, its expression is defined as being diffuse. Focal positivity is defined as reactivity $(>10 \%)$ in a part of the tumor, or when staining is found in scattered cells. 


\section{Chapter ?}

\section{RESULTS}

The results of the immunohistochemical reactions are summarized in Tables 1-4 and illustrated in Figs. 1-4.

Table 1.

Immunohistochemical staining patterns of NSP-A and NSP-C in relation to other neuroendocrine markers in various histologic lung cancer subtypes

\begin{tabular}{|l|ccccc|}
\hline NEa markers & carcinoid & $\begin{array}{c}\text { atypical } \\
\text { carcinoid }\end{array}$ & SCLC & $\begin{array}{c}\text { squamous cell } \\
\text { carcinoma }\end{array}$ & adenocarcinoma \\
\hline NSP-A & $5 / 5$ & $2 / 5$ & $6 / 8$ & $16 / 52$ & $2 / 18$ \\
NSP-C & $4 / 5$ & $1 / 5$ & $6 / 8$ & $2 / 52$ & $1 / 18$ \\
NCAM & $5 / 5$ & $3 / 5$ & $8 / 8$ & $19 / 52$ & $1 / 18$ \\
Syn & $2 / 2$ & $3 / 5$ & $8 / 8$ & $7 / 49$ & $2 / 18$ \\
CgA & $2 / 2$ & $1 / 4$ & $1 / 7$ & $2 / 51$ & $0 / 18$ \\
Leu-7 & $1 / 1$ & $1 / 3$ & $3 / 5$ & $7 / 48$ & $3 / 18$ \\
NF & $1 / 3$ & $0 / 4$ & $1 / 6$ & $5 / 51$ & $0 / 18$ \\
\hline
\end{tabular}

a: abbreviations used are: NE, neuroendocrine; Syn, synaptophysin; CgA, chromogranin A; NF, neurofilaments.

\section{Carcinoids}

The immunophenotype of the individual carcinoid cases is shown in Table 2. NSP-A expression was observed in all five carcinoid cases tested. A strong cytoplasmic immunoreactivity was observed in 4 cases (Fig. IA), in virtually all tumor cells, while in one case a focal expression was seen. For NSP-C a focal immunoreactivity pattern could be detected in 4 of the 5 carcinoid tumors (Fig. IB), while one case was negative. In all these cases NCAM expression was present as a membranous staining in most cells (Fig. 1C). The two cases tested for synaptophysin were diffusely positive for this marker (Fig. ID), one of which also showed a diffuse positive reaction for chromogranin A and the other case exhibited a focal chromogranin A expression. Neurofilament proteins were observed in 1 of the 3 carcinoid tumors tested.

\section{Atypical carcinoids}

The immunophenotypes of the atypical carcinoid tumors are shown in Table 2. A strong diffuse NSP-A expression was observed in 2 out of 5 cases (Fig. 1E), while NSP-C was focally present in one case (Fig. 1F), which also expressed NSP-A. In these NSP positive tumors also other NE markers were present i.e., NCAM (Fig. 1G) and synaptophysin were found in both NSP-positive cases, while chromogranin A (Fig. 1H) and Leu-7 were found in one of these two cases. In addition, one atypical carcinoid tumor, negative for NSP, exhibited NCAM and synaptophysin. Neurofilament expression could not be detected in these tumors. 
Table 2.

Immunophenotypes of the neuroendocrine tumors tested in this study

\begin{tabular}{|c|c|c|c|c|c|c|c|}
\hline $\mathrm{NE}^{a}$ tumors & NSP-A & NSP-C & NCAM & Syn & $\mathrm{CgA}$ & Leu-7 & $\mathrm{NF}$ \\
\hline \multicolumn{8}{|l|}{ Carcinoids } \\
\hline 1 & $F^{b}+$ & - & $\mathrm{D}+$ & $\mathrm{nd}$ & nd & nd & - \\
\hline 2 & $\mathrm{D}+$ & $F+$ & $D+$ & nd & nd & nd & nd \\
\hline 3 & $\mathrm{D}+$ & $F+$ & $D+$ & nd & nd & nd & nd \\
\hline 4 & $\mathrm{D}+$ & $\mathbb{F}+$ & $D+$ & $\mathrm{D}+$ & $D+$ & $D+$ & - \\
\hline 5 & $D+$ & $F+$ & $D+$ & $D+$ & $\mathrm{F}+$ & nd & $\mathrm{F}+$ \\
\hline \multicolumn{8}{|c|}{ Atypical Carcinoids } \\
\hline 1 & $D+$ & $\mathrm{F}+$ & $D+$ & $D+$ & $\mathrm{F}+$ & $\mathrm{F}+$ & - \\
\hline 2 & $D+$ & - & $D+$ & $D+$ & - & - & - \\
\hline 3 & - & - & $D+$ & $D+$ & - & - & - \\
\hline 4 & - & - & - & - & - & nd & nd \\
\hline 5 & - & - & - & - & nd & nd & - \\
\hline \multicolumn{8}{|l|}{ SCLC } \\
\hline 1 & $F+$ & $\mathrm{C}+$ & $\mathrm{D}+$ & $D+$ & - & $\mathrm{F}+$ & - \\
\hline 2 & $F+$ & $\mathrm{C}+$ & $D+$ & $\mathrm{D}+$ & - & $\mathrm{C}+$ & - \\
\hline 3 & $\mathrm{D}+$ & $\mathrm{D}+$ & $\mathrm{D}+$ & $\mathrm{D}+$ & - & $\mathrm{F}+$ & - \\
\hline 4 & $\mathrm{D}+$ & $C+$ & $D+$ & $\mathrm{D}+$ & - & - & - \\
\hline 5 & $\mathrm{D}+$ & $\mathrm{D}+$ & $\mathrm{D}+$ & $\mathrm{D}+$ & $\mathbb{F}+$ & - & $\mathrm{F}+$ \\
\hline 6 & $\mathrm{~F}+$ & - & $D+$ & $D+$ & - & nd & - \\
\hline 7 & $=$ & $\mathrm{F}+$ & $\mathrm{D}+$ & $\mathrm{D}+$ & - & nd & nd \\
\hline 8 & - & - & $\mathrm{D}+$ & $\mathrm{D}+$ & nd & nd & nd \\
\hline
\end{tabular}

a.: abbreviations used are: NE, neuroendocrine; Syn, synaptophysin; $C g A$, chromogranin $A$; $N F$, neurofilament proteins; nd, not done.

b: Staining patterns are indicated as: $F+$, focal positivity in groups of cells or scattered cells; $D+$, virtually all cells positive; $C+$, combined pattern i.e. large part of the tumor diffusely positive, while other part only focally positive; -, no staining. 

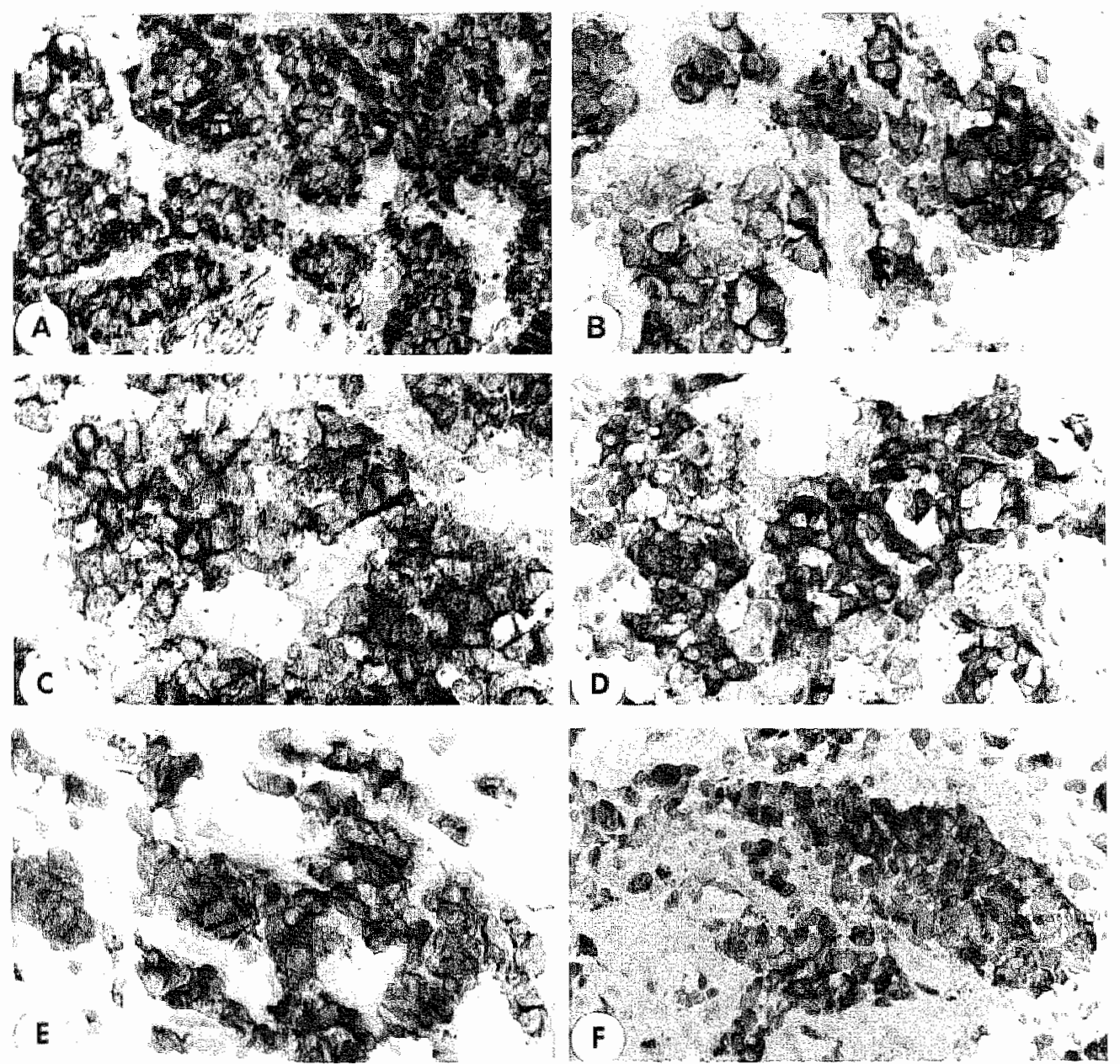

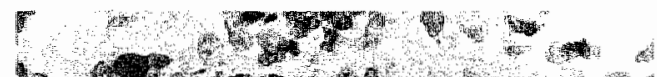

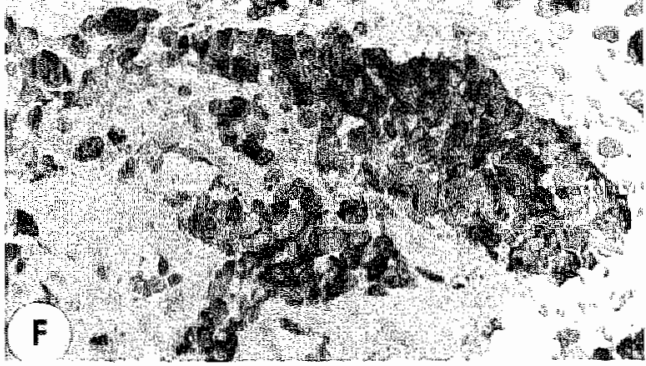
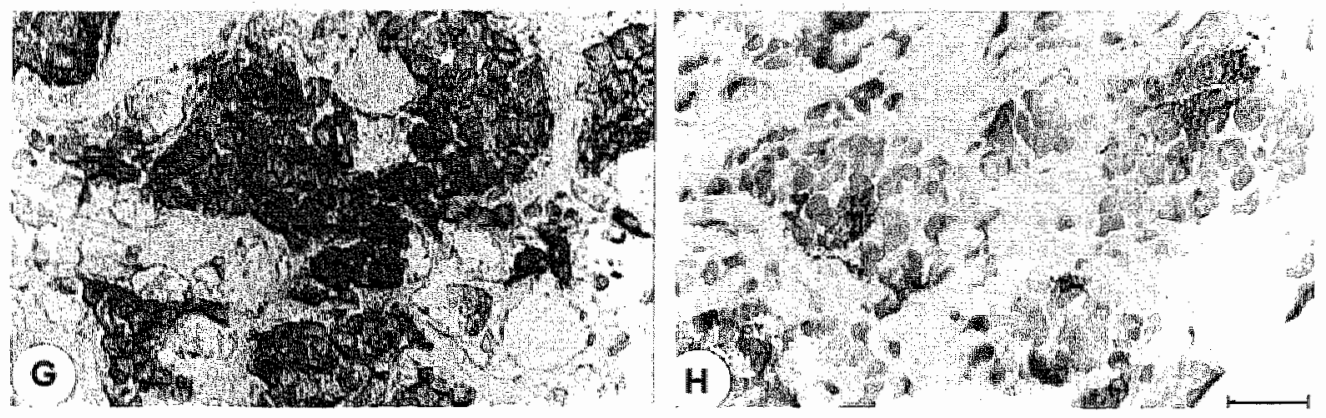

Figure 1. Immunoreactivity patterns of a carcinoid of the lung (A-D) and a atypical carcinoid $(E-F)$, characterized by MON $160-162$ for NSP-A (A,E), RNL-4 for NSP-C (B,F), RNL-1 for NCAM $(C, G)$, polyclonal anti-synaptophysin (D) and LK2H10 for chromogranin A (H). Bar: $25 \mu \mathrm{m}$ in (A-E); $20 \mu \mathrm{m}$ in $(\mathrm{F}-\mathrm{G})$. 


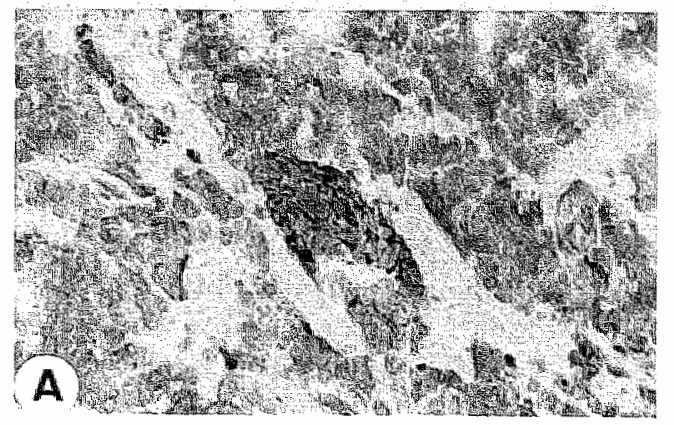

r.t.

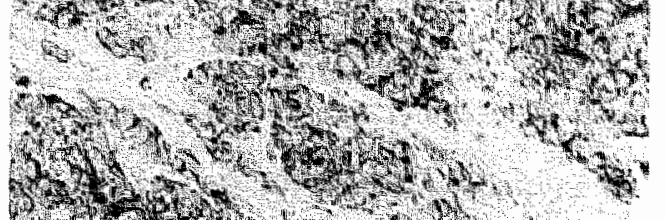
H. W

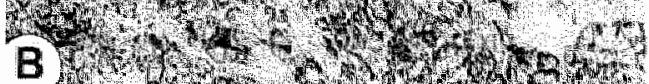

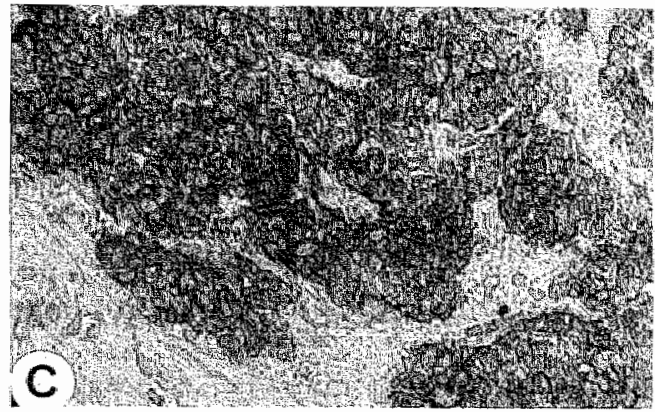

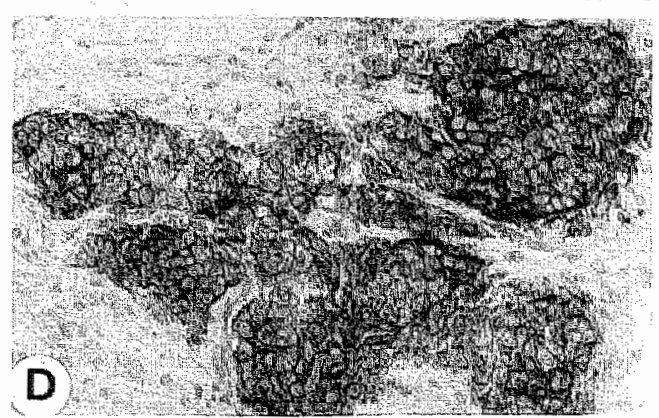

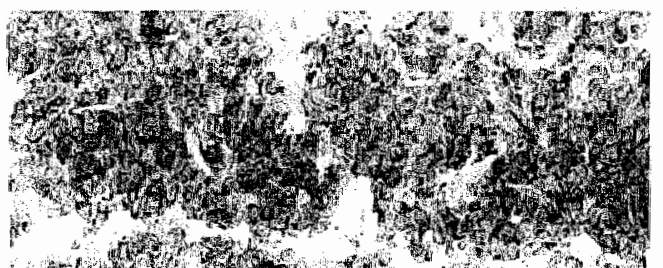

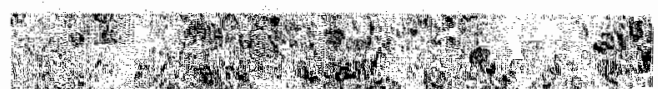

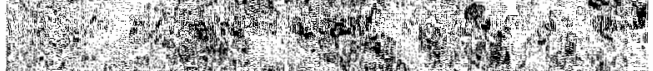
W.1.

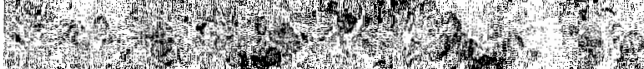
H.

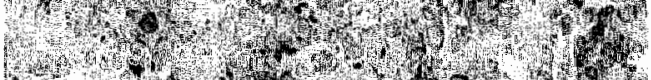

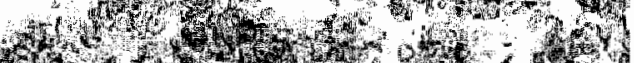

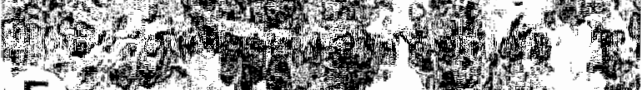
E

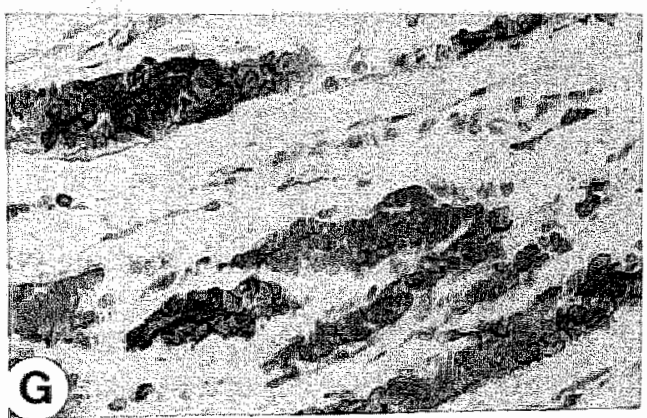
Prat

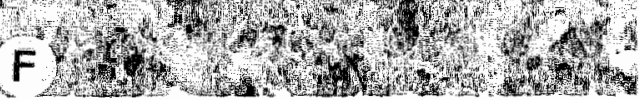

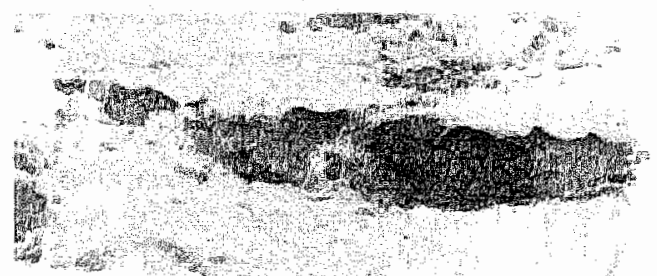

Figure 2. Immunoreactivity patterns of SCLC, characterized by MON 160-162 for NSP-A (A, E, G), RNL-4 for NSP-C (B,F), RNL-1 for NCAM (C), polyclonal anti-synaptophysin (D) and HNK-1 for Leu-7 (H). Bar: $45 \mathrm{~km}$. 


\section{SCLC}

Table 2 summarizes the immunophenotypes of the individual SCLC cases. The NSP-A antibodies reacted positively in 6 of 8 cases of SCLC examined. In three cases a focall staining reaction was seen (Figs. $2 \mathrm{~A}$ and $2 \mathrm{G}$ ), while in the other three positive cases a diffuse immunoreactivity was present (Fig. 2E). Likewise, NSP-C could be detected in 6 SCLC cases examined. In two cases diffuse expression of NSP-C in all tumor cells was observed (Fig. 2B) and in three cases a combined pattern was seen, in that a part of the tumor was diffusely positive while the other part showed only focal expression of NSP-C. One SCLC case was only focally positive. Of eight SCLC, five showed coexpression of both NSP-A and NSP-C (compare Figs. 2A and 2B; Figs. 2E and 2F), although the intensity of expression per individual tumor and per marker varied. In two cases either NSP-A or NSP-C were present. In all NSP-posititive SCLC NCAM (Fig. 2C) and synaptophysin (Fig. 2D) could be detected in virtually all tumor cells, while Leu-7 (Fig. 2H) was present in three and chromogranin $A$ and neurofilament protein immunoreactivity was found in one case.

\section{Squamous cell carcinoma}

The total group of 52 cases of squamous cell carcinoma tested, consisted of a group of 21 cases preselected from a larger series (approximately 200 cases) on basis of their positivity for NCAM and/or neurofilaments (15). The remaining 31 cases of squamous cell carcinoma were chosen on basis of their absence of NCAM and neurofilaments (15). When examined for the complete spectrum, 28 of the 52 cases showed NE markers (see Table 3) ranging from one marker (10/28), two markers $(9 / 28)$, three markers $(6 / 28)$ to four NE markers $(3 / 28)$ present. In these squamous cell carcinomas NSP-A expression was observed in 16 out of 52 cases (see Table 1), with only focal immunoreactivity in all these positive cases (Figs. $3 \mathrm{~A}$ and $3 \mathrm{E}$ ). NSP-C could be detected in two of the 52 cases (Fig. 3B), one of which was also positive for NSP-A (compare Figs. $3 \mathrm{~A}$ and $3 \mathrm{~B}$ ). With the exception of 3 tumors NSP-positive cases showed the presence of other NE markers. Most of these show NCAM positivity (Figs. $3 \mathrm{C}, \mathrm{H}$ ) next to NSP-A expression (10 of $16 \mathrm{NSP}-\mathrm{A}$ positive cases). In contrast, NCAM was found to be the only NE marker detected in 7 cases. Synaptophysin (Fig. 3F) and Leu-7 (Fig. 3G) expression was observed in 7 cases, while chromogranin A was detected in two squamous cell carcinomas. Five cases, of squamous cell carcinoma were shown to express at least one of the neurofilament subunits (Fig. 3D), which always co-occurred with at least one other NE marker.

\section{Adenocarcinoma}

Six of the 18 cases of adenocarcinoma tested exhibited NE features (see Table 4), ranging from one marker (4/6), two markers (1/6) to three markers (1/6) present. NSP-A expression was observed in two of these cases (Fig. 4A), while a strong NSP$\mathrm{C}$ expression was seen in one case (Fig 4B). In one adenocarcinoma case expression of NCAM was seen, two cases showed the presence of synaptophysin, while three adenocarcinomas contained Leu-7. No neurofilament expression has been found. 
Table 3.

Immunophenotypes of squanous cell carcinomas

\begin{tabular}{|c|c|c|c|c|c|c|c|}
\hline SQC cases & NSP-A & $\mathrm{NSP}-\mathrm{C}$ & NCAM & Syn & $\mathrm{Cg} A$ & Lew-7 & NF \\
\hline 1 & $-b$ & $\mathrm{C}+$ & - & $\mathrm{D}+$ & $\mathrm{C}+$ & $\mathrm{C}+$ & - \\
\hline 2 & $\mathrm{~F}+$ & $\mathrm{F}+$ & $\mathrm{F}+$ & - & - & - & $\mathrm{F}+$ \\
\hline 3 & $\mathrm{C}+$ & - & $\mathrm{F}+$ & $D+$ & - & $\mathrm{F}+$ & - \\
\hline 4 & $\mathrm{~F}+$ & - & $C+$ & - & - & $F+$ & - \\
\hline 5 & $F+$ & - & $\mathrm{F}+$ & nd & - & $\mathrm{F}+$ & - \\
\hline 6 & $\mathrm{~F}+$ & * & $\mathrm{F}+$ & - & - & $F+$ & - \\
\hline 7 & $\mathrm{~F}+$ & - & - & $D+$ & - & - & $C+$ \\
\hline 8 & $\mathrm{~F}+$ & - & - & - & - & 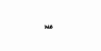 & $\mathrm{C}+$ \\
\hline 9 & $\mathrm{~F}+$ & - & - & $\mathrm{F}+$ & - & $\mathrm{F}+$ & - \\
\hline 10 & $\mathrm{~F}+$ & - & $\mathrm{F}+$ & - & * & - & . \\
\hline 11 & $\mathrm{~F}+$ & - & $D+$ & - & - & - & - \\
\hline 12 & $\mathrm{~F}+$ & - & $\mathrm{F}+$ & - & - & - & nd \\
\hline 13 & $F+$ & - & $\mathrm{F}+$ & nd & . & nd & - \\
\hline 14 & $\mathrm{~F}+$ & - & $\mathrm{F}+$ & - & - & - & - \\
\hline 1.5 & $F+$ & - & - & - & - & - & - \\
\hline 16 & $\mathrm{~F}+$ & - & - & - & - & - & . \\
\hline 17 & $\mathbb{F}+$ & - & - & - & - & nd & - \\
\hline 18 & - & - & $C+$ & $\mathrm{F}+$ & - & - & - \\
\hline 19 & - & - & $\mathrm{F}+$ & $D+$ & - & - & $\mathrm{F}+$ \\
\hline 20 & - & - & $\mathrm{F}+$ & - & - & - & - \\
\hline 21 & - & - & $\mathbb{F}+$ & - & - & . &. \\
\hline 22 & - & - & $\mathbb{E}+$ & - & - & . & - \\
\hline 23 & - & - & $\mathrm{F}+$ & - & - & - & - \\
\hline 24 & - & - & $D+$ & - & - & - & - \\
\hline 25 & - & - & $F+$ & - & - & - & - \\
\hline 26 & - & - & $C+$ & - & . & - & - \\
\hline 27 & - & - & - & - & $\mathbb{E}+$ & $\mathrm{F}+$ & - \\
\hline 28 & - & . & - & $D+$ & - & - & $\mathrm{F}+$ \\
\hline $29-52$ & - & - & - & - & - & - & - \\
\hline
\end{tabular}

a: abbreviations used are: SQC, squamous cell carcinoma; Syn, synaptophysin; CgA, chromogranin A; $\mathrm{NF}_{x}$ neurofilament proteins; nd, not done.

t: F+, focal positivity in groups of cells or scattered cells; D+, virtually all cells difffusely positive; $\mathrm{C}+$, combined pattern i.e. large part of the tumor diffusely positive, while other part only focally positive; -, no staining. 

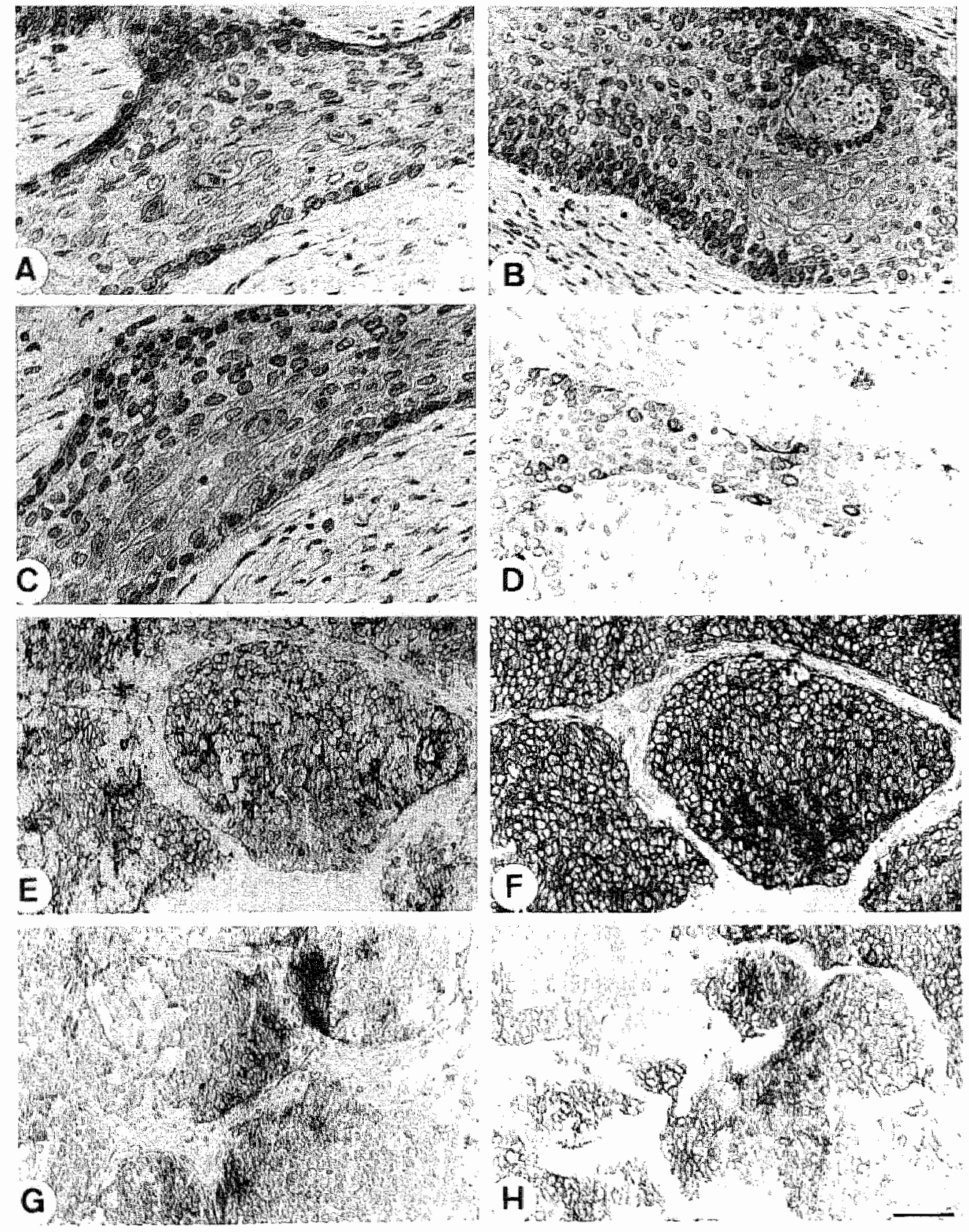

Figure 3. Immunoreactivity patterns of two squamous cell carcinoma cases. The tumor presented in (A-D) is characterized by RNL-2 for NSP-A (A), RNL-4 for NSP-C (B), RNL-1 for NCAM (C) and MNF for neurofilament proteins (D). The tumor in (E-H) is characterized by MON 160-162 for NSPA (A), polyclonal anti-synaptophysin (F), HNK-1 for Leu-7 (G) and RNL-1 for NCAM (H).

Bar: $40 \mu \mathrm{m}$ in $(\mathrm{A}, \mathrm{B}, \mathrm{C}) ; 50 \mu \mathrm{m}$ in (D) and $55 \mu \mathrm{m}$ in $(\mathrm{E}-\mathrm{H})$. 
Table 4.

Immunophenotypes of adenocarcinomas

\begin{tabular}{|c|c|c|c|c|c|c|c|}
\hline $\mathrm{AC}^{a}$ cases & NSP-A & NSP-C & NCAM & Syn & $\mathrm{CgA}$ & Leu 7 & $\mathrm{NF}$ \\
\hline 1 & $\mathrm{~F}+b$ & $D+$ & - & - & - & 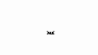 & - \\
\hline 2 & $F+$ & - & $\mathrm{F}+$ & - & - & $F+$ & - \\
\hline 3 & - & $=$ & - & $\mathbb{F}+$ & - & - & - \\
\hline 4 & - & - & - & $D+$ & - & - & - \\
\hline 5 & - & - & - & - & .. & $\mathrm{F}+$ & $\ldots$ \\
\hline 6 & - & - & - & - & - & $\mathrm{F}+$ & - \\
\hline $7-18$ & - & - & - & - & - & - & - \\
\hline
\end{tabular}

$a_{\text {". }}$ abbreviations used are: $\mathrm{AC}$, adenocarcinoma; Syn, synaptophysin; $\mathrm{CgA}$, chromogranin $\mathrm{A}$; $\mathrm{NF}$, neurofillament proteins; nd, not done.

$b_{*} \mathrm{~F}+$, focal positivity in groups of cells or scattered cells; $\mathrm{D}+$, virtually all cells diffusely positive; -, no staining.
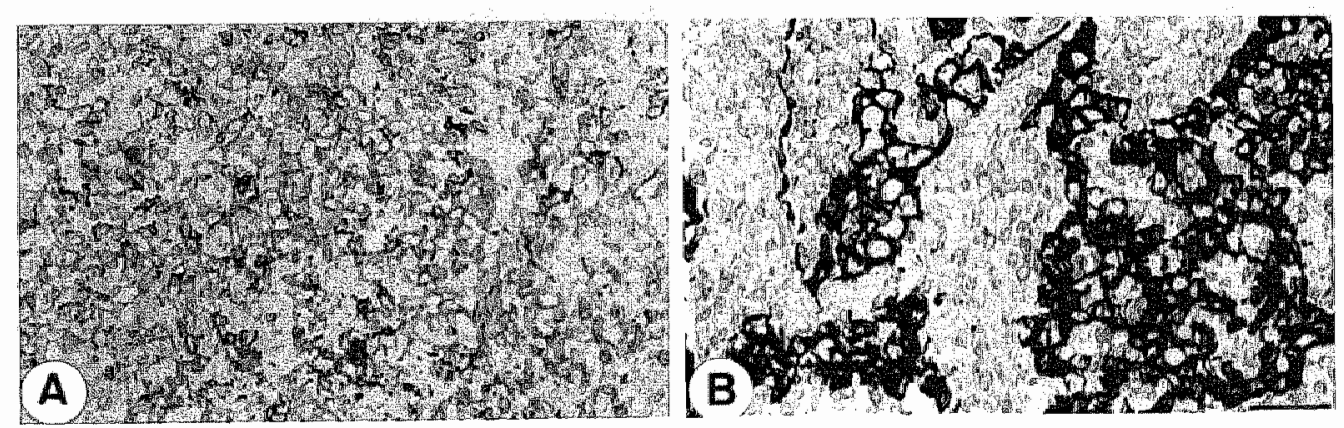

Figure 4. Immunoreactivity patterns of a adenocarcinoma case characterized by MON 160-162 for NSP-A (A) and RNL-4 for NSP-C (B). Bar: $40 \mu \mathrm{m}$. 


\section{DISCUSSION}

NSP-expression has been examined in the main subtypes of pullmonary neoplasms and was studied in relation to the expression patterns of other, conventional NE markers. Comparison of the staining patterns of NSP-A with NSP-C on the one hand, and of these NSPS with the conventional NE markers on the other hand, has revealed that:

1) A high concordance between expression of NSP-A and NSP-C was found in NE tumors of the lung, while in non-SCLC NSP-A occurred in a much higher frequency than NSP-C.

2) In NE tumors NSP-A and NSP-C expression correlates well with NCAM and synaptophysin, while their independence of the presence of neurosecretory vesicles is reflected by the presence of both NSPs in SCLC, which are mainly negative for chromogranin A. Strikingly, NSPs were often absent in atypical carcinoids.

3) In those non-SCLC, showing indications of a NE immunophenotype, NSP-A expression was virtually always associated with one or more (up to three) other NE markers. NCAM exhibited a much weaker correlation to other NE markers. Therefore, in squamous cell carcinoma NSP-A is considered to be a more reliable NE marker than NCAM and more sensitive than synaptophysin, chromogranin A, Leu-7 or neurofilaments.

\section{Concordance between expression of NSP-A and NSP-C}

Of the typical NE tumors expressing NSP-A ( 13 cases) 11 cases also expressed NSP$C$, while conversely, 10 of the 11 NSP-C positive cases contained also NSP-A. This indicates a high concordance in expression between NSP-A and NSP-C in the NE tumors. In the non-SCLC, however, concordance between expression of these two components was low, since NSP-C is only coexpressed in a few cases of NSP-A positive tumors (3 out of 18 ). We have previously shown $[2,3$, see also chapter 6 ) that NSP-A and NSP-C are to some extent differentially expressed in cell lines derived from NE lung cancers, and wondered whether also in their solid lung tumor counter parts such a disparity would occur. However, as mentioned above, in the typical NE tumors only few cases with differential expression patterns of NSP-A and NSP-C were observed.

\section{Comparison of NSP-A and NSP-C to NCAM}

The extent of expression of NSP-A and/or NSP-C approximates that of NCAM, which is positive in virtually all typical NE cases. In this respect coexpression of NSP-A and NCAM in SCLC and non-SCLC-NE cell lines was shown before (see Chapter 6). However, in these cultures no complete overlap was seen between these markers at the single cell level, NSPs being in general less abundant than NCAM. A similar observation is made in the solid NE tumors, in which often only a fraction of the NCAM positive cells appeared to contain NSPs. With respect to their application in tumor dingnosis, Broers et al. [6] have previously described on the high sensitivity of NCAM as marker for NE differentiation. On the other hand the specificity of NCAM for NE cells has been disputed. Kibbelaar et al. [16] detected NCAM in cells lacking dense core granules and concluded that NCAM positivity is not absolutely specific for NE differentiation. Furthermore, NCAM expression has been found in a range of nonNE cells $[6,14,17]$. We have found a considerable number of cases of non-SCLC with 
NCAM positivity, not supported by the presence of another NE marker, while virtually all NSP-A positive cases were also found to contain one or more of the other NE markers. Therefore, we conclude that NSP-A expression shows a stronger correlation to conventional NE markers than NCAM.

\section{Comparison of NSP-A and NSP-C with markers of neurosecretory granules}

Previous studies have shown that synaptophysin is a useful marker in NE pulmonary tumors of all grades $[18,19]$, although studies have reported a variable synaptophysin expression in SCLC $[10,18,20]$. However, in cell cultures of SCLC, synaptophysin expression appeared to be very useful even for the detection of $\mathrm{NE}$ differentiation in the variant-SCLC type [21], in general lacking neurosecretory vesicles [22]. On basis of results in lung cancer derived cell lines, NSPs were considered more sensitive markers for NE differentiation than synaptophysin (see Chapter 6). However, in the underlying study synaptophysin is found to be a slightly more sensitive marker than NSPs in typical NE tumors. In general, it can be stated that NSP-positive NE tumors are always positive for synaptophysin, while the opposite is true in a slightly less number of cases. In particular, atypical carcinoids were often found to be negative for NSPs, while synaptophysin was detected more often. The absence of NSPs as opposed to other NE markers in atypical carcinoid may be of diagnostic relevance, as these tumors require extensive surgical therapy, whereas SCLC on the one hand is treated with combined chemo- and radiotherapy, and the typical carcinoid tumor on the other hand are adequately treated with local excision (23). Strikingly, in non-SCLC the frequency of NSP-A expression is much higher than synaptophysin (18 vs. 9 cases). In these malignancies only four cases showed coexpression of these two markers, while synaptophysin occurred independent of NSPs in 5 of the 9 positive cases. Also nonSCLC-NE cell lines showed a broader expression of NSPs as compared to synaptophysin. It is known that SCLCs express chromogranin A in only a low percentage of the cases [20,24-26], merely due to their low granule content in these poorly differentiated neoplasms. Indeed, we found a decreasing fraction of cases positive for chromogranin A, with the predicted decrease in granule content when going from carcinoid to SCLC (see Table 2), while non-SCLC showed sporadic expression. It may be obvious that chromogranin $\mathrm{A}$ has to be considered an relatively insensitive, but specific marker for NE differentiation in lung cancer.

\section{Reliable detection of neuroendocrine differentiation in non-SCLC}

In general, our results with the NE markers in non-SCLC tumors are in agreement with previously published data. However, because of the selection of non-SCLC on basis of NE markers, the frequency of NE differentiation in the non-SCLC population used in this study does not reflect the actual frequency of NE characteristics in this group as observed in other, randomized studies. Various groups have reported on the presence of NE markers in non-SCLC, ranging from 10-30\% of the cases and mostly accurring in adenocarcinoma $[16,19,22,24,26-31]$. In our study NE marker expression is more often found in squamous cell carcinomas than in adenocarcinomas.

Several studies have questioned whether immunohistochemical detection of NE features in non-SCLC reflects a histologically mixed phenotype. It is beyond doubt that caution has to be taken in the interpretation of the usefulness of certain NE markers, since several of these are not restricted to neuroendocrine tissues. For instance, neuron 


\section{Chapter 7}

specific enolase is not a reliable NE marker because it has been found in other than neural and NE tissues $[32,33]$. On the other hand, although highly specific, markers for neurosecretory granules, often have a limited sensitivity $(18,24,25)$, caused by low neurosecretory granules content in poorly differentiated tumors. Such granules have been detected by electron microscopy in a small number in non-NE tumors [34]. Alll these studies show that the individual criteria for identification of NE differentiation are not absolute and should therefore be combined whenever possible. The underlying study shows that NSPs may play an important role in the detection of NE differentiation in otherwise non-NE malignancies.

Research efforts are now concentrating on the importance of NE differentiation in nonSCLC, since NE differentiation is often presumed to be correlated with aggressive growth and response to chemotherapy. The studies dealing with this question have, however, reached conflicting conclusions. Several studies have indeed shown that nonSCLC expressing NE markers have a poorer prognosis than typical non-SCLC $[16,28]$, while others showed no correlation between NE differentiation and survival $[29,31]$. Moreover, some studies have shown that non-SCLC with NE differentiation have a better response to chemotherapy [30,35-37), although not always resulting in survival advantage $[30,35,37]$. An extended study of NSP-A and NSP-C expression in correlation with clinical behaviour will have to reveal whether these independent NE markers are better prognosticators than the conventional NE markers.

\section{Acknowledgements}

The authors thank Y. Nakazato (Gumna University, Gumna, Japan) for providing the polyclonal antisera to the neurofilament proteins.

\section{REFERENCES}

1. Senden NHM, van de Velde HJK, Broers JLV, Timmer EDJ, Roebroek AJM, Van de Ven WJM, Ramaekers FCS. Cluster- 10 ling cancer antibodies recognize NSPs, novel neuroendocrine proteins associated with membranes of the endoplasmic reticulum. Int $\mathrm{J}$ Cancer suppl 8: 84-88, 1994.

2. Van de Velde HJK, Senden NHM, Roskams TAD, Broers JLV, Ramaekers FCS, Roebroek AJM, Van de Ven WJM. NSP-encoded reticulons are neuroendocrine markers of a novel category in human lung cancer diagnosis. Cancer Res 54: 4769-4776, 1994.

3. Senden NHM, Timmer EDJ, Boers JE, van de Velde HJK, Roebroek AlM Van de Ven WJM, Broers JLV, Ramatekers FCS. Neuroendocrine-specific protein C (NSP-C): subcellular localization and differential expression in relation to NSP.A. Eur J Cell Biol, in press.

4. The World Health Organization histological typing of lung tumours. Am J Clin Pathol 77: $123-136,1982$.

5. Arrigoni MG, Wooner LB, Bernatz PE. Atypical carcinoid humours of the lung. I Thoracic Cardiovase Surg $64: 413-421,1972$.

6. Broers JLV, Mijnheere EP, Klein Rot M, Schaart G, Sijlmans A, Boerman OC, Ramaekers FCS. Novel antigens characteristic of neuroendocrine malignancies. Cancer 67: 619-633, 1991.

7. Senden NHM, van de Velde HJK, Broers JLV, Timmer EDJ, Kuijpers HJH, Roebroek AJM, Van de Ven WJM, Ramakers FCS. Subcellular localization and supramolecular organization of neuroendocrine-specific protein B (NSP-B) in small cell lung cancer. Eur J Call Biol 65: 341-353, 1994.

8. Van de Velde HJK, Roebroek AJM, Van Leewwen FW, Van de Ven WJM. Molecular analysis of expression in rat brain of NSP-A, a novel neuroendocrine-specific protein of the endoplasmic reticulum. Mol Brain Res 23: 81-92, 1994.

9. Van de Velde HJK, Roebroek AJM, Senden NHM, Ramaekers FCS, Van de Ven WJM. NSP-reticulons, meuroendocrine proteins of a novel gene family associated with membranes of the 
endoplasmic reticulum. I Cell Sci., 107: 2403-2416, 1994

10. Wiedenmann B, Huttmer WB. Synaptophysin and chromogranins/secretogranins-widespread constituents of distinct types of neuroendocrine vesicles and new tools in tumor diagnosis. Virchows Archiv B Cell Pathol 58: 95-121, 1989.

11. Klück P, van Muyen GNP, van der Kamp AWM, Tibboel D, van Hoorn WA, Warnaar SO, Molenaar JC. Hirschsprung"s disease studied with monoclonal antineurofiament antibodies on tissue sections. Lancet, 1: 652-654, 1984.

12. Nakazato $Y$, Sasaki $A$, Hirato J, Ishida $Y$. Immunohistochemical localization of neurofillament protein in neuronal degenerations. Acta Neuropathol 64: 30-36, 1984.

13. Broers JLV, Ramaekers FCS, KIein Rot M, Oostendorp T, Huysmans A, Muijen GNP, wagenaar SS, Vooijs GP. Cytokeratins in different types of lung cancer as monitored by chain-specific monoclonal antibodies. Cancer Res 48: 3221-3229, 1988 .

14. Stahel RA, Gilks WR, Lehmann H-P, Schenker T. Third International Workshop on Lung Tumor and Differentiation Antigens: overview of the results of the central data analysis. Int $J$ Cancer suppl 8: 6-26, 1994.

15. Broers JLV, Klein Rot M, Oostendorp T, Huysmans A, Wagenaar SS, Wiersma-van Tilburg AJM, Vooijs GP, Ramaekers FCS. Immunocytochemical detection of lung cancer heterogeneity usingantibodies to epithelial, neuronal, and neuroendocrine antigens. Cancer Res 47: 3225-3234, 1987

16. Kibbelaar RE, Moolenaar KEC, Michalides RJAM, Van Bodegom PC, Vanderschueren RGJRA, Wagenaar SS, Dingemans KP, Bitter-Suermann D, Dalesio $O$, van Zandwijk N, Mooi WJ. Neural cell adhesion molecule expression, neuroendocrine differentiation and prognosis in lung carcinoma. Eur J Cancer 27: 431-435, 1991.

17. Schol DJ, Mooi WJ, van der Gugten AA, Wagenaar SS, Hilgers J. Monoclonal antibody $123 \mathrm{c} 3$, identifying small cell lung carcinoma phenotype in lung tumours, recognizes mainly, but not exclusively, endocrine and neuron-supporting normal tissues. Int J Cancer suppl 2: 34-40, 1988.

18. Lee $I_{*}$ Gould VE, Moll $R_{n}$ Wiedenmann $B$, Franke WW. Synaptophysin expressed in the bronchopulmonary tract: neuroendocrine cells, neuroepithelial bodies and neuroendocrime neoplasms. Differentiation 34: 115-125, 1987.

19. Loy TS, Darkow GVD, Quesenberry JT. Immunostaining in the diagnosis of pulmonary neuroendocrine carcinomas. An immunohistochemical study with ultrastructural correlations. Am I Surg Pathol 19: 173-182, 1995.

20. De Bruîne AP, Bosman. FT. Neuroendocrine tumours in the respiratory tract. Acta Histoch suppl XXVIII: $99-105,1990$.

21. Jensen SM, Gazdar AF, Cuttitta F, Russell EK, Linnoila RI. A comparison of synaptophysin, chromogranin and L-dopa decarboxylase as markers for neuroendocrine differentiation in lung cancer cell lines. Cancer Res 50: 6068-6074, 1990.

22. Gazdar A, Helman L, Istael M, Russell Ex Linnoila I, Mulshine J, Schuller H, Park J. Expression of neuroendocrine cell markers L-dopa decarboxylase, chromogranin A and dense core granules in human tumors of endocrise and non-endocrine origin. Cancer Res 48: 4078-4082, 1988.

23. Marthy-Ane CH, Costes V, Pujol JL, Alauzen M, Baldet P, Mary H. Carcinoid tumors of the lung: do atypical features require aggressive management? Ann Thorac Surg 59: 78-83, 1995.

24. Linnoila RI, Mulshine JL, Steinberg SM, Funa K, Mathews MJ, Cotelingam JD, Gazdar AF. Neuroendocrine differentiation in endocrine and non-endocrine lung carcinomas. Am Clin Pathol 6: $641-652,1988$.

25. Tötsch M, Müller LC, Hittmair A, Offner D, Gibbs A, Schmid KW. Immunohistochemical demonstration of chromogranins $A$ and $B$ in neuroendocrine tumors of the lung. Hum Pathol 23: $312-316,1992$.

26. Kiriakogiani-Psarapoulou P, Malamou-Mitsi V, Martinopoulou U, Legaki S, Tamvakis $N$, Vrettou E, Fountzilas G, Skarlos D, Kosmidis $\mathbb{P}$, Pavlidis $N$. The value of neuroendocrine markers in non-small cell lung cancer: a comparative immunohistopathologic study. Lung Cancer 11: $353-364,1994$.

27. Mooi WJ, Dewar A, Springall: DR, Polak JM, Addis BJ. Non-small cell lung carcinomass witl. neuroendocrine features. A light microscopic, immunohistochemical and ultrastructural study of 11 cases. Histopathol 13: 329-337, 1988 .

28. Berendsen HH, De Leij L, Poppema $S$, Postmus PE, Boes A, Slüter HJ. Clinical characterization of non small cell lung cancer tumors showing neuroendocrine differentiation features. I Clin Oncol 7: 1614\%]620,1989.

29. Sundaresan V, Reeve JG, Stenning S, Stewart S, Bleehen NM. Neuroendocrine differentiation and clinical behaviour in non-small cell lung tumours. Br I Cancer 64: 333-338, 1991. 
30. Skov BG, Sorengen BJ, Hirseh FR, Larsson LI, Hansen HH. Prognostic impact of histologic demonstration of chromogranin $A$ and neuron-specific enolase in pulmonary adenocarcinoma. Arm Oricol $2: 355-360,199:$.

31. Graziano 5L, Tatum $A H$, Newman NB, Oler A, Kohman LJ, Veil LJ, Gamble GP, Coleman MJ, Barmada $\$$, O Lear $\$$. The prognostic significance of neuroendocrine markers and carcinoembryonic antigen in patients with resected stage I and II non-small cell lung cancer. Cancer kes $54: 22908-2913,1994$.

32. Haimoto $H$, Takahashi $Y$, Koshikawa T, Nagura H, Kato K. Immunohistochemical localization of gamma enolase in normal buman tissues other than nervous and neuroendocrine tissues. Lab Invest 52: $257-263,1985$.

33. Said JW, Vimadalal S, Nash $G$, Shintaku $P$, Heusser RC, Sassoon AF, Lloyd RW. Immunoreactive neuron-specific enolase, bombesin and chromogranin as markers for neuroendocrine lung tumors. Human Pathol 16: 236-240, 1985 .

34. Dardick 1, Rippstein P, Perkins G. Reliability of criteria for ultrastructural identification of neuroendocrine granules. Ultrastruc Pathol 17: 37-47, 1993.

35. Graziano SL, Mazid R, Newman N, Tatum A, Oter A, Mortimer JA, Gullo JJ, DiFino SM, Scalzo AJ. The use of neuroendocrine immunoperoxidase markers to predict chemotherapy response in patients with non-small-cell lung cancer. J Clin Oncol 7: 1398-1406, 1989.

36. Souhami RL. Neuroendocrine phenotype, chemosensitivity and prognosis in adenocarcinoma of the Jung. Ann Oncol 2: 323-324, 1991.

37. Shaw GL, Gazdar AF, Phelps R, Linnoila RI, Ihde DC, Johnson BE, Oie HK, Pass HI, Steinberg SM, Ghosh BC, Walsh TE, Nesbitt JC, Cotelingham JD, Minna JD, Mulshine JL. Individualized chemotherapy for patients with non-small cell lung cancer determined by prospective identification of neuroendocrine markers and in vitro drug sensitivity testing. Cancer Res 53: 5181-5187, 1993. 


\section{SUMMARY}

Neuroendocrine (NE) differentiation can be regarded as the capability of cells to synthesize and secrete a variety of peptide hormones, biogenic amines and related substances, that can play a role in the modulation of, amongst others, growth and differentiation. In recent years numerous studies have emphasized the clinical relevance of NE differentiation in tumors, indicating that carcinomas with NE characteristics have a poorer prognosis as compared to non-NE tumors.

In bronchopulmonary neoplasms a continuous spectrum of tumor types with a NE phenotype can be found. One end of this spectrum is represented by the typical carcinoid tumors, with distinct NE features and good prognosis, while the other end comprises the highly malignant small cell lung carcinomas (SCLCs), with more restricted NE phenotypes. Inbetween these two, tumors with intermediate characteristics in terms of NE features and malignant behaviour can be found. The subgroup of nonSCLC with NE features encompasses an intermediate between SCLC and typical nonSCLC. A major concern in the classification of NE versus non-NE differentiation is the set of criteria used to define this phenotype. Since most markers used for the detection of NE differentiation exhibit either a poor specificity or a restricted sensitivity the use of a panel of NE markers for the diagnosis of tumors is advised. Therefore, the search for new NE markers continues in an attempt to produce immunoreagents that have high sensitivity in addition to a high specificity. The work described in this thesis has aimed at the characterization of a family of NE markers and the production of immunoreagents for their specific detection.

In the first part (chapters 1-4) the neuroendocrine-specific protein (NSP)-gene, transcripts and protein products, the NSP-reticulons are characterized. The second part (chapters 5-7) describes the application of NSP-reticulons as markers for the detection of NE differentiation in lung cancer and the comparison with conventional NE markers.

The antibodies used for the characterization of lung neoplasms have been clustered by the International Workshop on Lung Tumor and Differentiation Antigens. The main aim of this Workshop is to define antigens associated with the different types of lung tumor differentiation and to group the immunoreagents showing similar reactivity patterns. The reagents to the NSP-reticulons comprise cluster-10. In chapter 1 an overview is presented on the characteristics of the NSP transcripts, the NSP-gene encoded proteins and the different antibodies to the NSP-reticulons. The NSP-gene produces three different transcripts with identical $3^{3}$ '-sequences and unique $5^{\prime}$-stretches of variable length. These transcripts encode for three different NSPs, varying in molecular weight between $23 \mathrm{kDa}$ and $135 \mathrm{kDa}$. These NSPs, designated NSP-A (largest product), NSP-B (intermediate size weight products) and NSP-C (smallest product), form clusters that associate with the endoplasmic reticulum (ER), the NSP- 
reticulons.

The biochemical characterization and subcellular localization of the NSP-subtypes, i.e. NSP-A, NSP-B and NSP-C is addressed in chapters 2,3 and 4, respectively. In Western blot analysis of various human, rat and mouse NE cell lines and tissues, NSP$A$ is characterized as a $135 \mathrm{kDa}$ protein, that is post-translationally phosphorylated at serine residues. A similar $135 \mathrm{kDa}$ protein was observed after COS-1 cell transfection with NSP-A cDNA. Immunofluorescence studies of lung cancer cell lines and transfected COS-1 cells revealed an association of NSP-A with the ER, and suggested that the protein accurs as aggregates. These observations were confirmed by double immunofluorescence analysis using antisera to the ER-associated $\mathrm{CA}^{2+}$-ATPase SERCA2 $b$ and by subcellular fractionation experiments, revealing the presence of NSP-A in the microsomal fraction of cells. Gel filtration studies proved that NSP-A forms high molecular weight clusters. Deletion mutants of NSP-A indicate that its carboxy-terminal part, containing two strongly hydrophobic regions, is reponsible for the association with the ER.

NSP-B has so far been found only in the SCLC cell line NCI-H82. Western blot analysis revealed a set of proteins ranging in molecular weight from 35 to $45 \mathrm{kDa}$ af which the largest component is phosphorylated. Proteins of similar molecular weights were detected after immunoprecipitation of COS-1 cells transfected with NSP-B cDNA. As concluded from epitope mapping and 2D-gelelectrophoresis studies, the assumption has been made that the lower protein bands are amino-terminally truncated forms of NSP-B. Gel filtration and immunoaffinity studies revealed that NSP-B can form large supramolecular aggregates, consisting partly of heteropolymers with NSPA. Immunofluorescence and cell fractionation studies of the lung cancer cell line NCIH82 show that also NSP-B is associated with the ER. Immunofluorescence studies of COS- 1 cells transfected with NSP-B cDNA showed that this constituent can interact with the ER as clusters independentlly of NSP-A and NSP-C.

NSP-C has been detected in several NE cell lines as a $23 \mathrm{kDa}$, non-phosphorylated protein. To further characterize NSP-C, a new monoclonal antibody was prepared. Usirng thirs antibody in immunofiurorescence and cell fractronation studies an assoritation of NSP-C with the ER of several lung cancer and neuroblastoma cell lines was observed. A remarkable immunoreactivity of the anti-NSP-C antibody was often present in extensions and growth cones of cells. Immunofluorescence analyses of COS1 cells transfected with NSP-C CDNA, showed that the protein can associate with the ER independently of the other NSPs. Results of immunoprecipitation studies confirm this assumption. Immunohistochemical studies in normal human tissues showed that NSP-C is specifically found in NE tissues, albeit more restricted than NSP-A. On the other hand, a more pronounced expression of NSP-C has been found in neural tissues. The observed differential expression pattern in human tissues is to a certain extent also detected by Western and Northern blotting in several cell lines derived of these tissues. After the characterization of the individual NSP-subunits and the immunoreagents that can be used for their detection, the usefulness of NSPs as markers for NE differentiation in lung cancer diagnosis was investigated. To establish whether or not NSP-detection had an advantage over assays for conventional NE markers, their staining patterns were compared in lung cancer cell lines and in solid lung tumors. First NSP-A was evaluated as a marker for the detection of NE differentiation in lung tumors. Northern blot analysis of human lung carcinoma cell lines showed that NSP.- 
gene expression discriminates between the SCLC and non-SCLC cell lines. When tested for its relationship to the NE phenotype in malignancies and of lung tumors in particular, NSP-A expression was found in the carcinoid tumors, SCLCs, and in a group of non-SCLCs with NE characteristics. It was not found in typical non-SCLCs.

Comparison of NSP expression to the expression patterns of conventional NE markers in cell lines revealed a correlation of NSPs to the presence of other NE features. In cell lines with a low wesicle content NSPs were found, in contrast to the vesicle associated proteins synaptophysin and chromogranin A. NSPs seemed to be more sensitive than these conventional NE markers and the detection of $\mathbf{L}$-dopa decarboxylase activity. A coexpression was found with the neural cell adhesion molecule (NCAM), although not at the single cell level. This study was extended to a series of solid pulmonary meoplasms, including a large group of non-SCLCs. In general, the results of the in vitro studies were confirmed. In carcinoid tumors and SCLC NSP-A and NSP-C expression correlates well with NCAM and synaptophysin. In non-SCLC NSP-A expression was virtually always associated with one or more of the other NE markers. NCAM, however, was found in a broader series of tumors, several of which did not exhibit other NE markers. We conclude that NSPs exhibit a good balance between specificity and sensitivity in the detection of NE differentiation.

These studies indicate that NSP-A and NSP-C may become important markers in the detection of NE differentiation in lung tumors. The question remains whether the applicability of NSP-A antibodies in histopathological diagnosis will be hampered by the recognition of epitopes in macrophages or dendritic cells. A study of NSP-A and NSP-C expression in correlation with clinical behaviour will have to reveal whether these independent NE markers are valuable in terms of prognosis. 


\section{SAMENVATTING}

Cellen met neuroendocriene (NE) differentiatie hebben het vermogen om peptide hormonen, biogene amines en aanverwante substanties te synthetiseren en te secreteren. Deze kunnen een rol spelen bij de beinvloeding van allerlei funkties, waaronder groei en differentiatie. In de afgelopen tijd hebben tal van studies aangetoond dat carcinomen met $\mathrm{NE}$ kenmerken een slechtere prognose bezitten dan dergelijke tumoren zonder NE eigenschappen en daarmee het klinische belang van NE differentiatie benadrukt.

Longkanker omvat een continu spectrum van tumoren met een bepaalde mate van NE differentiatie. Aan een kant van het spectrum treft men de carcinoiden, met uitgesproken $\mathrm{NE}$ kenmerken en goede prognose, terwijl de andere kant de zeer kwaadaardige kleincellige longcarcinomen omvat, met een wat minder uitgesproken NE phenotype. Tussen deze twee in plaatst men tumoren met intermediaire kenmerken voor wat NE eigenschappen en maligniteit betreft. Niet-kleincellige longcarcinomen met NE kenmerken worden histogenetisch geplaatst tussen de kleincellige- en niet-kleincellige longcarcinomen. Van groot belang in de classificatie van NE versus niet-NE differentiatie zijn de criteria die gebruikt worden voor de identificatie van dit phenotype. Omdat de meeste merkers voor de detectie van NE differentiatie niet specifiek of gevoelig genoeg zijn wordt het gebruik van een panel van merkers voor de diagnose van NE tumoren geadviseerd. Daarom ook is blijvend onderzoek nodig naar nieuwe NE merkers die een hoge specificiteit combineren met een hoge gevoeligheid. De studies beschreven in dit proefschrift hebben als doel de karakterisatie van een nieuwe familie van NE merkers en de productie van antistoffen voor hun specifieke detectie.

In het eerste deel (hfst. 1-4) worden de transcripten wan het neuroendocrien-specifieke protein (NSP)-gen en de eiwitprodukten afkomstig daarvan, de NSP-reticulons, gekarakteriseerd. Het tweede gedeelte (hist. 5-7) beschrijft de toepassing van NSPreticulons als merkers voor de detectie van $\mathrm{NE}$ differentiatie in longkanker en de vergelijking met conventionele NE merkers. De antisera die gebruikt worden voor de karakterisatie van longtumoren zijn geclusterd door de "International Workshop on Lung Tumor and Differentiation Antigens". Deze workshops hebben tot doel de longtumor geassocieerde antigenen te definieren en de immunoreagentia met identieke immunoreactiviteit te groeperen. De reagentie tegen de NSP-reticulons omvatten cluster-10. In hoofdstuk 1 wordt cen overzicht gepresenteerd van de kenmerken van de NSP transcripten, van de door het NSP-gen gecodeerde eiwitten en van de verschillende antisera hier tegen. Transcriptie van het NSP-gen leidt tot drie transcripten met identieke 3'-secuenties en unieke 5'-regio's met verschillende lengtes. Deze transcripten coderen voor eiwitten variërend in molecuul gewicht tussen 23 en $135 \mathrm{kDa}$. Deze NSPs, genoemd NSP-A (grootste product), NSP-B (producten met intermediair molecuul gewicht) en NSP-C (kleinste product), vormen clusters die geassocieerd zijn met het endoplasmatisch reticulum (ER), de NSP-reticulons.

De biochemische karakterisering en subcellulaire lokalisatie van de NSP-subtypes, i.e. NSP-A, NSP-B en NSP-C wordt besproken in respectievelijk hoofdstukken 2,3 en 4. 
Met behulp van Western blot analyses van verschillende humane, ratte en muize NE cellijnen en weefsels werd NSP-A gekarakteriseerd als een $135 \mathrm{kDa}$ eiwit, dat posttranslationeel gefosforyleerd wordt op serine residues. Een zelfde $135 \mathrm{kDa}$ eiwit werd aangetoond na transfektie van COS-1 cellen met NSP-A CDNA. Immuunfluorescentie studies van longkankercellijnen en getransfekteerde COS-1 cellen toonden een associatie van NSP-A met het ER aan en suggereerden tevens dat dit eiwit voorkomt als aggregaten. Deze observaties werden bevestigd door dubbellabeling immuunfluorescentie studies met een antilichaam gericht tegen het ER-geassocieerde $\mathrm{CA}^{2+}$ ATPase SERCA2b en door middel van fractioneringsexperimenten, waarbii NSP-A gevonden werd in de microsomale fractie van longkankercellen. Gelfitratie studies bewezen dat NSP-A clusters vormt met een hoog moleculair gewicht. Studies met deletie mutanten van NSP-A toonden aan dat het carboxy-terminale gedeelte, met zijn twee sterk hydrofobe regio's, verantwoordelijk is voor de ER-associatie.

NSP-B is tot nu toe enkel aangetoond in de kleincellige longkankercellijn NCI-H82. Western blot analyse toonde een set eiwitten aan met molecuulgewichten liggend tussen de 35 en $45 \mathrm{kDa}$, waarvan de grootste component gefosforyleerd is. Eiwitten met dezelfde molekuulgewichten werden gevonden na immuunprecipitatie van COS-1. cellen getransfekteerd met NSP-B cDNA. Naar aanleiding van epitoopmapping en 2Dgelelectroforese studies wordt aangenomen dat de lagere eiwitbanden anino-terminaal getrunceerde vormen zijn van NSP-B. Gelfiltratie en immunoaffiniteit studies toonden aan dat NSP-B grote supramoleculaire aggregaten vormt, gedeeltelijk bestaande uit heteropolymeren met NSP-A. Immuunfluorescentie- en celfractioneringsstudies met de longkankercellijn NCI-H82 lieten zien dat NSP-B is geassocieerd met het ER. Immuunfluorescentie studies van COS-1. cellen, getransfekteerd met NSP-B CDNA, maakten duidelijk dat NSP-B als clusters kan associeren met het ER, onafhankelijk van NSP-A en NSP-C.

NSP-C is in verschillende NE cellijnen aangetoond als een $23 \mathrm{kDa}$, ongefosforyleerd eiwit. Een monoclonaal antilichaam werd ontwikkeld om NSP-C verder te karakteriseren. Een associatie van NSP-C met het ER werd met behulp van dit antilichaam in immunfluorescentie- en celfractioneringsstudies van een aantal longkanker- en neuroblastomacellijnen, aangetoond. Een opvallende immuunreacliviteit wordt verder vaak aangetroffen in de uiteinden van cellen. Immunnfluorescentio analyse van COS-1 cellen getransfekteerd met NSP-C CDNA liet zien dat het eiwit onafhankelijk van de andere NSPS kan associeren met het ER in de vorm van aggregaten. Resultaten van immunprecipitatiestudies bevestigden deze aanname. Uit immuunhistochemische studies van normale menselijke weefsels bleek een specifieke expressie van NSP.C in NE weefsels, alhoewel een beperktere expressie werd gevonden in vergelijking tot NSP-A. Een meer uitgesproken NSP-C expressie werd daarentegen gevonden in zenuwweefsels. Deze differentiele expressie in menselijke weefsels werd tot op zekere hoogte ook aangetoond door middel van Western- en Northern blot analyse in verschillende cellijnen afkomstig van deze weefsels.

$\mathrm{Na}$ de karakterisatie van de verschillende NSP-eenheden en de daartegen gerichte antistoffen, werd de waarde van NSPs als merkers voor NE differentiatie in de longkankerdiagnostiek onderzocht. De reactiviteitspatronen van NSP-antistoffen werden vergeleken met die van conventionele NE merkers, zowel in longkankercellijnen als in solide longtumoren, om vast te stellen of NSP-detectie voordelen biedt boven conventionele NE merker detectie. Ten eerste werd NSP-A expressie geëvalueerd als 
een merker woor NE differentiatie in longtumoren. Northern blot analyse van menselijke longkankercellijnen liet zien dat NSP-gen expressie gevonden werd in kleincellige longkankercellijnen en niet in niet-kleincellige longkankercellijnen. Hun relatie tot een $\mathrm{NE}$ phenotype in maligniteiten, en tot NE longtumoren in het bijzonder, werd werder bevestigd doordat NSP-A expressie werd aangetoond in carcinoiden, in kleincellige longcarcinomen en in een groep van niet-kleincellige longcarcinomen met NE kenmerken. In typisch niet-kleincellige longcarcinomen werd geen NSP-A expressie gevonden. Vergelijking van NSP met conventionele NE markers in cellijnen liet een correlatie zien tussen NSPs en de aanwezigheid van andere NE kenmerken. NSPs werden gevonden in cellijnen met weining neuroendocriene granula, in tegenstelling tot de daarmee geassocieerde eiwitten synaptophysine en chromogranine A. NSPs lijken in deze cellijnen dus gevoeligere merkers te zijn dan de conventionele NE merkers en ook de detektie van $\mathrm{L}$-dopa decarboxylase activiteit te overtreffen. Deze studie werd voortgezet in een serie longtumoren, waaronder een grote groep nietkleincellige longcarcinomen. In het algemeen werden de resultaten van de in vitro studies bevestigd. Een hoge mate van coexpressie van NSP-A en NSP-C met synaptophysine en NCAM werd gevonden in carcinoiden en kleincellige longcarcinomen. In niet-kleincellige longtumoren werd NSP-A meestal aangetroffen naast andere NE merkers. NCAM, daarentegen, werd gewonden in een groter aantal nietkleincellige longcarcinomen, alhoewel niet altijd in combinatie met andere $\mathrm{NE}$ merkers. Hieruit werd geconcludeerd dat NSPS een goede balans laten zien tussen specificiteit en sensitiviteit in de detectie van NE differentiatie.

De beschreven studies laten zien dat NSP-A en NSP-C een rol kunnen spelen bij de detectie van NE differentiatie in longtumoren. De vraag of de toepasbaarheid van antiNSP-A antistoffen in de diagnostiek gehinderd zal worden door de herkenning van bepaalde epitopen in macrofagen en dendritische cellen dient nog beantwoord te worden. Een uitgebreide studie naar NSP-A en NSP-C expressie in relatie tot klinisch gedrag zal aangeven of deze onafhankelijke NE merkers van prognostische waarde kumnen zijn. 




\section{COLOR ILLUSTRATIONS}
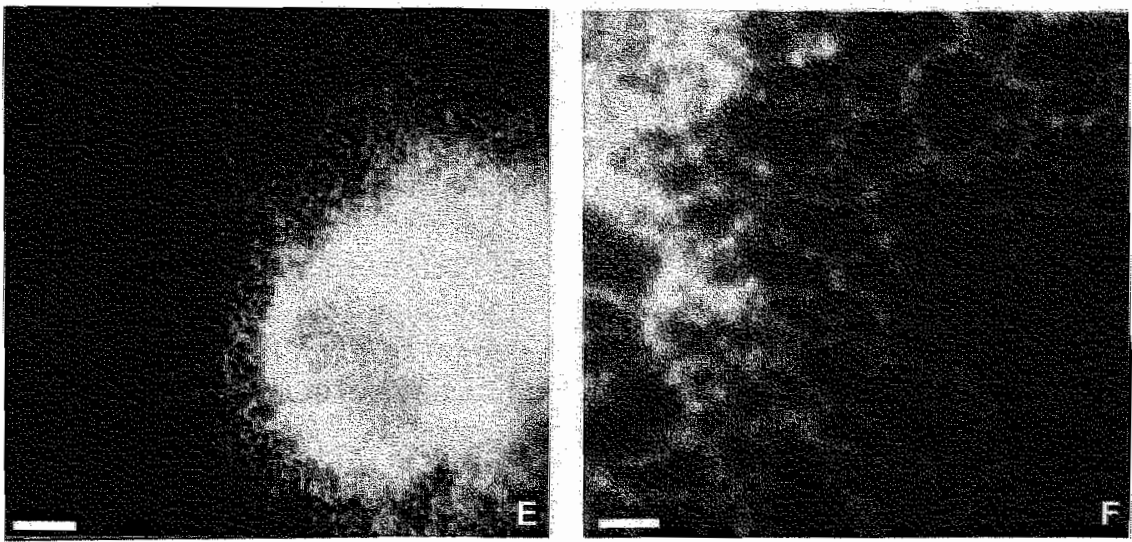

Figs $7 E$ and $7 F$, chapter 2 p. 44
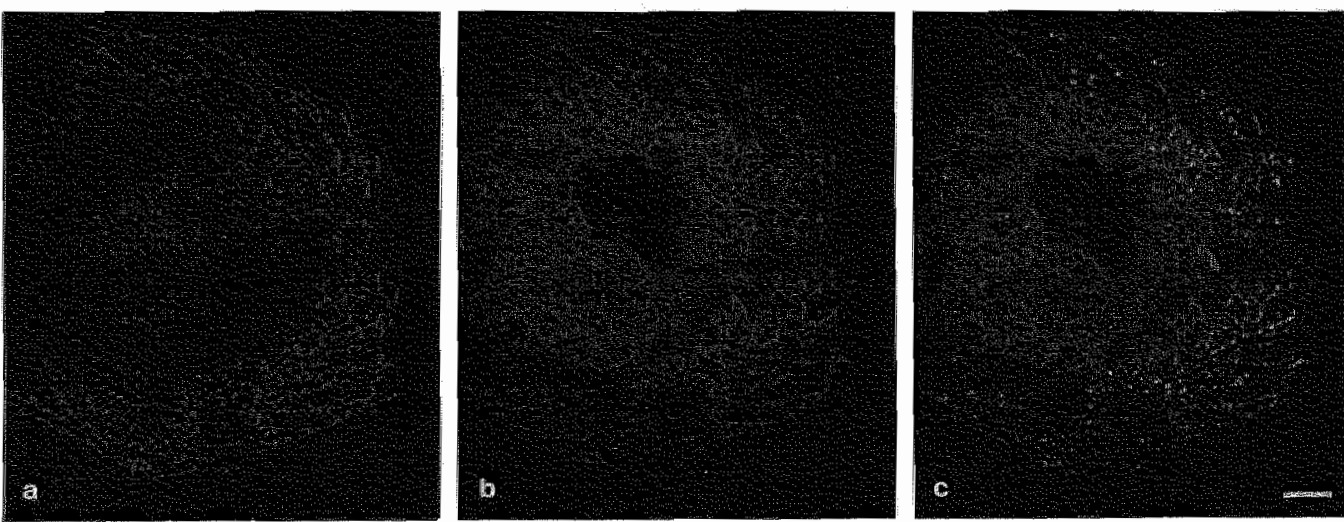

Fig 7 , chapter 3 p. 65

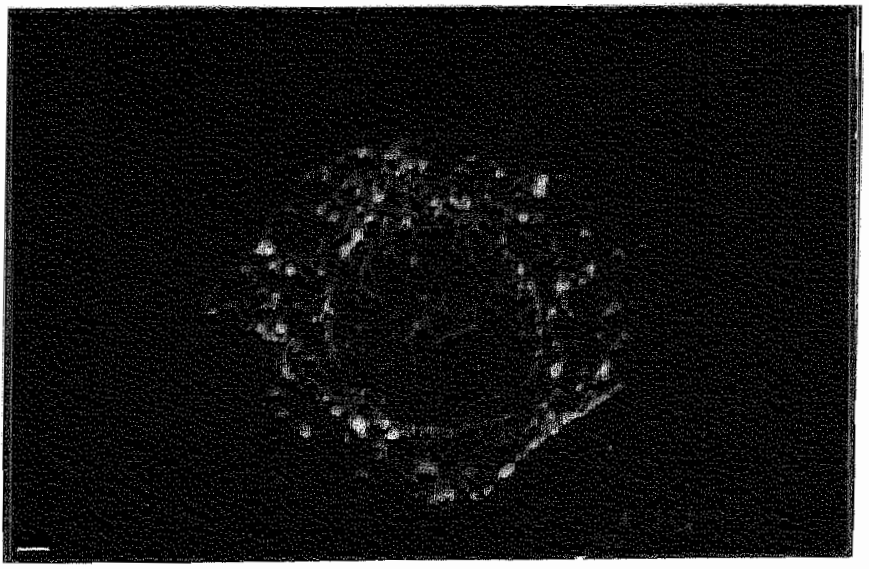

Fig 8, chapter 3 p. 65 

Nicole Hubertina Maria Senden werd op 2 maart 1965 geboren te ValkenburgHouthem. In 1984 behaalde zij het atheneum B diploma aan de scholengemeenschap Stella Maris te Meerssen. In datzelfde jaar begon zij haar studie Biologie aan de Landbouwuniversiteit Wageningen. Het doctoraal examen, met als hoofdvakken Immunologie en Celbiologie (Prof. dr. W.B. van Muiswinkel; Prof. dr. B. Zegers) en bijvak Pathologie (Dr. J. ten Kate), werd behaald in januari 1991. In februari 1991 werd zij aangesteld als AlO bij de vakgroep Moleculaire Celbiologie \& Genetica (Prof. dr. F.C.S. Ramaekers, Dr. J.L.V. Broers) op het door de Nederlandse Kankerbestrijding gefinancierde onderzoek naar NSP-reticulons. Sinds oktober 1995 is zij werkzaam als post-doctoraal onderzoeksmedewerker bij de vakgroep Algemene Heelkunde (Dr. W.A. Buurman) van de Rijksuniversiteit Limburg. 